\title{
Kooperationen in den digitalen Geisteswissenschaften gestalten
}

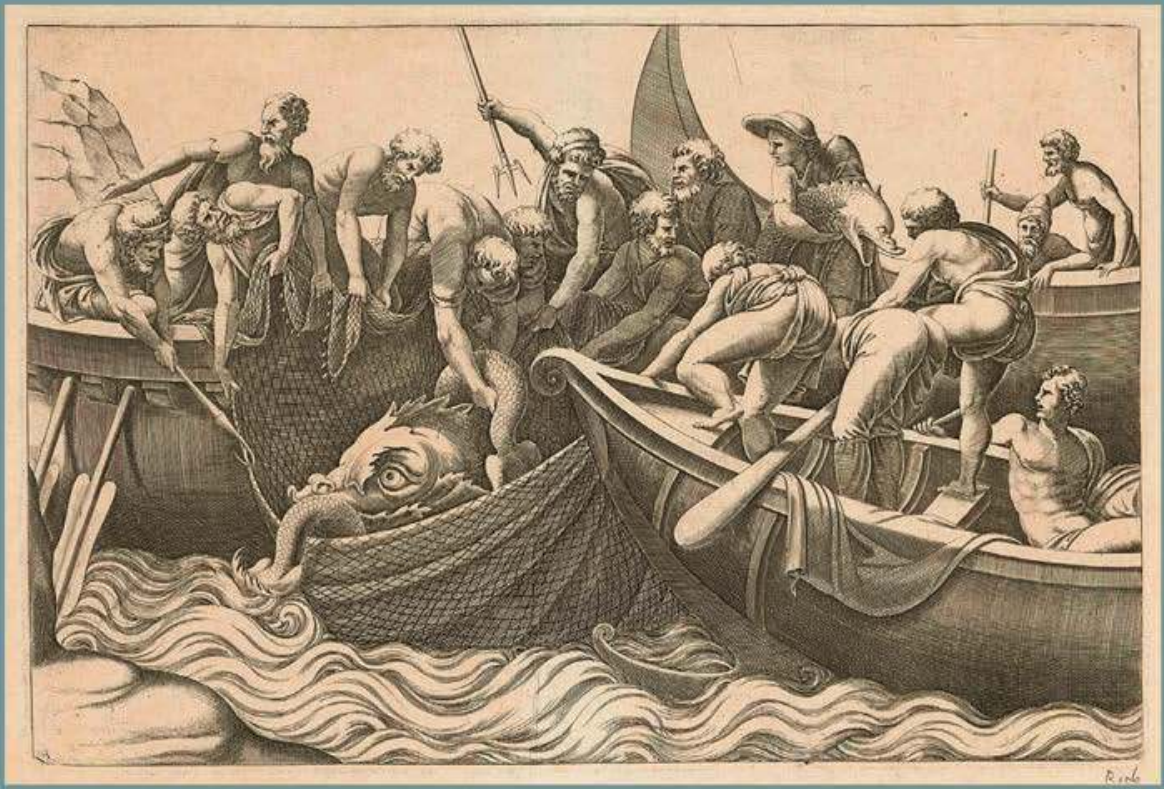

VER unipress 


\section{V\&R unipress}

Open-Access-Publikation im Sinne der CC-Lizenz BY-SA 4.0 (c) 2020, Vandenhoeck \& Ruprecht GmbH \& Co. KG, Göttingen ISBN Print: 9783847111771 - ISBN E-Lib: 9783737011778 


\section{DH\&CS \\ Schriften des Netzwerks für digitale Geisteswissenschaften und Citizen Science}

Band 1

Herausgegeben von

Hendrikje Carius, Martin Prell und René Smolarski 
Hendrikje Carius / Martin Prell /

René Smolarski (Hg.)

\section{Kooperationen in den digitalen Geisteswissenschaften gestalten}

Herausforderungen, Erfahrungen und Perspektiven

Mit 26 Abbildungen

V\&R unipress 
Bibliografische Information der Deutschen Nationalbibliothek Die Deutsche Nationalbibliothek verzeichnet diese Publikation in der Deutschen Nationalbibliografie; detaillierte bibliografische Daten sind im Internet über https://dnb.de abrufbar.

Das Netzwerk für digitale Geisteswissenschaften und Citizen Science wird gefördert durch die Universität Erfurt.

@ 2020, Vandenhoeck \& Ruprecht GmbH \& Co. KG, Theaterstraße 13, D-37073 Göttingen Dieses Werk ist als Open-Access-Publikation im Sinne der Creative-Commons-Lizenz BY-SA International 4.0 („Namensnennung - Weitergabe unter gleichen Bedingungen“) unter dem DOI 10.14220/9783737011778 abzurufen. Um eine Kopie dieser Lizenz zu sehen, besuchen Sie https://creativecommons.org/licenses/by-sa/4.0/.

Jede Verwertung in anderen als den durch diese Lizenz zugelassenen Fällen bedarf der vorherigen schriftlichen Einwilligung des Verlages.

Umschlagabbildung: Reproduktion von Adamo Scultori: Vissers vangen een zeemonster, 16. Jh. (Rijksmuseum Collection, Amsterdam). Quelle: Prometheus-Bildarchiv: https://prometheus.unikoeln.de/en/image/amsterdam_rijksmuseum-1b63c5800cef76ccccefc99ddbf2c7858302b2ef. Dieses Bild wird im Sinne der CC0 1.0 Universal - Public Domain Dedication (http://creativecommons. org/publicdomain/zero/1.0/) verwendet.

\section{Vandenhoeck \& Ruprecht Verlage | www.vandenhoeck-ruprecht-verlage.com}

ISSN $2700-1318$

ISBN 978-3-7370-1177-8 


\section{Inhalt}

Hendrikje Carius / Martin Prell / René Smolarski

Editorial

\section{Aufsätze und Projektvorstellungen}

Michael Kaiser

Beraten, vermitteln, anleiten Das Konzept einer Digitalen Redaktion.

Marina Lemaire / Yvonne Rommelfanger

Einer für alle - Alle für einen. Kooperative und nachhaltige

Softwareentwicklung in FuD-Projekten

Mark Hall

Opportunities and Risks in Digital Humanities Research.

Anna-Rosa Haumann

Die historische Lernspiel-App „Sie heißt jetzt Lotte!“ Chancen,

Probleme und Herausforderungen beim Einsatz digitaler Medien im

Geschichtsunterricht.

Johannes Blavius / Martin Just

Konzeption und Einsatzmöglichkeiten einer Personaldatenbank zur

Aufarbeitung von NS-Verbrechen am Beispiel des

Konzentrationslagerkomplexes Mittelbau-Dora

Christian Oertel / Maximilian Kalus

Historical Network Research and Semantic Graph Databases. The Case

of a Network-Analytical Study on Wenceslaus IV and the Database

Segrada

Marlene Ernst

Salzburg zu Tisch. Wie Citizen Scientists helfen, die barocke Küche zu ergründen

Heinrich Söbke / Andrea Lück

Elementare Interaktionen. Eine web-basierte Methode der multikriteriellen Entscheidungsunterstützung.... 


\section{Berichte und Mitteilungen}

Hendrikje Carius

Virtuelle Ausstellungen. Konzepte, Praxis und Perspektiven. Bericht zu einer Tagungs- und Workshopreihe.....

Christian Oertel

Das Frontend als ,Flaschenhals'? Mediävistische Ressourcen im World

Wide Web und ihre Nutzungspotentiale für eine Digitale

Prosopographie. (19.-21.02.2020, Friedrich-Schiller-Universität Jena).

Oliver Bräckel

Nachruf Patrick Pfeil (17.09.1980-23.12.2019)... 181 


\section{Hendrikje Carius / Martin Prell / René Smolarski}

\section{Editorial}

\section{Einleitung}

Die Publikationsreihe „DH\&CS. Eine Schriftenreihe des Netzwerks für digitale Geisteswissenschaften und Citizen Science" bietet ein Forum für die Vorstellung, Besprechung und kritische Reflektion aktueller Forschungen aus den Bereichen Digital Humanities und Citizen Science. Die Reihe geht aus dem an der Universität Erfurt angesiedelten Netzwerk für digitale Geisteswissenschaften und Citizen Science hervor. Das DH|CS-Netzwerk ist ein Zusammenschluss von Akteurinnen und Akteuren aus den Geisteswissenschaften, der Informatik und bestandshaltenden Institutionen für den interdisziplinären Austausch und die wissenschaftliche Verständigung über Methoden und Standards in den digitalen Geisteswissenschaften sowie insbesondere in Bezug auf die Auswirkungen digital gestützter Forschung auf die epistemologischen Prozesse in den Wissenschaften. Als Veröffentlichung des Netzwerkes gehen die Beiträge vor allem, aber nicht ausschließlich, aus dem Netzwerk und seiner nationalen und internationalen Kooperationspartner hervor. Die Reihe erscheint hybrid als Druckausgabe und als E-Book im Open Access und veröffentlicht Beiträge sowohl in deutscher als auch in englischer Sprache. Die Beiträge im hier vorliegenden ersten Band der Reihe wurden einem Peer-ReviewProzess unterzogen.

Die Schriftenreihe ist der doppelten Ausrichtung des Netzwerkes verpflichtet, das sich sowohl dem Forschungsfeld der Digital Humanities als auch der digitalbasierten Citizen Science widmet. Die Digital Humanities und die Citizen Science werden im Allgemeinen als zwei unabhängig voneinander denkbare und funktionierende wissenschaftliche Zugänge berücksichtigt. Während erstere - als mehr oder weniger exklusive Wissenschafts-Community - mit Hilfe eines technologiegetriebenen Methodenkanons speziell auf die Geisteswissenschaften ausgerichtet sind, bezeichnen letztere eine bestimmte Praxis des Wissens- und schließlich auch Erkenntnisgewinns, die keineswegs diszipli- 
när gebunden ist und einen Akteurskreis einbindet, dessen Partizipationsmöglichkeiten und -voraussetzungen deutlich weniger reglementiert sind. $\mathrm{Ob}$ Klimadatenerhebung, Vogelzählung oder Transkriptionen historischer Quellen, das Einsatzfeld von Bürgerwissenschaftlerinnen und Bürgerwissenschaftlern ist vielfältig. Dabei haben die Citizen Science zuletzt auch einen Aufschwung aufgrund der stetigen Weiterentwicklung vor allem webbasierter Informationstechnologien erfahren, die einen orts- und zeitunabhängigen Zugriff auf Daten und kollaborative Arbeitsumgebungen erlauben. Damit ist schließlich auch ein wichtiges Bindeglied zu den digitalen Geisteswissenschaften benannt. ${ }^{1}$ Diese haben durch den Einsatz immer leistungsfähigerer und rentablerer Informationstechnologien zu einer Transformation der Geisteswissenschaften geführt, die zwar noch keineswegs abgeschlossen ist, dennoch bereits als nachhaltig beurteilt werden kann. Diese Parallele bedeutet aber nicht, dass beide Sphären zwingend miteinander in Beziehung stehen. Es lässt sich sogar konstatieren, dass Digital Humanities und Citizen Science aktuell auffällig unabhängig voneinander agieren. Die Schriftenreihe will nicht zuletzt den Versuch unternehmen, die Ursachen dafür aufzuzeigen und zugleich dazu beitragen beide Domänen stärker aufeinander zu beziehen. Dabei sind eine disziplinäre Offenheit und ein experimentelles Mindset genauso erforderlich wie das Verlassen von gedanklichen Korsetts, die Bürgerwissenschaftlerinnen und -wissenschaftler zum Beispiel als reine Datenlieferanten und Digital Humanists weniger als Partner denn als Dienstleister der sogenannten Fachwissenschaften (im Sinne der althergebrachten wissenschaftlichen Disziplinen) betrachten.

Entscheidend ist, dass beide Sphären einander nicht ausschließen und zusammengedacht neue Möglichkeiten und Wege wissenschaftlicher Erkenntnis ermöglichen. Dies ist eine zentrale Prämisse der Reihe und des Selbstverständnisses des Netzwerkes für digitale Geisteswissenschaften und Citizen Science. Indem sich beide Domänen vor allem durch ein methodisches Umdenken auszeichnen, das wiederum Erkenntnis-Implikationen und (um)strukturierende Folgen für die Wissenschaft(en), ihre Untersuchungsgegenstände, Fragen und Akteure nach sich zieht, bereiten sie den fruchtbaren Boden für Synergien.

1 Vgl. dazu zum Beispiel die Beiträge zum Themenfeld in Kristin Oswald, René Smolarski (Hrsg.): Bürger Künste Wissenschaft. Citizen Science in Kultur und Geisteswissenschaften, Gutenberg 2016; Cord Arendes: Historiker als „Mittler zwischen den Welten“? Produktion, Vermittlung und Rezeption historischen Wissens im Zeichen von Citizen Science und Open Science, in: Heidelberger Jahrbücher Online 2 (2017), S. 19-58. Zur Idee von Citizen Science insbesondere in Abgrenzung zur universitären Professional Science siehe auch Peter Finke: Citizen Science. Das unterschätzte Wissen der Laien, München 2014. 
Wenngleich die Schnitt- aber auch Differenzmengen beider Domänen durch die Schriftenreihe konturiert werden sollen, behandeln nicht alle Beiträge zwingend die digitalen Geisteswissenschaften und die Bürgerwissenschaften. Während einige Beiträge sich gezielt selbst in beiden Domänen verorten, sollen andere die Leserin und den Leser vielmehr zum Weiterdenken und den Versuch des Hinüber-Führens in die jeweils andere Domäne anregen.

\section{Zum Aufbau der Reihe}

Die Reihe bündelt in einem Aufsatzteil Projektvorstellungen und Werkstattberichte, die sich in der Regel an einem zentralen Thema des jeweiligen Bandes orientieren. Der zweite Teil bietet Raum für Tagungsberichte, Ankündigungen und Rezensionen. In diesem Band ist zudem ein Nachruf auf unseren geschätzten Leipziger Kollegen Patrick Pfeil enthalten, der viel zu früh von uns gegangen ist und dem wir damit gedenken möchten.

\section{Band 1: Kooperationen in den digitalen Geisteswissenschaften}

Der erste Band der Schriftenreihe des Netzwerks für digitale Geisteswissenschaften und Citizen Science widmet sich der Frage nach der praktischen Ausgestaltung kooperativer Forschungsprozesse in den Digital Humanities und der Citizen Science im Zusammenspiel von Geisteswissenschaft, Digital $\mathrm{Hu}-$ manities, Informatik und weiteren Akteuren. Die Digital Humanities als disziplinenübergreifendes Forschungsparadigma sind in besonderem Maße von interdisziplinärer Zusammenarbeit geprägt. Diese Zusammenarbeit wird von einer Vielzahl an disziplinen- und projektspezifischen Zugängen, Methoden und Erkenntnisinteressen sowohl aus den Geistes- und Sozialwissenschaften als auch der Informatik auf unterschiedlichste Weise bestimmt. ${ }^{2}$ Die Citizen Science wiederum bedürfen des engen Zusammenwirkens universitärer und außeruniversitärer Wissenschaftlerinnen und Wissenschaftlern zur Erreichung der gemeinsamen Forschungsziele. ${ }^{3}$ In beiden Fällen entstehen aus diesen

2 Vgl. Jennifer Edmonds: Collaboration and Infrastructure, in: Susan Schreibman, Ray Siemens, John Unsworth (Hrsg.): A New Companion to Digital Humanities, Chichester 2015, S. 54-67. doi:10.1002/9781118680605.ch4; Gabriele Griffin, Matt S. Hayler: Collaboration in Digital Humanities Research - Persisting Silences, in: Digital Humanities Quarterly 12.1 (2018). http:// www.digitalhumanities.org/dhq/vol/12/1/000351/000351.html (letzter Zugriff: 09.03.2020). Siehe dort auch eine Differenzierung unterschiedlicher Kollaborationstypen.

3 Siehe hierzu vor allem Lisa Pettibone u.a.: Citizen Science für alle. Eine Handreichung für Citizen Science-Beteiligte, Berlin 2016 und Kristin Oswald, René Smolarski: Einführung: Citi- 
vielfältigen Kooperationsebenen und -formen heraus, neben den anvisierten Synergien, zunächst häufig aber auch zu überwindende Schwierigkeiten. Eine systematische Bearbeitung des Themenfeldes unter Berücksichtigung methodologischer und epistemologischer Aspekte ist noch weitgehend ein Desiderat. ${ }^{4}$ Der hier präsentierte erste Band der Schriftenreihe versammelt vor diesem Hintergrund Beiträge aus unterschiedlichen Bereichen der Digital Humanities und der Citizen Science, in denen die Autorinnen und Autoren aus einer konkreten Projekt- und/oder institutionellen Perspektive heraus einen Blick auf den Aspekt der Kooperation als inhaltliche, organisatorische und forschungspraktische Klammer der beteiligten Partner und ihrer jeweiligen Wissenschafts- und Wissenskulturen richten. Ziel soll es dabei sein, aufzuzeigen, wie Kooperation in einem per se interdisziplinären Umfeld mit verschiedenen methodischen Herangehens- und Arbeitsweisen, Fragestellungen, Wissensmodellierungen, Erwartungen und Zielvorgaben funktionieren kann und welche Erfahrungen damit im jeweiligen Projekt gesammelt wurden. Neben der Diskussion von Spannungsfeldern bei der Ausgestaltung kooperativer Forschungsprozesse liegt ein besonderer Schwerpunkt auf den Erfolgsfaktoren für eine Projektarbeit, in der es gelingt, sich auf die unterschiedlichen (fach)spezifischen und methodischen Ansätze, Arbeits- und Denkweisen des Kooperationspartners einzulassen und in andere Sichtweisen auf das gleiche Projekt einzudenken.

Hier setzt insbesondere der Beitrag von Mark Hall an, der als Basis für erfolgreiche Kollaborationen ein vertieftes gegenseitiges Verständnis von Geisteswissenschaft und Informatik ausführt. Hall widmet sich dazu zunächst grundlegend den Potentialen und Risiken des Einsatzes digitaler Werkzeuge in den Geisteswissenschaften. Er identifiziert dabei vor allem zwei Forschungsfelder, in denen die Digital Humanities eine signifikante Verbesserung des Forschungsprozesses versprechen: Datenzugriff und Datenvolumen. Der Autor sieht aber auch Risiken in der fehlenden methodischen Untermauerung der Digital Humanities, die sich unter anderem in einer ausbleibenden kritischen Analyse der zugrundeliegenden Daten, der Überschätzung von Algorithmen und der fehlenden Evaluation dieser Algorithmen im Hinblick auf ihre Genauigkeit und Korrektheit zeigen. Hall unterstreicht dabei das Risiko eines unre-

zen Science in Kultur und Geisteswissenschaften, in: Dies.: (Hrsg): Bürger Künste Wissenschaft. Citizen Science in Kultur und Geisteswissenschaften, Gutenberg 2016, S. 9-27.

4 Vgl. dazu zum Beispiel Max Kemman: Boundary Practices of Digital Humanities Collaborations, in: Digital Humanities Benelux 1 (2019). http://journal.dhbenelux.org/journal/issues/ 001/Article-Kemman/kemman-main.tex.html oder jüngst die Ausführungen von Frederik Elwert: Digital Humanities - Disziplinen in Konkurrenz oder Kooperation? (20.01.2020). https://belter.hypotheses.org/80 (letzter Zugriff: 09.03.2020). 
flektierten Technik-Optimismus, in den die Digital Humanities als Disziplin solchermaßen abdriften könnten.

Konkreten institutionalisierten Kooperationsmodellen in den Digital $\mathrm{Hu}$ manities widmen sich die Beiträge von Michael Kaiser sowie Marina Lemaire und Yvonne Rommelfanger. So stellt Michael Kaiser ausgehend von einer kritischen Einschätzung des derzeitigen Standes der digitalen Transformation von Forschungsergebnissen der Geisteswissenschaften eine Möglichkeit zur Überwindung der diagnostizierten Spaltung in den Geisteswissenschaften vor. Mit der Digitalen Redaktion als eine organisatorische Schaltstelle, deren Charakteristiken und Aufgaben Kaiser skizziert, soll der Prozess der digitalen Transformation insofern befördert werden, als dadurch Kommunikations- und teils „erhebliche Verständigungsprobleme“ beim Einsatz digitaler Technologien und Methoden in den Geisteswissenschaften aufgefangen werden. Wie projekt- und disziplinübergreifend eine kooperative und nachhaltige Softwareentwicklung für eine größere Forschungscommunity funktionieren kann, zeigen Marina Lemaire und Yvonne Rommelfanger anhand der virtuellen Forschungsumgebung FuD. Als einer der Erfolgsfaktoren sehen die Autorinnen die Leitlinie von $\mathrm{FuD}$, nach der prinzipiell eine Entwicklung für alle konzipiert wird und alle Entwicklungen in nachfolgenden Forschungsvorhaben nachgenutzt werden können. Zentrale Grundlage für eine bedarfsgerechte Entwicklung ist dabei die Zusammenarbeit zwischen Fachwissenschaft und Informatik, die in eine Kooperationsgovernance eingebunden ist. Für den Entwicklungs- und Implementierungsprozess werden Prinzipien der evolutionären Softwareentwicklung und des Design Thinking angewandt, die sich bei der bedarfsgerechten Weiterentwicklung der Forschungsumgebung bewährt haben.

Auf der Ebene eines konkreten Digital-Humanities-Projekts loten Maximilian Kalus und Christian Oertel die Möglichkeiten historischer Netzwerkanalyse mittels der semantischen Graph-Datenbank SEGRADA aus. Als Fallbeispiel dient ihnen dabei das Regentschaftsnetzwerk des als Wenzel der Faule in die Geschichtsbücher eingegangen böhmischen und römisch-deutschen Königs des Hochmittelalters. Die Autoren geben neben einem methodisch-theoretischen Überblick in die Modellierung historischen Wissens mittels Graphen vor allen eine Einschätzung der Vorteile und Herausforderungen, die in der Kombination klassisch historischer Quellenarbeit und softwaregestützter Datenanalyse liegen.

Der Frage von Kooperationen in bzw. der Möglichkeiten einer partizipativen Ausgestaltung von Software für Citizen-Science-Projekte widmen sich die Beiträge von Marlene Ernst sowie Heinrich Söbke und Andrea Lück. Dabei geht Marlene Ernst dem Zusammenspiel zwischen Fachwissenschaftlerinnen 
und Fachwissenschaftlern mit Citizen Scientists am Beispiel des am Zentrum für Gastrosophie des Fachbereichs Geschichte der Universität Salzburg angesiedelten Citizen-Science-Projekts Salzburg zu Tisch nach. Ernst zeigt, mit welchen Strategien eine Kommunikationskultur etabliert wurde, die die Citizen Scientists über die Transkription und Dateneingabe von Texten historischer Kochbuchliteratur in eine Rezeptdatenbank hinaus erfolgreich in das Projekt einbinden konnte. Bereitschaft $\mathrm{zu}$ intensiver Kommunikation und Betreuung durch die Fachwissenschaft, gerade hinsichtlich der digitalen Komponenten, hat sich in der Praxis als einer der Gelingensfaktoren für einen beidseitigen Gewinn aus der Zusammenarbeit erwiesen. Der Beitrag von Heinrich Söbke und Andrea Lück richtet sich demgegenüber auf ein Citizen-ScienceProzesse unterstützendes Softwarekonzept. Sie stellen mit der Multi-Criteria Decision Analysis (MCDA) ein Werkzeug vor, das dabei hilft, Entscheidungsprobleme in komplexen Situationen zu lösen. Der Beitrag verweist auf den Mehrwert von MCDA-Werkzeugen, insbesondere mit Blick auf deren Entwicklung im Rahmen von Citizen-Science-Prozessen. Der komplexen Anforderungen bei partizipativen MCDA-Entwicklungsprozessen kommt das vorgestellte Konzept einer webbasierten Softwareplattform für die Zielsystementwicklung für MCDA-Werkzeuge entgegen. Citizen-Science-Projekte sind insofern als mögliches Anwendungsszenarien denkbar, als den beteiligten Interessengruppen durch kurze Interaktionen (elementare Interaktionen) ein niederschwelliger Zugang zur Plattform und damit zur Beteiligung am Entwicklungsprozess von MCDA-Werkzeugen ermöglicht wird. Kompetenzmodelle steuern dabei die Zusammenarbeit vieler heterogener Teilnehmenden bzw. Citizen Science-Akteure.

Zwei Beiträge, die im Rahmen studentischer Digital-Humanities-Projekte entstanden sind, reflektieren projektspezifische Differenzerfahrungen zwischen Geisteswissenschaft und Informatik und artikulieren den Bedarf an gezielter Vorbereitung auf transdisziplinäres Arbeiten in digitalbasierten Projektzusammenhängen. Johannes Blavius und Martin Just stellen ein Projekt vor, das darauf zielt, prosopographische Daten aus Listen nationalsozialistischen Lagerpersonals mittels einer Datenbank effektiv nutzbar zu machen. Sie schildern ihre Erfahrungen und Herangehensweisen bei der Konzeption und der Umsetzung der Datenbank und stellen mit der Modellierungssprache UML den Einsatz einer digital unterstützten Lösung für die zentrale Herausforderung des Projektes vor. Diese verorten sie in einer adäquaten Kommunikation bedingt durch das komplexe Wechselspiel zwischen Informatik und Geschichtswissenschaft. Im Rahmen eines weiteren studentischen Projekts am Fachbereich Neuere und Zeitgeschichte und Geschichtsdidaktik der Universität Erfurt ist in Zusammenarbeit mit Informatikern der Fachhochschule Erfurt und einem 
Produzententeam von MiriquidiFilm die historische Lernspiel-App Sie heißt jetzt Lotte entstanden, deren Entwicklungsprozess Anna-Rosa Haumann als studentisches Projektmitglied in den Blick nimmt. Als besondere Herausforderungen reflektiert sie die jeweiligen fachspezifischen Kommunikationskulturen und unterschiedlichen Zielvorstellungen bei der Produktentwicklung. Die Umsetzung des Projekts erforderte intensive Kommunikationsprozesse zwischen den Projektbeteiligten. Um für interdisziplinäre DH-Projekte besser vorbereitet zu sein, plädiert Haumann für die systematische Integration informationstechnologischen Kenntniserwerbs in geisteswissenschaftliche Curricula.

Mit den im Band gebündelten Beiträgen und ihren jeweiligen Perspektiven auf das Themenfeld Kooperationen wird nicht der Anspruch verfolgt, das Thema umfassend zu behandeln. Vielmehr bietet der Band Impulse aus konkreten Projektzusammenhängen und trägt somit zur Debatte um die Ausgestaltung kooperativer Forschungsprozesse in Digital-Humanities und CitizenScience-Projekten bei. Die Herausgeber und die Herausgeberin bedanken sich bei der Universität Erfurt für die Unterstützung bei der Drucklegung im Rahmen der Förderung des Netzwerkes für digitale Geisteswissenschaften und Citizen Science als universitärer Forschungsgruppe. Ein herzlicher Dank geht sowohl an die Autorinnen und Autoren als auch die anonymen Gutachterinnen und Gutachter, die zum Entstehen des Bandes beigetragen haben. Zu großem Dank verpflichtet sind wir auch Juliane Wenke für die redaktionelle Unterstützung bei der Erstellung des Bandes. Schließlich sei dem Vandenhoeck \& Ruprecht unipress Verlag für die Aufnahme der Reihe in das Programm gedankt, insbesondere gilt Marie-Carolin Vondracek unser herzlicher Dank für die angenehme Zusammenarbeit.

Die Herausgeber, die Herausgeberin Erfurt, Gotha und Jena im März 2020

\section{Literaturverzeichnis}

Cord Arendes: Historiker als „Mittler zwischen den Welten“? Produktion, Vermittlung und Rezeption historischen Wissens im Zeichen von Citizen Science und Open Science, in: Heidelberger Jahrbücher Online 2 (2017), S. 19-58.

Jennifer Edmonds: Collaboration and Infrastructure, in: Susan Schreibman, Ray Siemens, John Unsworth (Hrsg.): A New Companion to Digital Humanities, Chichester 2015, S. 54-67.

Frederik Elwert: Digital Humanities - Disziplinen in Konkurrenz oder Kooperation? (20.01.2020). https://belter.hypotheses.org/80.

Peter Finke: Citizen Science. Das unterschätzte Wissen der Laien, München 2014. 
Gabriele Griffin, Matt S. Hayler: Collaboration in Digital Humanities Research - Persisting Silences, in: Digital Humanities Quarterly 12.1 (2018) . http://www.digitalhumanities.org/ dhq/vol/12/1/000351/000351.html.

Max Kemman: Boundary Practices of Digital Humanities Collaborations, in: Digital Humanities Benelux 1 (2019). http://journal.dhbenelux.org/journal/issues/ 001/Article-Kem man/kemman-main.tex.html.

Kristin Oswald, René Smolarski (Hrsg.): Bürger Künste Wissenschaft. Citizen Science in Kultur und Geisteswissenschaften, Gutenberg 2016.

Kristin Oswald, René Smolarski: Einführung: Citizen Science in Kultur und Geisteswissenschaften, in: Dies.: (Hrsg): Bürger Künste Wissenschaft. Citizen Science in Kultur und Geisteswissenschaften, Gutenberg 2016, S. 9-27.

Lisa Pettibone u.a.: Citizen Science für alle. Eine Handreichung für Citizen Science-Beteiligte, Berlin 2016. 


\section{Aufsätze und Projektvorstellungen}


Open-Access-Publikation im Sinne der CC-Lizenz BY-SA 4.0 ๑ 2020 , Vandenhoeck \& Ruprecht GmbH \& Co. KG, Göttingen ISBN Print: 9783847111771 - ISBN E-Lib: 9783737011778 
Michael Kaiser

\section{Beraten, vermitteln, anleiten. Das Konzept einer Digitalen Redaktion}

\section{Die steckengebliebene digitale Transformation}

Die digitale Transformation ist in vollem Gange! - ein Satz zu schön, um wahr zu sein. Tatsächlich dauert dieser Prozess nun schon mehr als zehn, vielleicht sogar fast zwanzig Jahre, ohne dass in signifikanter Weise digitale Repräsentationen von Forschungsergebnissen in den Geisteswissenschaften als Standard gelten können. Immer noch gibt es Vorbehalte, immer noch sehen viele den Weg in die Digitalität als Sprung ins Ungewisse: fragwürdig in seiner Nachhaltigkeit und unsicher hinsichtlich der wissenschaftlichen Dividende. Ein Blick zurück auf die Entwicklung der Digital Humanities kann sehr leicht in Larmoyanz münden. Die Euphorie des Anfangs, dass in wenigen Jahren die Geisteswissenschaften ein anderes, digitales Gesicht haben würden, ist jedenfalls längst verflogen.

Aber lässt sich nicht ungeachtet aller Enttäuschungen auch eine Erfolgsgeschichte der digitalen Transformation schreiben? Ohne Zweifel haben sich einige Formate auf neuer medialer Grundlage etabliert, die aus dem geisteswissenschaftlichen Alltagsbetrieb nicht mehr wegzudenken sind. Weit vorangeschritten ist etwa die Retrodigitalisierung von älteren Monographien, ebenso die digitale Bereitstellung von Inkunabeln und alten Drucken, die digitale Aufbereitung von Bibliothekskatalogen, auch die Informationsbeschaffung über Veranstaltungen des WWW, wie es über Homepages, Mailinglisten und RSS-Feeds geschieht. Den Sprung in die Digitalität haben vor allem Rezensionen geschafft, die in relevantem Umfang nur noch digital erscheinen oder zumindest als hybride Publikation. Nicht zu übersehen sind auch Förderstrukturen wie die der Deutschen Forschungsgemeinschaft (DFG) und des Bundesministeriums für Bildung und Forschung (BMBF), die deutliche, wenn auch nicht immer verbindlich verpflichtende, Empfehlungen zu Open Access und somit digitalen Repräsentanzen geben. Von der erkannten Notwendigkeit, 
die Digitalität zu realisieren, zeugen nicht nur nationale Gremien wie der Rat für Informationsinfrastrukturen (RfII) ${ }^{1}$, sondern auch Open-Access-Beauftragte an Universitäten und Forschungseinrichtungen sowie ebendort verabschiedete Open-Access-Strategien; als jüngste Initiative seien noch die Bestrebungen zur Etablierung von Nationalen Forschungsdateninfrastrukturen (NFDI) genannt ${ }^{2}$, die hoffen lassen, dass sich die deutsche Forschungslandschaft an die sich ebenfalls gut entwickelnden europäischen digitalen Forschungsinfrastrukturen anschließen wird.

Wer dies alles als uneingeschränkten Erfolg wertet oder gar als Durchbruch für die digitale Transformation beschreibt, wird schnell Widerspruch erfahren. Denn was den einen bereits als erfolgreiche Implementierung erscheint, sehen andere als Ausweis vielfach gescheiterter Bemühungen. Bislang, so formulieren es die kritischen Stimmen, ist die digitale Transformation nur in kleinen Schritten vorangekommen; Erfolge beschränken sich auf Nebenaspekte, während in wesentlichen Bereichen nach wie vor analoge und eben nicht digitale Formate uneingeschränkt dominieren - dies gilt vor allem für die Monographie, die nicht zuletzt auch karrieretaktisch den wissenschaftlichen Goldstandard in den Geisteswissenschaften darstellt, aber auch für viele Editionsprojekte, die nach wie vor im Druck erscheinen. Bei den Formaten sind viele in den Fachwissenschaften bereits mit PDF-Bereitstellungen zufrieden, während ambitionierte Vertreterinnen und Vertreter der DH sich stattdessen offene Formate wie etwa XML wünschen. Nun kann man sich gerade aus historiographischer Perspektive damit trösten, dass die Gleichzeitigkeit des Ungleichzeitigen ein altbekanntes Phänomen war, ohne dass dadurch der Fortschritt wesentlich gehemmt worden wäre. Auch als schon Zeitungen im Druck erschienen, wurden vielfach noch Nachrichten handschriftlich kopiert und verbreitet, ohne dass damit der Siegeszug des neuen Mediums infrage gestellt worden wäre.

In diesem Fall wird man dennoch vorsichtiger urteilen. Diese unterschiedliche Wahrnehmung der digitalen Transformation ist eben nicht nur einer mal optimistischen und dann einer eher pessimistischen Haltung geschuldet. Vielmehr verweist diese Differenz auf eine grundlegende Spaltung in den Geisteswissenschaften selbst hin. In vielen Fachwissenschaften gibt es eine durchaus positive und offene Einstellung gegenüber den digitalen Möglichkeiten, doch ist bei diesem Change Management eine erstaunlich schnelle Erschöpfung zu konstatieren, insofern man sich schnell mit wenig zufrieden gibt; auf der anderen Seite stehen die Digital Humanists, die mit wachsender Ungeduld auf die

1 Vgl. www.rfii.de (letzter Zugriff: 26.08.2019).

2 Siehe https://www.bmbf.de/de/nationale-forschungsdateninfrastruktur-8299.html (letzter Zugriff: 26.08.2019). 
so wahrgenommene Zögerlichkeit, Gleichgültigkeit und Ablehnung in den Fachdisziplinen reagieren.

Es geht - das sei hier sofort betont - gar nicht um die Verteilung von Schuld an die eine oder andere Seite, sondern lediglich um die Beschreibung der aktuellen Situation. Fernab jeder Wertung bleibt allerdings festzuhalten, dass die konstatierte Spaltung in fachwissenschaftliche Skeptikerinnen und Skeptiker hier und digitale Enthusiastinnen und Enthusiasten dort den Geisteswissenschaften insgesamt schadet. Doch wie lässt sich diese Frontstellung überwinden - und dies in einer Weise, dass niemand als Verliererin und Verlierer dasteht, sondern beide Seiten etwas gewonnen haben? Die digitale Transformation krankt womöglich nicht allein an genuin technischen Unzulänglichkeiten, vielmehr müssen auch andere Komponenten beachtet werden.

Im Folgenden soll daher eine Konstellation beschrieben werden, die versucht, diese für die digitale Transformation ungünstige, teilweise auch spannungsgeladene Situation zu beheben. Die hier vorgestellten Ansätze resultieren aus der Arbeit für perspectivia.net, der Publikationsplattform für die Max Weber Stiftung. ${ }^{3}$ Schwerpunktmäßig stehen bei ihr zunächst digitale Publikationen im Mittelpunkt, doch auch andere Bereiche des weiten Felds der Digital Humanities vom Forschungsdatenmanagement bis hin zur digital gestützten Wissenschaftskommunikation sind hierbei einbezogen. An der Stelle sollen aber nicht die technischen Grundlagen vorgestellt werden. Vielmehr geht es im Kern um eine organisatorische Komponente, die helfen soll, Kommunikationsund Verständnisprobleme und daraus resultierende Missverständnisse beim Einsatz digitaler Technologien und Methoden in den Geisteswissenschaften aufzufangen. Wir sprechen seit einigen Jahren von der Digitalen Redaktion als der organisatorischen Schaltstelle, die in entscheidender Weise den Prozess der digitalen Transformation befördern kann. In aller Ehrlichkeit müssen wir dabei feststellen, dass es sich um einen Versuch handelt, dessen letzte Ergebnisse immer noch offen sind. ${ }^{4}$ Doch die bislang gemachten Erfahrungen nähren die Hoffnung, auf diese Weise dem Ziel einer in den geisteswissenschaftlichen Fächern erfolgreich implementierten Digitalität wesentlich näher zu kommen.

3 Siehe https://www.perspectivia.net (letzter Zugriff: 26.08.2019).

4 Die Entwicklung bei perspectivia.net kurz beschrieben bei Katrin Neumann und Fabian Cremer: Stolz und Vorurteil. Geisteswissenschaften und Open Access in einer Dekade perspectivia. net, in: Digitale Redaktion, 03.05.2018. https://editorial.hypotheses.org/147, sowie dies.: Zurück in die Zukunft II - keine erweiterten Publikationen in den Geisteswissenschaften?, in: Digitale Redaktion, 18.07.2018. https://editorial.hypotheses.org/231 (letzter Zugriff: 26.08.2019). 


\section{Die Ambiguitäten der Digitalität}

Der Weg in die Digitalität bedeutet grundsätzlich eine größere Freiheit. Viele Vorentscheidungen und Beschränkungen im analogen Medium sind hier aufgehoben. Diese gewonnene Freiheit bietet also neue Spielräume, die wiederum gestaltet werden müssen. Doch wer tut dies und auf der Grundlage welcher Kompetenz?

Wer also digital publizieren oder digitale Forschungsdaten generieren möchte, wird nicht nur viele Parameter in diesem Projekt selbst festzulegen haben, sondern sie und er sieht sich als Fachwissenschaftler auch in der Verantwortung dafür. Was zunächst als Freiheit und als Selbstermächtigung erscheint, wird schnell zur Bürde einer Verantwortung, die nur schwer erträglich scheint. Denn die Expertise zur Beantwortung dieser offenen Punkte bringt ein Fachwissenschaftler meist nicht oder in nicht genügendem Maße mit.

Naheliegend ist, dass nun von fachwissenschaftlicher Seite die Anforderungen formuliert werden, die für das eigene digitale Projekt notwendig sind. Von der IT- und DH-Seite werden diese Wünsche daraufhin aufgenommen und entsprechend wird eine technische Lösung aufgesetzt. Allerdings existiert diese klare und eindimensionale Rollenverteilung oft genug nur in der Theorie. Denn tatsächlich gibt es erhebliche Verständigungsprobleme zwischen den Nur-Wissenschaftlerinnen und Wissenschaftlern und den Nur-Technikerinnen und Technikern - erstere wissen oftmals viel zu wenig um die Möglichkeiten, aber auch die Beschränkungen dessen, was technisch möglich ist. Letztere haben mitunter erhebliche Wissenslücken, was die Erfordernisse des wissenschaftlichen Arbeitens ausmacht. Handelt es sich also nur um fehlendes Wissen auf beiden Seiten? Würden also entsprechende Aufklärung und weitere Schulung dieses Manko ausgleichen? Tatsächlich liegt das Problem tiefer und ist am Ende in wissenschaftsimmanenten Strukturen verankert.

Wer sich in einer Fachwissenschaft engagiert, will eigentlich mehr oder weniger ausschließlich der eigenen Forschung nachgehen. Doch diesem Drang kann er oder sie in dem Moment nicht uneingeschränkt nachgeben, da die Offenheit der digitalen Transformation ihn oder sie mit anderen noch zu klärenden Fragen konfrontiert. Erschwerend kommt hinzu, dass die Relevanz dieser Punkte grundsätzlich akzeptiert wird, dabei aber zumindest stillschweigend hingenommen werden muss, dass diese Fragen die eigene Kompetenz sehr schnell übersteigen.

Wenn also die DH-Seite die Frage „Was benötigt dieses Projekt an IT-/DHServices?" stellt, wird dieser Zwiespalt manifest. Die fachwissenschaftliche Seite honoriert in diesem Moment oftmals kaum die prinzipielle Offenheit und Gestaltbarkeit der Situation. Deutlich häufiger wird diese Nachfrage als Provo- 
kation, ja als Kampfansage wahrgenommen und missverstanden. Ab jetzt muss sich eine Forschende und ein Forschender mit Aspekten des Projekts auseinandersetzen, die ihr und ihm deutlich weniger geläufig sind als der wissenschaftliche Kernauftrag.

Indem sie und er auf kaum vertrautem Terrain unterwegs ist, gerät auch die eigene Autonomie als Forschende und Forschender in Gefahr. Sie droht nun durch Fremdexpertise beschnitten zu werden. Wenn diese Wahrnehmung eskaliert, geht es nicht mehr nur darum, welche Programme und Techniken eingesetzt werden, sondern letztlich darum, wer die Oberhoheit über das wissenschaftliche Projekt innehat. Wie kann in dieser Situation noch eine prinzipielle Bereitschaft gedeihen, sich den Chancen der digitalen Transformation zuzuwenden, wenn die Vorteile gar nicht wirklich sichtbar werden, wohl aber eine Projektkonzeption aufgetischt wird, die scheinbar weit weg von der fachdisziplinären Ausgangsfrage führt?

Natürlich ist es so, wie gerade geschildert, keine zwangsläufige Tendenz für ein digital aufgesetztes Projekt, und man darf diese Konstellation auch nicht dramatisieren. Die Erfahrung zeigt jedoch, dass hier ein kritischer Moment erreicht wird, aus dem eine echte Belastung für die Kooperation der verschiedenen Stakeholder erwachsen kann.

\section{Die Digitale Redaktion als Zwischeninstanz}

An diesem potentiell schwierigen Punkt kommt die Digitale Redaktion zum Einsatz. Um es gleich vorneweg zu nehmen: Sie ist keineswegs ein Garant dafür, dass ein Projekt für eine digitale Publikation oder Edition auf jeden Fall ein Erfolg wird. Ihr kommen grundsätzlich zwei Funktionen zu, mit deren Hilfe ein digitales Projekt organisatorisch stabilisiert werden kann; für die Projektleitung ist dies dann doch eine wesentliche Voraussetzung für die angestrebte Zielsetzung, nämlich eine angemessene technische Realisierung zu erreichen. ${ }^{5}$

Die erste Funktion besteht darin, dass die Digitale Redaktion als ein Puffer wirkt und somit einen Effekt hat, wie er für praktisch jede Zwischeninstanz angenommen werden kann. Die direkte Konfrontation - um es dann doch einmal dramatisch zu formulieren - zwischen fachdisziplinär Forschenden und der IT, der DH und den Bibliothekarinnen und Bibliothekaren / Informationswissenschaftlerinnen und -wissenschaftlern wird vermieden. Die Digitale Redaktion ist Botin zwischen diesen Parteien und vermittelt Lösungsangebote

5 In eine ähnliche Richtung denkt auch schon Jennifer Edmonds: Collaboration and Infrastructure, in: Susan Schreibman, Ray Siemens, John Unsworth (Hrsg.): A New Companion to Digital Humanities, Chichester 2015, S. 54-67. doi:10.1002/9781118680605.ch4. 
an die Fachdisziplinen und umgekehrt Bedarfsvorstellungen an die Spezialistinnen und Spezialisten im Projekt.

Doch warum soll dies der Digitalen Redaktion besser gelingen als den anderen Projektbeteiligten? Die Antwort darauf liegt in dem einfachen Umstand, dass die Digitale Redaktion keine eigene Agenda in diesem Projekt hat - außer dem Projekt selbst. Alle anderen Akteure sind Stakeholder, die eigene Vorstellungen, manchmal eher diffus und wenig artikuliert, mitunter sehr dezidiert und geschliffen, vertreten. Mit dieser eigenen Agenda geht ein Expertentum einher, das möglicherweise nur noch wenig Raum für echte Empathie lässt oder den anderen Akteuren gar Teilhabe einzuräumen bereit ist.

Welche zentrale Rolle Anmerkungen für geisteswissenschaftliche Publikationen spielen und dass deswegen die Positionierung, die gute Sichtbarkeit, das schnelle Navigieren im Anmerkungsapparat und auch der Wechsel von Text zu Fußnoten von immenser Bedeutung ist und deswegen entsprechende Entwicklungsressourcen bindet, ist nicht immer jeder Programmierexpertin und jedem Programmierexperten bewusst. Umgekehrt fehlt seitens der Fachwissenschaft oftmals das Verständnis für die Funktionsweise digitaler Repräsentationsformen. In vielen Fällen denken Geisteswissenschaftlerinnen und -wissenschaftler in den traditionellen Publikationsformen, wollen mithin die gewohnten und vertrauten Eigenschaften eines Buches einfach nur ins digitale Medium transponieren - dass dieses andere Möglichkeiten hat und anders funktioniert, wird oft nicht gesehen (oder auch anerkannt). Aus diesem Unverständnis resultiert am Ende Enttäuschung auf Seiten der Fachdisziplin, weil die digitale Repräsentanz vertraute Erscheinungsformen nicht mehr bietet. Dass dagegen neue Präsentationsformen und Aufbereitungen qualitative Vorteile bieten, wird in diesem Moment nicht selten übersehen.

Umgekehrt besteht bei DH-Begeisterten die Gefahr, dass sie für Lösungen werben, die zwar die neuen medialen Möglichkeiten ausschöpfen, dabei aber völlig an den Bedarfen der Fachwissenschaft vorbei konzipieren. Ein typisches Beispiel ist die graphische Umsetzung und Auswertung von erhobenen Daten. Ohne Zweifel ist es faszinierend zu sehen, wie sich etwa Korrespondentennetzwerke - die Edition von Briefen gehört sicher zum häufigsten Typus von Datenbankprojekten - auf eine Landkarte visualisieren lassen. Auch in der Fachwissenschaft finden solche Anwendungen immer wieder Anklang. Was bislang wenig aufgegriffen wird, ist die Frage, welchem Erkenntnisinteresse diese visuelle Umsetzung Rechnung trägt, mithin welches fachwissenschaftliche Problem sich damit lösen lässt. Die Digital Humanities bieten hier Antworten auf Fragen, die die Fachwissenschaft nie gestellt hat. Dass beide Seiten aneinander vorbei geredet und konzipiert haben, ist schlimm genug; hinzu 
kommt aber, dass auch Ressourcen hierfür aufgewandt wurden, die andernorts fehlen.

Schlimmstenfalls entspinnt sich ein Konflikt um die Deutungshoheit im Projekt. Dieser droht dann, wenn sich die beteiligten Seiten vom Gegenüber nur mindermäßig wertgeschätzt fühlen. Hier muss gar nicht böser Wille im Spiel sein, es reicht das Unverständnis und die mangelnde Einsicht in die Arbeitsweise und das Selbstverständnis der jeweils anderen. Dass etwa Digital Humanists keineswegs nur wohlfeile Erfüllungsgehilfen im Kontext geisteswissenschaftlicher Projekte sind, sondern durchaus eine eigenständige Wissenschaft vertreten, die eigene Fragestellungen und Methoden entwickelt, wird von den klassischen Geisteswissenschaften immer noch einmal übersehen ein Verhalten, das die Projektkommunikation belasten kann.

Es geht nun nicht darum, diese Konstellation als unmittelbar konfliktträchtig darzustellen; wohl aber treffen unterschiedliche wissenschaftliche Ansätze aufeinander, die abgestimmt und in Einklang zueinander gebracht werden sollten. Letztlich geht es um eine Professionalisierung im Austausch über Wünsche der Fachdisziplinen einerseits und Angebote der DH, IT und Informationswissenschaften andererseits.

Die zweite Funktion der Digitalen Redaktion ist hingegen die eines Sündenbocks. Projekte der digitalen Transformation sind durchweg so komplex, dass - wie schon angesprochen - ganz unterschiedliche Disziplinen und Expertinnen und Experten aufeinandertreffen und kooperieren müssen. Fernab aller realen technischen Herausforderungen wird man den menschlichen Faktor nie ganz ausklammern können. Fehlgeleitete Erwartungen, echte Missverständnisse und tatsächlich unvorhergesehene Missgeschicke im Projektverlauf lösen auf allen Seiten Verdruss aus und können die Zusammenarbeit belasten.

Die oben angesprochene umkämpfte Deutungshoheit im Projekt und die damit verbundene Frage nach Projekthierarchien schlagen in dieser Situation schnell um in die Suche nach einer verantwortlichen Instanz für die missliche Lage. Formale Projektleitung, die generell (und sicher zu Recht) bei der fachwissenschaftlichen Seite liegt, steht dann gegen eine Sonderexpertise von IT und $\mathrm{DH}$, die offenbar versagt hat. In dieser verkanteten Situation ist es überaus hilfreich, eine strukturell schuldige Instanz zu haben: dies ist die zweite, vielleicht sogar noch bedeutsamere Rolle der Digitalen Redaktion.

Sie kann diese Rolle übernehmen, eben weil sie keine genuin eigenen Interessen hat. Gleichwohl hat sie aber mit allen Beteiligten in Kontakt gestanden und die Entscheidungsprozesse über den Einsatz bestimmter Techniken und Projektschritte maßgeblich vermittelt und womöglich angeleitet. Hat sie dadurch tatsächlich Verantwortung in diesem Projektmanagement? 
Hier wird man Parallelen in betriebswirtschaftlichen Szenarien finden, in denen schwierige Entscheidungen nicht von den Repräsentanten des Unternehmens selbst getroffen werden, sondern einer externen Instanz überlassen werden. ${ }^{6}$ In dem Fall empfiehlt eine Unternehmensberatung eine Lösung, die für verschiedene Stakeholder im Unternehmen schwierig ist, und übernimmt gleichzeitig die Rolle des ,Buhmannes - da das Management das eigene Handeln mit einer Empfehlung von außen begründet, bleibt auch das Odium einer als unliebsam wahrgenommenen Entscheidung extern und belastet die Atmosphäre innerhalb des Unternehmens deutlich weniger. Doch handelt es sich hier wirklich um eine nach betriebswissenschaftlichen Kategorien zu bezeichnende „Führungssubstitution“, nach der die Digitale Redaktion in das Dilemma einer sogenannten „Beratungsperlusion“ hineinrutscht, weil die eigentlichen Projektverantwortlichen zu viel Verantwortung abgetreten haben?

Tatsächlich wird man immer im Einzelfall zu entscheiden haben, wie viel Entscheidungskompetenz die meist fachdisziplinäre Projektleitung de facto an die Digitale Redaktion abgetreten hat. Als Maklerin zwischen den Stakeholdern des Projekts übernimmt sie aber immer einen Teil von Verantwortung. Entscheidend ist, dass sie sowohl gegenüber den Fachwissenschaftlerinnen und -wissenschaftlern als auch der IT, den DH-Beteiligten und Informationswissenschaftlerinnen und -wissenschaftlern als Instanz auftritt, die eine im Nachhinein als problematisch empfundene Entscheidung vermittelt hat. Damit übernimmt sie als Mittlerin automatisch eine Sündenbockfunktion. Unabhängig von tatsächlichen Schuldfragen ermöglicht diese Rolle der Digitalen Redaktion den eigentlichen Stakeholdern des Projekts, das Gesicht zu wahren und miteinander unbeschädigt weiterzuarbeiten. Die Erfahrung zeigt, dass sich die Projektbeteiligten dieser besonderen Funktion der Digitalen Redaktion auch unausgesprochen durchaus bewusst sind. Da sie ohnehin im Zentrum der Kritik steht, kann sie sich letztlich auch über die Schuldfrage, die sowieso wenig für den Projektfortschritt beiträgt, hinwegsetzen und sich der deutlich bedeutenderen Frage nach den Ursachen für die momentan problematische Projektentwicklung zuwenden.

6 Dazu etwa Ulrich Hagenmeyer: Integrative Unternehmensberatungsethik: Grundlagen einer professionellen Managementberatung jenseits reiner betriebswirtschaftlicher Logik, in: Zeitschrift für Wirtschafts- und Unternehmensethik 3 (2002) 3, S. 356-377, bes. 365 und 368. https://nbn-resolving.org/urn:nbn:de:0168-ssoar-347679 (letzter Zugriff: 26.08.2019). 


\section{Aufgaben der Digitalen Redaktion}

Mit diesem Szenario ist der Krisenfall angesprochen, der in jedem Projekt möglich ist, aber eben nicht notwendigerweise auftreten muss. Vielfach kommt es gar nicht dazu, eben weil die Digitale Redaktion von Anfang an in die Konzipierung eines Publikations- oder Editionsvorhabens direkt eingebunden ist: Alle Stakeholder wurden von ihr frühzeitig involviert, so dass Aufgaben und Rollen zugewiesen und Lösungen entsprechend verabredet und dann auch implementiert werden konnten. In einer solchen Konstellation lassen sich Projektverläufe mit guten Aussichten erfolgreich gestalten. Aber welche konkreten Aufgaben sind es, die der Digitalen Redaktion zufallen?

Als erstes sei hier die Beratungsfunktion im Sinne einer tatsächlichen Bereitstellung von Expertise genannt. Sie ergibt sich aus der Mittlerrolle. In erster Linie benötigt die fachdisziplinäre Projektgruppe diese Beratung, idealerweise gleich von der Konzipierung der Projektidee an. Auch die aktive Teilnahme an der möglichen Drittmittelakquise ist hier von wachsender Bedeutung. Wie die digitalen Komponenten später aussehen werden, kann zusammen mit der Digitalen Redaktion bereits in der Phase der Projektbeantragung konzipiert werden.

Beratung allein hilft in vielen Fällen nicht. Zu eruieren, welche IT- und DHWerkzeuge tatsächlich sinnvoll auszuwählen sind, bedarf immer wieder entsprechender Testdurchläufe. Eine entsprechende Umgebung mit Projektteilnehmenden zu bespielen, hat sich als wichtiger Schritt etabliert, um mit geringen Aufwänden zu ermitteln, wo tatsächlich Bedarfe sind und wie sie sich im Projektverlauf entwickeln können. Das setzt voraus, dass die Digitale Redaktion auch in das Projektmanagement involviert ist und alle Projektschritte mitbegleitet und evaluiert. Eine Rückmeldung an die beteiligten Projektpartnerinnen und -partner stabilisiert den Fortgang im Verlauf der Arbeit und stellt sicher, dass alle Stakeholder Schritt halten. Je nach Komplexität und Spektrum der DH-Anwendungen sind Schulungen wichtig, gerade wenn im Projektverlauf auf fachdisziplinärer Seite eine stärkere personelle Fluktuation zu beobachten ist. Allerdings sind die Aufgaben zeit- und personalintensiv. ${ }^{7}$

Nicht zu vergessen sind Aufgaben, die nach der eigentlichen Projektphase liegen. Das bedeutet meist nicht, dass alle wissenschaftlichen Arbeiten schon abgeschlossen sind, wohl aber hören projektbasierte Finanzierungen auf. Was

7 Wie wichtig Schulungen und der generelle Austausch zwischen den verschiedenen Stakeholdern sind, bestätigen die Erfahrungen der Digitalen Redaktion in der Arbeit für perspectivia.net. Vgl. dazu den Bericht von Fabian Cremer u. a.: Ein stiftungsweiter Workshop zum Digitalen Publizieren, in: Digitale Redaktion, 06.05.2019. https://editorial.hypotheses.org/548 (letzter Zugriff: 26.08.2019). 
eine stetige Aufgabe bleibt, ist die Kuratierung der Projektergebnisse. Dieses life cycle management, das von einfachen Updates der eingesetzten IT über die Ergänzungen und Verbesserungen der Forschungsdaten bis hin zu deren Migration auf neuere Programmversionen reicht, stellt eine Aufgabe dar, die gerade von fachwissenschaftlicher Seite oft unterschätzt wird. Man kann dies den am Projekt involvierten Forschenden kaum übelnehmen, wenn sie selbst, wie das Wissenschaftssystem es so anlegt, nur über projektfinanzierte Stellen verfügen. Umso wichtiger bleibt es, dass mit der Digitalen Redaktion eine Instanz vorhanden ist, die von der Entwicklung der Projektidee über den Projektverlauf bis hin zur dauerhaften Nachsorge der Wissenschaftsergebnisse mit dem Forschungsunternehmen verbunden bleibt.

Bislang haben wir bei der Aufgabenbeschreibung stets auf die Mittlerfunktion zwischen der Fachwissenschaft einerseits und der IT und den Digital Humanities andererseits abgehoben. Hinzu kommt, wie auch oben schon erwähnt, die Einbindung informations- und bibliothekswissenschaftliche Expertise (siehe Abbildung 1). An der Stelle sei noch angefügt, dass sich auch eine Rückbindung an die Leitung der jeweiligen Institution, an der das jeweilige Projekt angesiedelt ist, als sinnvoll erwiesen hat. Dies gilt ebenso für die jeweilige Verwaltung. Gerade hier kann die Digitale Redaktion ihre Mittlerfunktion sinnvoll wahrnehmen, wenn es um die Erläuterung von finanziellen Aufwänden für die Bereitstellung von notwendigen IT- und DH-Anwendungen geht.

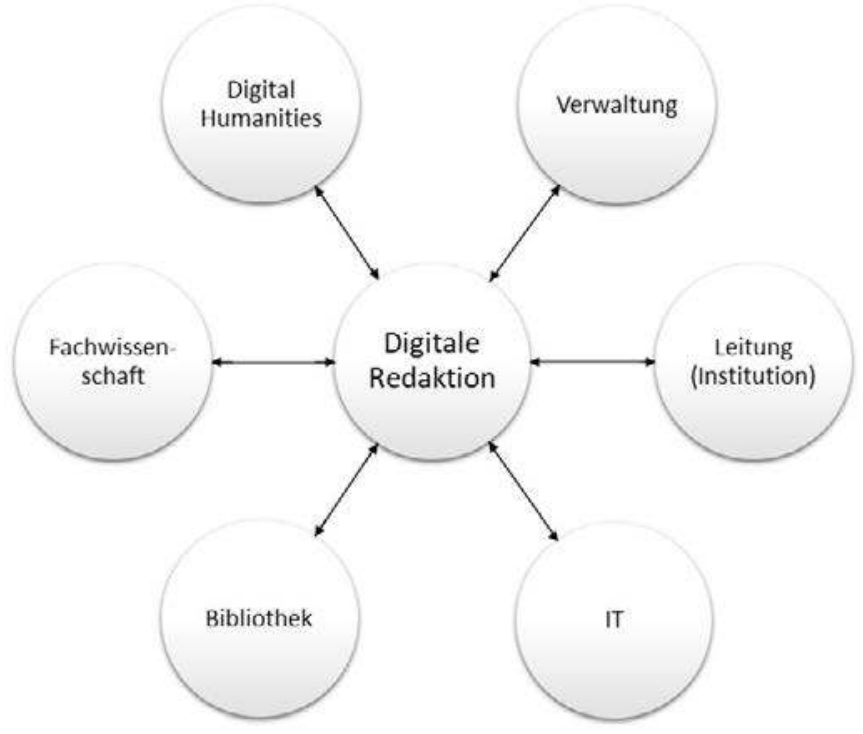

Abbildung 1: Die Digitale Redaktion inmitten der verschiedenen Stakeholder. 
Wenn bis jetzt viel von den Aufgaben und dabei auch den durchaus hohen Anforderungen an die Digitale Redaktion die Rede war, soll an der Stelle kurz das Echo zur Sprache kommen, das es für diese Arbeit gibt. Oder als Frage formuliert: Wie sieht es mit der Reputation für die Digitale Redaktion aus? Im Projektkontext wird sicherlich anerkennend wahrgenommen, welche Leistungen durch sie für den Projektfortschritt erzielt werden. Nach außen hin tritt die Digitale Redaktion eher zurückhaltend auf. Dies ist bedingt durch ihre Vermittlungsfunktion, ebenso ist diese tendenzielle Zurückhaltung eine Voraussetzung für die mediative Leistung. Wenn im Bereich der Digital Humanities ohnehin über mangelnde Akzeptanz und Wertschätzung diskutiert wird sowie über das Manko an Reputation für das Engagement im digitalen Bereich, so gilt dies erst recht für die Digitale Redaktion - doch dies liegt vor allem an ihrer strukturellen Aufgabe im Projektbereich.

\section{Das Profil der Digitalen Redaktion}

Wenn eine Digitale Redaktion als intermediäre Instanz eine wichtige Rolle im Prozess der digitalen Transformation spielen soll, stellt sich die Frage nach dem Profil ihrer Mitglieder. Am Ende soll daher kurz skizziert werden, welche Eigenschaften von besonderer Bedeutung sind. Bezüglich der Ausbildung wird man in jedem Fall die fachwissenschaftliche Verortung in einer geisteswissenschaftlichen Disziplin voraussetzen müssen. Nachvollziehen zu können, wie ein bestimmtes Fach funktioniert und welche Spezifika eine jeweilige Fachkultur auszeichnet, ja überhaupt das Gespür dafür zu bekommen, dass es diese gibt und dass sie Selbstverständnis wie Arbeitsweise in diesen Fächern prägt, ist zentral. Erst dieses Verständnis wird auch eine adäquate Umsetzung der durchaus traditionellen Redaktionstätigkeit ermöglichen.

Gleichwertig zu einer fachwissenschaftlichen Ausbildung sind aber die Kenntnisse im Bereich der Digital Humanities zu veranschlagen, beginnend von Webtechnologien und Softwarearchitekturen bis hin $\mathrm{zu}$ mindestens Grundkenntnissen in gängigen Programmiersprachen. Diese Grundlagen werden sicher in den sich heute schon gut entwickelnden Studiengängen der Digital Humanities vermittelt. Von großer Bedeutung bleiben Erfahrungen im Praxisbereich, vor allem also konkrete Projekterfahrungen.

Spätestens über diese anwendungsorientierten Erfahrungen wird jedem Mitglied einer Digitalen Redaktion auch bewusst werden, dass zusätzlich zu handfesten Sachkenntnissen auch Soft Skills und eine bestimmte Einstellung essentiell ist. Diese ist in erster Stelle gekennzeichnet vom Servicegedanken: eine dienstleistende, ja auch im besten Sinne dienende Funktion ist sehr hilf- 
reich. Das bedeutet gleichzeitig einen gewissen Abstand $z u$ den inhaltichen Aspekten - sowohl eine fachwissenschaftliche Motivation ist hinderlich (sie gebührt allein den Nur-Forschenden!) als auch eine allzu starke Affinität zu den DH-Herausforderungen (dafür gibt es die spezialisierten Entwicklerinnen und Entwickler). Auf diese Weise wahrt eine Digitale Redaktion die Äquidistanz zur Fachwissenschaft und zur DH und kann ungeachtet aller Serviceprinzipien sehr stark auf die Projektführung einwirken - wobei hier eine moderierende, ausgleichende Art, gepaart mit viel Geduld von großem Nutzen ist.

Hört sich dies alles zu idealtypisch, ja vielleicht sogar übermenschlich an? Niemand kann und muss dies alles gleichmäßig stark beherrschen. Denn die Digitale Redaktion funktioniert vor allem als Team, in dem die einzelnen Mitglieder ihre unterschiedlichen Kompetenzen so einbringen, dass die verschiedenen Anforderungen abgedeckt werden. Die Digitale Transformation bleibt ohnehin eine Herausforderung, die verschiedene Akteursgruppen fordert - die Digitale Redaktion kann hierbei eine zentrale Rolle spielen: Sie berät die Projektbeteiligten, sie kann verschiedene Schritte im Projekt anleiten und begleiten, bei Interessenkonflikten zwischen den verschiedenen Stakeholdern kann sie vermitteln und moderieren, ja im Fall der Fälle ist sie dann auch der Sündenbock, der die Schuld für Probleme in einem Projekt übernimmt - solange es dem Fortschritt im Prozess der digitalen Transformation dient.

\section{Literaturverzeichnis}

Fabian Cremer, Mareike König, Katrin Neumann, Thorsten Wübbena: Ein stiftungsweiter Workshop zum Digitalen Publizieren, in: Digitale Redaktion, 06.05.2019. https://editorial. hypotheses.org/548.

Jennifer Edmonds: Collaboration and Infrastructure, in: Susan Schreibman, Ray Siemens, John Unsworth (Hrsg.): A New Companion to Digital Humanities, Chichester 2015, S. 54-67.

Ulrich Hagenmeyer: Integrative Unternehmensberatungsethik: Grundlagen einer professionellen Managementberatung jenseits reiner betriebswirtschaftlicher Logik, in: Zeitschrift für Wirtschafts- und Unternehmensethik 3 (2002) 3, S. 356-377. https://nbn-resolving. org/urn:nbn:de:0168-ssoar-347679.

Katrin Neumann, Fabian Cremer: Stolz und Vorurteil. Geisteswissenschaften und Open Access in einer Dekade perspectivia.net, in: Digitale Redaktion, 03.05.2018. https:// editorial.hypotheses.org/147.

Dies.: Zurück in die Zukunft II - keine erweiterten Publikationen in den Geisteswissenschaften?, in: Digitale Redaktion, 18.07.2018. https://editorial.hypotheses.org/231. 


\section{Einer für alle - Alle für einen. Kooperative und nachhaltige Softwareentwicklung in FuD-Projekten}

\section{Einleitung}

Spezialisierte Softwareanwendungen, die nur für einen konkreten Anwendungsfall entwickelt wurden, sind leider häufig in der Forschungslandschaft anzutreffen. Die zeit- und kostenaufwendigen Entwicklungen leisten gute Dienste für das eine Forschungsprojekt, sind aber für andere, manchmal sogar für ähnlich gelagerte Projekte nicht mehr oder kaum nachnutzbar, weil sie zu spezialisiert, zu wenig dokumentiert und die Entwickelnden nicht mehr verfügbar sind. Sie waren also nie als nachhaltiges Softwareprodukt gedacht. $\mathrm{Zu}$ dem fehlt es nach Projektabschluss meist sowohl an technischem als auch fachwissenschaftlichem Support. Die vorgenannten Punkte sind jedoch bei dem Einsatz von Forschungssoftware zur Einhaltung der Regeln guter wissenschaftlicher Praxis und der FAIR-Prinzipien zu berücksichtigen. ${ }^{1}$ Diesem Desiderat kann nur durch ein strategisches und kooperatives Vorgehen bei der Entwicklung und dem Regelbetrieb von Forschungssoftware entgegengewirkt werden, um einen nachhaltigen Betrieb solcher Infrastrukturen zu gewährleisten. ${ }^{2}$ Hierbei ist es wichtig, dass bei der Implementierung von Forschungssoft-

1 Vgl. Matthias Katerbow, Georg Feulner: Handreichung zum Umgang mit Forschungssoftware, hrsg. von Arbeitsgruppe Forschungssoftware im Rahmen der Schwerpunktinitiative Digitale Information der Allianz der deutschen Wissenschaftsorganisationen Allianz-AG Forschungssoftware, [Online] 2018. https://doi.org/10.5281/zenodo.1172970, S. 5-6.

2 Schon 2011 postulierte die Kommission "Informationsinfrastruktur" Forderungen nach verstärkter Nachnutzung bestehender Forschungsumgebungen und deren koordinierter Weiterentwicklung sowie die Ablösung zeitlich befristeter Fördermodelle durch nachhaltige, auf Dauer angelegte. Vgl. Kommission Zukunft der Informationsinfrastruktur KII: Gesamtkonzept für die Informationsinfrastruktur in Deutschland. Empfehlungen der Kommission Zukunft der Informationsinfrastruktur im Auftrag der Gemeinsamen Wissenschaftskonferenz des Bundes und der Länder, [Online] 2011. https://www.hof.uni-halle.de/web/dateien/KII_Gesamtkonzept_ 2011.pdf, S. 39-40 (letzter Zugriff: 09.08.2019). Die Situation hat sich bis heute eigentlich nicht viel verändert. Die Allianz-AG „Forschungssoftware“ formulierte 2018 Handlungs-empfehl- 
ware ${ }^{3}$ ein konzeptioneller Ansatz gewählt wird, der über die konkreten Anforderungen eines Projektes hinausgeht, um späterhin ähnlich gelagerte Anwendungsfälle mit der Software umsetzen zu können. Nur so ist die Nachnutzung durch andere Forschende überhaupt aussichtsreich. Dafür muss das Entwicklungsteam im engen Austausch mit der potentiellen Anwendungscommunity während des gesamten Entwicklungszyklus stehen, damit von ihnen einerseits die Gemeinsamkeiten scheinbar unterschiedlicher Anforderungen identifiziert werden, wodurch das Entwicklungsteam die Erkenntnis gewinnt, welche unterschiedlichen Anforderungen mithilfe einer neuen Funktion gelöst werden können. Andererseits schärfen sie auf diese Weise ihren Blick dafür, worin die kleinen Unterschiede beim Anwenden einer Funktionalität im konkreten Forschungskontext bestehen und können die Software entsprechend darauf ausrichten, indem sie diese bspw. für solche Aspekte konfigurierbar machen.

Die Handreichung der Allianz-AG „Forschungssoftware“ stellt wertvolle Informationen zum Betrieb von Forschungssoftware im Allgemeinen bereit, benennt die Herausforderung und zeigt Lösungsansätze auf. Sie konzentriert sich dabei auf die optimalen Rahmenbedingungen für die Bereitstellung von Forschungssoftware und -infrastrukturen. ${ }^{4}$ Doch wie wird ein Softwarekonzept entwickelt, das den Anforderungen einer größeren Forschungscommunity gerecht werden soll? Eine Antwort darauf sind die Philosophie, das Entwicklungskonzept, der Implementierungsprozess und die Kooperationsstrukturen der virtuellen Forschungsumgebung FuD. ${ }^{5}$ Dieser Beitrag wird erläutern, wie die koordinierte, projekt- und disziplinübergreifende Softwareentwicklung von FuD funktioniert, die sich in ihrem nun 15-jährigen Bestehen mittlerweile in über 40 laufenden und bereits abgeschlossenen Projekten bewährt hat. ${ }^{6}$ Ein Erfolgsfaktor, den dieser Beitrag erläutern wird, ist die Devise - angelehnt an das Motto der Musketiere - dass EINE Entwicklung FÜR ALLE konzipiert UND ALLE vorhergehenden und noch entstehenden Entwicklungen FÜR EIN Projekt (nach)genutzt werden können. Es wird in diesem Beitrag beschrieben,

ungen, die dazu dienen sollen, diesen Forderungen nachkommen zu können. Vgl. Katerbow, Feulner: Handreichung zum Umgang mit Forschungssoftware, S. 15.

3 Die Handreichung der Allianz-AG "Forschungssoftware" unterteilt in die drei Softwarekategorien: eigenentwickelte Forschungssoftware, Softwareanwendungen für die Forschung und Infrastruktursoftware bzw. -dienste. Vgl. Katerbow, Feulner: Handreichung zum Umgang mit Forschungssoftware, S. 6.

4 Vgl. Katerbow, Feulner: Handreichung zum Umgang mit Forschungssoftware.

5 www.fud.uni-trier.de. Vgl. Gisela Minn u. a.: FuD2015. Eine virtuelle Forschungsumgebung für die Geistes- und Sozialwissenschaften auf dem Weg in den Regelbetrieb, Trier 2016 (= eSciences Working Papers 01). http://nbn-resolving.de/urn:nbn:de:hbz:385-10103 (letzter Zugriff: 14.08.2019).

6 Vgl. Projektreferenzen auf der FuD-Webseite. https://fud.uni-trier.de/community/referenzen/ (letzter Zugriff: 14.08.2019). 
wie bei der Entwicklung einer neuen Funktionalität die Anforderungen aus den unterschiedlichen Forschungsprojekten berücksichtigt und in einem Softwarekonzept zusammengeführt werden, sodass EINE Entwicklung nicht nur von mehreren Forschenden angewendet, sondern auch für nachfolgende Forschungsvorhaben nachnutzbar wird. Auf diese Weise ist eine ressourcenschonende, nachhaltige und effiziente Entwicklung einer Forschungssoftware möglich.

\section{FuD - eine Forschungssoftware aus der Forschung für die Forschung}

$\mathrm{FuD}^{7}$ ist eine virtuelle Forschungsumgebung ${ }^{8}$ für die methodisch qualitativ forschenden Geistes- und Sozialwissenschaften, die Forschende in allen Phasen des Forschungsprozesses von der Datenaufnahme und -erschließung, über deren Analyse und Auswertung, bis hin zur Publikation und letztlich Archivierung und ggf. Bereitstellung der Forschungsdaten unterstützt. Dabei ist es für die zeit- und ortsunabhängige Zusammenarbeit konzipiert, um gleichzeitig und kollaborativ an gemeinsamen Datenbeständen und mit denselben Analysewerkzeugen/-methoden zu arbeiten.

Als 2004 der Grundstein für FuD im Rahmen des Sonderforschungsbereiches „Fremdheit und Armut" (SFB 600) gelegt wurde, war von Anfang an klar, dass diese Forschungsplattform Ansprüchen unterschiedlicher geistesund sozialwissenschaftlicher Disziplinen genügen muss. Denn von Hause aus ist ein Sonderforschungsbereich interdisziplinär aufgestellt und auf Kooperation der einzelnen Teilprojekte untereinander ausgelegt, um die Forschungsagenda, der er sich verpflichtet hat, umsetzen zu können. Aus den Erfahrungen beim Aufbau des „Informationsnetzwerk zur Geschichte des Rhein-MaasRaumes <RM.net> " 10 des vorangegangenen Sonderforschungsbereiches 235 „Zwischen Maas und Rhein: Beziehungen, Begegnungen und Konflikte in einem europäischen Kernraum von der Spätantike bis zum 19. Jahrhundert“"11 stand für das FuD-Entwicklungsteam fest, dass die Entwicklung der virtuellen Forschungsumgebung als Kooperationsprojekt zwischen dem SFB 600 und

7 FuD hat sich mittlerweile als eigenständiges Akronym etabliert, sodass die Auflösung „Forschungsnetzwerk und Datenbanksystem“ nicht mehr in Gebrauch ist.

8 Vgl. Arbeitsgruppe Virtuelle Forschungsumgebungen in der Allianz der deutschen Wissenschaftsorganisationen Allianz-AG VFU: Definition Virtuelle Forschungsumgebung, [Online] 2011. https://doi.org/10.2312/ALLIANZOA.028 (letzter Zugriff: 09.08.2019).

9 https:/gepris.dfg.de/gepris/projekt/5485009 (letzter Zugriff: 09.08.2019).

10 http://www.rmnet.uni-trier.de (letzter Zugriff: 09.08.2019).

11 https:/gepris.dfg.de/gepris/projekt/5474491 (letzter Zugriff: 09.08.2019). 
dem Trier Center for Digital Humanities 12 erfolgen muss. Es hatte sich im vorangegangenen Projekt bereits herausgestellt, dass ein Team, zusammengesetzt aus Fachwissenschaftlerinnen und -wissenschaftlern sowie Informatikerinnen und Informatiker, die kooperativ an Konzepten und Entwicklungen digitaler Arbeitskomponenten für fachspezifische Forschungskontexte zusammenarbeiten, notwendig ist, um nachhaltige Softwareentwicklung zu gewährleisten. Denn nur durch die enge Zusammenarbeit dieser zwei häufig als gegensätzlich empfundenen Disziplinen ist es möglich, eine bedarfsgerechte Software zu implementieren, die den disziplinspezifischen Anforderungen entspricht und somit von den Forschenden eingesetzt werden kann. Durch die Verankerung fachwissenschaftlicher Expertise im Entwicklungsteam wird eine ideale Schnittstelle zur Anwendungscommunity geschaffen, die den zu leistenden Übersetzungsprozess von den Forschenden $\mathrm{zu}$ den Entwickelnden und umgekehrt erheblich erleichtert. Dieser Ansatz und die ersten Systemkomponenten zur Datenerfassung und -analyse motivierten schon früh weitere Projekte außerhalb des SFB 600 und der Universität Trier, das System zu nutzen und es für die eigene Forschungsarbeit einzusetzen. Hieraus entstand nicht nur der Wunsch, sondern auch die Notwendigkeit, FuD über die Laufzeit des SFB 600 hinaus weiter zu betreiben und zu entwickeln. Ab 2013 wurde dann in dem zweijährigen DFG-Projekt „FuD2015 - eine virtuelle Forschungsumgebung für die Geschichtswissenschaften und ein Geschäftsmodell für deren Überführung in den Regelbetrieb"13 ein nachhaltiges Betriebsmodell für FuD entwickelt, das den Regelbetrieb mit der koordinierten Softwareentwicklung sowie die Beratungsservices langfristig gewährleistet. Mit Abschluss des DFGProjektes befindet sich die virtuelle Forschungsumgebung FuD seit Juli 2015 im Regelbetrieb am Servicezentrum eSciences ${ }^{14}$ der Universität Trier. Hier erfolgt das Releasemanagement der FuD-Basisversion und werden alle Services, ${ }^{15}$ die für die Einrichtung und den Betrieb einer FuD-Customerversion gebraucht werden (könnten), vom FuD-Basisteam sowohl für universitätsinterne als auch externe Projekte und Institutionen angeboten. ${ }^{16}$

Handlungsleitend für den Betrieb der Basisversion der virtuellen Forschungsumgebung und insbesondere für die Implementierung neuer Funktio-

12 Damals unter dem Namen Kompetenzzentrum für elektronische Erschließungs- und Publikationsverfahren in den Geisteswissenschaften bekannt. https://kompetenzzentrum.uni-trier.de/de/ (letzter Zugriff: 09.08.2019).

13 https://gepris.dfg.de/gepris/projekt/224201233 (letzter Zugriff: 09.08.2019).

14 www.esciences.uni-trier.de (letzter Zugriff: 09.08.2019).

15 Vgl. FuD-Leistungsbeschreibung. https://fud.uni-trier.de/download/fud-leistungsbeschreibung/ (letzter Zugriff: 09.08.2019).

16 Zum FuD-Betriebsmodell vgl. Gisela Minn u. a.: FuD2015 - Eine virtuelle Forschungsumgebung für die Geistes- und Sozialwissenschaften auf dem Weg in den Regelbetrieb. 
nen ist die FuD-Philosophie. Sie besagt, dass Neuentwicklungen 1. nur im konkreten Forschungs- und Anwendungskontext erfolgen, weil nur so die Anwendbarkeit der Funktion sichergestellt werden kann und eine valide Entscheidungsgrundlage existiert. Ganz pragmatisch gesehen ist so auch immer eine Gruppe von Beta-Testenden sichergestellt. 2. ist es bei der Konzepterstellung essenziell, sich stets am Forschungsprozess und an den gewohnten Arbeitsformen zu orientieren, um die Akzeptanz in der Community sicherzustellen. 3. werden bei der Softwarekonzeption stets die Anforderungen verschiedener Fachdisziplinen und/oder Forschungsprojekte in den Blick genommen und entsprechend berücksichtigt. 4. ist und bleibt die bewährte Zusammenarbeit von fachwissenschaftlichen Koordinatorinnen und Koordinatoren und Softwareentwickelnden Bestandteil der FuD-Philosophie. Nur durch sie ist 5. der integrative Ansatz der Projektbegleitung von der Konzeptionsphase bis zur Archivierung möglich, um alle notwendigen Arbeitsschritte möglichst effizient durchlaufen zu können. 6. soll die FuD-Software stets im Sinne der Nachnutzbarkeit weiterentwickelt werden. Denn nur auf einer aktiven Nutzung können Nachhaltigkeitskonzepte und Betriebsmodelle aufsetzen.

Daraus ergibt sich, dass neue Funktionalitäten stets in Zusammenarbeit mit den Forschenden und ihren Forschungsfragen implementiert werden. Dabei ist es die Aufgabe des FuD-Basisteams, dafür Sorge zu tragen, dass die neue Funktion nicht nur für das eine Forschungsprojekt anwendbar ist, das die Entwicklung anstößt und finanziert, sondern dass sie z. B. durch Konfigurationsoptionen für andere Anwendungsfälle nachnutzbar wird. So können ggf. Bedarfe, die aus unterschiedlichsten Projekten artikuliert wurden, über EINE Entwicklung abgedeckt werden. Diese „projektspezifischen“ Entwicklungen werden dann entsprechend der FuD-Philosophie allen anderen FuD-Nutzenden im Rahmen des Upgrades der Basisversion zur Verfügung gestellt, sodass alle von allen profitieren können. Das ist hinsichtlich der begrenzten Verfügbarkeit von Ressourcen nicht nur sinnvoll, sondern auch notwendig. Zudem können auf diese Weise auch Ressourcen aus verschiedenen Projekten kumuliert werden, um größere Entwicklungsarbeiten zu ermöglichen.

Nach welchen Prinzipien die Implementierung neuer Funktionalitäten in FuD erfolgt, wird in den nachfolgenden Abschnitten erläutert.

\section{FuD - Eine evolutionäre und adaptive Softwareentwicklung}

Softwareentwicklung an sich ist ein hochdynamisches Feld und erfordert regelmäßige technische Anpassungen an die sich stets weiterentwickelnden Hardware- und Betriebssysteme, um lauffähig zu bleiben. Für Forschungssoft- 
ware kommt erschwerend hinzu, dass Forschung per se dynamisch und innovativ ist. Somit muss Forschungssoftware bzw. deren Regelbetrieb den wechselnden Anforderungen gewachsen sein. Daher lag und liegt es in der Natur der Sache, dass die Genese von $\mathrm{FuD}$ als evolutionäre Softwareentwicklung beschrieben werden kann und dieser Software-Life-Cycle auch weiterhin umgesetzt werden muss. Denn durch immer wieder neue Anwendungsprojekte befindet sich das System in einem kontinuierlichen Entwicklungsprozess, der durchaus als evolutionär bezeichnet werden kann. Schließlich werden Funktionen entwickelt, die sich aus der Notwendigkeit neuer Anforderungen ergeben.

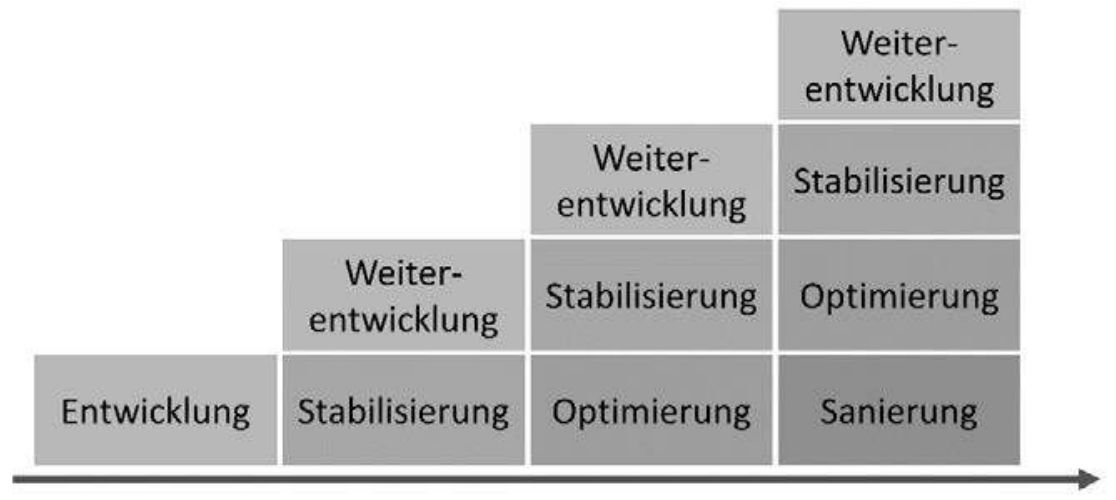

Abbildung 1: Wachsende Aufgaben bei der evolutionären Softwareentwicklung. Abbildung in starker Anlehnung an die Darstellung von Sneed, Seidl: Softwareelvolution, Abbildung 1 im Abschnitt 1.1.2.

Diese sollten sich im besten Fall nicht nur für das eine Projekt bewähren, sondern werden durch die Anforderungen der Nachnutzenden evaluiert und bei Bedarf weiterentwickelt. Manch eine frühe Komponente von FuD ist mittlerweile auch schon wieder ausgestorben und wurde durch eine andere Funktion ersetzt. Auch wenn es keine bewusste Entscheidung unsererseits war, diese Verfahren zu wählen, so bestätigt die Fachliteratur zur Softwareentwicklung, ${ }^{17}$ dass das FuD-Entwicklungsteam intuitiv, aber auch durch die Rahmenbedingungen des SFB 600, die richtige Vorgehensweise zur Entwicklung eines komplexen Softwaresystems gewählt hat. Dabei wurde in den ersten Jahren ein Kernsystem für die Inventarisierung und Analyse der Forschungsdaten entwickelt und in den Teilprojekten des SFB 600 zum Einsatz gebracht. In den nachfolgenden Entwicklungsphasen und heute in den Releasezyklen werden weitere Anforderungen der Nutzenden integriert sowie durch Nachbesserung das

17 Vgl. James A. Highsmith: Adaptive Software Development: A Collaborative Approach to Managing Complex Systems, New York 2013, S. 38-40. 
System konsolidiert und stabilisiert. Aufgrund der nun schon 15-jährigen Laufzeit fallen mittlerweile auch Aufgaben zur Sanierung des Systems an (siehe Abbildung 1). ${ }^{18}$

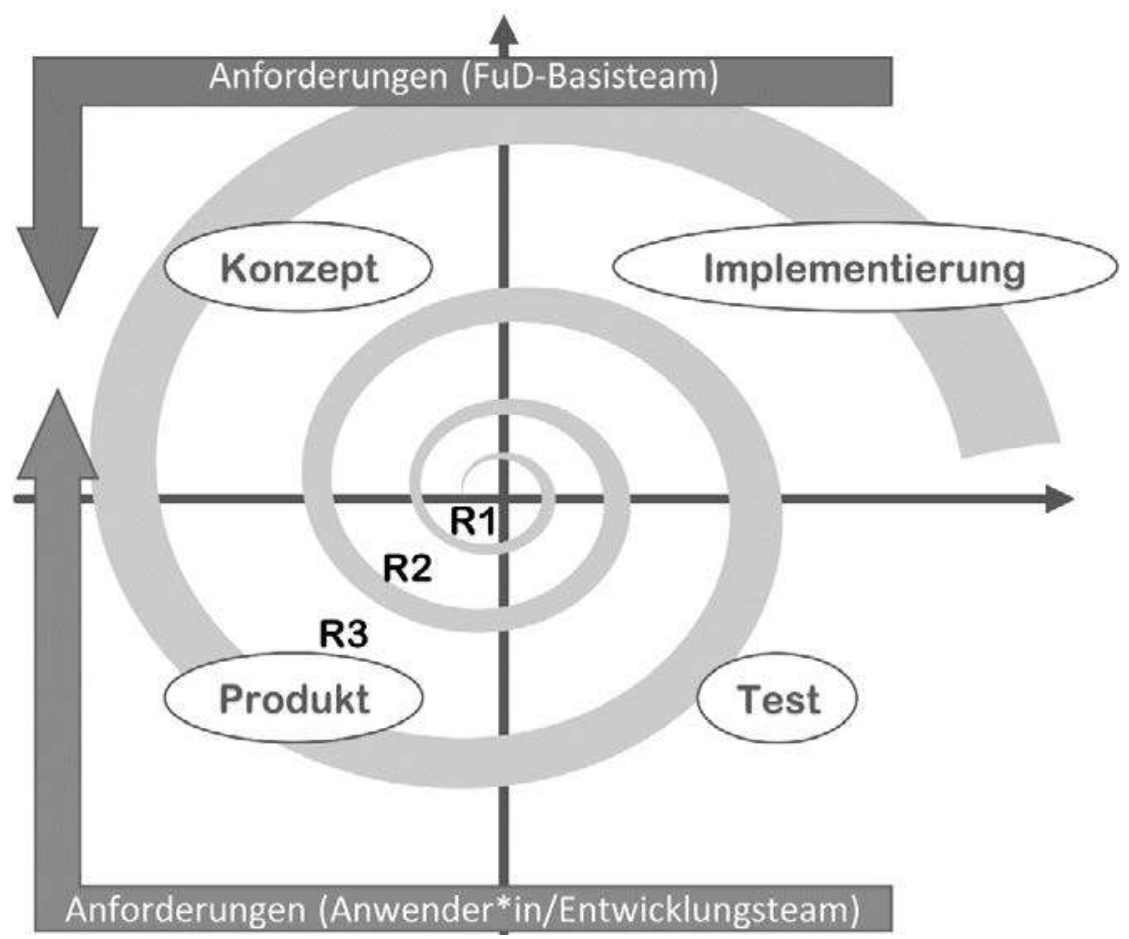

Abbildung 2: Spiralmodell nach Boehm (1988), S. 64, Abbildung 2. Adaptiert an die FuD-Softwareentwicklung.

Dadurch, dass stets neue Nutzungsanforderungen in das System integriert werden, ist die Entwicklung nie abgeschlossen. Somit durchläuft das System einen steten Zyklus aus Konzepterstellung, Quellcodeentwicklung, Test und Debugging mit anschließendem Produktivgang, wie in Abbildung 2 dargestellt. FuD wächst also mit jedem Releasezyklus. ${ }^{19}$ Dies entspricht dem Spiralmodell von Barry W. Boehm. ${ }^{20}$ Dabei wird bei der Entwicklung von FuD vor allem in der Konzeptphase einer neuen Funktion viel Wert daraufgelegt, die Anforderungen aus den unterschiedlichen Projekten mit den Prinzipien, die sich aus

18 Vgl. Harry M. Sneed, Richard Seidl: Softwareevolution: Erhaltung und Fortschreibung bestehender Softwaresysteme, Heidelberg 2013, Abschnitt 1.1.2.

19 R 1-R 3 in der Abbildung 2.

20 Vgl. Barry W. Boehm: A Spiral Model of Software Development and Enhancement, in: IEEE Computer 21.5 (1988), S. 61-72. 
der FuD-Philosophie heraus ergeben, in Einklang zu bringen. Dabei sollen die beiden äußeren Pfeile in der Abbildung 2 veranschaulichen, dass die Anforderungen des FuD-Basisteams hauptsächlich aus der Erfahrung der vorherigen Implementierungen hervorgehen und die des einzelnen Entwicklungsteams bzw. der nachfolgenden Nutzenden aus der Phase der produktiven Nutzung bzw. des Testens.

\section{Design Thinking im FuD-Implementierungsprozess}

Kooperativ meint für die Entwicklung von FuD nicht nur, dass viele Programmierende gemeinsam eine Software implementieren, sondern kooperativ im FuD-Sinne meint auch und gerade, dass gemeinsam mit den Anwendenden, den Informatikerinnen und Informatikern und den Koordinatorinnen und Koordinatoren Ideen und Lösungen für die Umsetzung der einzelnen Forschungsfragen und -aufgaben in ein digitales Forschungsdesign entwickelt werden. Hierfür bestand und besteht das FuD-Team von Anfang an aus Informatikerinnen und Informatikern und Geisteswissenschaftlerinnen und Geisteswissenschaftlern, weil sich das Vorhandensein von technischer und fachlicher Expertise bei der Begleitung der Anwendungsprojekte als Erfolgsfaktor herausgestellt hat. Dieses interdisziplinäre Team ist ein Aspekt, den das FuD-Beratungs- und Serviceangebot mit der Design-Thinking-Methode gemein hat. Der Begriff Design Thinking wird dem Mitbegründer der Designund Innovationsagentur IDEO und Professor der Stanford University David Kelly zugeschrieben, der beim auf Innovation ausgerichteten Designprozess immer das Wort thinking mit eingebracht hatte. ${ }^{21}$ Design Thinking wird als nutzerorientierter Ansatz für komplexe Problemlösung verstanden, bei dem ein iteratives Phasenmodell sich nach den Wünschen und Bedürfnissen der Anwendenden richtet. Anhand ihrer Anforderungen werden Prototypen entwickelt und getestet. Die Testergebnisse können wieder zu Optimierungen und Anpassungen der Konzepte und Weiterentwicklungen führen. ${ }^{22}$ Es soll im Folgenden gezeigt werden, wie sich der FuD-Beratungs- und Entwicklungsprozess in den sechs Design-Thinking-Phasen „Verstehen, Beobachten, Anwendersicht definieren, Ideenfindung, Prototypentwicklung und Testen“ wi-

21 Vgl. Tim Brown, Jocelyn Wyatt: Design Thinking for Social Innovation, in: Stanford Social Innovation Review 8.1 (2010), S. 30-35, hier S. 33.

22 Vgl. Brown, Wyatt: Design Thinking for Social Innovation; Hasso-Plattner-Institut: Was ist Design Thinking? HPI Academy. Education for Professionals. https://hpi-academy.de/designthinking/was-ist-design-thinking.html (letzter Zugriff: 12.08.2019); Sven Poguntke: Definition: Design Thinking, in: Gabler Wirtschaftslexikon [Online] 2018. https://wirtschaftslexikon .gabler.de/definition/design-thinking-54120/version-277174 (letzter Zugriff: 12.08.2019). 
derspiegelt, bevor eine Implementierung neuer Entwicklungen in das FuDBasissystem erfolgt. ${ }^{23}$

Verstehen: Am Anfang einer FuD-Kooperation steht das Gespräch mit den Forschenden der Kooperationsprojekte. Hierbei wird, ganz im Sinne der ersten Phase des Design-Thinking-Prozesses, erst einmal von unserem Team nach den Forschungsfragen und dem Erwartungshorizont des Projektes gefragt. Wichtig hierbei ist das Verständnis für den Forschungsansatz, die Methodik und deren Implikationen auf die Ergebnisse. Wir versuchen, Vertrauen für das Projekt aufzubauen, dessen Herausforderungen und Nöte zu verstehen, um diese dann in Lösungsvorschläge unsererseits umzusetzen. Im Prinzip gilt es herauszufinden, was die Nutzenden wollen und wie ihre Ziele aussehen. Die Artikulierung, welche Anforderungen die Forschenden an die digitale Arbeitsumgebung oder ihr digitales Forschungsdesign im Allgemeinen haben, ist dabei für die Forschenden selbst manchmal sehr schwierig. Von daher werden in Beratungsgesprächen diese herausgearbeitet, indem gemeinsam von den Ergebnissen und der späteren Zielgruppe her gedacht wird, um dann hieraus in den nächsten Stufen des Prozesses Schlussfolgerungen und Ideen zu sammeln, wie diese Ziele zu erreichen sind. ${ }^{24}$ Das Softwarekonzept wird also im Einklang mit dem ersten Punkt unserer FuD-Philosophie am konkreten Anwendungsfall weiterentwickelt.

Beobachten: In einem nächsten Schritt wird nach dem Arbeitsprozess gefragt, wie und mit welchen Methodiken das Projekt seine Ziele erreichen will. Hier beobachten wir, wie die Abläufe im Projekt organisiert sind, um diese späterhin als Anhaltspunkte für die Abbildung des Workflows in der digitalen Arbeitsumgebung zu nutzen. Gemeinsam strukturieren wir so den digitalen Arbeitsprozess und bauen ein System auf, das so nah wie möglich am bisherigen Arbeitsprozess der Forschenden liegt. Auch hier findet sich unsere Prämisse wieder, die Konzepterstellung und Workflowimplementierung am Forschungsprozess und an den gewohnten Arbeitsweisen der Forschenden zu orientieren.

Anwendersicht definieren: Bei der Konfiguration der FuD-Arbeitsumgebung wird viel Wert auf die Anwendenden und deren Sichtweise gelegt. Die Konfigurationstools in FuD sind so angelegt, dass sie flexibel auf unter-

23 Vgl. Beke Redlich, Christopher Rechtien, Nina Schaub: Auf das Mindset kommt es an! Design Thinking für industrienahe Dienstleistungen analog oder digital, in: HMD Praxis der Wirtschaftsinformatik 56.1 (2019). https://doi.org/10.1365/s40702-018-00482-6, S. 121-134, hier S. 125.

24 Zur Entwicklung eines digitalen Forschungskonzeptes für geisteswissenschaftliche Forschungsprojekte vgl. Marina Lemaire: Vereinbarkeit von Forschungsprozess und Datenmanagement. Forschungsdatenmanagement nüchtern betrachtet, in: o-bib. Das offene Bibliotheksjournal 5.4 (2018), S. 237-247. https://doi.org/10.5282/o-bib/2018H4S237-247. 
schiedliche Anwendungsszenarien reagieren können, ohne direkt Neuentwicklungen zu bedingen. So können z. B. Dokumentmasken für die Datenerfassung auf die projektspezifischen Anforderungen und Bedürfnisse angepasst werden, ohne die Grundstruktur und -funktionalitäten von FuD zu beeinträchtigen. Es geht uns in dieser Phase auch darum, durch eine konsequente Bedarfsanalyse der Nutzerperspektive eine Vertrauensbasis aufzubauen, um gemeinsam lösungs- und ergebnisorientiert ein Anforderungsprofil für das Forschungsprojekt zu erstellen. Wenn Neuentwicklungen erforderlich sind, wird stets überlegt, wie eine allgemeine Anwendersicht über den projektspezifischen Bedarf hinaus, z. B. für eine Fachcommunity, aussehen könnte. Des Weiteren wird geprüft, ob eine Generalisierung des Konzepts im Rahmen des Entwicklungsprojektes machbar ist und wie dafür die zunächst projektspezifischen Konzepte angepasst bzw. erweitert werden müssen. In den meisten Fällen gelingt dies dadurch, dass die neue Funktion parametrisiert und konfigurierbar implementiert wird. Sollte diese allgemeine Umsetzung in einem ersten Schritt zu aufwendig sein, werden bei der Implementierung der projektspezifischen Lösung Vorkehrungen getroffen, sodass bei einer späteren Umsetzung des allgemeinen Konzepts auf der projektspezifischen Entwicklung aufgebaut werden kann. Diese Phase findet sich ebenso in unserer Grundidee wieder, da wir von Anfang an bei der Softwarekonzeption stets die Anforderungen und Bedürfnisse unterschiedlicher geisteswissenschaftlicher Fachcommunities berücksichtigen.

Ideenfindung: Gemeinsam werden Konzepte entwickelt, welche Funktionalitäten wie genutzt werden, welche neuen Funktionalitäten implementiert werden sollen und wie der Arbeits- und Zeitplan aussieht. Hierbei erweist es sich für das FuD-Team als besonders hilfreich, mit den Projektmitarbeitenden einerseits den konkreten Anwendungsfall zu besprechen, andererseits bei den wöchentlichen FuD-Entwicklertreffen das bedarfsspezifische Konzept zu verallgemeinern und auf andere laufende, vergangene und potenzielle Nutzungsszenarien zu übertragen. Dies alles mündet dann in ein Gesamtkonzept, das mit den Projektmitarbeitenden wiederum abgesprochen und ggf. noch angepasst wird. Sowohl das interdisziplinäre Team von FuD als auch die Kooperationen mit Projekten aus den unterschiedlichsten Disziplinen erweisen sich hier als besonders gewinnbringend.

Prototyp entwickeln: Anhand des erstellten Konzeptes wird ein Prototyp der Funktion entwickelt. Durch den modularen Aufbau von FuD kann das neue Modul in das Gesamtsystem eingefügt werden, ohne die anderen Funktionalitäten von $\mathrm{FuD}$ zu beeinträchtigen. Hier hat es sich als hilfreich erwiesen, dass die Kernelemente von FuD von Anfang an auf Flexibilität, Nachhaltigkeit und Optimierung ausgelegt sind. Dieser Prototyp wird dann in eine Test- 
version von FuD eingespielt, um die neue Funktionalität im Gesamtsystem von FuD in der nächsten Phase zu testen.

Testen: Der Prototyp wird in einem ersten Schritt vom FuD-Team auf die Anforderungen des Projektes hin getestet, für das er entwickelt wurde. Da die Koordinatorinnen und Koordinatoren sich schon vorher mit dem Projekt intensiv ausgetauscht haben und mit deren Sichtweise vertraut sind (s. Phase Anwendersicht definieren), können die Tests in einem ersten Schritt FuDintern erfolgen. Es kann noch zu Anpassungen im Konzept, aber auch zu Nachfragen an das Projekt selbst kommen, die wiederum an den in den vorherigen Phasen gemachten Annahmen Veränderungen bedingen, die sich wiederum auf Konzept und Umsetzung auswirken könnten. Ebenfalls im Blick behält das FuD-Team die verallgemeinerte Anwendersicht, um auch auf die Anforderungen hin $\mathrm{zu}$ testen, die nicht direkt im Anwendungsprojekt gestellt wurden. Dieser Prozess wird in einem Prototyp für das Projekt abgeschlossen. Da Entwicklungen in FuD für einen konkreten Anwendungsfall programmiert werden, steht in einem zweiten Schritt mit den Projektmitarbeitenden schon eine Beta-Testgruppe bereit, die die Umsetzung direkt in ihrer Projektarbeit testen kann. Somit ist der konkrete Anwendungsfall als Testobjekt sichergestellt, sodass hier aus der Anwenderperspektive nutzungs- und zielorientiertes Feedback gegeben wird. Es kommt auch hier ggf. noch einmal zu Anpassungen, bevor die Funktionalität endgültig in die projektspezifische FuDUmgebung implementiert und für die Projektarbeit freigegeben wird.

Nach der Implementierung in der FuD-Instanz des Anwenderprojektes erfolgt zumeist mit der nächsten Releaseversion auch die Integration der neuen Funktionalität in das FuD-Basissystem und steht dann der FuD-Community zur Verfügung. So kommt die eine Entwicklung wieder allen FuDAnwendungsprojekten zu Gute und wird von ihnen eingesetzt und damit getestet. Der iterative Prozess ist mit der Implementierung also nicht abgeschlossen, da durch Rückmeldungen laufender Projekte oder auch durch die Anforderungen neuer Projekte Konzepte und Implementierungen immer wieder weiterentwickelt werden können. So arbeiten alle gemeinsam daran, das FuDBasissystem für jedes einzelne Projekt zu optimieren.

Als ein Beispiel einer Funktionalität, die sich über Jahre durch die Zusammenarbeit mit immer mehr Projekten und deren Anforderungen ergeben hat, sei hier nur kurz die Evolution der Sachanalyse in FuD skizziert. Eine Grundfunktionalität von FuD von Anfang an ist, Textpassagen mit einem Lemma aus einem Analyseindex zu annotieren. Dies war schon 2005 in das System integriert worden, wobei es noch sehr statisch und unflexibel war, weil die konkreten Anforderungen des SFB 600 viel zu spezifisch umgesetzt worden waren. Hier wurde noch mit größtenteils inhaltlich vordefinierten Analyseindizes 
gearbeitet. Zwar war es bereits möglich, einzelne Lemmata mit weiteren Informationen $\mathrm{zu}$ versehen, doch es gab unabhängig vom Analyseindex nur vier Zusatzfelder (vgl. Abbildung 3, linkes Bild). Diese Felder waren zudem nur einfache Textfelder, in die nur ein Text eines bestimmten Umfangs eingegeben werden konnte. Schnell stellten die Anwendenden fest, dass auch hier das Hinterlegen von Listen zur einheitlichen Erfassung von Zusatzinformationen wichtig im kollaborativen Arbeitsprozess ist. Des Weiteren reichten die vier Felder nicht mehr aus, um weitere Informationen zum Lemma selbst zu sammeln. Auch bedurften neue Methoden, die eingesetzt wurden, z. B. die Argumentationsanalyse (vgl. Abbildung 3, rechtes Bild), ebenfalls einer Anpassung der Funktionalitäten.
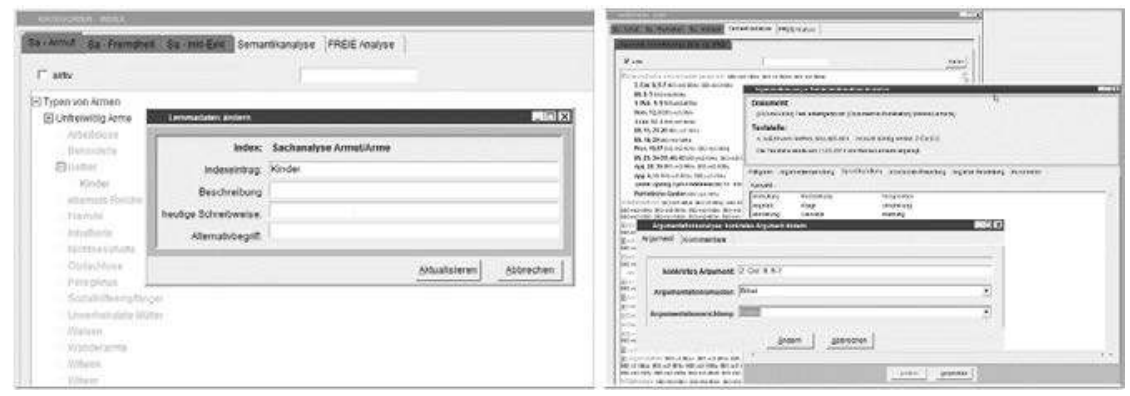

Abbildung 3: linkes Bild: Sachanalyse im SFB 600 (ca. 2005), rechtes Bild: Argumentationsanalyse (ca. 2007).

Weitere Anpassungen folgten über die Jahre, da immer wieder neue Bedürfnisse der Forschenden erfüllt werden mussten. So können seit 2014 auch Analyseindizes in Inventarisierungsmasken verwendet werden, um beispielsweise Personen eindeutig zu identifizieren, aber auch um verschiedene Informationsobjekte über einen Analyseindex miteinander in Beziehung zu setzen, indem beispielsweise alle Dokumententypen auf denselben Personenindex zugreifen. ${ }^{25}$ Seit dem Release 1.1 .0 (2016) können in Anlehnung an die freie Konfigurierbarkeit der Erfassungsmasken von Dokumenttypen auch zusätzliche Felder sowohl in den Eigenschaften der Lemmata als auch Textpassagen flexibel auf die jeweiligen projektspezifischen Anforderungen angepasst werden. Des Weiteren können diesen einzelnen Feldern ihrerseits Funktionen zugeordnet werden, sodass z. B. Lemmata auf andere Lemmata verweisen oder

25 Vgl. Release-History FuD: Version 0.4.8. https:/fud.uni-trier.de/releases/release-version-0-4-8/ (letzter Zugriff: 12.08.2019). 
mit FuD-Dokumenten oder externen Quellen (GND, Webseiten etc.) verlinkt werden können (vgl. Abbildung 4). ${ }^{26}$

Dieser Evolutionsprozess ist noch lange nicht abgeschlossen, denn die geisteswissenschaftlichen Disziplinen haben erst angefangen, ihre Arbeitsweisen auf die digitale Welt zu übertragen. Daher werden ganz nach dem Prinzip der evolutionären Softwareentwicklung und des Design Thinking durch Nutzung und weitere Projekte neue Funktionalitäten notwendig und sind nach dem bewährten Prinzip gemeinsam mit den Anwendenden zu entwickeln. So ist beispielsweise in der letzten Releaseversion 2.2 ein neues Feld zur Verknüpfung von Lemmata und Bibliographieeinträgen aus einer Zotero-Datenbank hinzugekommen. Ebenso ist die Anzeige und Bearbeitung der zusätzlichen Lemmafelder nun auch in der Inventarisierung möglich.
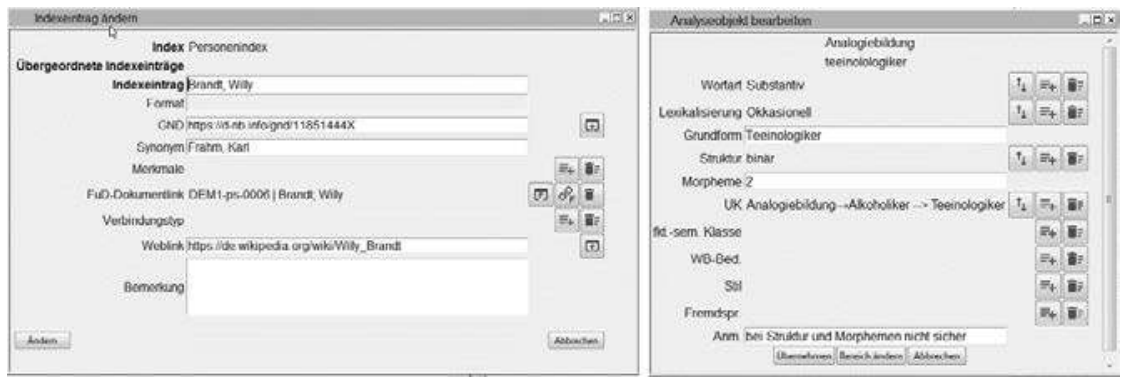

Abbildung 4: Beispiel von Index- und Textstellenkonfigurationen: Linkes Fenster: Personenindex der Demoversion, rechtes Fenster: Textstelleneigenschaften aus dem Projekt „Wortbildung in Mündlichkeit und Schriftlichkeit. Beziehungen zwischen Wort- und Textbildung im geschriebenen und gesprochenen Deutsch“ (Universität Trier, Germanistische Linguistik).

\section{FuD-Kooperationsstrukturen ${ }^{27}$}

Um das bisher dargelegte Modell umsetzen zu können, bedarf es einer adäquaten Kooperationsgovernance. Von daher wird zum Schluss vorgestellt, wer sich in welcher Rolle am FuD-Kooperationsmodell beteiligt und wie sich die Aufgaben hinsichtlich dieser einzelnen Akteursgruppen verteilen. Es lassen sich folgende Typen von Akteurinnen und Akteuren definieren, die aktiv an der FuD-Weiterentwicklung mitwirken:

26 Vgl. Release-History FuD: Version 1.1.0. https://fud.uni-trier.de/releases/release-version-1-1-0/ (letzter Zugriff: 12.08.2019).

$27 \mathrm{Zu}$ den Akteuren und ihren Zuständigkeiten, vgl. Minn u. a.: FuD2015 - Eine virtuelle Forschungsumgebung für die Geistes- und Sozialwissenschaften auf dem Weg in den Regelbetrieb, S. 8-9. 
Das FuD-Basisteam, beheimatet am Servicezentrum eSciences der Universität Trier, ist verantwortlich für die mit dem Regelbetrieb verbundenen zentralen Aufgaben, das Releasemanagement, die Dokumentation und die strategische Weiterentwicklung des Softwaresystems. Ferner betreut und koordiniert es die FuD-Koordinationsteams sowie die eigenen FuD-Projektteams mit ihren FuD-Customerversionen. Der Aufbau und die Pflege der FuD-Community ist ebenso ein Teil des Arbeitsspektrums. Es übernimmt Aufgaben in den Bereichen Management, Fachkoordination, Programmierung und Web-Design.

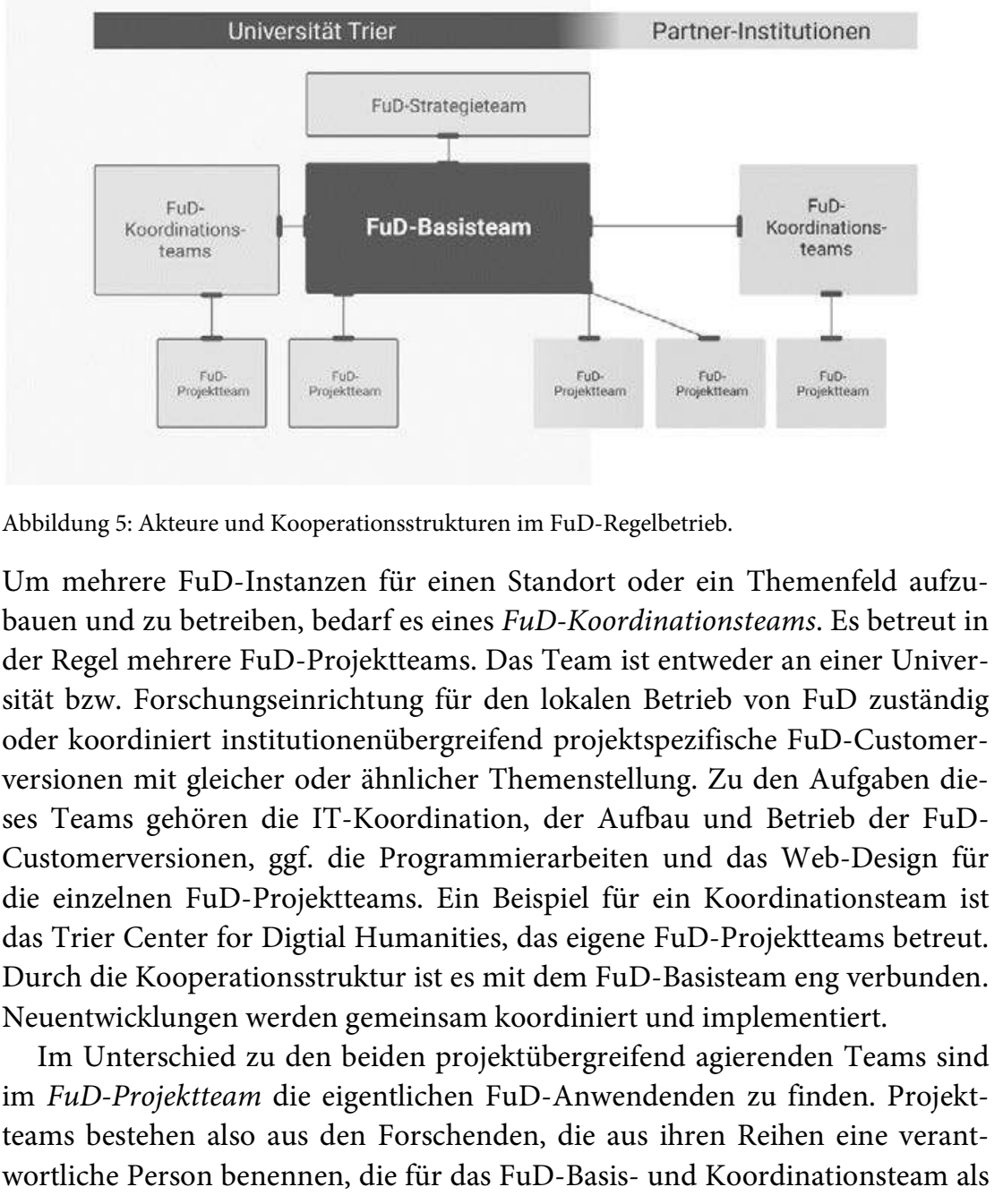


Ansprechpartner fungiert. Mit dieser werden die Konfigurationen und Entwicklungen abgesprochen und diese ist für den Informationsfluss in das Projektteam verantwortlich. Die Aufgaben des Projektteams liegen dahingehend vor allem im Management ihrer FuD-Anwendung und der Kommunikation im eigenen Forschungsteam. Aber auch hier können Programmentwicklungen oder Web-Design-Aufgaben von Teammitgliedern übernommen werden. Dies ist meist dann der Fall, wenn nicht der komplette Arbeitsprozess mit FuD durchgeführt wird, sondern z. B. die Webpublikation in einem anderen System erfolgt. Das Projektteam spricht sich hier entweder mit seinem Koordinationsteam oder mit dem FuD-Basisteam ab, um z. B. die Übergabe der Daten oder die Programmierung der Schnittstelle mit dem Softwarekonzept von FuD in Einklang zu bringen.

Losgelöst von den operativen FuD-Teams ist das FuD-Strategieteam zu sehen. Dieses übernimmt Aufgaben im Bereich der Planung und Umsetzung der strategischen Weiterentwicklung von FuD. Hier wird das Augenmerk darauf gerichtet, die interdisziplinäre Weiterentwicklung der FuD-Basisversion und deren Einbindung in übergeordnete Infrastrukturen langfristig sicherzustellen. Das FuD-Strategieteam besteht zurzeit aus dem Servicezentrum eSciences, dem Forschungszentrum Europa ${ }^{28}$ und dem Trier Center for Digital Humanities und ist an der Universität Trier angesiedelt.

\section{Schlussfolgerung}

Anhand der FuD-Philosophie, dem Entwicklungskonzept, dem Implementierungsprozess und den Kooperationsstrukturen wurde aufgezeigt, wie nachhaltige und kooperative Softwareentwicklung gelingen kann. Die konsequente Ausrichtung auf konkrete Anforderungen aus Forschungsprojekten, die direkte Einbindung der Forschenden sowie die Orientierung an den forschungsimmanenten Workflows erweisen sich als Erfolgsfaktoren. Diese Strategie, kombiniert mit den Konzepten der evolutionären und adaptiven Softwareentwicklung sowie des Design Thinking, ermöglicht die stetige Optimierung und die bedarfsgerechte Weiterentwicklung von FuD. Ein weiterer Grundpfeiler ist die von Anfang an auf Kooperation ausgelegte Entwicklungsstrategie von FuD. So entsteht ein offenes und erweiterbares Netzwerk von FuD-Anwendenden und -Expertinnen und Experten, das institutionenübergreifend organisiert ist und den Wissenstransfer innerhalb des Netzwerks gewährleistet. Durch die flexible Zusammensetzung der Teams entstehen Arbeitsgruppen aus der Fachwissenschaft, der Informatik und Informationsspezialistinnen und -spezialisten, die

28 https://fze.uni-trier.de (letzter Zugriff: 29.02.2020). 
die verschiedenen notwendigen Kompetenzen und Qualifikationen zusammenbringen, die für die Realisierung digitaler Arbeitsweisen notwendig sind. ${ }^{29}$ Diese Diversität hilft allen Beteiligten, über den Tellerrand ihrer eigenen Fachdisziplin und des eigenen Projektes hinauszublicken, um nicht nur die eigenen Kompetenzen zu erweitern, sondern insbesondere um nachhaltige Softwareentwicklungen $\mathrm{zu}$ ermöglichen, die von anderen Projekten nachgenutzt werden können. Indem in einem konkreten Anwendungsfall eine neue Funktion mit dem Ziel entwickelt wird, dass sie für alle nachnutzbar ist, können alle anderen von dieser einen Entwicklung profitieren. Nur auf diese Weise ist FuD so leistungsstark und vielseitig einsetzbar geworden, weil jedes neue Anwenderprojekt auf alle vorangegangenen Entwicklungen zurückgreifen durfte und konnte. Mit diesem EINER-FÜR-ALLE-UND-ALLE-FÜR-EINEN-PRINZIP kann nachhaltige Softwareentwicklung gelingen, was FuD mit seinen 15 Jahren Bestand und der weiterhin wachsenden Nachfrage eindrucksvoll beweist.

\section{Literaturverzeichnis}

Arbeitsgruppe Virtuelle Forschungsumgebungen in der Allianz der deutschen Wissenschaftsorganisationen Allianz-AG VFU: Definition Virtuelle Forschungsumgebung. [Online] 2011. DOI: https://doi.org/10.2312/ALLIANZOA.028.

Barry W. Boehm: A Spiral Model of Software Development and Enhancement, in: IEEE Computer 21.5 (1988), S. 61-72.

Tim Brown, Jocelyn Wyatt: Design Thinking for Social Innovation, in: Stanford Social Innovation Review 8.1 (2010), S. 30-35.

Hasso-Plattner-Institut: Was ist Design Thinking? HPI Academy. Education for Professionals. https://hpi-academy.de/design-thinking/was-ist-design-thinking.html.

James A. Highsmith: Adaptive Software Development: A Collaborative Approach to Managing Complex Systems, New York 2013.

Matthias Katerbow, Georg Feulner: Handreichung zum Umgang mit Forschungssoftware, hrsg. von Arbeitsgruppe Forschungssoftware im Rahmen der Schwerpunktinitiative Digitale Information der Allianz der deutschen Wissenschaftsorganisationen Allianz-AG Forschungssoftware, [Online] 2018. DOI: https://doi.org/10.5281/zenodo.1172970.

Kommission Zukunft der Informationsinfrastruktur KII: Gesamtkonzept für die Informationsinfrastruktur in Deutschland. Empfehlungen der Kommission Zukunft der Informationsinfrastruktur im Auftrag der Gemeinsamen Wissenschaftskonferenz des Bundes und der Länder. [Online] 2011. https://www.hof.uni-halle.de/web/dateien/KII_Gesamtkon zept_2011.pdf.

29 Die Diversität von Teams ist für Digitalisierungsprozesse und Innovation von entscheidender Bedeutung. Vgl. Isabell M. Welpe, Prisca Brosi, Tanja Schwarzmüller: Digital Work Design: Die Big Five für Arbeit, Führung und Organisation im digitalen Zeitalter, Frankfurt/New York 2018, S. 71-72. 
Marina Lemaire: Vereinbarkeit von Forschungsprozess und Datenmanagement. Forschungsdatenmanagement nüchtern betrachtet, in: o-bib. Das offene Bibliotheksjournal 5.4 (2018), S. 237-247. DOI: https://doi.org/10.5282/o-bib/2018H4S237-247.

Gisela Minn u. a.: FuD2015 - Eine virtuelle Forschungsumgebung für die Geistes- und Sozialwissenschaften auf dem Weg in den Regelbetrieb, Trier 2016 (= eSciences Working Papers 01). http://nbn-resolving.de/urn:nbn:de:hbz:385-10103.

Sven Poguntke: Definition: Design Thinking, in: Gabler Wirtschaftslexikon [Online] 2018. https://wirtschaftslexikon.gabler.de/definition/design-thinking-54120/version-277174.

Beke Redlich, Christopher Rechtien, Nina Schaub: Auf das Mindset kommt es an! Design Thinking für industrienahe Dienstleistungen analog oder digital, in: HMD Praxis der Wirtschaftsinformatik 56.1 (2019), S. 121-134. DOI: https://doi.org/10.1365/s40702-01800482-6.

Harry M. Sneed, Richard Seidl: Softwareevolution: Erhaltung und Fortschreibung bestehender Softwaresysteme, Heidelberg 2013.

Isabell M. Welpe, Prisca Brosi, Tanja Schwarzmüller: Digital Work Design: Die Big Five für Arbeit, Führung und Organisation im digitalen Zeitalter, Frankfurt/New York 2018. 
Open-Access-Publikation im Sinne der CC-Lizenz BY-SA 4.0 ๑ 2020 , Vandenhoeck \& Ruprecht GmbH \& Co. KG, Göttingen ISBN Print: 9783847111771 - ISBN E-Lib: 9783737011778 
Mark Hall

\section{Opportunities and Risks in Digital Humanities Research}

\section{Introduction}

The term Digital Humanities (DH) has established itself as one of the main umbrella terms under which humanities research that incorporates digital aspects is organised. The various different terms and computational areas that had developed in the individual humanities disciplines have slowly been coalescing under this new term, bringing with them a wide variety of methods and data. This has created the necessary critical mass and exchange of ideas that has led to a rapid development of a wide range of new methods and tools for investigating humanities research questions. Over time these have become easier to use and the $\mathrm{DH}$ field has expanded outward to include researchers who are no longer directly interested in developing methods and tools, but who use the methods and tools in the pursuit of their own research questions.

While there has been much discussion about where the boundaries of $\mathrm{DH}$ lie, ${ }^{1}$ in this article I will take a very broad definition, including any research that makes use of or plans to make use of digital tools or methods. The reason for this is that the use of any tool changes how we interact with the world, even if the tool is just a word-processor, but already much more so when it is a spreadsheet, and significantly more when algorithms are applied to data. Although it has been suggested that just working with digital materials is not sufficient to be counted into $\mathrm{DH},{ }^{2}$ I believe that the true value of $\mathrm{DH}$ can only be achieved if the term is used in an extended definition that goes beyond those who are interested in developing the methods and algorithms to encompass

1 Matthew G. Kirschenbaum: What is Digital Humanities and What's It Doing in English Departments, in: Matthew K. Gold (ed.): Debates in the Digital humanities, Minneapolis 2012, pp. 3-11; Bethany Nowviskie: Digital Humanities in the Anthropocene, in: Digital Scholarship in the Humanities, 30.1 (2015), pp. i4-i15; John Unsworth: What is Humanities Computing and What is Not?, in: Melissa Terras, Julianne Nyhann, Edward Vanhoutte (eds.): Defining Digital Humanities, London/New York 2016, pp. 51-63.

2 Kathleen Fitzpatrick: The Humanities, Done Digitally, in: Gold: Debates, pp. 12-15. 
data and tool users. For this wider group we need to make the case for why they should add digital aspects to their research, but more importantly they need to be aware of the major risks that adding computational methods to their repertoire of research methods present. An awareness of the pros and cons of the computational methodologies will enable them to correctly judge the impact of the digital tools they are employing on the outcomes that they observe and the conclusions they can draw.

At the same time, I will make some assumptions about the research context and particularly the kind of data used in the $\mathrm{DH}$ research. The assumption is that the data under investigation is of a historic nature, primarily text based, and from a time-period long enough ago, that a verification of any research results through other, independent sources is no longer possible. ${ }^{3}$ The focus on text is due to the prevalence of text as the primary data type in $\mathrm{DH}$ projects and also in the wider humanities. ${ }^{4}$ However, the main arguments about the advantages and risks of DH tools and algorithms apply to other data-types (images, sound, video, meta-data, etc. ) equally and some of the examples will be drawn from that wider set to illustrate that. Similarly, while the critique applies also to current non-historic data or data where verification through other sources is possible, the degree to which it is relevant varies, in particular as for newer data it is often easier to mitigate the potential risks. However, where verification or triangulation is possible, it also has to be applied, otherwise the issues raised here are just as valid.

The aim of this article is both to encourage researchers to consider making use of the digital methods and tools that are out there, while at the same time reminding everybody of the risks that these introduce into their research. As a result the remainder of the article is structured as follows: first I will discuss the main opportunities provided by the $\mathrm{DH}$ methods and tools (if you already use these, you might skip this), then I will spend significant time analysing the risks posed by poor methodology and use of the tools, and finally I will discuss the potential dangers for $\mathrm{DH}$ as a field if the risks are not taken into account fully. In particular I will highlight the need for true collaboration between humanities and computer science researchers, which has the potential to deliver truly novel insights to both areas.

3 Patrik Svensson: Humanities Computing as Digital Humanities, in: Terras, Nyhann, Vanhoutte (eds.): Defining Digital Humanities, pp. 175-202.

4 Stefan Jänicke et al.: On Close and Distant Reading in Digital Humanities: A Survey and Future Challenges, in: Rita Borgo, Fabio Ganovelli, Ivan Viola: Eurographics Conference on Visualization 2015, pp. 83-103. DOI: https://doi.org/10.2312/eurovisstar.20151113 (last access: 07.02. 2020). 


\section{Opportunities in the Digital Humanities}

DH offers a vast range of new tools and methods that could be used to augment non-computational research methods, which can be bewildering as it is often difficult to decide where to start. There have been various calls to humanities researchers to embrace digital tools and methods in their working routine, most of these have either been very high-level or alternatively contain a specific selection of tools and methods used to demonstrate the value of adding digital. ${ }^{5}$ Here I will attempt to achieve a compromise between these two approaches. Identifying two major areas where adding digital methods have the potential to significantly alter the research process - data access and data volume - while illustrating the advantages provided by each area through a selection of tools or methods.

\subsection{Data Access}

The data sources for humanities research are primarily archives, libraries, and museums - with a few exceptions such as archaeology, which requires venturing out into the world. As a result non-computational ${ }^{6}$ humanities research first requires identifying those physical archives that are of relevance to the research and then physically visiting them to discover the relevant objects. The interaction with the objects in the archive will generally be mediated through the archivist or librarian and rely on indexing tools such as card catalogues. Findings in the archive are noted and then at a later time, in the office the notes are analysed, and the research outputs generated. At this point in time if there is information missing in the notes, a repeat visit to the physical archive would be necessary. The physicality of this process and the time (and financial) costs of visiting the archive necessitate very careful planning and note-taking, but also place an intrinsic limit on the amount of material that can be sighted in the archive within the given time-span, meaning that careful sampling is the only viable way to get representative data.

5 Kathleen Fitzpatrick: The Humanities, Done digitally, in: The Chronicle of Higher Education. https://www.chronicle.com/article/The-Humanities-Done-Digitally/127382 (last access: 07.02. 2020); Ted Underwood: Dear Humanists: Fear Not the Digital Revolution, in: The Chronicle of Higher Education 2019. https:/www.chronicle.com/article/Dear-Humanists-Fear-Not-the/245 987/ (last access: 07.02.2020).

6 One of the difficulties in comparing DH work with humanities research that does not use digital tools or methods is how to label that kind of research without judgement. For this reason I will refer to that kind of research as non-computational, to distinguish it from $\mathrm{DH}$ research that $\mathrm{u}$ ses digital or computational methods. 
The digitisation of archives' holdings over the last few decades and their availability via online portals represents a step-change in how archival research can be undertaken. ${ }^{7}$ Depending on the type of materials involved, this might include photographs of the objects and associated meta-data or, in the case of text documents such as books or letters, full text generated through Optical Character Recognition (OCR) or manual transcription. Search engines are then used to index these data and the research can now enter one or more search keywords and retrieve all objects that share these keywords. The researcher can then download the results to their own computer for future analysis.

This represents a number of major changes to the humanities research flow. First, the requirement to physically visit the source archives is reduced, as much content is now available digitally. Second, it is now possible to refer to a digital representation of the actual source material during the analysis and write-up, rather than being restricted to the notes made at the archive. Third, if during the analysis it becomes clear that additional data are needed, it is now significantly easier to acquire this. At the same time relying purely on digital archives does introduce new sources of data uncertainty that will be discussed later.

\subsubsection{Technological underpinnings}

The technology underpinning digital archives is Information Retrieval (IR). ${ }^{8}$ IR focuses on quickly finding things that satisfy the information need of a user and has four core concepts: the documents that can be searched for, the keywords used to index the documents, the search keywords provided by the user, and the relevance of each document with respect to the search keywords. Important to note is that the concept of a document is used to describe any kind of thing that is indexed by the IR system, regardless of whether this is fulltext, images, or just meta-data.

To achieve high retrieval performance the data-set within which the user can search is first pre-processed and each document is indexed with one or more keywords that describe the document. After indexing the user can formulate their information need as one or more search keywords. The information retrieval system then uses the index keywords to retrieve those documents that best match the search keywords.

7 Kimberly Barata: Archives in the digital age, in: Journal of the Society of Archivists 25.1 (2004), pp. 63-70; Bob Nicholson: The Digital Turn: Exploring the methodological possibilities of digital newspaper archives, in: Media History 19.1 (2013), pp. 59-73.

8 Ricardo Baeza-Yates, Berthier Ribeiro-Neto: Modern Information Retrieval, 2nd ed., Harlow et. al. 2011. 
In this process there are two main areas that are of relevance to the humanities researcher, as they influence what the researcher is shown for their search keywords. First, how the input data are pre-processed to generate the keywords describing each document and second, the way in which the 'relevance' of a document with respect to the search keywords is calculated.

In pre-processing the document is split into individual keywords using a language model in order to determine where the boundaries between keywords are. For example such a model knows that 'keyword-search' is a compound noun, which in the index should not be split into two. Because the search system uses exact matching ${ }^{9}$ between search and document keywords, to ensure performance, the tokens are generally further processed in the index to increase the likelihood of the two matching. ${ }^{10}$ Stemming or lemmatisation are common techniques, which reduce variants of the same word to a single variant. For example 'house', 'houses', and 'housing' would all be reduced to 'house'. The same is applied to the search keywords, with the effect that a search for 'house' also returns documents that refer to the plural or to the verb form. This increases the number of documents returned (also known as the recall), but also increases the number of documents that are found that are not relevant (what is known as a loss of precision). However, it is important to note that a further manual inspection of the results is necessary to ensure that the retrieved documents actually match the specific variant of the word that the researcher was looking for, as the results will contain all variants, regardless of how the user spelled the word in the query.

When the user then searches, the systems matches the query to document keywords and most current IR systems will also attempt to rank the matching documents by how relevant they are to the query keywords. To achieve this, each keyword is given a score for each document it appears in. Then, when searching the scores for each query keywords are combined per document and then the documents ranked by that score. One of the most successful scoring formulas is BM25, ${ }^{11}$ which has been extended in the past to achieve the quality seen in modern search systems ${ }^{12}$, but the fundamental principle as covered here remains the same. Documents are ranked by measuring how often a se-

9 There are of course also fuzzy approaches to matching query and document keywords, but those are deployed and used infrequently.

10 Safaa I. Hajeer, et al.: A New Stemming Algorithm for Efficient Information Retrieval Systems and Web Search Engines, in: Aboul E. Hassanien, et al. (eds.): Multimedia Forensics and Security. Foundations, Innovations, and Applications, Cham 2017, pp. 117-135.

11 Stephen E. Robertson et al.: Okapi at TREC-3, in: Proceedings of the Third Text REtrieval Conference, Gaithersburg 1995, pp. 109-126.

12 Sergio Jimenez et al.: BM25-CTF: Improving TF and IDF factors in BM25 by using collection term frequencies, in: Journal of Intelligent \& Fuzzy Systems 34.1 (2018), pp. 1-13. 
arch keyword appears in a single document and also how often it appears across all documents. A relevant keyword for a document is a keyword that appears frequently in that document and only in few other documents. It is relevant, because it distinguishes the document from all other documents. The list of documents that match the user's query is then sorted by these relevance values and the user is shown 1-10 of 10,000 documents, but again it is often necessary to page through all the results, as this technical 'relevance' might not match the semantic relevance desired by the researcher.

\subsection{Volume of Data}

The second major aspect in which $\mathrm{DH}$ research distinguishes itself from noncomputational humanities research is the amount of data that can be used as part of the research. ${ }^{13}$ Non-computational, manual analysis imposes a temporal upper bound as to how much time can be invested and thus how much data can be analysed. The use of digital tools does not alter the amount of time that can be invested in the manual analysis. However, the DH methods allow a much larger data-set to be automatically processed, the results of which can then be analysed manually.

Methods for dealing with large text data-sets are commonly described as 'distant reading' ${ }^{14}$ and that term has slowly expanded to sometimes being used to label any kind of large-scale, quantitative analysis of digital humanities data - irrespective of whether that is an appropriate extension of the term. ${ }^{15}$ Before briefly looking at some of these methods, it needs to be said that while the term distant reading is frequently used, it is misleading as none of these methods actually 'read' the data they are provided with. Instead all these techniques take the source data, apply a variety of processing steps which result in a series of quantitative data, and from these statistical measures of the data can be produced that can then be interpreted. This does not invalidate the methods, it is just important to not take the label to literally.

Techniques for dealing with large scale textual data tend to be based on word counts, either just counting individual words or counting cooccurrences. In both cases the text is initially split into words, using a language

13 Christoph Schöch: Big? Smart? Clean? Messy? Data in the Humanities, in: Journal of Digital Humanities 2.3 (2013), pp. 2-13.

14 Franco Moretti: Distant Reading, London 2013. Other terms such as 'zoom' / 'zooming' have also been used, but this is the one that has become most widespread.

15 Ted Underwood: A Genealogy of Distant Reading, in: DHQ: Digital Humanities Quarterly 11.2 (2017). http://www.digitalhumanities.org/dhq/vol/11/2/000317/000317.html (last access: 07.02.2020). 
model as described earlier. Then for individual word counts, these are simply calculated. For the co-occurrence models, whether two words co-occur is then calculated by moving a window over the text. ${ }^{16}$ Two words are then calculated to co-occur if they appear within the window, in other words, if they appear within a certain distance of each other in the text. While the exact size of the window - the number of words within which words are defined to co-occur varies depending on the context, ten words is commonly used as a window size. The individual counts and co-occurrence values form the basis for three commonly used methods: topic modelling, vector-space models, and more general machine-learning methods.

\subsubsection{Topic Modelling}

Amongst the various topic modelling algorithms, Latent Dirichlet Allocation $(\mathrm{LDA}){ }^{17}$ is one of the most commonly used techniques, but most other algorithms take a similar approach. The fundamental idea behind the topic models is that topics are made up of words, with each word having a likelihood attached that defines how important it is for the topic. Next, a document is seen as a collection of topics in the same way, again with each topic having a likelihood attached to define how much of the document it represents. Finally, the words we see in the text are assumed to have been selected through a random selection of topics and then randomly selecting words from the topics, the random selection being weighted by the topic and word likelihoods.

As it is unknown what exactly the topics are and how they appear in the document, the topic modelling algorithms use the observed co-occurrence data to automatically infer the topic to word and document to topic likelihoods. The result is generally a list of topics and then for each topic the researcher is shown the most important words for the topic. These results can then be interpreted manually to analyse the topics that appear in the data-set. ${ }^{18} \mathrm{An}$ important aspect of modern topic modelling algorithms is that they generally assign more than one topic to a document, making it possible to model the nuances of different topics co-existing in a document.

16 Romain Vuillemot et al.: What's Being Said Near "Martha"? Exploring Name Entities in Literary Text Collections, in: IEEE Symposium on Visual Analytics Science and Technology, Atlantic City 2009, pp. 107-114.

17 David M. Blei, Andrew Y. Ng, Michael I. Jordan: Latent dirichlet allocation, in: The Journal of Machine Learning Research 3 (2003), pp. 993-1022.

18 Jonathan Chang et al.: Reading Tea Leaves: How Humans Interpret Topic Models, in: Advances in Neural Information Processing Systems 22, Vancouver 2009, pp. 288-296. 


\subsubsection{Vector-space models}

Vector-space models come from the information retrieval world, but in the $\mathrm{DH}$ field are mostly used to describe word semantics models like word $2 v_{e c}{ }^{19}$. The idea behind these models is that the meaning of a word can be defined through the words that it co-occurs with. ${ }^{20}$ The underlying co-occurrence data is generally represented as a matrix where each cell in the matrix indicates how often two specific words co-occur. The problem with these matrices is that they are generally very sparse, meaning that most cells in the matrix are zero (as those two words never co-occur). What models like word2vec do is use machine learning algorithms to reduce the number of dimensions in the matrix from many thousands to a few hundred. In the resulting lower dimension models similar words tend to cluster together, thus by comparing the distances between pairs of words in the model, it is possible to determine which words are semantically more or less related.

\subsubsection{Machine learning}

The third approach to dealing with the volume of data is more general, namely artificial neural network (ANN) algorithms, which have become very popular in DH. In ANNs, the starting point is a data-set consisting of pairs of input data and output label. The aim of the ANN training is then to learn how to transform the input data into the output labels. To this end ANNs have three layers. An input layer that represents the data to learn and an output layer that represents the labels you want the ANN to output for the input layer. In between these you have at least one hidden layer that connects the input to the output layer. Each connection between two nodes in the ANN is weighted and each node in the ANN contains a discontinuous function that defines what level of signal has to come over all conceptions from the predecessor nodes in order for this node to activate. The aim of the learning process is then to learn the connection weights and activation functions based on the training data that is provided.

To achieve this, ANNs generally need very large sets of labelled data in order to learn the model. The reason for this is that in the learning process the ANN basically classifies each data-point in the training set and compares the generated classification to the manual labelling. This will include errors, and

19 Tomas Mikolov et al.: Distributed Representations of Words and Phrases and their Compositionality, in: Advances in Neural Information Processing Systems 26, Lake Tahoe 2013, pp. 3111 3119.

20 John R. Firth: A Synopsis of Linguistic Theory, in: Studies in Linguistic Analysis, Oxford 1957, pp. 1-32. 
where the model makes mistakes, corrections for the mistake are applied starting from the output layer, moving through the hidden layers, until we get to the input layer, a process known as back-propagation. This learning process is repeated multiple times until the error rate stabilises.

One of the biggest risks with training ANN models is 'overfitting. ${ }^{21}{ }^{21}$ Overfitting means that the algorithm learns a model that fits the training data very precisely, but which if given data that it has not seen before, makes huge mistakes. To address this, the learning process is generally given a second data-set, the so-called 'test' data, which after a number of iterations of the learning process is used to evaluate the model. This allows the learning process to determine when it is no longer improving the quality of the model and is in risk of overfitting. It does this by looking at whether the classification accuracy of the model decreases as the model is trained. If the accuracy no longer decreases, then the model has been overfitted and training should be stopped and the previous model used as the final model.

All these techniques open up humanities research to working with amounts of data that exceed what can be handled manually, but by increasing the distance between the researcher and the source material, they introduce new error sources into the research process, which will be discussed below.

\section{Risks in the Digital Humanities}

As illustrated above, digital tools offer new opportunities, but they also come with significant new risks. The rise in the amount of data and range of new methods that can be used in $\mathrm{DH}$ has been accompanied by a significant amount of work focused on a critical analysis of DH itself. Initially much of this focused on the question of balance between theory and practice. ${ }^{22}$ To that the discussion then added a focus on issues around cultural criticism aspects of

21 Tom Dietterich: Overfitting and Undercomputing in Machine Learning, in: ACM Computing Surveys 27.3 (1995), pp. 326-327; Nitish Srivastava et al.: Dropout: A Simple Way to Prevent Neural Networks from Overfitting, in: The Journal of Machine Learning Research 15.1 (2014), pp. 1929-1958.

22 Andrew Prescott: Making the Digital Human: Anxieties, Possibilities, Challenges, in: Digital Riffs 2012. http://digitalriffs.blogspot.com/2012/07/making-digital-human-anxieties.html (last access: 21.06.2019); Tibor Koltay: Library and information science and the digital humanities: Perceived and real strengths and weaknesses, in: Journal of Documentation 72.4 (2016), pp. 781-792; Bethany Nowviskie: On the Origin of "Hack" and "Yack", in: Matthew K. Gold, Lauren F. Klein (eds.): Debates in the Digital Humanities, Minneapolis 2016, pp. 66-70; Tanya E. Clement, Daniel Carter: Connecting theory and practice in digital humanities information work, in: Journal of the Association for Information Science and Technology 68.6 (2017), pp. 1385-1396. 
$\mathrm{DH}$ research. ${ }^{23}$ All of these make very good points and particularly the issues around cultural criticism in DH research remain largely unaddressed, but the one thing all of these overlook are risks to $\mathrm{DH}$ research caused by methodologically poor use of the available data, tools, and methods. However, unlike work such as Da's critical analysis of computational literature studies ${ }^{24}$, I intend to give a broader overview over methodological issues, rather than analysing a specific area in depth.

The risks presented here are indicative of how the digital aspects are being used by researchers and are not inherent in the digital aspects themselves. Thus, their existence does not imply that the $\mathrm{DH}$ field should be abandoned in whole or even in parts, only that the field needs to become more aware of these issues and incorporate them into its research practices. As such any examples selected in this section are to be treated as exemplars of a general trend, not specifically failing projects.

\subsection{Data-driven Weaknesses}

The first and most common methodological weakness that I want to address is missing criticism or critical analysis of the data-sets based on which the research is conducted. As discussed above, in non-computational humanities research a manual selection of a sub-set of the available data is always necessary to allow the research to be completed in a realistic time-frame. At the same time, it is also known that the selection processes are influenced by social and economic pressures, as the gender and colonial-studies research show. Due to this a critical analysis of the sources and the selection process have historically been a core aspect of humanities research and work in recent times on gender and colonial aspects have pushed this ever more into the foreground. ${ }^{25}$

23 Alan Liu: Where is Cultural Criticism in the Digital Humanities?, in: Gold: Debates, pp. 490509; Gerben Zaagsma: On Digital History, in: BMGN - Low Countries Historical Review 128.4 (2013), pp. 3-29; David Berry et al.: No Signal without Symbol: Decoding the Digital Humanities, in: Matthew K. Gold, Lauren F. Klein (eds.): Debates in the Digital Humanities, Minneapolis 2019. https://dhdebates.gc.cuny.edu/projects/debates-in-the-digital-humanities-2019 (last access: 07.02 .2020 ).

24 Nan Z. Da: The Computational Case against Computational Literary Studies, in: Critical Inquiry 45.3 (2019), pp. 601-639.

25 Jenny Bergenmar, Katarina Leppänen: Gender and Vernaculars in Digital Humanities and World Literature, in: NORA - Nordic Journal of Feminist and Gender Research 25.4 (2017), pp. 232-246; Roopika Risam: Decolonizing Digital Humanities in Theory and Practice, in: Jentery Sayers (ed.): The Routledge Companion to Media Studies and Digital Humanities, New York 2018, pp. 98-106. 
In the DH this critical analysis of the data-sources and their potential biases has taken a back-seat. As DH algorithms allow the analysis of very large collections of objects, there is a perception that it is no longer a necessity to select a sub-set, instead 'everything' that is available can be fed into the algorithm. It seems that as a consequence the question of how the collection that is being analysed has been created is barely considered or completely ignored.

All the texts in the corpus must, at the time of their initial collection, have been judged to be sufficiently worthy to be included in a library or archive somewhere. Then, the texts will have to have survived two world wars, a period of active book-burning, water damage, theft, and a wide range of other physical risks. Then the texts will have to have been digitised, where a further two hurdles appear. First the texts will have had to have been selected for digitisation. Digitisation is both a time and financially expensive process, it is thus generally impossible to digitise the whole collection in one go and selections have to be made. In the ideal case, the selection is done topically or temporally to minimise bias, but at the beginning of the process or where third-party funding is used for the digitisation, the focus is generally on the 'important' or 'valuable' works, as these make it easier to argue that the digitisation is worthwhile.

The final step is the transformation of the scanned images into text (where appropriate). Due to the scale of the task, automated processes such as Optical Character Recognition have to be employed. ${ }^{26}$ As the OCR output is heavily dependent on the quality of the print, the typesetting, and the age of the text ${ }^{27}$, texts that can be processed successfully tend to be processed first.

Due to all these reasons the digital source is already biased in a way that can make it quite hard to pin down exactly how strong the bias is, before we even look at finding the objects that make up the analysis data-set. Consider the German text corpus available via the Deutsches Textarchiv. ${ }^{28}$ Unlike other online corpora they provide some information online about the content of the archive and how it was curated, giving some indication of potential biases. However, even there the level of detail is limited ('selected bibliographies', 'specialist recommendations') and they explicitly state that the initial focus was

26 Ahmad P. Tafti et al.: OCR as a Service: An Experimental Evaluation of Google Docs OCR, Tesseract, ABBYY FineReader, and Transym, in: George Bebis et al. (eds.): Advances in Visual Computing, Cham 2016, pp. 735-746.

27 Florian Fink, Klaus U. Schulz, Uwe Springmann: Profiling of OCR'ed Historical Texts Revisited, in: Proceedings of the 2nd International Conference on Digital Access to Textual Cultural Heritage, Göttingen 2017, pp. 61-66.

$28 \mathrm{http}: / /$ www.deutschestextarchiv.de/, selected as an example because they actually provide some information on its creation (last access: 07.02.2020). 
on canonical works, with selected additions. ${ }^{29}$ What was selected and why is not clear, but focusing on the canonical works will introduce significant bias in the data, regardless of what was added.

All of these issues should not really create an issue for humanities research, as the selection of sources and the critical analysis of these sources and the selection process is a core research concept. However, in the $\mathrm{DH}$ area, the whole process is frequently summarised as "a query for the topic empire was used and a total of 843 texts returned, which were downloaded in TEI and form the basis of the analysis" or "we acquired the corpus of letters sent by X". While there might have been critical engagement with the archive and a number of actual query keywords might have been used to get good coverage over the given topic, no details are given on this process, even though they might significantly skew the distribution of texts in the analysis corpus.

To undertake methodologically sound $\mathrm{DH}$ research, these methodological aspects need to be reported in detail. Where the required information is not available within the archive, an analysis of potential biases in the corpus should be undertaken and reported. A positive example is the work by Müller, where the digital source is analysed in detail to understand its specific attributes, these and the methods used are reported in detail, and where necessary reference is made back to the original physical source. ${ }^{30}$ Without this detail, any conclusion that goes beyond "in the specific set of texts we analysed" cannot be relied upon, not because the conclusion is right or wrong, but because we have no idea of how the specifics of the data skew the analysis.

\subsection{Algorithms are opinionated ${ }^{31}$}

Computer Science's roots lie in mathematics and in particular in the field of boolean logic. Boolean logic holds that for any given question there can only be two possible answers: true or false. At the technical level, a computer is a collection of transistors which implement exactly this logic decision and where the combination of millions of these transistors allow us to implement the kind of complex logic flows that make DH happen.

29 Alexander Geyken et al.: Das Deutsche Textarchiv: Vom historischen Korpus zum aktiven Archiv, in: Silke Schomburg et al. (eds.): Digitale Wissenschaft. Stand und Entwicklung digital vernetzter Forschung in Deutschland, Köln 2011, pp. 157-161.

30 Andreas Müller: Vom Konversationslexikon zur Enzyklopädie, in: Das Achtzehnte Jahrhundert 43.1 (2019), pp. 73-89.

31 For an early treatment of this see David Sculley, Bradley M. Pasanek: Meaning and Mining: the Impact of Implicit Assumptions in Data Mining for the Humanities, in: Literary and Linguistic Computing 23.4 (2008), pp. 409-424. 
This fundamental binary view of the world extends into all algorithms, as even where they are designed to support uncertainty, this is always simulated and fundamentally reduced to a binary representation. The effect of this is that algorithms generally are incapable of modelling when they cannot answer a question. An algorithm will always provide an 'answer' to a question, fundamentally splitting the set of input data elements into those for which the question is true and those for which it is not. This happens even if the data that is fed into the algorithm is not of the appropriate type or fulfils the constraints set be the algorithm.

The most common example of these kinds of mistakes is the use of fundamental statistical measures (which are also algorithms). Where quantitative results, for example frequencies of word co-occurrences, are calculated, the results for different conditions, for example words that co-occur with male vs. female characters, are often compared using Student's t-tests to prove that they are significantly different. However, the t-test requires that the measurements being compared are independent and normally distributed. Neither of these two are likely to be the case for the results of text analysis. Unlike for example the height of trees in two separate forests, the frequencies of words in a single text are possibly to be linked together quite strongly, breaking the independence assumption. Secondly, word distributions are generally more likely to follow a Zipf distribution, ${ }^{32}$ breaking the normal distribution assumption. Now this might not be the case for a specific piece of research, say because the word counts have been drawn from unrelated texts and they happen to be normally distributed, but this needs to be reported. Otherwise any statistical significance is meaningless and any research conclusions drawn from it are as likely to be false as true, fundamentally invalidating any conclusions.

In addition to this fundamental bias towards always providing an answer, algorithms can also have specific opinions that may not be immediately visible. This is particularly the case for many of the machine-learning models that have become very popular in the recent years. As explained above machine-learning models take large amounts of manually annotated data and try to learn how to map the input to the desired annotation. While the results are often very promising, the difficulty is that it is unclear what has been learned. One of the classic examples are neural networks trained on the ImageNet data-set to recognise a wide range of objects. They work very well, but what researchers then found was that by manipulating small aspects of the objects in the images, they could get the neural network to completely misidentify the images. For example by making minute changes to the texture of an image of a turtle,

32 George K. Zipf: Human Behavior and the Principle of Least Effort, Cambridge, Mass. 1949, p. 24. 
changes so small they are barely noticeable to a human, they could induce the neural network to recognise the image as an automatic rifle. ${ }^{33}$ The problem arises because the neural network has actually learned to distinguish different texture patterns and image features that are often barely visible to the human eye. While for the data it was trained on this works, with unknown or slightly different data it quickly produces erroneous results.

This illustrates the susceptibility of neural networks nicely, but what is primarily relevant for $\mathrm{DH}$ is the factor that it is not clear what the neural networks are learning, thus it is not clear what their 'opinion' of the data is. For example the same neural network for image classification can be used to cluster historic photographs. ${ }^{34}$ The results look very promising, but because we don't know what the model has learned, we don't know whether the results represent what we, as humans, see in the data (a clustering by image type: portrait, group photo, architecture, etc.) or some underlying bias. For example, because the technology used in photography changes over time, the neural network might actually be clustering the images based on technical aspects of the photographs, because it is picking up on variations caused by different cameras, film materials, or development processes. While this might coincide with different subject types, making the results look appropriate, when further images are added, that use, for example, the same film material in a different setting, it is possible that the algorithm would completely misclassify the images. As in the case of the data biases, it is not so much the existence of the bias that is the issue, but the fact that it is not clear whether there is any and what kind of bias is included.

\subsection{Evaluation}

Unlike non-computational humanities research, where the argument is the research output, in digital humanities research there is an intermediate step of data-generation and the research output is derived through interpretation from the data. Because this intermediate data-generation step is undertaken using an algorithm, it is necessary to evaluate the accuracy and correctness of the algorithm, before and independently from the conclusions drawn from its output. The biggest methodological weakness around evaluation is that in most pieces of digital humanities research it is missing. Two reasons for this are that

33 Anish Athalye et al.: Synthesizing Robust Adversarial Examples. arXiv preprint arXiv:1707.07 397 (2017).

34 Peter Leonard: Lina Jonns Efterträdare: Machine Vision and Lund's Photographic History, in: Book of abstracts 4th Conference of The Association Digital Humanities in the Nordic Countries, Copenhagen 2019. https://cst.dk/DHN2019Pro/DHN2019BookofAbstracts.pdf (last access: 07.02.2020). 
evaluating takes time and that assessing the algorithm's output with respect to the research question is conceptually mistaken for the act of evaluating the algorithm.

An area where this type of mistake is often seen is where topic modelling is used. In many cases only a selection of topics is actually reported on, detailing how they support the original hypothesis. However, if we generate random lists of words that frequently co-occur, there is likely to be at least a few lists which can be interpreted relative to the research question. This does not mean that the model as a whole is valid, as is never the case for a random sample. If the five or six reported topics are the only understandable ones out of a model with 30 topics, then this is not a good model and no conclusions should be drawn based on such a small selection. This, as Da points out, also goes for negative results. Only if it is clear that the negative results are not just random noise can any conclusions be drawn.

Correctly evaluating the algorithm means testing it with a range of input data and then assessing whether the output produced by the algorithm is correct for the given input, irrespective of the research question. In addition to not taking the research question into consideration, two basic rules need to be followed.

First, the algorithm must never be evaluated using the data it was trained on. This does not just mean splitting the data-set into a learning and an evaluation data-set, it means choosing an evaluation data-set that is drawn from a different source than the learning data-set. This is necessary, as even if the original data-set is randomly split into a learning and an evaluation data-set, there are likely to be underlying characteristics of the data-set that distinguish the data-set from all others and which introduce bias into the algorithm that limits its generalisability. By choosing an independent evaluation data-set, it is possible to fully test the degree to which the algorithm generalises.

During the development and evaluation of the algorithm the learning dataset is itself split into a training and a test data-set. When testing with the test data, the generated output can be compared against the expected outcome and can be used to improve the algorithm. However, when evaluating using the evaluation data, only accuracy or correctness metrics may be generated. The results of evaluation run must not be used to further improve the algorithm, as in that case the evaluation data is no longer separate from the training data, negating the benefits of the separate evaluation data-set.

The second basic rule is that the evaluation must be designed to counteract any known biases in the data. If, for example, the aim is to develop an algorithm that can classify text for the whole $19^{\text {th }}$ century, then the evaluation data must be selected to provide even coverage over the target time period, even if 
the training set has a bias towards texts later in the period. This is necessary, as otherwise the evaluation results do not provide a realistic assessment of the algorithm quality.

As part of this we should also become more open to reporting negative results. While this is something most disciplines struggle with, the humanities with their predisposition for critical self-analysis should really be primed for leading on this.

\section{The Spectre of Techno-Positivism}

In the sections above I have discussed what I see as both the opportunities and main risks facing the Digital Humanities at this point in time. However, the biggest risk I see in the future of the Digital Humanities is that as a discipline we drift into what I term 'techno-positivism'. We build more and more digital archives, digital editions, and many other kinds of data-sets. We apply digital methods to the data-sets, we visualise and then describe the results. What we don't do on a large scale is critically engage with the data or the results. Our algorithms are not grounded in humanities theories, our results are barely contextualised based on existing knowledge. We are undertaking essentially positivist research, but hide that truth under large amounts of data, interactive interfaces, and fancy visualisations.

If, as a discipline, we do not address these issues, then we are complicit in dragging research back into the past, where gender, colonialism, canonisation, and related issues are ignored, where the Digital Humanities are the study of dead, white dudes ${ }^{35}$. This risk is significant, as this kind of research is sufficiently simplistic that it can be supported with current tools and algorithms. However, it also means that significant amounts of current Digital Humanities research should be labelled as interesting, but the results do not allow generalise to anything that was not in the analysed data, and no general conclusions can be drawn.

However, unlike other critical commentators I do not argue that the Digital Humanities should be abandoned. Quite apart from the fact that the popularity of $\mathrm{DH}$ with funding bodies makes this a ludicrous idea, I believe that addressing these things head-on will actually allow $\mathrm{DH}$ research to fully achieve its potential. The current, techno-positivist approach allows the humanities researcher to create the data, which is then handed to the computer scientist for processing, and the results are interpreted by the humanities researcher. While

35 Lisa Marie Rhody: Why I Dig: Feminist Approaches to Text Analysis, in: Gold, Klein: Debates, pp. 536-539; Kim Gallon: Making a Case for the Black Digital Humanities, in: ibid., pp. 42-49. 
this represents basic working together, it is not true collaboration. True collaboration requires an in-depth understanding of what the other does in order to truly benefit from their input and in order to provide responses back that allow the other to fully understand the value and nuances of the own work.

This level of collaboration will require computer scientists to develop algorithms that are grounded in complex theoretical humanities frameworks developed by humanities researchers. That see the world as more than a collection of word frequencies, collocations, and pixel colours. It will also require humanities scholars to fully understand the power and limitations of these algorithms, so that they can properly contextualise them and place the results in larger frameworks of understanding. This has significant benefits to both sides.

First, for computer scientists it will drive the development of truly novel algorithms that are able to model the complexities of reality, rather than just reducing reality until it fits into simple models. This will address the sometimes voiced question of why a computer scientist is needed on a project. Second, for humanities researchers it will produce truly novel methods, rather than simplistically scaled-up versions of the counting methods that were introduced by and popular in positivist research. This will allow humanities researchers to pose new research questions, rather than just technically rehashing basic questions. It might mean that results are possibly produced not quite as quickly, but it will produce results that have true value.

This can be achieved and we are seeing the slow drip-drip-drip of research taking these issues into account, but to truly achieve the aim of $\mathrm{DH}$ being a transformative new approach, we need to stop fooling ourselves that current computational methods achieve even close to the depth of non-computational humanities research methods. Counting words is not reading text. Applying machine learning is not understanding. The focus needs to move from what is technically possible to how we can transfer at least parts of humans' deeper understanding of these issues to the algorithmic world. Then DH will be truly transformational.

"The first principle is that you must not fool yourself-and you are the easiest person to fool. So you have to be very careful about that. After you've not fooled yourself, it's easy not to fool other scientists. You just have to be honest in a conventional way after that." Richard P. Feynmann, Caltech Commencement Address, 1974 


\section{Acknowledgements}

I would like to thank my colleagues at the Digital Humanities Meetup in Halle for the many constructive discussions that helped focus my thinking around these methodological issues. I would like to particularly thank Andreas Müller and Thorsten Roeder for the constructive feedback that has significantly improved this article.

\section{References}

Anish Athalye et al.: Synthesizing Robust Adversarial Examples. arXiv preprint arXiv:1707.07397 (2017).

Ricardo Baeza-Yates, Berthier Ribeiro-Neto: Modern Information Retrieval, 2nd ed., Harlow et. al. 2011.

Kimberly Barata: Archives in the digital age, in: Journal of the Society of Archivists 25.1 (2004), pp. 63-70.

Jenny Bergenmar, Katarina Leppänen: Gender and Vernaculars in Digital Humanities and World Literature, in: NORA - Nordic Journal of Feminist and Gender Research 25.4 (2017), pp. 232-246.

David Berry et al.: No Signal without Symbol: Decoding the Digital Humanities, in: Matthew K. Gold, Lauren F. Klein (eds.): Debates in the DigitalHumanities, Minneapolis 2019. https://dhdebates.gc.cuny.edu/projects/debates-in-the-digital-humanities-2019.

David M. Blei, Andrew Y. Ng, Michael I. Jordan: Latent dirichlet allocation, in: The Journal of Machine Learning Research 3 (2003), pp. 993-1022.

Jonathan Chang et al.: Reading Tea Leaves: How Humans Interpret Topic Models, in: Advances in Neural Information Processing Systems 22, Vancouver 2009, pp. 288-296.

Tanya E. Clement, Daniel Carter: Connecting theory and practice in digital humanities information work, in: Journal of the Association for Information Science and Technology 68.6 (2017), pp. 1385-1396.

Nan Z. Da: The Computational Case against Computational Literary Studies, in: Critical Inquiry 45.3 (2019), pp. 601-639.

Tom Dietterich: Overfitting and Undercomputing in Machine Learning, in: ACM Computing Surveys 27.3 (1995), pp. 326-327.

Florian Fink, Klaus U. Schulz, Uwe Springmann: Profiling of OCR'ed Historical Texts Revisited, in: Proceedings of the 2nd International Conference on Digital Access to Textual Cultural Heritage, Göttingen 2017, pp. 61-66.

John R. Firth: A Synopsis of Linguistic Theory, in: Studies in Linguistic Analysis, Oxford 1957, pp. 1-32.

Kathleen Fitzpatrick: The Humanities, Done Digitally, in: Matthew K. Gold (ed.): Debates in the Digital humanities, Minneapolis 2012, pp. 12-15.

Kathleen Fitzpatrick: The Humanities, Done digitally, in: The Chronicle of Higher Education. https://www.chronicle.com/article/The-Humanities-Done-Digitally/127382. 
Kim Gallon: Making a Case for the Black Digital Humanities, in: Matthew K. Gold, Lauren F. Klein (eds.): Debates in the Digital Humanities, Minneapolis 2016, pp. 42-49.

Alexander Geyken et al.: Das Deutsche Textarchiv: Vom historischen Korpus zum aktiven Archiv, in: Silke Schomburg et al. (eds.): Digitale Wissenschaft. Stand und Entwicklung digital vernetzter Forschung in Deutschland, Köln 2011, pp. 157-161.

Safaa I. Hajeer et al.: A New Stemming Algorithm for Efficient Information Retrieval Systems and Web Search Engines, in: Aboul E.Hassanien et al. (eds.): Multimedia Forensics and Security. Foundations, Innovations, and Applications, Cham 2017, pp. 117-135.

Stefan Jänicke et al.: On Close and Distant Reading in Digital Humanities: A Survey and Future Challenges, in: Rita Borgo, Fabio Ganovelli, Ivan Viola: Eurographics Conference on Visualization 2015, pp. 83-103. DOI: https://doi.org/10.2312/eurovisstar.20151113.

Sergio Jimenez et al.: BM25-CTF: Improving TF and IDF factors in BM25 by using collection term frequencies, in: Journal of Intelligent \& Fuzzy Systems 34.1 (2018), pp. 1-13.

Matthew G. Kirschenbaum: What is Digital Humanities and What's It Doing in English Departments, in: Matthew K. Gold (ed.): Debates in the Digital humanities, Minneapolis 2012, pp. 3-11.

Tibor Koltay: Library and information science and the digital humanities: Perceived and real strengths and weaknesses, in: Journal of Documentation 72.4 (2016), pp. 781-792.

Peter Leonard: Lina Jonns Efterträdare: Machine Vision and Lund's Photographic History, in: Book of abstracts 4th Conference of The Association Digital Humanities in the Nordic Countries, Copenhagen 2019. https://cst.dk/DHN2019Pro/DHN2019BookofAbstracts. pdf.

Alan Liu: Where is Cultural Criticism in the Digital Humanities?, in: Matthew K. Gold (ed.): Debates in the Digital humanities, Minneapolis 2012, pp. 490-509.

Tomas Mikolov et al.: Distributed Representations of Words and Phrases and their Compositionality, in: Advances in Neural Information Processing Systems 26, Lake Tahoe 2013, pp. 3111-3119.

Franco Moretti: Distant Reading, London 2013.

Andreas Müller: Vom Konversationslexikon zur Enzyklopädie, in: Das Achtzehnte Jahrhundert 43.1 (2019), pp. 73-89.

Bob Nicholson: The Digital Turn: Exploring the methodological possibilities of digital newspaper archives, in: Media History 19.1 (2013), pp. 59-73.

Bethany Nowviskie: Digital Humanities in the Anthropocene, in: Digital Scholarship in the Humanities 30.1 (2015), pp. i4-i15.

Bethany Nowviskie: On the Origin of "Hack" and "Yack", in: Matthew K. Gold, Lauren F. Klein (eds.): Debates in the Digital Humanities, Minneapolis 2016, pp. 66-70.

Andrew Prescott: Making the Digital Human: Anxieties, Possibilities, Challenges, in: Digital Riffs 2012. http://digitalriffs.blogspot.com/2012/07/making-digital-human-anxieties.

Lisa Marie Rhody: Why I Dig: Feminist Approaches to Text Analysis, in: Matthew K. Gold, Lauren F. Klein (eds.): Debates in the Digital Humanities, Minneapolis 2016, pp. 536539.

Roopika Risam: Decolonizing Digital Humanities in Theory and Practice, in: Jentery Sayers (ed.): The Routledge Companion to Media Studies and Digital Humanities, New York 2018, pp. 98-106. 
Stephen E. Robertson et al.: Okapi at TREC-3, in: Proceedings of the Third Text REtrieval Conference, Gaithersburg 1995, pp. 109-126.

Christoph Schöch: Big? Smart? Clean? Messy? Data in the Humanities, in: Journal of Digital Humanities 2.3 (2013), pp. 2-13.

David Sculley, Bradley M. Pasanek: Meaning and Mining: the Impact of Implicit Assumptions in Data Mining for the Humanities, in: Literary and Linguistic Computing 23.4 (2008), pp. 409-424.

Nitish Srivastava et al.: Dropout: A Simple Way to Prevent Neural Networks from Overfitting, in: The Journal of Machine Learning Research 15.1 (2014), pp. 1929-1958.

Patrik Svensson: Humanities Computing as Digital Humanities, in: Melissa Terras, Julianne Nyhann, Edward Vanhoutte (eds.): Defining Digital Humanities, London/New York 2016, pp. 175-202.

Ahmad P. Tafti et al.: OCR as a Service: An Experimental Evaluation of Google Docs OCR, Tesseract, ABBYY FineReader, and Transym, in: George Bebis et al. (eds.): Advances in Visual Computing, Cham 2016, pp. 735-746.

Ted Underwood: A Genealogy of Distant Reading, in: DHQ: Digital Humanities Quarterly 11.2 (2017). http://www.digitalhumanities.org/dhq/vol/11/2/000317/000317.html.

Ted Underwood: Dear Humanists: Fear Not the Digital Revolution, in: The Chronicle of Higher Education 2019. https://www.chronicle.com/article/Dear-Humanists-Fear-Notthe $/ 245987 /$.

John Unsworth: What is Humanities Computing and What is Not?, in: Melissa Terras, Julianne Nyhann, Edward Vanhoutte (eds.): Defining Digital Humanities, London/New York 2016, pp. 51-63.

Romain Vuillemot et al.: What's Being Said Near "Martha"? Exploring Name Entities in Literary Text Collections, in: IEEE Symposium on Visual Analytics Science and Technology, Atlantic City 2009, pp. 107-114.

Gerben Zaagsma: On Digital History, in: BMGN - Low Countries Historical Review 128.4 (2013), pp. 3-29.

George K. Zipf: Human Behavior and the Principle of Least Effort, Cambridge, Mass. 1949. 


\section{Die historische Lernspiel-App „Sie heißt jetzt Lotte!“ Chancen, Probleme und Herausforderungen beim Einsatz digitaler Medien im Geschichtsunterricht}

\section{Einleitung}

Durch die umfassenden medialen Veränderungen der letzten Jahrzehnte lässt sich die stetig wachsende Bedeutung von digitalen Medien im Alltag nicht mehr wegdenken. So verändern sich nicht nur die Wissens- und Informationszugänge, sondern auch die Voraussetzungen und Bedingungen, unter denen Lernen stattfindet. ${ }^{1}$ Im Folgenden sollen daher die Chancen, Probleme und Herausforderungen beim Einsatz digitaler Medien im Geschichtsunterricht genauer beleuchtet werden, indem das digitale Bildungsprojekt „Sie heißt jetzt Lotte!" exemplarisch in die historische Bildungsarbeit eingebettet wird.

Am 8. März 2012 formulierte die ständige Konferenz der Kultusminister der Länder der Bundesrepublik Deutschland (KMK) den Beschluss zur „Medienbildung in der Schule“ mit dem Ziel, die „Medienbildung als Pflichtaufgabe schulischer Bildung nachhaltig zu verankern sowie den Schulen und Lehrkräften Orientierung für die Medienbildung in Erziehung und Unterricht zu geben. " ${ }^{2}$ Ein KMK-Strategiepapier vom Dezember 2016 beschreibt die Digitalisierung für den gesamten Bildungsbereich als einen Prozess, in dem „digitale Medien und digitale Werkzeuge zunehmend an die Stelle analoger Verfahren treten und diese nicht nur ablösen, sondern neue Perspektiven in allen gesell-

1 Vgl. Ingrid Paus-Hasebrink, Jan-Hinrik Schmidt, Uwe Hasebrink: Zur Erforschung der Rolle des Social Web im Alltag von Heranwachsenden, in: Dies. (Hrsg.): Heranwachsen mit dem Social Web. Zur Rolle von Web 2.0-Angeboten im Alltag von Jugendlichen und jungen Erwachsenen, 2. Auflage, Düsseldorf 2011, S. 13-40, hier S. 16.

2 Kultusministerkonferenz [KMK]: Medienbildung in der Schule, 03/2012. https://www.kmk. org/fileadmin/veroeffentlichungen_beschluesse/2012/2012_03_08_Medienbildung.pdf (letzter Zugriff: 04.09.2019). 
schaftlichen, wirtschaftlichen und wissenschaftlichen Bereichen erschließen." Die Digitalisierung kann daher laut KMK als eine Chance verstanden werden, „formale Bildungsprozesse [...] so zu verändern, dass Talente und Potenziale individuell gefördert werden “4 können. Des Weiteren berge sie natürlich auch eine Reihe von Herausforderungen, da sowohl „die bisher praktizierten Lehrund Lernformen sowie die Struktur von Lernumgebungen überdacht und neugestaltet als auch die Bildungsziele kritisch überprüft und erweitert werden müssen. " ${ }^{5}$ Darüber hinaus müsse der Blick auch auf die schulische Umgebung gelegt werden, indem neue rechtliche, personelle und infrastrukturelle Rahmenbedingungen geschaffen werden müssen. ${ }^{6}$ Der Bildungssektor steht daher vor der Herausforderung, diese Veränderungen in die schulische Lebenswelt zu integrieren.

Der IT-Branchenverband „Bitkom“ kommt jedoch in einer repräsentativen Umfrage mit 503 Lehrkräften der Sekundarstufe I an Hauptschulen, Schulen mit mehreren Bildungsgängen, Realschulen, Gymnasien, Gesamtschulen und Waldorfschulen (12. März 2019) zu dem Ergebnis, dass der Technik-Einsatz in den Schulen häufig aufgrund von fehlenden Geräten und Konzepten sowie aufgrund des mangelnden Know-hows der Lehrkräfte scheitert. Die befragten Lehrkräfte sind der Auffassung, dass Deutschlands Schulen bei der Digitalisierung hinterherhinken (95\%) und wünschen sich eine bessere Aus- und Weiterbildung (85\%) für den Einsatz digitaler Unterrichtsmittel. Die Schulen verfügen laut „Bitkom Research“ lediglich über eine digitale Grundausstattung. Geräte wie Beamer, Whiteboards oder Tablets gibt es lediglich als Einzelgeräte oder in speziellen Fachräumen, was dazu führt, dass nur jede zweite Lehrkraft (49 \%) regelmäßig einen Beamer und nur jede fünfte Lehrkraft (20\%) ein interaktives Whiteboard einsetzt. Tablets hingegen werden nur von $3 \%$ der Lehrkräfte genutzt und das Smartphone kommt bei $90 \%$ der Unterrichtenden nie zum Einsatz. ${ }^{7}$

Es geht also darum, die Digitalisierung im schulischen Kontext neu zu denken, sowohl in Form von infrastrukturellen Verbesserungen als auch, indem die Frage nach einem methodischen und didaktischen Mehrwert gestellt werden muss. Es müssen neue Unterrichtskonzepte erstellt sowie didaktisch und

3 KMK: Strategie der Kultusministerkonferenz „Bildung in der digitalen Welt“, Dez. 2016, S. 3. https://www.kmk.org/fileadmin/Dateien/pdf/PresseUndAktuelles/2017/Strategie_neu_2017_da tum_1.pdf (letzter Zugriff: 05.09.2019).

4 Ebd.

5 Ebd.

6 Vgl. KMK: Strategie der Kultusministerkonferenz „Bildung in der digitalen Welt“, S. 3.

7 Pressebericht von Bitkom Research im Auftrag des Digitalverbands Bitkom: „Lehrer sehen deutsche Schulen digital abgehängt" vom 12.03.2019. https://www.bitkom.org/Presse/Pressein formation/Lehrer-sehen-deutsche-Schulen-digital-abgehaengt (letzter Zugriff: 05.09.2019). 
empirisch erprobt werden; es müssen starre Unterrichtsmethoden aufgebrochen werden und Anwendungsschulungen für die Lehrpersonen stattfinden kurz gesagt, der Unterricht muss sich für neue Medien öffnen und diese sowohl zielsicher als auch kritisch und hinterfragend einsetzen, um zukunftsund anschlussfähig bleiben zu können. ${ }^{8}$

Ein grundlegender Schritt dahin sollte daher bereits zu Beginn der Lehrerinnen- und Lehrerausbildung, also direkt bei den Universitäten und Pädagogischen Hochschulen, ansetzen. Die Realität zeigt jedoch häufig ein anderes Bild, denn sowohl in den Geisteswissenschaften als auch in den Bildungswissenschaften, an denen die Lehrerinnen- und Lehrerausbildung angegliedert ist, gibt es kaum Verknüpfungspunkte zur Informatik - die einzelnen Fachbereiche laufen sich nur selten über den Weg und verharren in ihren jeweiligen Einzeldisziplinen. Sofern es also ein Umdenken geben soll, braucht es viele engagierte Lehrkräfte, die im besten Fall bereits während des Studiums mit den zukünftigen interdisziplinären Herausforderungen konfrontiert und gleichzeitig ermutigt werden, sich diesen mit Offenheit zu stellen. Ziel sollte es sein, einen didaktisch aufbereiteten und methodisch abwechslungsreichen Unterricht zu gestalten, der sich nicht vor neuen Herausforderungen verschließt, sondern die Vorteile der Digitalisierung angemessen in den Schulalltag integriert.

Darüber hinaus stellen sich in der geschichtsdidaktischen Forschung weitere grundlegende Fragen, zum Beispiel: Welche Beiträge die Geschichtsdidaktik zur generellen und domänenspezifischen Medienbildung leisten kann und welche Medienkompetenzen das historische Denken, Lernen und Arbeiten fördern. Gerade dieser Disziplin kommt hier eine besondere Verantwortung $\mathrm{zu}$, gehört doch der Geschichtsunterricht zu den Leitfächern bei der Vermittlung von Medienkompetenz, da sich historisches Lernen immer auch an Medien vollzieht und somit einen kritischen Umgang mit Medien fördert.

Im Folgenden soll daher exemplarisch ein Einblick sowohl in die Möglichkeiten und Chancen als auch in die Risiken und Schwierigkeiten eines digitalen Bildungsprojekts für den Geschichtsunterricht gegeben werden. Es wird zum einen die interdisziplinäre Entwicklung der Lernspiel-App „Sie heißt jetzt Lotte!" thematisiert, indem im ersten Kapitel eine inhaltliche Eingliederung in den historischen Kontext vollzogen wird und die Schnittstellen zum gleichnamigen Film des Bildungsprojektes erörtert werden. Das zweite Kapitel befasst sich mit der anfänglichen Ideenfindung und der interdisziplinären Kommunikation zwischen den Fachbereichen der Neueren und Zeitgeschichte und Geschichtsdidaktik der Universität Erfurt und der Angewandten Informatik der

8 Vgl. KMK: Strategie der Kultusministerkonferenz „Bildung in der digitalen Welt“, S. 5-8. 
Fachhochschule Erfurt. Im dritten Abschnitt werden erste Fortschritte im Spielablauf vorgestellt, die im vierten Kapitel mit dem Betrachten des vorläufigen Projektstands und der weiteren Planungen abgerundet werden. Auf der Grundlage des Projekts wird dann der Versuch unternommen, die LernspielApp aus medienkritischer, fachwissenschaftlicher und fachdidaktischer Sicht einzuordnen, um abschließend die Frage zu klären, ob sich eine Lernspiel-App aus methodischen und didaktischen Blickwinkeln zum heutigen Zeitpunkt bereits problemlos in den schulischen Alltag integrieren lässt.

Es sollte an dieser Stelle vollständigkeitshalber darauf hingewiesen werden, dass aufgrund von eigenen subjektiven Erfahrungen kein vollkommen objektiver Standpunkt in Bezug auf das Projekt und die damit verbundenen Erfahrungen eingenommen werden kann. Die Autorin dieses Beitrags war selbst Mitglied des Teams, das für die Universität Erfurt an der Lernspiel-App gearbeitet hat. Zahlreiche Entscheidungen, die die Lernspiel-App ausmachen, waren das Ergebnis von unzähligen interdisziplinären Diskussionen und Kompromissen, sodass ein gewisser Grad an Befangenheit nicht gänzlich ausgeschlossen werden kann. ${ }^{9}$

\section{Die Lernspiel-App „Sie heißt jetzt Lotte!”}

Das interdisziplinäre Bildungsprojekt „Sie heißt jetzt Lotte!“ wurde den Studierenden des Masterstudienganges Geschichtsdidaktik der Universität Erfurt erstmals im Oktober 2015 vorgestellt. Es handelte sich zu diesem Zeitpunkt noch um eine Kooperation zwischen dem Münchener Produzententeam von MiriquidiFilm und dem Lehrstuhl für Angewandte Informatik der Fachhochschule Erfurt, die gemeinsam auf der Suche nach historischer Beratung und konzeptionell-didaktischer Unterstützung für die Entwicklung einer LernspielApp für den Einsatz im Klassenzimmer waren.

Dabei ging es um eine Lernspiel-App, die auf dem gleichnamigen und bereits fertiggestellten Kurzfilm „Sie heißt jetzt Lotte!“" ${ }^{10}$ basieren sollte. Bei dem Produzententeam war die Idee entstanden, auf dem Film aufbauend eine Lern-

9 An dieser Stelle wird darauf verwiesen, dass sich die fachwissenschaftliche und fachdidaktische Einordnung der Lernspiel-App „Sie heißt jetzt Lotte!“ auf Ergebnisse aus meiner unveröffentlichten Masterarbeit von 2017 bezieht. Vgl. Anna-Rosa Haumann: Edutainment-Apps im Geschichtsunterricht. Eine didaktische Untersuchung am Beispiel der historischen Lernspiel-App „Sie heißt jetzt Lotte!“, unveröffentlichte Masterarbeit, Erfurt 2017.

10 Der Kurzfilm „Sie heißt jetzt Lotte!“ ist als 3D-Produktion erschienen und wird im englischen Titel mit „Call her Lotte!“ übersetzt, Regie: Annekathrin Wetzel, Drehbuch: Annekathrin Wetzel, DE: MiriquidiFilm 2014, Fassung: Internet. http://www.bild.de/unterhaltung/kino/kurz film/sie-heisst-jetzt-lotte-bei-bild-de-38538352.bild.html (letzter Zugriff: 12.09. 2019). 
spiel-App zu konzipieren, die neue Wege in der transmedialen Bildungsarbeit geht. Der Kurzfilm erzählt die fiktive, aber historisch mögliche Geschichte der Freundinnen und Schauspielkolleginnen Lea und Maria, von denen die eine Jüdin und die andere Nichtjüdin ist. Die enge Freundschaft der beiden wird durch die rassistische Ideologie der NS-Diktatur herausgefordert. Lea, die im Laufe des Films immer deutlicher von den Repressionen gegen die jüdische Bevölkerung betroffen ist, verliert ihre Anstellung am Theater, während ihre Freundin Maria den deutschen SS-Offizier Hans heiratet und Leas Hauptrolle im Theater übernimmt. Hans verbietet Maria den Kontakt zu Lea, die mittlerweile von ihrem jüdischen Mann Aaron ein Kind erwartet, woraufhin die Freundinnen beginnen, sich Briefe zu schreiben.

Die beiden Frauen müssen sich somit im zunehmend radikalisierenden NSRegime und dem damit einhergehenden gesellschaftlichen Wandlungsprozess neu positionieren. Als im November 1942 in München die Judendeportationen beginnen, entschließt sich Maria dazu, Lea aufzusuchen, um sie und ihr zweijähriges Kind Charlotte vor der drohenden Deportation zu warnen. Maria fordert ihre Freundin zur Flucht auf, was Lea jedoch ablehnt, da sich die Beamten, die die Deportationen durchführen, bereits in ihrem Hausflur befinden. Lea entschließt sich kurzerhand dazu, ihrer Freundin das Kind mit dem letzten Satz „Sie heißt jetzt Lotte!“ anzuvertrauen, um das Mädchen zu retten. Als Marias Ehemann Hans am Abend nach Hause kommt und Charlotte entdeckt, kommt es zur Eskalation. Hans greift zur Pistole und schießt mehrere Male auf das Kind und seine Frau, die im letzten Augenblick mit dem Kind die Wohnung verlassen kann. ${ }^{11}$

Von dieser Geschichte ausgehend, zielt das Bildungsprojekt darauf ab, eine Lernspiel-App zu entwickeln, um historisches Lernen im Geschichtsunterricht mithilfe von neuen technischen Möglichkeiten so zu gestalten, dass die methodische Umsetzung des herausfordernden Themengebiets Nationalsozialismus mit der digital geprägten Lebenswelt der Schülerinnen und Schüler didaktisch verknüpft wird.

\section{Anfängliche Ideenfindung und interdisziplinäre Kommunikation}

Es galt nun die einzelnen Komponenten wie das historische Arbeiten und die didaktische Umsetzung für den schulischen Kontext mit den zur Verfügung stehenden neuen medialen Möglichkeiten gewinnbringend $\mathrm{zu}$ kombinieren und in einen praktischen Bezug zu setzen. Die ersten Monate der Kooperation

11 Vgl. Annekathrin Wetzel: Sie heißt jetzt Lotte!, Drehbuch, München 2013. Vgl. Sie heißt jetzt Lotte!, Regie: Annekathrin Wetzel, MiriquidiFilm 2014. 
zwischen dem Münchener Produzententeam, der Fachhochschule Erfurt und der Universität Erfurt waren geprägt von sehr unterschiedlichen Kommunikationsweisen, in denen die verschiedenen Mitwirkenden anfangs nur schwer zusammengefunden haben. So war es dem Produzententeam besonders wichtig, dass sich das Spiel nah an der fiktiven Filmvorlage orientiert und sich möglichst schnell zu einem spielbaren Prototyp entwickelt. Die Informatikerinnen und Informatiker hingegen legten ihren Fokus auf die praktische GamingUmsetzung in der Programmierung. Hierzu zählten unter anderem die technische Innovation, die Arbeit mit Augmented Reality ${ }^{12}$, die Einfügung einer 3DPanorama Zone ${ }^{13}$ und die zahlreichen weiteren Tools, die das Lernspiel zu einem digitalen Erlebnis machen sollten.

Das Projektteam des Lehrstuhls für Neuere und Zeitgeschichte und Geschichtsdidaktik wiederum war stets um die Authentizität der Quellenlage besorgt. Aus geschichtswissenschaftlicher Sicht war es ein weitreichender Diskussionspunkt, dass es sich bei den Filmcharakteren, die auch die Grundlage des Spiels bilden sollten, um fiktive Personen handelt. Für Historikerinnen und Historiker stellt es einen essenziellen Unterschied dar, ob die zugrunde liegende Kontextualisierung real oder fiktiv ist. Wie ist es auf dieser Grundlage überhaupt möglich, eine historische Quellenlage zu konstruieren und in welcher Art und Weise müssen die recherchierten Quellen so abgeändert werden, dass sie in die zu erzählende Geschichte in der Lernspiel-App eingebettet werden können? Ist es legitim, selbst fiktionale Geschichten zu konstruieren oder sollte der Vorgang der Rekonstruktion stets auf der Grundlage historischen Quellenmaterials erfolgen? Wie wird dafür Sorge getragen, dass die Schülerinnen und Schüler nach dem Spiel nicht die Realität mit der Fiktion verwechseln? Es ging für die beteiligten Studierenden der Universität Erfurt um grundsätzliche Fragen des historischen Arbeitens sowie um das Problem, wie viel wissenschaftliche Relevanz notwendig sei, um das Spiel als historisches Lernspiel in der Schule zu integrieren und damit auch auf fachlicher Ebene zu legitimieren.

Als besonders brisant zeigten sich die unterschiedlichen Fachkulturen und die damit verbundenen Fachtermini. So gab es zu Beginn wenig Konsens darüber, was mit bestimmten Begriffen im Einzelnen gemeint war. Die Historikerinnen und Historiker mussten erfassen, was beispielsweise unter Augmented Reality zu verstehen war, wie sogenannte Beacons und QR-Codes eingesetzt werden oder wie sich eine Portalzone zur Betrachtung von 360-GradPanoramen realisieren lässt. Darüber hinaus standen sie vor der Herausforde-

12 Eine computergestützte Erweiterung der Realität mittels visueller Einblendung oder Überlagerung auf einem digitalen Endgerät.

13 Ein durch Beacons eingegrenzter Bereich, in dem sich durch aktives Bewegen eines Endgerätes 360-Grad-Panoramabilder realisieren lassen. 
rung, sich nicht nur auf einzelne Begriffe, sondern auch auf eine andere Perspektive einzulassen. So mussten die zusammengetragenen Ideen nicht nur ausformuliert oder historisch korrekt eingebettet, sondern auch so durchdacht werden, dass sie sowohl potenziell in einem digitalen Lernspiel umgesetzt werden können als auch einen spielerischen und auffordernden Charakter innehaben.

Ein Kritikpunkt aus Sicht des Informatiker- und Produzententeams war daher immer wieder das zu diesem Zeitpunkt noch zu einseitige Game-Design, das dem Spiel seinen eigentlichen motivationalen Charakter durch einen zu verschulten Blickwinkel auf den Lerngegenstand entziehen könnte. An dieser Stelle wäre zumindest ein grundlegendes Verständnis über das Prinzip der Programmierung bei den Historikerinnen und Historikern von großem Nutzen gewesen.

Hingegen war dem Informatiker- und Produzententeam weder die Reichweite des Quellenbegriffs noch die der Quellengattungen bewusst. So wurde der Begriff Quelle für alle Arten von Darstellungen genutzt, ganz gleich ob es sich hierbei um Primärquelle oder Sekundärliteratur handelte. Auch führte das Verständnis von Multiperspektivität und Kontroversität zu Missverständnissen. Die Tatsache, dass Quellen perspektivisch sind und die Vergangenheit aus bestimmten religiösen, kulturellen, politischen oder nationalen Blickwinkeln darlegen, stellte genauso wenig eine Selbstverständlichkeit dar, wie die Gegebenheit, dass die Geschichte immer auch ein Konstrukt, also ein Ergebnis der Deutung einer Historikerin oder eines Historikers ist. ${ }^{14}$

Dass sich das Projekt in eine positive und auch konstruktive Richtung entwickeln konnte, war das Ergebnis von vielen Gesprächen, zahlreichen Skypeterminen, von viel Verständnis für die gegenseitigen Interessen und einer auf allen Seiten hohen intrinsischen Motivation dem eigentlichen Projektziel gegenüber. Hätten nicht alle Beteiligten einen derart hohen didaktischen und innovativen Mehrwert in dem Konzept und der digitalen Herangehensweise der Lernspiel-App gesehen, wäre das Spiel sicher nicht über diverse Durststrecken hindurchgekommen.

14 Vgl. Klaus Bergmann: Multiperspektivität, in: Ulrich Mayer, Hans-Jürgen Pandel, Gerhard Schneider (Hrsg.): Handbuch. Methoden im Geschichtsunterricht, 4. Auflage, Schwalbach/Ts. 2013, S. 65-77, hier S. 65-66. 


\section{Erste Fortschritte im Spielablauf}

Im Herbst 2016, also ein Jahr nach Projektbeginn, befand sich die LernspielApp „Sie heißt jetzt Lotte!“ auf einem guten Weg. Es gab ein strukturiertes Entwicklungskonzept, die Tools wurden programmiert und die ersten Aufgaben (Quests) wurden mit historischen Inhalten aus dem Münchener Stadt-, Staats- und Hauptstaatsarchiv gefüllt.

Festgelegt wurde bis zu diesem Zeitpunkt, dass die interaktive und mobile Lernspiel-App für den Einsatz im Klassenzimmer gedacht sein und sich an 14bis 18-jährige Schülerinnen und Schüler der 9. und 10. Klassen richten soll, die jeweils in Kleingruppen spielen. Grundsätzlich soll der Spielablauf nicht an die Größe einer Klasse gebunden sein und aufgrund von geteilten Gruppen unabhängig von der Anzahl der Lernenden spielbar werden.

Positiv stellt sich dar, dass keine besondere technische Ausstattung in der jeweiligen Schule benötigt wird, um das Spiel mit einer Klasse spielen zu können. Alle relevanten und notwendigen Komponenten, wie die Tablets, Buttons zum Einrichten der Panoramazone, die Stadtkarte und das benötigte Unterrichtsmaterial befinden sich in einem transportablen Koffer, der bestellt und ausgeliehen werden kann. Es ist weder ein eigener Klassensatz Tablets noch eine kniffelige Installation auf den Geräten nötig, was zu einem unkomplizierten Umgang und Einsatz führen soll. Das Spiel ist somit für alle Schulen potenziell spielbar, unabhängig vom jeweiligen technischen Ausrüstungsstand der Institution.

Eine Kleingruppe besteht aus sechs Personen, die sich jeweils in drei Zweiergruppen aufteilen, sodass jeweils in Tandems gespielt wird. Der Gruppentisch, bestehend aus diesen drei Tandems, stellt die Base dar, in der immer wieder die Einzelergebnisse mit der Gruppe abgeglichen werden müssen. Darüber hinaus werden im Klassenzimmer weitere Bereiche installiert. So gibt es eine Archivzone, in der Materialien (Dokumente, Artefakte, Bildmaterial und die Stadtkarte von München) zur Verfügung stehen und eine Portal- bzw. Panoramazone, die die Betrachtung von 360-Grad-Panoramen ermöglichen soll. Die Lehrperson kann die Spielprozesse über die Zentrale steuern und kontrollieren und agiert als Administrator mittels eines übergeordneten Tablets (siehe Abbildung 1). 


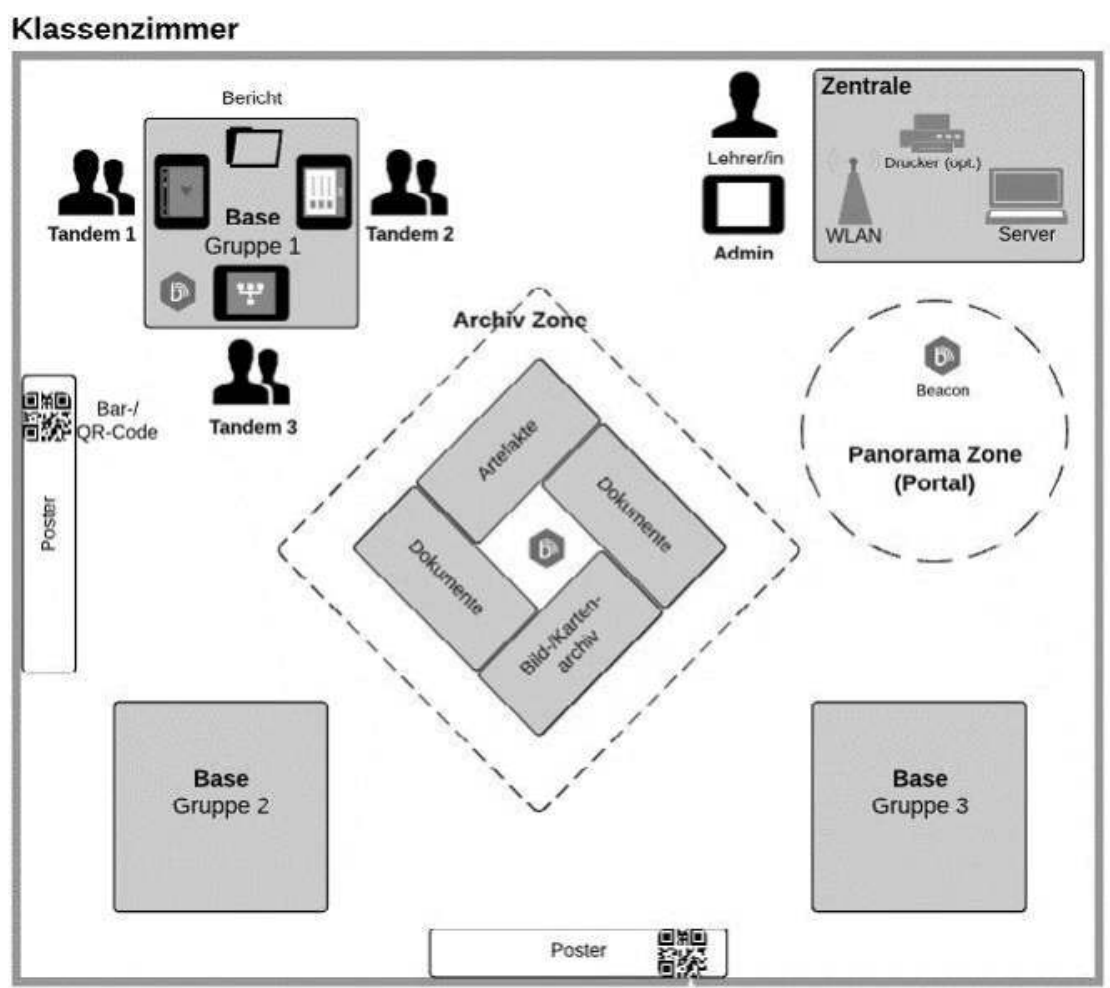

Abbildung 1: Spielaufbau im Klassenzimmer, Konzeptskizze, Rolf Kruse, Februar 2016.

Die Aufgabe des Spiels ist im Wesentlichen, die im Film verhandelten Familienverhältnisse zu klären. Die jeweiligen Tandems sind im Vorfeld einem der drei Hauptcharaktere zugeordnet und müssen jeweils einen Steckbrief zu dieser Person ausfüllen. Dies geschieht, indem die Schülerinnen und Schüler in die Rollen von Detektivinnen und Detektiven schlüpfen, um die damaligen historischen und beziehungsrelevanten Geschehnisse zu rekonstruieren.

$\mathrm{Zu}$ Beginn des Spiels bekommen alle Tandems eine digitale Spieleinführung mittels eines Intros, um sich in die Ausgangssituation hineinbegeben zu können. Es wird erklärt, dass es sich um den ungelösten Fall der Akte Lotte handele, die es zu durchdringen gilt, um einen noch ausstehenden Erbfall zu lösen. Der zuständige Agent Stern habe bereits begonnen einige Informationen zusammenzutragen, benötige aber die Hilfe von den Detektivinnen und Detektiven (siehe Abbildung 2). 
76

Anna-Rosa Haumann

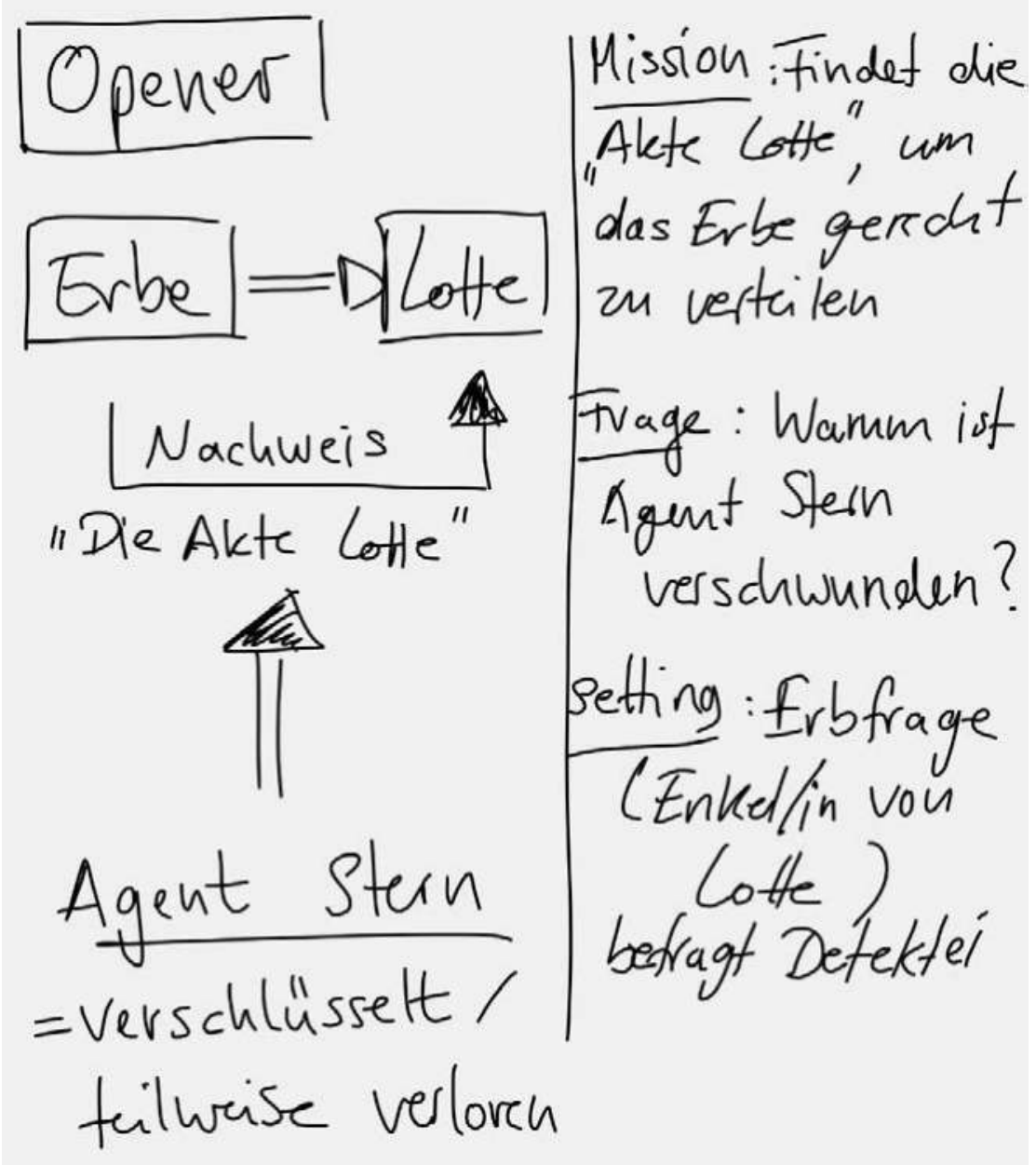

Abbildung 2: Erster gemeinsamer Entwurf, Januar 2016.

Die Schülerinnen und Schüler werden dazu aufgefordert, ihm beim Lösen dieses Falls zu helfen und jeweils zu zweit einen der drei Personenstränge genauer zu untersuchen. Alle Hinweise, die im Laufe des Spiels über die gestellten Aufgaben (Quests) gefunden und gesammelt werden, müssen in die vorgegebene Benutzeroberfläche des zugeordneten Tablets eingepflegt werden, sodass am Ende ein vollständiges Personenprofil sichtbar wird. Auf der linken Seite der Benutzeroberfläche ist eine abgebildete Zeitleiste zu sehen, die sich synchron $\mathrm{zu}$ den gefundenen Informationen ergänzt und einen schnellen

Open-Access-Publikation im Sinne der CC-Lizenz BY-SA 4.0

(c) 2020, Vandenhoeck \& Ruprecht GmbH \& Co. KG, Göttingen

ISBN Print: 9783847111771 - ISBN E-Lib: 9783737011778 
Überblick über die chronologische Abfolge der historischen Ereignisse ermöglicht (siehe Abbildung 3).

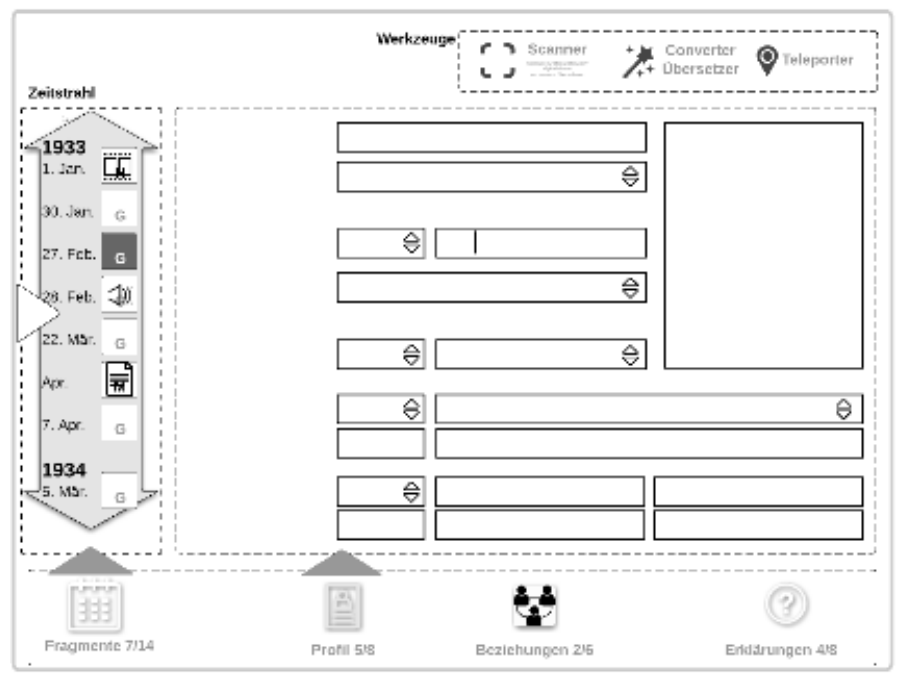

Abbildung 3: Erster Entwurf der Benutzeroberfläche, Rolf Kruse, August 2016.

Mit dem Kartenwerkzeug können digitale Inhalte lagerichtig über eine reale Karte überblendet werden. Dazu erkennt das Tablet mit seiner Kamera vorher erfasste optische Merkmale der Karte und berechnet daraus seine eigene relative Position. Mit dieser Information können dann digitale Inhalte wie Textinformationen, Bilder, Videos oder 3-D-Modelle so in das Kamerabild eingeblendet werden, dass es für den Spielenden wirkt, als wären diese real auf der Karte vorhanden (siehe Abbildung 4).

Im Laufe des Spiels ist der stetige Informationsaustausch in der Kleingruppe von hoher Relevanz, um die übergeordnete Frage zu klären, wessen Kind die zweijährige Lotte ist und wer demnach als erbberechtigte Person infrage kommt. So ergibt sich, dass es zu keinem direkten Konkurrenzkampf kommt, sondern dass die Gruppe mit unterschiedlichen Schwerpunkten arbeitet. Am Ende einer Spieleinheit werden die Informationen an der Base verglichen und die Gruppe bekommt einen Ergebnisbogen ausgehändigt, der die benötigte Zeit, die verbrauchten Hinweise, die gefundenen Fragmente und die Vollständigkeit der Profile beinhaltet. Das Ziel des Spiels ist erreicht, wenn die Gruppe den Fall die Akte Lotte erfolgreich gelöst hat und das Kind der eigentlichen Mutter zugeordnet hat (siehe Abbildung 5). 

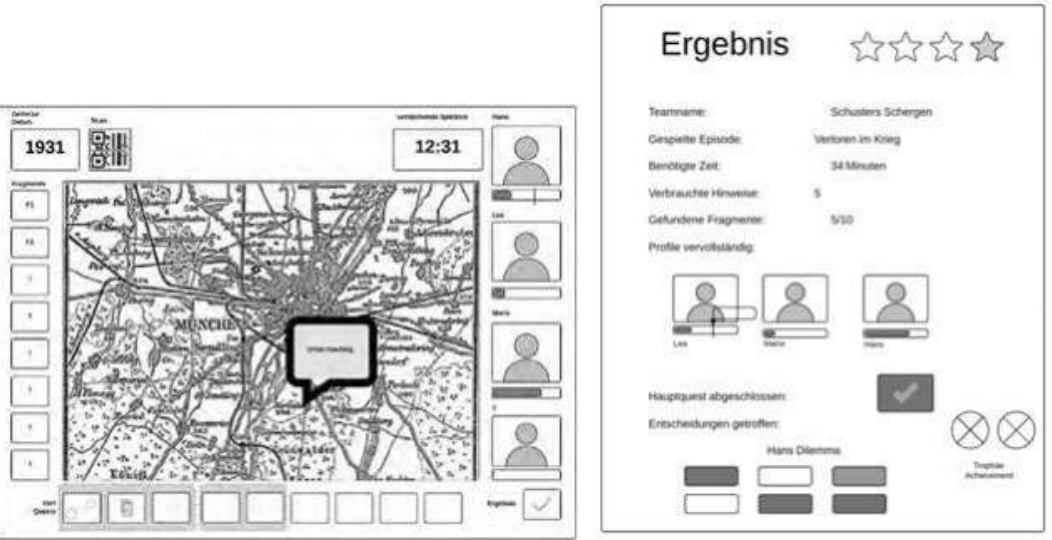

Abbildung 4-5: Erster Entwurf des Kartenwerkzeuges, Rolf Kruse, August 2016; Auswertungsbogen, Konzeptskizze, Rolf Kruse, März 2016.

\section{Aktueller Projektstand und weitere Planungen}

Das oben skizzierte Konzept stand bei den folgenden Arbeiten immer wieder zur Diskussion. Was muss programmiert werden? Wie schlüssig stellt sich das Storytelling dar? Welche Tools müssen ins Spiel integriert werden und wie weit ist man noch von einer spielbaren Beta-Version entfernt?

Eine erste grundlegende Änderung findet sich in der Tatsache, dass es sich bei der Leitung der Detektei nicht mehr um den Agenten, sondern um die Agentin Stern handelt. Gängige Rollenmuster von einem männlichen Agenten, der mit Pfeife und Hut in einem verrauchten und dunklen Büro sitzt, sollten abgelöst und durchbrochen werden. Eine junge, moderne Agentin tritt stattdessen an seine Stelle, führt die neuen Detektivinnen und Detektive durch die ersten Spielminuten und gibt mithilfe des Intros eine Einführung in die relevanten Tools und Aufgabenformate. Es wird erklärt, dass es sich um einen ungelösten Fall des fiktiven Ermittlungsbüros History Detectives Special Investigations handelt und die zuständige Agentin Stern bereits begonnen hat, einige Informationen zusammenzutragen, jedoch die Hilfe von den Detektivinnen und Detektive benötigt. Die Schülerinnen und Schüler werden dazu aufgefordert, dem Ermittlungsbüro beim Lösen dieses Falls zu helfen.

$\mathrm{Zu}$ Beginn des Intros werden kleinere Aufgaben an die jeweiligen Tandems gestellt, die sie bei erfolgreicher Absolvierung dafür qualifizieren sollen, Teil des Detektivbüros zu werden. Nach der Eingabe eines Gruppennamens und eines selbst gewählten Passwortes werden die Spielenden mit einer Videosequenz konfrontiert, in der sie aus mehreren Fotos das jeweils richtige Steck- 
briefbild für ihre zu recherchierende Person identifizieren müssen. Nach erfolgreich absolvierter Aufgabe wird das Kartentool mittels Intro eingeführt, indem die Spielenden nun eine Adresse in ihrem Steckbrief aufrufen können. Mit dem Kartentool können digitale Inhalte wie Textinformationen, Bilder, Videos und 3-D-Modelle lagerichtig über eine analoge Karte aus dem Jahr 1938 überblendet werden, indem das Tablet vorher erfasste optische Merkmale (Features) der Karte erkennt und daraus seine eigene Positionierung relativ zur Karte berechnet. Ein weiteres feststehendes Tool ist der in der Profilansicht integrierte und dauerhaft sichtbare Zeitstrahl, welcher zum einen der chronologisch-historischen Übersicht sowie zum anderen als Speicherplatz für die im Spielverlauf gesammelten Fragmente (Informationen) dient. Die Anzeige der einzelnen Elemente kann horizontal verschoben werden, sodass die jeweiligen Fragmente (Quellen) im Detailbereich angezeigt und dort bearbeitet werden können.

Das neu konzipierte Converter-Modul - auch Decoder oder Übersetzer genannt - erlaubt, eingesammelte, aber nicht lesbare Fragmente umzuwandeln. So können die Schülerinnen und Schüler beispielsweise die Übersetzung eines Briefes, der in Sütterlin geschrieben ist, in eine heute übliche Schreibschrift umwandeln, um die Quelle inhaltlich auswerten zu können.

Die Detektivinnen und Detektive gelangen nun mittels der Karte zu einer Wohnungstür, die noch mit einem Code verschlossen ist. Die Lösung ist an neun unterschiedlichen historischen Orten im Raum München versteckt, die die Schülerinnen und Schüler im Folgenden mittels kleiner Rätsel im SingleChoice-Stil sammeln müssen. Jedes Tandem recherchiert drei für ihre Person relevante Orte, die dann in der Gruppe zusammengetragen werden. Die korrekten Antworten ergeben Teile des Lösungscodes, mit der die Tür zur Wohnung von Hans und Maria nun gemeinsam geöffnet werden kann. Hier endet das Intro und das eigentliche Detektivspiel beginnt, indem die Schülerinnen und Schüler nun selbstständig mit den unterschiedlichen Tools agieren und die relevanten Quellenfragmente einsammeln und auswerten können.

Es zeigt sich, dass nach Auslaufen der aktiven Projektphase viel passiert ist und eine spielbare Demoversion nun theoretisch implementiert werden kann. Die Rahmenhandlung ist konstruiert, die einzelnen Tools sind in die Benutzeroberfläche integriert und könnten nun von den Lernenden interaktiv genutzt werden. 


\section{Konzeptionelle Einordnung der Lernspiel-App}

Um eine fachdidaktische Einordnung zum Einsatz der Lernspiel-App im Unterricht zu schaffen, mussten anschließend an die vorangehenden Ausführungen weitere Überlegungen hinsichtlich der Ziele bei der Vermittlung der Geschichte des Nationalsozialismus formuliert werden. Ziel sollte es am Ende der Unterrichtseinheit sein, dass sich bei den Schülerinnen und Schülern ein thematisch differenziertes Geschichtsbewusstsein feststellen lässt, welches nicht bloß die Differenzierung zwischen Täter, Opfer und Zuschauer ${ }^{15}$ zulässt, sondern die gesamte Gesellschaftsstruktur unter kritischer Reflektion des ,NSVolksgemeinschaftskonzepts' in den Blick nimmt und inkludierende und exkludierende Vergemeinschaftungsprozesse im Nationalsozialismus betrachtet.

Auf Basis dieses Entwicklungsprozesses wird in einem weiteren Schritt versucht, die dem Projektteam vorliegenden Ergebnisse in einen kritischen und wissenschaftlichen Kontext einzugliedern, indem die Lernspiel-App „Sie heißt jetzt Lotte!" aus medienkritischer, fachwissenschaftlicher und didaktischer Sicht in den Schulunterricht verortet wird.

\subsection{Medienkritische Einordnung}

Aus medienkritischer Sicht stellen sich die Fragen, wie Computer, Tablets und Smartphones generell als Lehr- und Lernmittel eingesetzt werden können, welche Möglichkeiten und Ziele sich daraus ergeben und was diese Medien im Einzelnen charakterisiert. Unter Berücksichtigung von Serious Games, die alle als nicht primär der Unterhaltung dienende Spiele zu verstehen sind, ${ }^{16}$ muss eine Verortung des Einsatzes von Spielen im Geschichtsunterricht vorgenommen werden, um die Möglichkeiten und Probleme beim Spielen im schulischen Kontext zu beleuchten. Sodann müssen die zuvor diskutierten Resultate konkret auf die zu untersuchende Lernspiel-App „Sie heißt jetzt Lotte!“ bezogen und erörtert werden. Es wird die Frage aufgeworfen, inwiefern die Lern-

15 Vgl. Raul Hilberg: Täter, Opfer, Zuschauer. Die Vernichtung der Juden 1933-1945, 5. Auflage, Frankfurt am Main 1992.

16 Vgl. Michael Wagner: Serious Games: Spielerische Lernumgebungen und deren Design, in: Paul Klimsa, Ludwig J. Issing (Hrsg.): Online Lernen. Handbuch für Wissenschaft und Praxis, 2. Auflage, München 2011, S. 297-305, hier S. 298. Anzumerken ist, dass der Begriff Serious Games nach wie vor kritisch betrachtet werden muss, da es bisher keine tatsächlich wissenschaftlich haltbaren Kriterien gibt, um die Ernsthaftigkeit von Spielen schlüssig zu definieren oder zu messen. Gemessen an dieser Aussage müsste davon ausgegangen werden, dass Spiele, mit denen Kinder ihre Umgebung entdecken, unter objektiven Bedingungen keinen ernsthaften Charakter haben, sodass der Begriff der Ernsthaftigkeit nur ein geringes Maß an Erkenntniszugewinn aufweist. 
spiel-App durch die gewählte Methodik des Serious Gaming eine für den Geschichtsunterricht bereichernde Rolle spielen kann, indem erstens nach den motivationalen Komponenten und zweitens nach der methodischen Abwechslung gefragt wird.

Um die gewünschte Aufmerksamkeit bei den Lernenden zu erzielen, bedarf es im schulischen Kontext häufig mehr als die bloße Konfrontation mit einem Sachgegenstand. Es zeigt sich, dass die Höhe der Motivation eine grundlegende Voraussetzung für erfolgreiches Lernen ist, die eng an die persönlichen Interessen und die kognitiven Voraussetzungen der Lernenden geknüpft ist. Empfindet ein Lernender ein Thema als interessant, eröffnet sich ihm daraus ein Vorteil für seine Aufmerksamkeitssteuerung, sodass sich sein kognitives System auf einem optimalen Funktionsniveau befindet. ${ }^{17}$

Das geplante Game-Konzept hat daher grundsätzlich die Aufgabe, die Schülerinnen und Schüler durch einen motivierenden Charakter dahin gehend zu begeistern, dass diese gewillt sind, sich auf das Spiel einzulassen. Um dies zu generieren wurden historisch relevante Inhalte in einen der Altersgruppe nahestehenden inhaltlichen Kontext gebracht. Die Schülerinnen und Schüler sollen die gemeinschaftlichen Verflechtungen (die Freundschaft zwischen Maria und Lea und die Beziehung zwischen Hans und Maria) der Protagonisten rekonstruieren, um die Reichweite der historischen Ereignisse im Kontext des Nationalsozialismus deuten zu können.

Mithilfe des Gaming-Charakters wird ein weiterer motivationaler Aspekt bedient, da es eine Grundeigenschaft des Spielens darstellt, die Aufgaben möglichst mit Erfolg meistern zu wollen, um so selbstwirksam tätig zu werden. Da die Lernspiel-App „Sie heißt jetzt Lotte!“ jedoch nicht darauf ausgelegt ist, dass jeder Spielende für sich alleine spielt, sondern dass es ein gemeinsam zu erreichendes Gruppenergebnis gibt, werden soziale Motivationscluster wie ,Kontakt $\mathrm{zu}$ anderen Mitspielenden pflegen' und deren ,Zuwendung und Wertschätzung erfahren' zusätzlich bedient. Durch die Einteilung in Kleingruppen wird der sozialen Kompetenz eine hohe Signifikanz zugeschrieben. Die Gruppe erreicht zusammen, in einem wiederkehrenden Rhythmus des Informationsaustausches, das übergeordnete Ziel, den Erbschaftsfall der Akte Lotte zu klären. Alle drei Tandems bearbeiten und lösen innerhalb ihrer Gruppe die ihnen gestellten Aufgaben und erfahren für ihren Bereich den eigenen Wissensvorsprung der erforschten Person, während die ganze Gruppe auf die Ergebnisse aller drei Tandems angewiesen ist und nur gemeinsam zum Ziel gelangen kann. ${ }^{18}$

17 Vgl. Marcus Hasselhorn, Andreas Gold: Pädagogische Psychologie. Erfolgreiches Lernen und Lehren, 3. Auflage, Stuttgart 2013, S. 109-110.

18 Vgl. Martin Lorber, Thomas Schutz: Gaming für Studium und Beruf. Warum wir lernen, wenn wir spielen, Berlin 2016, S. 27. 
Eine weitere methodische Vielfalt ergibt sich aus den zahlreichen unterschiedlichen Materialien, die mithilfe dieser Lernspiel-App verwendet werden. Die erste zu bearbeitende Aufgabe ist eine Fotozuordnung für das zu erstellende Profil, sodass die Schülerinnen und Schüler explizit nach ausweisähnlichen Dokumenten (Reisepass/Wehrpass) suchen müssen. Eine weitere relevante Quelle stellt der Völkische Beobachter ${ }^{19}$ dar. Die Münchener Tageszeitung, die als Parteiorgan der NSDAP fungierte und seit 1925 zur Verbreitung der NSIdeologie beitrug, ${ }^{20}$ wird als historische Primärquelle herangezogen, die es kritisch zu untersuchen gilt. Neben diesen hier vorgestellten Aufgabenfeldern zeigen sich im Laufe des Spiels zahlreiche weitere zu lösende Rätsel und Probleme. Das Spiel verfügt über einen großen Fundus an analogen und digitalen Materialien. So kann zum einen durch den Einsatz von Tablets im Unterricht der spielerische Charakter und die methodische Abwechslung und zum anderen die breit gefächerte Quellen- und Materialauswahl eine Bereicherung für den Geschichtsunterricht und das historische Lernen bieten. ${ }^{21}$

\subsection{Fachwissenschaftliche Einordnung}

Besonders wichtig ist es an dieser Stelle, die Lernspiel-App „Sie heißt jetzt Lotte!" auch aus dem geschichtswissenschaftlichen Blickwinkel zu besprechen, um neben der didaktischen Komponente eine fundierte historische Einordnung erreichen zu können und somit die Fachdidaktik eng an die historische Forschung anzulehnen. Es wird daher untersucht, wie die soziale Praxis im ,Dritten Reich' mithilfe des, in der Lernspiel-App thematisierten, Konzepts der ,Volksgemeinschaft' verhandelt werden soll.

Die nationalsozialistische, Volksgemeinschaft' verstand sich primär als eine Art Abstammungsgemeinschaft, da die Rassenzugehörigkeit aufgrund der biologischen Herkunft und bestimmter körperlicher Merkmale zum entscheidenden beziehungsstiftenden und strukturierenden Faktor der Sozialordnung wurde. Hier verbanden sich unterschiedliche Traditionsstränge biologischdarwinistischen Denkens zu einem rassistischen Gesellschaftsmodell, welches

19 Vgl. Völkischer Beobachter vom 28. Februar 1933 aus Anlage 9. 2, aus: Stadtarchiv München, Völkischer Beobachter vom 28. Februar 1933, 1.

20 Vgl. Paul Hoser: Völkischer Beobachter, in: Historisches Lexikon Bayerns. https://www. historisches-lexikon-bayerns.de/Lexikon/Völkischer_Beobachter (letzter Zugriff: 03.09.2019).

21 An dieser Stelle muss angemerkt werden, dass es keine konkrete Evidenz darüber gibt, wie hoch der Mehrwert der hier vorgestellten Lernspiel-App „Sie heißt jetzt Lotte!“ tatsächlich ausfällt. Anhand der vorgeschlagenen Kriterien von Motivation, methodischer Abwechslung und der Herstellung bzw. Förderung des Geschichtsbewusstseins können daher nur Wahrscheinlichkeiten und Erfahrungswerte dargestellt werden. 
für sich eine wissenschaftliche Exklusivität beanspruchte. Die Aussonderung alles ,Andersartigen“ und Nicht-Konformen wurde zum Konzept, welches durch eine Beeinflussung von Erbanlagen darauf abzielte, die Eigenschaften eines Volkes grundlegend zu verbessern. ${ }^{22}$

Der Begriff der, Volksgemeinschaft' bildete daher nicht nur den Leitbegriff der NS-Propaganda, sondern konstruierte auch eine vor allem auf Exklusionsmechanismen basierende Politik. Zugleich war die nationalsozialistische Ideologie im Kern mit den Begriffen ,Volksgenosse vs. Gemeinschaftsfremder verbunden, die das angestrebte Gemeinschaftsmodell beschreiben, welches aufgrund von rassischen, sozialbiologischen oder politischen Gründen eine Exklusion und Separation von ,Volksschädlingen' vornahm. So ist festzustellen, dass der Begriff und das Konzept der, Volksgemeinschaft' durch die Nationalsozialisten als eine zugespitzte ideologische Fortentwicklung und Radikalisierung der nationalkonservativen Gemeinschaftsidee zu verstehen ist.

In Bezug auf den Geschichtsunterricht gilt es daher auch, nicht mehr ausschließlich nach „Widerstand und Resistenz“ zu suchen oder in der Trias „Täter - Opfer - Zuschauer" ein in allen Einzelheiten differenziertes Schema für die Erklärung sozialen Verhaltens zu begreifen. Eine simplifizierende Darstellung des Täters in der Rolle von Hans, des jüdischen Opfers Lea und der Zuschauerin Maria, die in dieser Rolle nur wenig oder gar keinen Handlungsspielraum zugesprochen bekäme, hätte hier nicht die Reichweite die gesellschaftsrelevanten und sozialen Verflechtungen abzubilden. Es geht darum, durch eine Auseinandersetzung mit der Thematik ein Verständnis über die Gemeinschaftsvorstellungen zu entwickeln und zu verstehen, wie diese in die nationalsozialistischen Strukturen eingebettet wurden. ${ }^{23}$

Da sich die inhaltliche Komponente der App in weiten Teilen auf den daran angelehnten Kurzfilm bezieht, ergeben sich daher drei aufeinander aufbauende Fragen, die für den Versuch stehen, Geschichte multiperspektivisch und mehrdimensional zu betrachten: 1. Wie konnte es dazu kommen, dass sich eine Gesellschaft derart zügig transformierte, indem sie bewusst neue soziale und politische Räume konstruiert hat? 2. Inwiefern waren die neu geschaffenen Exklusionsmechanismen der ,Volksgemeinschaftsidee' beziehungsstiftend oder beziehungszerstörend, sodass die Weiterführung zuvor bestehender sozialer Beziehungen für bestimmte Personen unmöglich wur-

22 Vgl. Dietmar Süß, Winfried Süß: „Volksgemeinschaft“ und Vernichtungskrieg. Gesellschaft im nationalsozialistischen Deutschland, in: Dies. (Hrsg.): Das „Dritte Reich“. Eine Einführung, München 2008, S. 79-119, hier S. 81-82.

23 Vgl. Michael Wildt: „Volksgemeinschaft“. Eine Antwort auf Ian Kershaw, in: Zeithistorische Forschungen/ Studies in Contemporary History, Online-Ausgabe 8 (2011) 1, S. 102-109. http://www.zeithistorische-forschungen.de/1-2011/id=4756 (letzter Zugriff: 12.09.2019). 
de? 3. Wie wirkte sich die Umsetzung der Exklusionsmechanismen auf die alltägliche Praxis im Einzelnen aus?

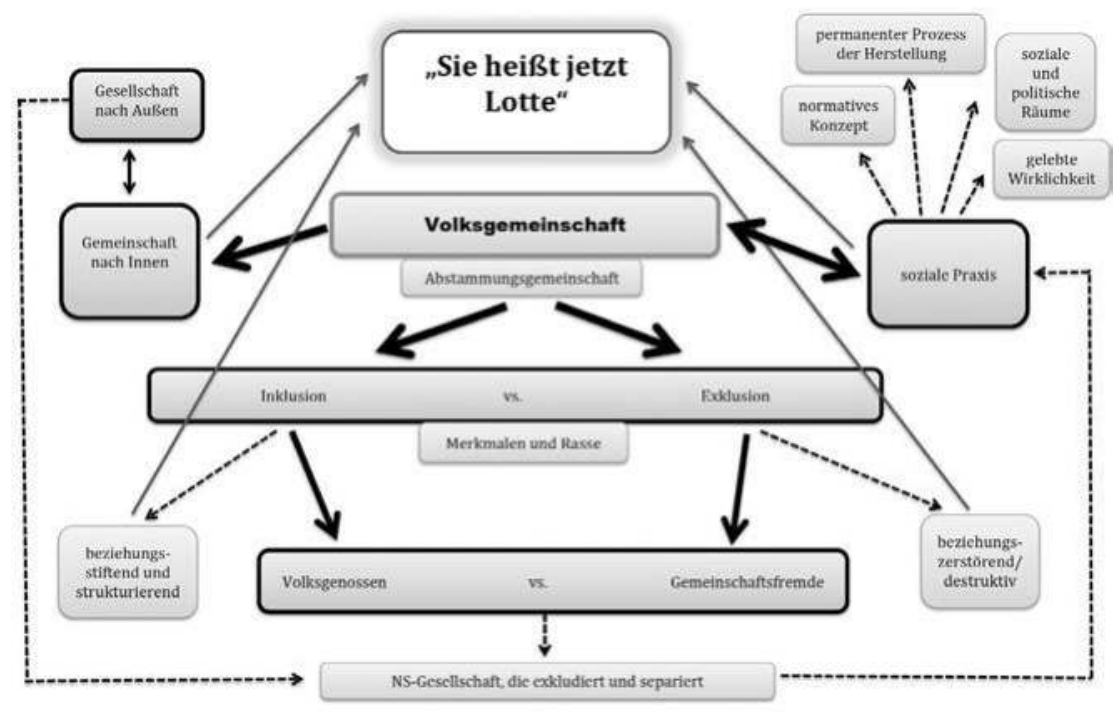

Abbildung 6: Das Gemeinschaftsmodell der ,Volksgemeinschaft', eigene Darstellung, Dezember 2016.

Grundsätzlich wird in erster Linie Bezug auf die Ausführungen von Michael Wildt genommen, der die ,Volksgemeinschaft ${ }^{\text {' }}$ praxeologisch versteht, ${ }^{24}$ und die sich durch normative Konzepte, die gelebte Wirklichkeit und den permanenten Prozess der Herstellung sozialer und politischer Räume immer wieder neu konstruiert. ${ }^{25}$ Aus nationalsozialistischer Perspektive war die ,Volksgemeinschaft immer auch eine Abstammungsgemeinschaft, die aufzeigt, inwiefern die Menschen im damaligen NS-Regime über fest definierte Merkmale und rassespezifische Kriterien durch den Prozess der Inklusion zu sogenannten Volksgenossen integriert bzw. durch die vorgenommene Exklusion zu der Gruppe der Gemeinschaftsfremden exkludiert und separiert wurden. ${ }^{26}$ Die sich ergebenden dynamischen Prozesse wirkten daher entweder beziehungsstiftend

24 Vgl. Wildt: „Volksgemeinschaft“, S. 106-107.

25 Vgl. Alexa Stiller: Sammelrezension: Fiktion und Realität der „Volksgemeinschaft“, in: H-SozKult (18.07.2013), S. 1-4. http://www.hsozkult.de/publicationreview/id/rezbuecher-17158 (letzter Zugriff: 11.09.2019).

26 Vgl. Detlef Schmiechen-Ackerman: „Volksgemeinschaft“: Mythos der NS-Propaganda, wirkungsmächtige soziale Verheißung oder soziale Realitäten im „Dritten Reich“? Einführung, in: Ders. (Hrsg.): „Volksgemeinschaft“: Mythos der NS-Propaganda, wirkungsmächtige soziale Verheißung oder soziale Realitäten im „Dritten Reich“?, Paderborn 2012, S. 13-53, hier S. 4546. 
und damit strukturierend oder beziehungszerstörend und damit destruktiv auf soziale Beziehungen. Der im Zentrum der Abbildung stehende Kasten „Sie heißt jetzt Lotte!" gliedert sich in das Gemeinschaftsmodell ein, indem anhand der angeführten drei Leitfragen untersucht wird, wie sich mithilfe der Lernspiel-App ein Bezug zum vermittelnden inhaltlichen Konzept herstellen lässt. Das zentrale Thema der Lernspiel-App spiegelt sich in den sozialen Beziehungen der drei Charaktere Hans, Maria und Lea wider und zeigt auf, wie diese innerhalb des gesellschaftlichen Wandlungsprozesses im aufsteigenden nationalsozialistischen System neu verhandelt werden (siehe Abbildung 6).

\subsection{Fachdidaktische Einordnung}

Die Konzeption der Lernspiel-App folgt in erster Linie der in der Geschichtsdidaktik bereits etablierten Methodik des „Forschend-entdeckenden Lernens" ${ }^{27}$. Bezogen auf den schulischen Kontext folgt das Forschendentdeckende Lernen dem aufklärerischen Prinzip Sapere aude, welches die Schülerinnen und Schüler zum autonomen und verantwortungsbewussten Handeln befähigen soll. Die Lernenden sollen in einer individualisierten und pluralistisch geprägten Welt nicht nur mit bloßem Wissen, sondern vor allem mit Kompetenzen ausgestattet werden. Diese sollen sie dazu befähigen, neben der Reproduktion von Gelerntem, geistige Fähigkeit zu erwerben, um wissenschaftliches Denken als einen Fortschritt ihres eigenen Denkens zu verstehen. ${ }^{28}$ Des Weiteren lässt sich die App den kognitiv-konstruktivistischen Lehr-LernTheorien zuordnen, die mit einer vergleichsweise geringen Ausprägung von äußeren Anleitungs- und Steuerungskomponenten ausgestattet sind. ${ }^{29}$ Sie wird als eine komplexe Form des selbstständigen Lernens verstanden, bei dem die Lernenden zu einem bestimmten Phänomen Problemlösungen suchen, um neue Erkenntnisse zu gewinnen. Bereits generiertes Wissen wird in diesen Prozessen miteinbezogen und regt die Schülerinnen und Schüler zum kritischen Nachdenken an, wovon man sich ein höheres Maß an intrinsischer Motivation verspricht. Es wird davon ausgegangen, dass sich die Lernenden das Wissen und die Fähigkeiten einsichtsvoller und nachhaltiger aneignen können, wenn sie den Weg zu diesem Wissen durch Neugier und Interesse selber gefunden haben. ${ }^{30}$

27 Hasselhorn, Gold: Pädagogische Psychologie, S. 289-290.

28 Vgl. Gerhard Henke-Bockschatz: Forschend-entdeckendes Lernen, in: Ulrich Mayer, HansJürgen Pandel, Gerhard Schneider (Hrsg.): Handbuch. Methoden im Geschichtsunterricht,

4. Auflage, Schwalbach/Ts. 2013, S. 15-29, hier S. 16-17.

29 Vgl. Hasselhorn, Gold: Pädagogische Psychologie, S. 287.

30 Vgl. Henke-Bockschatz: Forschend-entdeckendes Lernen, S. 15. 
Die Personalisierung von Geschichte anhand der Protagonisten Hans, Maria und Lea ist zwar nicht völlig unkritisch zu beurteilen und vermag auch problematische Eigenschaften wie den Verlust an Komplexität und die Einengung von Multiperspektivität in Bezug auf die Vermittlung von historisch relevanten Vorgängen tragen. Sie ist jedoch dazu in der Lage, die Sicht einer bestimmten Personengruppe auf die Alltagswelt mit ihren durchschlagenden und epochenprägenden Strukturen und Prozessen darzustellen. ${ }^{31}$ Der individualisierte Zugang zur Geschichte erzeugt somit besser als viele andere Zugänge die Einsicht bei den Lernenden, dass soziale Herkunft, Geschlecht, politische Ordnung, Herrschafts- und Wirtschaftsordnungen sowie Bildungsmöglichkeiten über Lebensläufe mitentscheiden und auch gesellschaftliche und gemeinschaftliche Strukturen prägen. ${ }^{32}$ Ein solcher Zugang fordert dazu auf, sich wesentlich stärker auf Schwerpunktsetzungen eines einzelnen Phänomens einzulassen und die Beschäftigung mit Überblickswissen, weniger in den Mittelpunkt zu rücken, jedoch zur Einordnung der Phänomene zu nutzen. ${ }^{33}$

Die Merkmale eines guten und gelungenen Geschichtsunterrichts zeigen sich darüber hinaus auch in der Auseinandersetzung mit den fachdidaktischen Prinzipien nach Michael Sauer, ${ }^{34}$ welcher fünf $\mathrm{zu}$ unterscheidende Unterrichtsprinzipien identifiziert hat: die Alteritätserfahrung, das Fremdverstehen und das interkulturelle Lernen, die Multiperspektivität und die Kontroversität, die Personalisierung und die Personifizierung, die Handlungsorientierung und der Gegenwartsbezug.

Die Alteritätserfahrung, das Fremdverstehen und das interkulturelle Lernen treffen sich in dem Vorgang, dass den Schülerinnen und Schülern bei der Beschäftigung mit historischen Gegebenheiten eine ihnen fremde Welt entgegen tritt. ${ }^{35}$ In der Auseinandersetzung mit historischen Prozessen wird ihnen die Chance eröffnet, ein Verständnis für andere Denkweisen und Wertvorstellungen $\mathrm{zu}$ entwickeln, das eigene Selbstverständnis zu relativieren oder auch $\mathrm{zu}$ festigen. Alteritätserfahrung ist damit auch ein wesentliches Element des interkulturellen Lernens. Es geht darum, sich mit Ernsthaftigkeit auf die Zeit, mit der man sich beschäftigt, einzulassen, um nicht nur vergangene Handlungen zu bewerten, sondern zu rekonstruieren und damit die Beweggründe und Inte-

31 Vgl. Michele Barricelli: Darstellungskonzepte von Geschichte im Unterricht, in: Michele Barricelli, Martin Lücke (Hrsg.): Handbuch. Praxis des Geschichtsunterrichts, Band 2, Schwalbach 2012, S. 202-223, hier S. 219.

32 Vgl. Ebd., S. 221.

33 Vgl. Henke-Bockschatz: Forschend-entdeckendes Lernen, S. 19-20.

34 Vgl. Michael Sauer: Geschichte unterrichten. Eine Einführung in die Didaktik und Methodik, 8. Auflage, Seelze-Velber 2009.

35 Vgl. Ulrich Baumgärtner: Wegweiser Geschichtsdidaktik. Historisches Lernen in der Schule, Paderborn 2015, hier S. 69-70. 
ressen der handelnden Personengruppen, ihre Denkweisen, Überzeugungen und Weltbilder, ihre Lebensformen und spezifischen Verhaltensmuster zu untersuchen und zu verstehen. ${ }^{36}$

In Bezug auf die Lernspiel-App vollzieht sich dieser Vorgang während des gesamten Spiels, indem sich die Schülerinnen und Schüler im Prozess des „Forschend-entdeckenden Lernens" ${ }^{37}$ aktiv mit einem vergangenen Gemeinschaftsmodell auseinandersetzen. Anhand der gestellten Aufgaben rekonstruieren sie historische Prozesse und erkennen dabei, dass sich deren Andersartigkeit immer auch in Teilen aus früheren Strukturen entwickelt hat. Fremdverstehen bedeutet daher, die mentale Disposition der drei Charaktere zu rekonstruieren, nach Motiven für die Verführbarkeit von Hans und den Widerstand von Maria zu suchen oder Gründe für die Ausweglosigkeit von Lea zu finden und diese mit dem eigenen relativen Selbstverständnis abzugleichen. Das dabei entstehende Dilemma zwischen Universalismus und Relativismus sollte bewusst verhandelt werden. Es geht daher nicht darum, alles nach heutigen Maßstäben zu messen oder alles aus zeitgenössischer Perspektive zu entschuldigen. ${ }^{38}$

Die Betonung von Multiperspektivität und Kontroversität verdeutlicht als zweite Kategorie der herauszustellenden Unterrichtsprinzipien, dass die Geschichte häufig aus einer bestimmten Perspektive überliefert wird, sodass sich Wahrnehmungen je nach Situation, Interesse oder Denkweise der Beteiligten in einem nicht unerheblichen Maße unterscheiden können. Ziel des Geschichtsunterrichts sollte es daher sein, die Schülerinnen und Schüler zur Einsicht zu führen, dass historische Ereignisse schon von den jeweiligen Zeitgenossen unterschiedlich wahrgenommen und beurteilt wurden, sodass geschlussfolgert werden kann, dass sich dieser Vorgang auch in den jeweiligen Quellen niederschlägt. Es zeigt sich, dass es nicht „die eine richtige Geschichte“ gibt, die es zu rekonstruieren gilt, sondern dass die jeweiligen Quellen nach ihrer Standortgebundenheit, also ihrer Einbettung in die soziale, räumliche, kulturelle, politische und gesellschaftliche Umgebung befragt werden müssen. Diese auf die Betrachter bezogene Multiperspektivität wird seitens der Didaktik als Kontroversität bezeichnet. ${ }^{39}$

Im Spiel zeigt sich dieser Prozess besonders deutlich mithilfe der zu leistenden Quellenarbeit, die die jeweiligen Tandems im Spielverlauf absolvieren müssen, um zu den benötigten Profilinformationen zu gelangen. Da es sich bei den zu untersuchenden Dokumenten um historische Quellen handelt, die

36 Vgl. Sauer: Geschichte unterrichten, S. 76.

37 Hasselhorn, Gold: Pädagogische Psychologie, S. 289-290.

38 Vgl. Sauer: Geschichte unterrichten, S. 77-81.

39 Vgl. Ebd., S. 81-85. 
lediglich auf die im Spiel relevanten Personendaten von Hans, Lea und Maria angepasst wurden, können die Spielenden sich im Umgang mit Perspektivität und Kontroversität erproben. Sie betrachten die unterschiedlichen Quellen hinsichtlich ihrer Entstehung, reflektieren ihre jeweilige Standortgebundenheit und werden sich darüber bewusst, dass auch ihre eigenen Deutungen einer zeitlichen und situationsabhängigen Kontroversität unterliegen.

Auch die Personalisierung und die Personifizierung spielen nach Sauer als fachdidaktische Prinzipien eine wichtige Rolle. Bis in die 1960er Jahre bestand der Geschichtsunterricht zu weiten Teilen aus Aktionsbeschreibungen großer Männer. Deren Handlungen, Absichten und Eigenschaften rückten in den Mittelpunkt der Geschichtsvermittlung. Im Zuge einer Kritik an der ausschließlich personenzentrierten Vermittlung rückte diese in den darauffolgenden Jahren immer weiter in den Hintergrund und es eröffnete sich eine neue strukturgeschichtliche Perspektive, bei der die handelnden Personen weniger von Interesse waren. Grundsätzlich ergibt es jedoch wenig Sinn, sich auf die eine oder andere Perspektive zu beschränken. Es scheint daher sinnvoll ein Wechselverhältnis zwischen handelnden Akteuren und Strukturen vorzunehmen. ${ }^{40}$

\section{Fazit}

Es zeigt sich, dass zahlreiche Argumente für einen Einsatz der App im Klassenzimmer sprechen, sofern bestimmte Voraussetzungen erfüllt werden. So braucht es in erster Linie ein Mindestmaß an Medienkompetenz und den Willen der unterrichtenden Lehrkraft, sich auch auf ein digital geprägtes Projekt einzulassen, um gemeinsam mit den Schülerinnen und Schülern eine neue Perspektive des historischen Lernens einzunehmen. In Anlehnung an die Umfrage von Bitkom Research, dass Tablets lediglich von 3 Prozent der Lehrkräfte regelmäßig genutzt werden, diese aber mehrheitlich der Meinung sind, dass Deutschlands Schulen bei der Digitalisierung hinterherhinken, kann hier eine Schnittstelle zwischen einem unkomplizierten Einsatz von digitalen Endgeräten und einer sinnvollen didaktischen Umsetzung mittels einer Lernspiel-App gezogen werden. ${ }^{41}$

Neben einer Einbettung der Tablets in den Unterrichtsablauf sollte sich die Lehrkraft mit dem aktuell in der Forschung diskutierten fachwissenschaftlichen Inhalt vertraut machen und sich mit dem nationalsozialistischen Modell der, Volksgemeinschaft ${ }^{\prime}$ und dessen Verflechtungen inhaltlich sicher genug

40 Vgl. Sauer: Geschichte unterrichten, S. 85-88.

41 Vgl. Pressebericht von Bitkom Research. 
fühlen, um die relevanten, vom Lernspiel thematisierten Aspekte aufgreifen zu können. So zeigt dieses Unterrichtskonzept das Potenzial auf, nicht mehr bloß den Staat gegen die Gesellschaft auszuspielen, da es nicht nur nach „Widerstand und Resistenz" sucht oder in der Trias "Täter - Opfer - Zuschauer“42 ein, in allen Einzelheiten differenziertes, Schema für die Erklärung sozialen Verhaltens begreift. Es geht vielmehr darum, durch eine Auseinandersetzung mit der Thematik ein differenziertes Verständnis über die Gesellschafts- und Gemeinschaftsvorstellungen $\mathrm{zu}$ entwickeln und $\mathrm{zu}$ verstehen, wie die nationalsozialistischen Strukturen in diese eingebettet wurden. ${ }^{43}$ So kann diese Form des historischen Lernens, welche eine methodische Vielfalt generiert und motivationale Aspekte des Spielens integriert, die jeweiligen Kompetenzen fördern und einen Lernzuwachs bei den Schülerinnen und Schülern erreichen.

Für die im ersten Jahr der Appentwicklung viel diskutierte Frage, ob es sich bei den im Spiel verwendeten Quellen um fiktive oder reale Quellen handeln soll, wurde an einer vergleichsweise leicht umzusetzenden und für alle Seiten akzeptablen Lösung gearbeitet, indem die Quellen, wie Fotoaufnahmen, Videosequenzen, Ausweis- oder Verwaltungsdokumente auf der Benutzeroberfläche unverändert und die fiktiven Quellen in einem Comicstil dargestellt wurden. Die Schülerinnen und Schüler können so mithilfe des Spiels, welches eine fiktive aber historisch mögliche Geschichte erzählt, anhand von echtem Quellenmaterial historische Prozesse rekonstruieren und eine Unterscheidung in der Authentizität des Materials erkennen.

Letztlich war es natürlich ein nicht immer einfacher Weg, den das gesamte Team in den drei Jahren Projektarbeit gegangen ist. Es wurde diskutiert und aneinander vorbeigeredet, es gab Missverständnisse und Kommunikationsprobleme, die sich bereits bei der unterschiedlichen Definition von Fachwörtern gezeigt haben. Sofern alle Projektbeteiligten jedoch bereit sind, nicht nur auf ihre eigenen Arbeitsweisen zu schauen, sondern sich auch für andere Disziplinen zu öffnen, können neben der Entwicklung zahlreicher neuer Ideen auch interdisziplinäre Arbeitswege enorm verkürzt werden. Mit dem Blick in eine digitale Zukunft, stehen auch die Geisteswissenschaften vor dieser Herausforderung ihre manchmal noch durchschimmernden Bedenken vor digitalen Technologien abzubauen und sich beispielsweise auch im Bereich der Informatik stärker zu professionalisieren.

Sicherlich wäre es auch für die Konzeption der Lernspiel-App ein unschlagbarer Vorteil gewesen, ein grundlegendes Verständnis über Programmierungsprozesse zu haben, um so noch tiefer in die Materie eindringen zu können. So ist zu überlegen, ob es sich nicht auch in bestimmten Bereichen - sei es

42 Hilberg: Täter, Opfer, Zuschauer.

43 Vgl. Wildt: „Volksgemeinschaft“, S. 107. 
auch nur als ein freiwilliges Wahlmodul - anbieten würde, die Aneignung von grundlegenden IT-Kenntnissen bereits in das Studienangebot für Geisteswissenschaften $\mathrm{zu}$ integrieren, um eine Sensibilisierung für grundlegende ITProzesse zu generieren, die den Weg in eine solche interdisziplinäre Arbeitsweise aufzeigen könnten.

Die Entwicklung einer Lernspiel-App für den Geschichtsunterricht, die didaktische Erprobung, das damit verwobene Aufbrechen von starren LehrMethoden und die damit einhergehende Öffnung für die Neuen Medien und Technologien kann somit bereits in der Lehrerinnen- und Lehrerausbildung einen wertvollen Beitrag für eine zukunftsfähige Bildungsarbeit leisten. So ergibt sich auf Dauer die große Chance, dass sich Disziplinen, die sich bislang nur selten miteinander verknüpfen, endlich häufiger Überschneidungspunkte haben und somit alle bei den zukünftigen interdisziplinären Herausforderungen voneinander profitieren können.

Abschließend kann herausgestellt werden, dass die gängige Art der Thematisierung des Nationalsozialismus im Schulunterricht und der damit einhergehende erzieherische Effekt es nicht immer schaffen, einen reflektierten Umgang mit Stereotypen und Vorurteilen zu generieren. Um diesem Phänomen aktiv entgegenzuwirken und bei den Lernenden ein reflektierendes Geschichtsbewusstsein auszubilden, bedarf es eines Umdenkens in der Vermittlung dieser essenziellen Lerninhalte. Dem Unterricht muss es gelingen, die Schülerinnen und Schüler in ihrer mittlerweile digital geprägten Lebenswelt abzuholen. ${ }^{44}$ Die Lernspiel-App „Sie heißt jetzt Lotte!“ soll jedoch kein Universalkonzept für das historische Lernen im Unterricht darstellen, sondern vielmehr als eine Ergänzung zum konventionellen Unterricht verstanden werden, indem der Versuch unternommen wird, den Weg in die digitale Welt zu beschreiten.

\section{Quellen- und Literaturverzeichnis}

Michele Barricelli: Darstellungskonzepte von Geschichte im Unterricht, in: Michele Barricelli, Martin Lücke (Hrsg.): Handbuch. Praxis des Geschichtsunterrichts, Band 2, Schwalbach 2012, S. 202-223.

Ulrich Baumgärtner: Wegweiser Geschichtsdidaktik. Historisches Lernen in der Schule, Paderborn 2015.

44 Vgl. Gerhard Henke-Bockschatz: Der „Holocaust“ als Thema im Geschichtsunterricht. Kritische Anmerkungen, in: Wolfgang Meseth, Matthias Proske, Frank-Olaf Radtke (Hrsg.): Schule und Nationalsozialismus. Anspruch und Grenzen des Geschichtsunterrichts, Frankfurt am Main 2004, S. 298-322, hier S. 310 f. 
Klaus Bergmann: Multiperspektivität, in: Ulrich Mayer, Hans-Jürgen Pandel, Gerhard Schneider (Hrsg.): Handbuch. Methoden im Geschichtsunterricht, 4. Auflage, Schwalbach/Ts. 2013, S. 65-77.

Marcus Hasselhorn, Andreas Gold: Pädagogische Psychologie. Erfolgreiches Lernen und Lehren, 3. Auflage, Stuttgart 2013.

Anna-Rosa Haumann: Edutainment-Apps im Geschichtsunterricht. Eine didaktische Untersuchung am Beispiel der historischen Lernspiel-App „Sie heißt jetzt Lotte!“, unveröffentlichte Masterarbeit, Erfurt 2017.

Gerhard Henke-Bockschatz: Der „Holocaust“ als Thema im Geschichtsunterricht. Kritische Anmerkungen, in: Wolfgang Meseth, Matthias Proske, Frank-Olaf Radtke (Hrsg.): Schule und Nationalsozialismus. Anspruch und Grenzen des Geschichtsunterrichts, Frankfurt am Main 2004, S. 298-322.

Gerhard Henke-Bockschatz: Forschend-entdeckendes Lernen, in: Ulrich Mayer, HansJürgen Pandel, Gerhard Schneider (Hrsg.): Handbuch. Methoden im Geschichtsunterricht, 4. Auflage, Schwalbach/Ts. 2013, S. 15-29.

Raul Hilberg: Täter, Opfer, Zuschauer. Die Vernichtung der Juden 1933-1945, 5. Auflage, Frankfurt am Main 1992.

Paul Hoser: Völkischer Beobachter, in: Historisches Lexikon Bayerns. https://www.hist orisches-lexikon-bayerns.de/Lexikon/Völkischer_Beobachter.

Kultusministerkonferenz [KMK]: Medienbildung in der Schule, 03/2012. https://www.kmk. org/fileadmin/veroeffentlichungen_beschluesse/2012/2012_03_08_Medienbildung.pdf.

Kultusministerkonferenz [KMK]: Strategie der Kultusministerkonferenz „Bildung in der digitalen Welt", 12/2016. https://www.kmk.org/fileadmin/Dateien/pdf/PresseUndAktuel les/2017/Strategie_neu_2017_datum_1.pdf.

Martin Lorber, Thomas Schutz: Gaming für Studium und Beruf. Warum wir lernen, wenn wir spielen, Berlin 2016.

Ingrid Paus-Hasebrink, Jan-Hinrik Schmidt, Uwe Hasebrink: Zur Erforschung der Rolle des Social Web im Alltag von Heranwachsenden, in: Dies. (Hrsg.): Heranwachsen mit dem Social Web. Zur Rolle von Web 2.0-Angeboten im Alltag von Jugendlichen und jungen Erwachsenen, 2. Auflage, Düsseldorf 2011, S. 13-40.

Pressebericht von Bitkom Research im Auftrag des Digitalverbands Bitkom: „Lehrer sehen deutsche Schulen digital abgehängt" vom 12.03.2019. https://www.bitkom.org/Presse/ Presseinformation/Lehrer-sehen-deutsche-Schulen-digital-abgehaengt.

Michael Sauer: Geschichte unterrichten. Eine Einführung in die Didaktik und Methodik, 8. Auflage, Seelze-Velber 2009.

Detlef Schmiechen-Ackerman: „Volksgemeinschaft“: Mythos der NS-Propaganda, wirkungsmächtige soziale Verheißung oder soziale Realitäten im „Dritten Reich“? - Einführung, in: Ders. (Hrsg.): „Volksgemeinschaft“: Mythos der NS-Propaganda, wirkungsmächtige soziale Verheißung oder soziale Realitäten im „Dritten Reich“?, Paderborn 2012, S. 13-53.

Alexa Stiller: Sammelrezension: Fiktion und Realität der „Volksgemeinschaft“, in: H-SozKult (18.07.2013), S. 1 ff. http://www.hsozkult.de/publicationreview/id/rezbuecher-17158.

Dietmar Süß, Winfried Süß: „Volksgemeinschaft“ und Vernichtungskrieg. Gesellschaft im nationalsozialistischen Deutschland, in: Dies. (Hrsg.): Das „Dritte Reich“. Eine Einführung, München 2008, S. 79-119. 
Völkischer Beobachter vom 28. Februar 1933 aus Anlage 9. 2, aus: Stadtarchiv München, Völkischer Beobachter vom 28. Februar 1933, 1.

Michael Wagner: Serious Games: Spielerische Lernumgebungen und deren Design, in: Paul Klimsa, Ludwig J. Issing (Hrsg.): Online Lernen. Handbuch für Wissenschaft und Praxis, 2. Auflage, München 2011, S. 297-305.

Annekathrin Wetzel: Sie heißt jetzt Lotte!, Drehbuch, München 2013.

Annekathrin Wetzel: „Sie heißt jetzt Lotte!“, Regie und Drehbuch: Annekathrin Wetzel, DE: MiriquidiFilm 2014, Fassung: Internet. http://www.bild.de/unterhaltung/kino/kurzfilm /sie-heisst-jetzt-lotte-bei-bild-de-38538352.bild.html.

Michael Wildt: „Volksgemeinschaft“. Eine Antwort auf Ian Kershaw, in: Zeithistorische Forschungen/ Studies in Contemporary History, Online-Ausgabe 8 (2011) 1, S. 102-109. http://www.zeithistorische-forschungen.de/1-2011/id=4756. 
Johannes Blavius / Martin Just

\section{Konzeption und Einsatzmöglichkeiten einer Personaldatenbank zur Aufarbeitung von NS-Verbrechen am Beispiel des Konzentrationslagerkomplexes Mittelbau-Dora}

"Die Zeitgeschichte steht vor einer Zeitenwende - und merkt es nicht... " Die Geschichtswissenschaft, als Teil der Geisteswissenschaften, hat bis heute einen geringeren Nutzen aus dem digitalen Wandel gezogen als andere Wissenschaften, konstatierte Guido Koller im Jahr 2016. ${ }^{2}$ Der digitale Wandel ermöglicht es der Geschichtswissenschaft theoretisch, auf Datenmengen zurückzugreifen, die mit klassischen Methoden nicht oder nur mit immensem Aufwand ausgewertet und narrativ verarbeitet werden könnten. Die Wissenschaft bewegt sich heute im Rahmen von Big Data ${ }^{3}$ und wird sich den veränderten Gegebenheiten zunehmend anpassen müssen, wenn sie einen größtmöglichen Nutzen aus den digitalen Möglichkeiten ziehen möchte. ${ }^{4}$

\section{Ausgangslage}

Dass sich eine herkömmliche geschichtswissenschaftlich-methodische Vorgehensweise für ein Projekt, welches viele Datensätze benötigt, um neue Erkenntnisse zu generieren, nicht eignet, zeigte sich in der Bachelorarbeit der beiden Autoren. Die potentiell verfügbaren Datenmengen überstiegen die Möglichkeiten einer klassischen Herangehensweise deutlich. Die Bachelorarbeit beschäftigte sich mit einem nationalsozialistischen Konzentrationslager im

1 Kiran Klaus Patel: Zeitgeschichte im digitalen Zeitalter. Neue und alte Herausforderungen, in: Vierteljahrshefte für Zeitgeschichte 59 (2011), S. 331-352, hier S. 331.

2 Guido Koller: Geschichte digital. Historische Welten neu vermessen, Stuttgart 2016, S. 65.

3 Zum Begriff Big Data: Kai Grönke, Markus Kirchmann, Jörg Leyk: Big Data Auswirkungen auf Instrumente und Organisation der Unternehmenssteuerung, in: Ronald Gleich u. a. (Hrsg.): Controlling und Big Data. Anforderungen, Auswirkungen, Lösungen, München 2014, S. 63-82, hier S. 65-67.

4 Koller: Geschichte digital, S. 65. 
Südharz und fokussiert auf eine Quelle, die Daten zum Personal des Konzentrationslagerkomplexes Mittelbau-Dora beinhaltet. Besagte Quelle listet 2.178 Personen, die von US-amerikanischen Einheiten in der unmittelbaren Nachkriegszeit bei Ermittlungen zu Kriegsverbrechen im Dritten Reich dem Lagerpersonal zugeordnet worden waren. Die Quellen, welche der von den USTruppen erstellten Liste zugrunde liegen, sind nur noch zu einem kleinen Teil direkt einsehbar oder werden im National Archive in Washington bewahrt und befinden sich somit für Studierende mit begrenzten monetären und zeitlichen Mitteln außer Reichweite. Im Rahmen der Analyse der Liste und der Einarbeitung zusätzlich recherchierter personenbezogener Informationen wurden schnell methodische Grenzen sowie der Bedarf einer digitalen Datenverarbeitung erkennbar. Aus dieser Erkenntnis resultierend entstand die Idee, eine themenbezogene Datenbank zu entwickeln, um die Menge an personenbezogenen Daten effektiv nutzbar machen zu können. Zu diesem Zeitpunkt ließ sich nur erahnen, welche Möglichkeiten die Digitalisierung auch für studentische Projekte eröffnet. Fachwissenschaftlich mit dem nötigen Know-how ausgestattet und vor dem Hintergrund der methodischen Grenzen der klassischen Arbeitsweisen, wuchs die Idee sich in digitales Neuland zu begeben und die Thematik neu zu denken. Das Geschichtsstudium hatte im Bachelor nur wenige Bezüge zu digitalen Arbeitsweisen geboten und gerade im Curriculum Schwächen bezüglich des digitalen Arbeitens offenbart. Die Idee, die in der Bachelorarbeit beleuchtete Quelle als Grundlage für eine Datenbank zu nutzen, war jedoch auch im Masterstudiengang weiter gereift, sodass die Konzeption und Umsetzung einer personenbezogenen Datenbank ins Zentrum der Masterarbeit gestellt wurde. Im Folgenden sollen nun die projektbezogenen Herangehensweisen sowie die aus der Arbeit gewonnen Erfahrungen geschildert werden.

\section{Konzeption und perspektivische Anwendungsmöglichkeiten der Datenbank}

$\mathrm{Zu}$ Beginn eines solchen Projektes ist es unumgänglich, sich mit der Frage auseinanderzusetzen, was unter einer Datenbank im engeren Sinne zu verstehen ist und welche Daten verarbeitet werden sollen.

Wird eine Datenbank als „eine Sammlung von Daten, die untereinander in einer logischen Beziehung stehen und von einem eigenen Datenbankverwaltungssystem [...] verwaltet werden " ${ }^{5}$ begriffen, sollte es Ziel der Masterarbeit

5 Edwin Schicker: Datenbanken und SQL. Eine praxisorientierte Einführung mit Anwendungen in Oracle, SQL Server und MySQL, 5. Auflage, Wiesbaden 2017, S. 3. 
sein, ein System zu entwickeln, das zum Sammeln, Katalogisieren, Verwalten und Auswerten von personenbezogenen Daten geeignet ist. Denn nur ein solches System erlaubt eine effiziente, komplexe und forschungsgeleitete Auswertung der gesammelten Informationen. Hierbei ging es primär nicht darum, das Lagerpersonal des Komplexes Mittelbau-Dora erschöpfend zu erforschen, sondern ein Werkzeug für Historikerinnen und Historiker zu konzipieren, welches der wissenschaftlichen Forschung Analysen zum Personal des Lagerkomplexes Mittelbau-Dora ermöglicht und in einem weiteren Schritt auch für die Erforschung anderer Konzentrationslager dienlich sein kann.

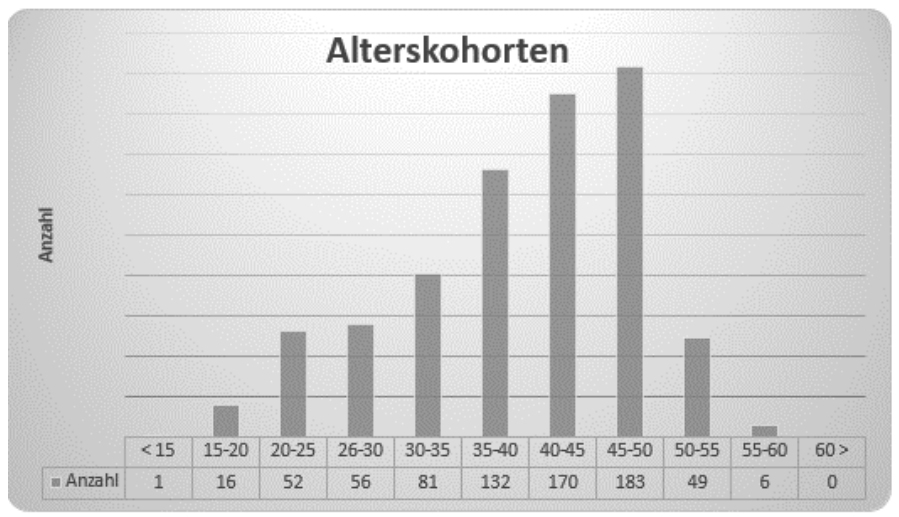

Abbildung 1: Durch das System errechnete Alterskohorten des Lagerpersonals.

Ausgangspunkt des Projekts war somit die Frage nach der Sinnhaftigkeit einer Datenbank und der damit verbundenen methodischen Herangehensweise. Das klassische geschichtswissenschaftliche Vorgehen hätte Fragen an die historische Quelle gestellt und die daraus resultierenden Antworten in einer festen Narration verarbeitet und final einen Forschungstand präsentiert. Im vorliegenden Fall hätte die Liste mit 2.178 gelisteten Personen als Anhaltspunkt für weitere Recherchen zum Lagerpersonal dienen können. Aufgrund der Liste ließe sich feststellen, welche Person - identifizierbar durch die auf der Liste vermerkten Rang- und Geburtsdaten - welche Einsatzorte durchlaufen hat. Es ist also durchaus möglich, der klassischen Vorgehensweise folgend, Fragen an die Quelle zu stellen. Welche Person war in welchem Lager des Konzentrationslagerkomplexes stationiert? Wann ist die jeweilige Person geboren und welchen Dienstgrad hatte die Person inne? Für weitergehende biographische Fragen müssten weitere Quellenbestände wie Personalakten gesichtet und ausgewertet werden. An dieser Stelle reifte das Vorhaben zur Entwicklung einer Datenbank. Alle Forschenden, die das Personal des Konzentrationslagerkomplexes Mittelbau-Dora analysieren, können die Liste in der Gedenkstätte 
und - soweit vorhanden - die zugehörigen Personalakten im Bundesarchiv Berlin einsehen und forschungsgeleitete Fragen anhand der Quellen erörtern. Dies verlangt jedoch von den Forschenden einen physischen Besuch der Archive und größtenteils das individuelle Arbeiten vor Ort.

Nehmen wir an, Historiker A beschäftigt sich mit der Frage nach dem Altersdurchschnitt im Konzentrationslagerkomplex Mittelbau-Dora und möchte das Lagerpersonal in Alterskohorten einteilen. Historikerin B betreibt Netzwerkforschung und versucht, verborgene Verbindungen herauszuarbeiten und sucht Personal des Lagerkomplexes Mittelbau-Dora, das vor dem dortigen Dienst bereits in anderen Konzentrationslagern gemeinsam stationiert war. Historikerin C forscht über den Anteil des Wachpersonals des Konzentrationslagers Mittelbau-Dora, welches der von Michael Wildt herausgearbeiteten "Generation des Unbedingten“6 zugehörig ist. Sie sucht also gezielt Personen der Jahrgänge 1900 bis 1910. In der Summe führt dies dazu, dass alle dem Beispiel zugrundeliegenden Forschenden unabhängig voneinander die Quellenbestände im Original konsultieren müssten, um ihre konkreten Fragestellungen bearbeiten zu können. Historiker A errechnet aus den 2.178 Personen der Liste die Altersdurchschnitte der Alterskohorten. Allein um den Durchschnitt bilden zu können, müsste Historiker A die Geburtsjahre der 2.178 Personen addieren und anschließend durch die Summe der Geburtsdaten dividieren. Für die Berechnung der jeweiligen Alterskohorten wäre die Mehrarbeit deutlich zeitintensiver. Historikerin B müsste die auf der Liste stehenden Personen mit den verfügbaren Personalakten abgleichen und herausarbeiten, in welchen Lagern die Personen gemeinsam eingesetzt waren. Anschließend könnte sie untersuchen, ob diese Personengruppen schnellere Karrierewege nahmen und ob alte Netzwerke dies begünstigten. Auch Historikerin C muss die Geburtsdaten von 2.178 Personen manuell vergleichen und jene herausfiltern, die Wildts "Generation des Unbedingten“ zuzurechnen sind. Resümierend für diese Beispiele ist festzuhalten, dass alle drei Forschenden unabhängig voneinander mit einem ähnlichen Quellenbestand operieren. Für Historiker A und Historikerin $\mathrm{C}$ sind die Geburtsdaten von besonderem Interesse. Beide würden viel Zeit darauf verwenden, die Quelle mit den 2.178 Namen und den auf ihr vermerkten Daten händisch auszuwerten. Hier wird deutlich, welche Vorteile eine Datenbank in einem solchen Falle bieten kann. Wäre die Liste mit Namen, Einsatzorten, Geburtsdaten und Dienstgraden des Lagerpersonals in eine Datenbank aufgenommen, könnte an dieser Stelle immens Arbeitszeit eingespart und diese dann für tiefergehende Analysen genutzt werden. Historiker A und Historikerin C könnten sich durch das System in wenigen Sekun-

6 Vgl. Michael Wildt: Generation des Unbedingten. Das Führungskorps des Reichssicherheitshauptamtes, Hamburg 2002. 
den die Geburtsdaten auswerten lassen. Historikerin C könnte darüber hinaus ihre Suche in einer forschungsgerecht konzipierten Datenbank direkt auf die von ihr beleuchteten Jahrgänge 1900 bis 1910 eingrenzen und alle anderen Personen ausblenden. Historikerin B wäre mit einem Datenbanksystem in der Lage, gezielt auf ihre Fragestellung angepasst nach Personen zu suchen, welche vor ihrer Zeit in Mittelbau-Dora auch in anderen Lagern stationiert waren. Selbstverständlich sind diese Fragestellungen in Bezug auf die 2.178 Namen umfassende Liste aus dem ehemaligen Konzentrationslager Mittelbau-Dora auch mit klassisch-händischen geschichtswissenschaftlichen Methoden zu beantworten, jedoch muss gerade in Bezug auf den Lagerkomplex im Südharz von mehr als 3.000 als Lagerpersonal eingesetzten Personen ausgegangen werden. ${ }^{7}$ Bei diesen Größenordnungen stößt eine klassische, nicht rechnergestützte Methode zunehmend an ihre Grenzen. Umso mehr, wenn die Forschungsperspektiven auf das gesamte Konzentrationslagersystem ausgeweitet und somit zehntausende Personen in den Fokus der Forschung gerückt werden würden.

Diese einfachen Beispiele verdeutlichen die Vorteile, die selbst eine marginale digitale Datenverarbeitung für die Geschichtswissenschaft bietet. Einmal in der Datenbank erfasst, lassen sich die Daten beliebig oft abfragen und auch auf verschiedene Forschungsfragen angepasst sortieren und katalogisieren. Die klassische Quellensuche im Archiv und die nachfolgende Analyse können somit essentiell vereinfacht werden.

Was gilt es nun zu beachten, wenn ein solches für geschichtswissenschaftliche Fragestellungen unterstützendes System erstellt werden soll? Vor der Konzeption der Datenbank sind zentrale Fragen in den Blick zu nehmen. Welche potentiellen wissenschaftlichen Fragestellungen sollen mit der Datenbank bearbeitet werden? Welche Quellenbestände und Informationen sollen gespeichert werden? Wo liegen die zukünftigen Anwendungsbereiche der Datenbank? Die Überlegung, welche Daten in der Datenbank erfasst werden sollen und das daraus resultierende Datenbankmodell sind sowohl im Hinblick auf mögliche wissenschaftliche Fragestellungen als auch für die Programmierung essentiell. Daten, die im Konzept nicht vorgesehen sind, können nur unter großem Aufwand nachträglich hinzugefügt werden und nicht vorhandene Daten können ebenso nicht der Beantwortung einer potentiellen wissenschaftlichen Fragestellung dienen. ${ }^{8}$ Die Auslotung zukünftiger Fragestellungen sollte

7 Jens-Christian Wagner: Ellrich 1944/45. Konzentrationslager und Zwangsarbeit in einer deutschen Kleinstadt, Göttingen 2009, S. 119.

8 Holger Gast, Antonia Leugers, August Leugers-Scherzberg: Optimierung historischer Forschung durch Datenbanken. Die exemplarische Datenbank Missionsschulen 1887-1940, Bad Heilbrunn 2010, S. 14. 
in interdisziplinärer Zusammenarbeit und im engen Austausch mit Gedenkstätten- und Archivpersonal erfolgen, um keine potentiell notwendigen Daten außer Acht zu lassen. Hierbei müssen auch der Forschungsstand, aktuelle Forschungsperspektiven und -desiderate der jeweiligen Disziplin betrachtet werden.

Für die Personaldatenbank wurden hierfür sowohl die Forschungsstände der NS-Täterforschung als auch die Konzentrationslager- und Verwaltungsgeschichte dieses komplexen Apparates analysiert. Speziell sollten im Falle der Realisierung der Personaldatenbank neben dem Wachpersonal auch gezielt das Verwaltungspersonal erfasst werden und unter biographischen Gesichtspunkten Daten verarbeitet werden. Neueste Forschungsschwerpunkte der NSTäterforschung flossen folglich in das Datenbankkonzept mit ein.

Mögliche Fragestellungen, welche bei der Konzeption berücksichtigt wurden, reichen vom sozialen Herkunftsmilieu, von der schulischen Ausbildung, dem politischen und militärischen Werdegang, dem Einsatz im Lagersystem bis zu den eventuell aus den NS-Verbrechen resultierenden Gerichtsverfahren in der Nachkriegszeit. Auch der Werdegang und die Karrieren nach 1945 wurden in das Konzept aufgenommen. Diese in das Datenbankkonzept integrierten Themenbereiche wurden hinsichtlich Verfügbarkeit von Quellen, ihrer Verarbeitung und möglicher visueller Darstellung durchdacht.

Die späteren Einsatzfelder der Datenbank mussten vorab ausgelotet werden. Ist die Datenbank rein für den wissenschaftlichen Gebrauch an Universitäten oder soll sie auch im Bereich der öffentlichen Bildung, an Schulen oder Gedenkstätten einsetzbar sein?

Im Falle der Personaldatenbank Mittelbau-Dora wurde auch der Einsatz im schulischen Bereich im Konzept verankert und wurden erste konkrete Umsetzungsvorschläge erarbeitet, sodass die Datenbank einer möglichst breiten Öffentlichkeit zur Verfügung stehen könnte.

Nach der Erörterung potentieller Fragestellungen und Einsatzbereiche war es notwendig, die Quellen zu konsultieren, um zu prüfen, ob die Quellenbestände eine Bearbeitung der diskutierten Fragestellungen überhaupt zulassen.

Im Falle der Personaldatenbank des Lagerkomplexes Mittelbau-Dora wurden sowohl Quellenbestände der KZ-Gedenkstätte in Nordhausen als auch einschlägige Quellenbestände des Bundesarchives Berlin gesichtet und deren inhaltliche Aussagekraft für die Personaldatenbank geprüft. Diesem Schritt sollte auch hinsichtlich der Zeitplanung eines Datenbankprojektes genügend Zeit eingeräumt werden, da er sich als essentiell für die folgende Konzeption erweist.

Nachdem der thematische Rahmen abgesteckt, die Nutzungsreichweite der Datenbank erörtert und die Quellen konsultiert waren, konnte mit der eigent- 
lichen Umsetzung des Projektes, mit der konkreten Konzeption des Datenbankdesigns, begonnen werden. In dieser Projektphase stießen wir auf verschiedenste Herausforderungen, die vor allem in der interdisziplinären Natur eines solchen Projektes begründet lagen. In der Regel verfügen Studierende der Geschichtswissenschaft studienbedingt nur über ein begrenztes Know-how im IT-Bereich und scheuen daher oft die Auseinandersetzung mit den Innovationen des digitalen Zeitalters. Wenngleich die Digital Humanities hierfür Abhilfe schaffen, so halten deren Inhalte nur zögerlich Einzug in die Curricula der Universitäten.

Auch im Falle der Personaldatenbank Mittelbau-Dora beschränkte sich die Expertise des Projektteams anfangs auf die Bereiche Geschichts-, Sozial- und Religionswissenschaft. Folglich war es für das Gelingen der Konzeption elementar, sich die für das Projekt wichtigen IT-Grundlagen anzueignen. Hierbei ging es nicht darum, die notwendigen Programmiersprachen zu lernen oder ein mehrsemestriges Informatikstudium nachzuholen, sondern vielmehr darum, Datenbanken und deren Funktionsweise an sich zu verstehen. Hierfür empfahlen sich einschlägige Lehrbücher der Informatik, wobei mit der Grundlagenlektüre keine umfassenden Programmierkenntnisse erworben werden können. Dies zeigte jedoch vor allem, dass ein interdisziplinäres Projekt auch eine interdisziplinäre Expertise erfordert. Eine solche Expertise findet sich nur in Ausnahmefällen an der eigenen Fakultät, weshalb der Blick zwangsläufig über das eigene Studienfach hinausgehen musste. Es bot sich an, mit für solche Projekte aufgeschlossenen Dozierenden zu sprechen, um Kontakt zu Informatikerinnen oder Informatikern herzustellen. Da gerade während eines Informatikstudiums die Studierenden immer wieder auf der Suche nach anspruchsvollen und interessanten Projekten sind, die sowohl eine Herausforderung als auch eine Horizonterweiterung darstellen, bot es sich an, den Fokus auf andere Universitäten - insbesondere technische - sowie Fachhochschulen zu lenken. Jedes Semester suchen Studierende disziplin-unabhängig vielversprechende und nachhaltige Themen für ihre Abschlussarbeiten. Hier bot sich die Chance für eine interdisziplinäre Verknüpfung von Arbeiten, was sich auch in Bezug auf die Projektfinanzierung als vorteilhaft erwies. Nur wenige studentische Projekte sind finanziell so ausgestattet, einen externen Programmierer über längere Zeit beschäftigen zu können. Auch die Realisierung der Personaldatenbank Mittelbau-Dora wäre an der Finanzierung gescheitert, hätte sich nicht ein vielversprechender Kontakt zu einem Studierenden im Informatikbereich der Universität Leipzig ergeben.

Nachdem der Kontakt hergestellt und die wichtigsten Projektziele besprochen waren, stellte sich das komplexe Wechselspiel zwischen Informatik und Geschichtswissenschaft als die zentrale Herausforderung dar. Die von der 
Geschichtswissenschaft vorgesehenen Methoden und Konzepte müssen von der Informatik auf deren Realisierbarkeit hin geprüft werden. In der einen Richtung müssen Historikerinnen und Historiker den Programmierenden die Ziele des Projektes und die damit verbundenen Methoden und Inhalte vermitteln. Im Umkehrschluss sind es jedoch die Programmierenden, die ihrerseits das Gewünschte umsetzen und auf Innovationsmöglichkeiten und Grenzen des Projektes hinweisen. Der Schlüssel zum Erfolg eines solchen Projektes ist die Kommunikation. Was soll umgesetzt werden? Welche Inhalte sollen in welcher Form verknüpft werden? Welche Anwendungsfälle existieren und was kann das Programm im besten Fall leisten?

Um eine möglichst zielführende, für beide Seiten verständliche Kommunikationsstruktur zu schaffen, bedienen sich interdisziplinäre Projekte der Modellierungssprache UML (Unified Modeling Language). Dies ist eine objektorientierte Sprache zur Modellierung von Softwaresystemen, mit deren Hilfe eine abstrakte Darstellung von Zusammenhängen und komplexen Systemen auf der Grundlage von Diagrammen ermöglicht wird. ${ }^{9}$

Wie eine natürliche Sprache ist die UML Regeln unterworfen und bedient sich einem komplexen Zeichen- und Symbolsystem, um Inhalte zusammenzuführen und Softwarekonzepte darzustellen. ${ }^{10}$ Auf Basis der graphischen UMLNotation können umfangreiche Konzepte entworfen werden. Hinzu kommt, dass die UML neben festen, allgemeingültigen Regeln auch über Möglichkeiten einer projektbezogenen Anpassung und Erweiterung verfügt. Die UML ermöglicht es folglich, die entworfenen Diagramme den eigenen projektspezifischen Gegebenheiten anzupassen. ${ }^{11}$ Somit diente die UML als gemeinsame Diskussionsbasis innerhalb des Projektes.

Auf dieser Basis wurde ein Datenbankkonzept entwickelt, um einerseits die komplexe Inhaltsstruktur und andererseits die Funktionsweise der Datenbank zu visualisieren. Dieses Konzept diente als Grundgerüst für die eigentliche Umsetzung der Datenbank und die Implementierung der entsprechenden Schnittstellen. Sie stellt somit einen Gegensatz zur klassischen Darstellungsform der Geschichtswissenschaft dar, die in der Regel textbasiert ist. In Bezug auf die Datenbank hätte ein solches Vorgehen bedeutet, die Konzeptionen, Anwendungsfälle und Handlungsanweisungen für die beteiligten Programmierenden auf unzähligen Seiten in Textform zu beschreiben. Dieses Vorgehen ist schon aus interdisziplinärer Sicht als unökonomisch zu erachten, da Ge-

9 Uwe Katzke: Spezifikation und Anwendung einer Modellierungssprache für die Automatisierungstechnik auf Basis der Unified Modeling Language UML (Dissertation), Kassel 2008, S. 17.

10 Dan Pilone: UML 2.0. kurz \& gut, 2. Auflage, Köln 2006, S. 9.

11 Bernhard Rumpe: Modellierung mit UML. Sprache, Konzepte und Methodik, Berlin/Heidelberg/New York 2004, S. 60f. 
schichtswissenschaft und Informatik unterschiedliche Begrifflichkeiten nutzen und jeweils eigene methodische Vorgehensweisen bevorzugen. Es wäre folglich nicht sicherzustellen gewesen, dass der Entwickler aus dieser umfassenden textbasierten Beschreibung letztlich die für ihn relevanten Informationen generieren und die Software den Vorgaben entsprechend hätte umsetzen können. Hier bot die UML als gemeinsame Kommunikationsbasis entscheidende Vorteile. Das gesamte Konzept kann in Diagrammform visuell übersichtlich und einheitlichen Regeln unterworfen dargestellt werden, sodass Kommunikationsprobleme zu einem erheblichen Teil minimiert werden konnten. Im Falle der Personaldatenbank Mittelbau-Dora wurde ein zentrales Datenbankkonzept entworfen, durch welches der Entwickler in die Lage versetzt wurde, die gewünschten Funktionen umzusetzen. Auch die Kommunikation bezüglich kleinerer Änderungen oder sinnbringender Innovationen verlief auf der Basis dieses UML-Konzeptes weitgehend spannungsfrei und in hohem Maße produktiv. Ein stetiger Austausch zwischen beiden Seiten war der Schlüssel für die erfolgreiche Umsetzung des gesamten Projektes. Wir als Geschichtswissenschaftler und Projektinitiatoren mussten die Ziele klar formulieren und mittels UML visuell abbilden, während dem Entwickler die Prüfung dieser Vorgaben hinsichtlich Realisierbarkeit und Aufwand oblag. In einem ersten Schritt wurden personenbezogene Daten in die Datenbank aufgenommen, die für die Identifikation einzelner Personen in den Dokumenten oder zur tieferen Recherche in Archiven nötig sind. Hierbei nehmen Name, Vorname, Geschlecht, Geburtsdatum und Geburtsort für eine spätere Identifikation einen übergeordneten Stellenwert ein. Die Aufnahme des Geburtsdatums und des Geschlechts dienen neben dem Zweck der Identifikation auch der Beantwortung verschiedener wissenschaftlichen Fragestellungen. Neben der Erstellung von Alterskohorten können so auch genderspezifische Fragen bearbeitet werden. Auch für den Lagerkomplex Mittelbau-Dora sind für die Spätphase weibliche SS-Aufseherinnen in geringer Zahl nachgewiesen. ${ }^{12}$

12 Auf der dem Projekt als Quellengrundlage vorrangig zugrunde liegenden Liste finden sich auch zwei Frauen mit Mannschaftsdienstgrad: Johannes Blavius, Martin Just: ,Die Liste', unveröffentlichte Masterarbeit, S. 193. Zum Einsatz von Frauen als Aufseherinnen im Lagerkomplex Mittelbau-Dora: Robert Sommer: Das KZ-Bordell. Sexuelle Zwangsarbeit in nationalsozialistischen Konzentrationslagern, 2. Auflage, Paderborn 2010, S. 157-160. 


\title{
Forster Heinrich 14.01.1897
}

Profil NS-Organisation Militärische Laufbahn Dokumente Kurzbiografie

\section{Persönliche Daten}

\author{
Geschlecht \\ männlich \\ Vorname \\ Heinrich \\ Nachname \\ Forster \\ Geburtsdatum \\ 14.01.1897 \\ Geburtsort \\ Langenaltheim \\ Konfession \\ Evangelisch \\ Gottgläubig \\ Gerichtsverfahren nach 8. Mai 1945 \\ Nein
}

\section{Familie}

Abbildung 2: Exemplarischer Datenbankeintrag.

Um die Personen detaillierter fassen und erste Details zum sozialen, religiösen und politischen Herkunftsmilieu sichtbar machen zu können, wurden in einem nächsten Schritt steckbriefartige Daten erfasst (siehe Abbildung 2). Diese beinhalten neben Angaben zu Konfession und Parteizugehörigkeit auch die jeweiligen Einsatzorte und Dienstgrade. Um die Personen einer Kategorie zuordnen zu können, mussten zudem Daten gesammelt werden, die Rückschlüsse auf die jeweilige Funktion im Lager zuließen. Hiernach wurden die Personen entweder der Wachtruppe oder der Lagerverwaltung zugeteilt. Im Falle einer Zuordnung zur Wachtruppe sind insbesondere Daten zu Dienstorten und Dienstzeiträumen sowie der jeweilige Dienstgrad und die Daten über die Zugehörigkeit zur SS von Relevanz. In Bezug auf das Verwaltungspersonal ist die Zuordnung zu einer der sechs Verwaltungsabteilungen für die Strukturierung und Beantwortung wissenschaftlicher Fragestellungen unerlässlich. Hierbei musste aufgrund der Besonderheit der Politischen Abteilung und deren personeller Zugehörigkeit zur Polizei das Verwaltungspersonal in militärisches oder polizeiliches Personal ausdifferenziert werden. Um die Rolle der, im Zuge des zunehmenden Einsatzes von Häftlingen in der Rüstungsindustrie, im 
Konzentrationslagersystem eingesetzten zivilen Mitarbeiter wie Vorarbeiter, Ingenieure und dergleichen beleuchten zu können, bildet das zivile Personal eine eigene Kategorie innerhalb der Datenbank. Hierbei dient die Aufnahme der Daten von zivilen Mitarbeitern dazu, das enge Netzwerk zwischen SS, Rüstungsbetrieben und Konzentrationslagern sichtbar zu machen.

Einige der genannten Punkte, wie beispielsweise die Parteizugehörigkeit, gliedern sich innerhalb des Konzeptes nochmals auf, um spezifisch EDVgestützte auswertbare Daten sammeln zu können. Unter dem Punkt Parteizugehörigkeit wurde zuerst eine mögliche Parteizugehörigkeit eingetragen und anschließend die Parteinummer sowie das Parteieintrittsdatum vermerkt, sodass auch hierauf basierende Rückschlüsse gezogen werden können. Selbiges trifft auf die SS-Mitgliedschaft zu. Für diese steckbriefartige Übersicht zur Person wurde auch der letzte bekannte ausgeübte Beruf oder eine etwaige Arbeitslosigkeit vor der Tätigkeit in der SS oder Polizei erfasst. Die Einsatzorte der Personen sind darüber hinaus in Haupt-, Außen- und Nebenlager kategorisiert. Wichtig war hierbei die Erfassung der Dienstzeiträume im jeweiligen Lager. Um Karrierewege nachzeichnen zu können, wurden sowohl der höchste bekannte Dienstgrad als auch vorherige Dienstgrade mit zugehörigem Beförderungsdatum vermerkt.

Im letzten Schritt wurden breite biographische Informationen in die Datenbank eingespeist, die konkrete Rückschlüsse auf das soziale Herkunftsmilieu der Personen und deren Bildungsweg zulassen (siehe Abbildung 3). Unter dem Punkt Familie sollen Daten zu Kindern, Ehepartnern und Eltern gesammelt werden, wobei auch der Beruf der Eltern mit erfasst wird. In Bezug auf die Schulbildung wird der Bildungsweg skizziert und der höchste Bildungsabschluss sowie der erlernte Beruf in die Datenbank integriert. Informationen zu Mitgliedschaften in anderen NS-Organisationen mit jeweiligen Eintrittsdaten wurden in diesem Schritt ebenso eingefügt wie Informationen zu Orden, Ehrenzeichen und deren Verleihungsdaten. Um das Personal des Konzentrationslagerkomplexes auch nach Kriegsende fassbar machen zu können, wurden allgemeine Informationen zum Verbleib der Personen nach 1945 gesammelt, wobei Gerichtsverfahren einen gesonderten Stellenwert im Datenbankkonzept erhalten. Diese Gerichtsverfahren schlüsseln sich nach Verfahrensnummer, Verfahrenszeitraum und dem etwaigen Urteil auf. Für alle Informationen, die nicht in dieses vorgegebene Raster fallen, bietet die Datenbank in vielen Unterpunkten eine Bemerkungsspalte, in der individuelle Informationen erfasst werden können, die als relevant gelten, aber im Datenbankmodell bislang unberücksichtigt sind. 


\title{
Forster Heinrich 14.01.1897
}

Profil NS-Organisation Militărische Laufbahn Dokumente Kurzbiografie

Kurzbiografie

\begin{abstract}
Familie
Forster hatte drei Geschwister und ist der Letztgeborene. Heinrich Forster heiratete am 20.05.1921 Frau Elisabeth Bülow aus Schwerin. Am 30.07.1922 wurde die gemeinsame Tochter Ursula geboren. Zwölf Jahre später kam das zweite Kind mit Namen Heinz am 28.11.1934 zur Welt. Während seiner Dienstzeit im Außenlager Drütte unterhielt Forster ein Verhältnis der ebenfalls verheirateten Margarete Schaldach.

Schulbildung / Berufsausbildung

Heinrich Forster besuchte zwischen 1903 und 1910 die Volksschule. Anschließend erlernte er an einer

Forstbildungschule von Oktober 1910 bis Oktober 1914 seinen Beruf, Forst-Landwirt.

Im Oktober meldete sich Forster als Freiwilliger im 1.Weltkrieg.

Nach seiner Entlassung, arbeitete er von 1919 bis 1924 bei der Reichsbahn in Schwerin als Betriebsassistent.

Anschließend betrieb Forster ein Tabakgeschätt, welches er 1928 verkaufte.

Zwischen 1928 und 1930 arbeitete Forster bei der Straßenbahngesellschaft BVG in Berlin. Anschließend war

Forster ein Jahr bei einem Wachschutzunternehmen beschätigt.

In der Zeit von 01.10.1931 bis 01.05.1933 war Forster arbeitslos.

Politisch / Militärischer Werdegang

Erste militärische Erfahrung sammelte Forster im 1. Weltkrieg. Er meldete sich im Alter von 18 Jahren am 15.01.1915 freiwillig zur Marine. Er wurde in Kiel stationiert. In der Zeit seiner Arbeitslosigkeit trat Forster SA. Reserve am 01.09.1931 bei bereits drei Monate spăter trat Forster in die NSDAP (01.12.1931) und anschließend die SS (15.01.1932) ein.

Ab dem 12.09.1937 wurde Forster beim SS-Sturmbann V/42 aufgestellt und dort zum SS-Untersturmführer befördert. Er war als Zugführer eingesetzt und besuchte eine 8 wöchige SS-Unterführerschule. Eine Beurteilung vom August 1938 attestiert Forster einen festen aber bescheidenen Charakter. Seine weltanschauliche Haltung wird als gefestigt beschrieben. Seine Fähigkeiten als Vorgesetzter werden als gut beschrieben.
\end{abstract}

Abbildung 3: Exemplarische Kurzbiografie.

Eine besondere Stärke des Konzeptes ist die vorgesehene Möglichkeit zur Aufnahme von bisher nicht digitalisierten Dokumenten und Quellen als Scans in die Datenbank. So können jeder Person beliebig viele Dokumente zugeordnet werden, um eine tiefere quellenorientierte Auseinandersetzung mit der Person zu ermöglichen. Mit den eingespeisten Daten und den angehängten Quellen lässt sich so im finalen Stadium der Auseinandersetzung mit einer Person eine ausformulierte Kurzbiographie erstellen, deren Wert sowohl im didaktischen als auch im wissenschaftlichen Bereich zu verorten ist. 
Profil NS-Organisation Militărische Laufbahn Dokumente Kurzbiografie

Privatsphāre-Einstellungen

\section{Einsatzorte}

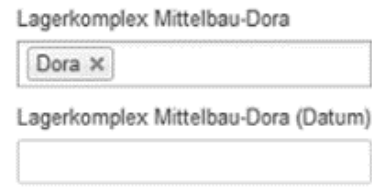

Andere Lagerkomplexe

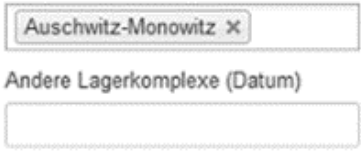

Arbeitsbereich

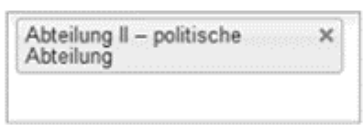

Funktion

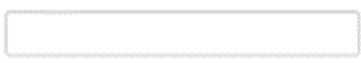

Einsatzorte (Bemerkung)

\section{Dienstgrade}

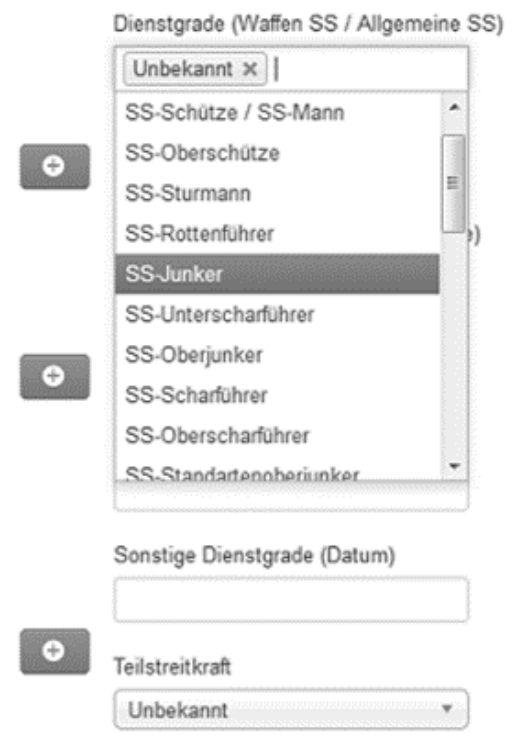

$\oplus$

$\oplus$

$\oplus$

$\odot$

Abbildung 4: Eingabefelder in der Datenbank.

Um eine Datenbank funktional und zielführend wissenschaftlich nutzbar machen zu können, stellen sich zwei weitere Fragen: Zum einen, wie es ermöglicht wird, unkompliziert und möglichst selbsterklärend eine Vielzahl von Datensätzen in das System einzuspeisen und zum anderen, wie diese Datensätze später abgerufen werden können. Ein Datenbanksystem wird erst dann für die Geschichtswissenschaft von Vorteil sein, wenn die Menge der darin enthaltenen Daten eine klassische Verarbeitung unmöglich macht und somit eine Arbeitserleichterung durch digitale Methoden klar ersichtlich wird. Im Falle der Personaldatenbank Mittelbau-Dora kann die erforderliche Menge an einzuspeisenden Daten nur erreicht werden, wenn verschiedene Personengruppen daran mitwirken, da es Daten zu tausenden von Personen zu integrieren gilt. Um dies in Zukunft realisieren zu können, sind die Eingabefelder übersichtlich und nach dem Vorbild der späteren Ausgabe strukturiert (siehe Abbildung 4). Da davon auszugehen ist, dass nicht alle in den Quellen vorhandenen Daten in das festgeschriebene Raster passen, wurde in jedem größeren Unterpunkt Raum für individuelle Bemerkungen gegeben. $\mathrm{Zu}$ beachten ist darüber hinaus auch, 
dass beim Umgang mit personenbezogenen Daten stets das geltende Datenschutzrecht eingehalten werden muss. Dies umso mehr, da sich nicht alle verfügbaren Daten außerhalb der gesetzlichen Sperrfristen bewegen. Es muss in der Konzeption daher genau festgeschrieben sein, welche potentiellen Nutzenden Zugang zu den verschiedenen Daten erhalten dürfen und welche nicht. Bereits bei der Eingabe der Datensätze muss somit die Möglichkeit gegeben sein, betroffene Bereiche für bestimmte Nutzergruppen zu sperren.
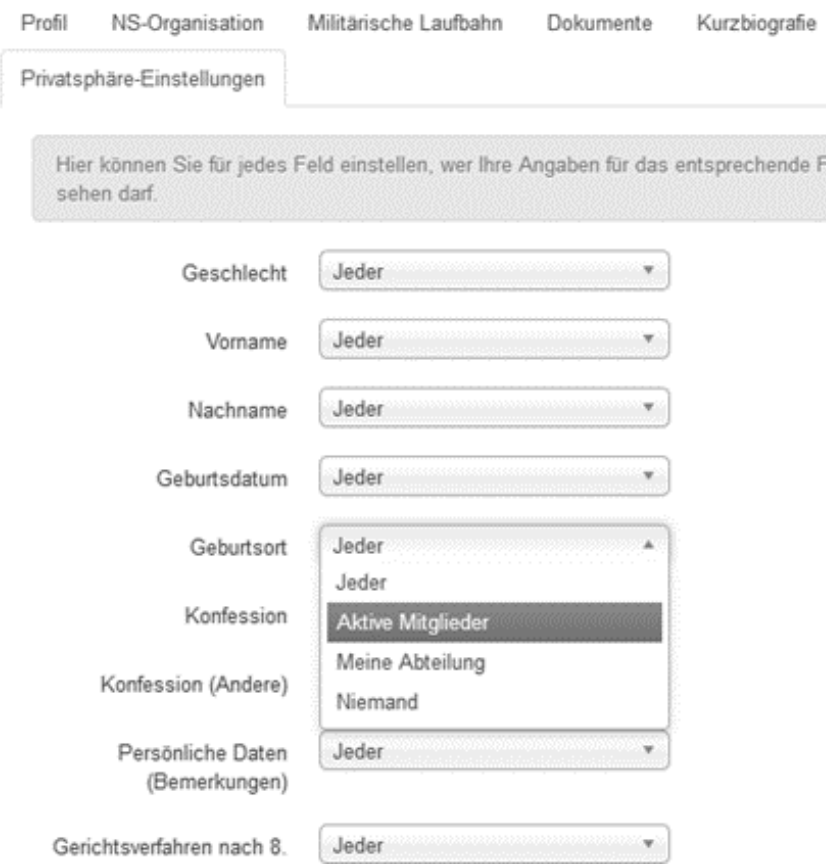

Abbildung 5: Suchmaske in der Datenbank.

Wie bereits beschrieben, ist neben der Eingabe von Daten auch die anschließende Suche innerhalb der Datenbank von besonderer Relevanz. Die integrierten Daten sind nur dann für den wissenschaftlichen Arbeitsprozess gewinnbringend nutzbar, wenn sie auch schnell und strukturiert gefiltert, gezielt an Fragestellungen angepasst gesucht sowie abgerufen werden können. Dem Eingangsbeispiel folgend, muss es dem Historiker C möglich sein, gezielt nach Angehörigen der Generation des Unbedingten zu suchen. Folglich reicht es nicht aus, nach einzelnen Geburtsjahren zu suchen, sondern das gezielte Filtern nach Alterskohorten sollte ermöglicht werden. Im Hinblick auf die Fragestellungen der Historikerin B zur Netzwerkforschung stellten sich klare Anforderungen an die möglichen Suchoptionen. Die Nutzerin muss durch das Da- 
tenbanksystem in die Lage versetzt werden, gezielt einzelne Lager und das zugehörige Personal auch hinsichtlich von Einsatzzeiträumen filtern zu können. Nur dann bietet die Datenbank eine sinnbringende Arbeitserleichterung. Möglichst viele der eingegebenen Daten sollten demnach separat abrufbar sein.

Auch bei der Personaldatenbank Mittelbau-Dora stellten die verschiedenen Suchoptionen und deren Verknüpfung mit potentiellen forschungsgeleiteten Fragestellungen einen weiteren zentralen Punkt innerhalb der konzeptionellen Überlegungen dar. Die verschiedenen Suchoptionen der Personaldatenbank zeichnen sich durch unterschiedliche Komplexität aus und ermöglichen so eine differenzierte Suche.

\begin{tabular}{|c|}
\hline Albrecht Bermhard 15.01.1915 \\
\hline Andritschek Adam 16.09.1898 \\
\hline Bachmeier Andreas o1 021900 \\
\hline Baer Richard 09.09.1911 \\
\hline Baganz Kail 06.09 .1925 \\
\hline Balg Johann 12.02 .1898 \\
\hline Ballstedt Paul 10.08.1902 \\
\hline Baver Johann 03.03:1898 \\
\hline Bauer Jakob 29.02 .1908 \\
\hline Baumavister Heinrich 31.01.1905 \\
\hline Baumann Johann 03.06.1903 \\
\hline Behrens Will 02.03 .1900 \\
\hline Beder Franz 16.08 .1899 \\
\hline Benlet Framz 16.081899 \\
\hline Bender Fnedrich 07, 11, 1899 \\
\hline Bender Peter 16.101899 \\
\hline
\end{tabular}

\section{Erweiterte Suche}

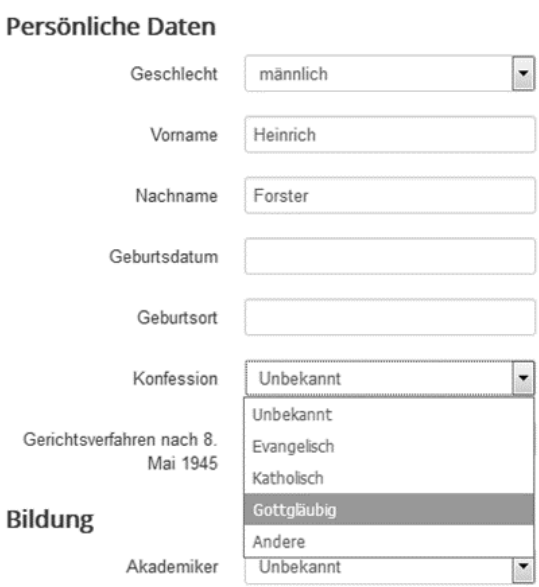

Abbildung 6-7: Listensuche und erweiterte Suche.

Die einfachste Suchoption ist dabei die Listensuche. Sie ermöglicht eine rein alphabetische Suche, in der alle Datensätze in alphabetischer Reihenfolge dem Nutzer präsentiert werden. Mittels Reitern wird der gewünschte Buchstabe ausgewählt und werden alle Personen, deren Nachname mit diesem Buchstaben beginnen, listenartig angezeigt.

Durch einen Klick auf die Person öffnet sich im nächsten Schritt der komplette Datensatz mit allen Inhalten. Diese Suchoption dient in erster Line einer vor allem überblicksartigen Suche.

Wird eine konkrete Person gesucht, stellt das System die Einfache Suche bereit. Abgefragt werden können: Name, Vorname, Geburtsdatum und Geburtsort. Mittels dieser Suche kann eine Person durch die abgefragten Parameter eindeutig identifiziert werden. Alle Suchergebnisse werden dem Nutzer nach 
Bestätigung der Suchparameter präsentiert. Existiert kein Eintrag zu einer Person mit diesen Suchparametern, erhält der Nutzer eine entsprechende Meldung durch das System. Diese weist auf mögliche Eingabefehler und Suchalternativen hin. Durch die Verankerung der Booleschen Operatoren (und/oder/exklusives oder) können Nutzer ihre Suchanfragen weiter präzisieren.

Die meisten Optionen bietet die Erweiterte Suche. Die Konzeption dieser Suchoption nimmt potentielle wissenschaftliche Fragestellungen in den Blick, um als adäquates Werkzeug für Historikerinnen und Historiker forschungsgeleitete Anfragen zu ermöglichen. Neben den einfachen personenbezogenen Angaben können vielfältige spezialisierte Suchparameter gewählt und miteinander kombiniert werden. Aufgrund der Anzahl der Suchparameter und den damit verbundenen wissenschaftlichen Fragestellungen können hier nur einige exemplarisch angeführt werden. So bietet das System beispielsweise die Möglichkeit bestimmte Alterskohorten zu suchen und diese mit möglichen Einsatzorten zu kombinieren. Im Hinblick auf wissenschaftliche Fragestellungen könnte so beispielsweise eine Suche nach Dienstgradgruppen erfolgen, wenn zu bestimmten Ebenen der militärischen Hierarchie geforscht wird. Die Erweiterte Suche bietet auch die Möglichkeit, Datensätze nach Eintrittsjahren in die NSDAP und SS zu staffeln. Welche Möglichkeiten große Datenmengen in Bezug auf die Mitgliedschaft in NS-Organisationen eröffnen, zeigen aktuelle Studien. ${ }^{13}$ Alle Suchparameter der Erweiterten Suche lassen sich daher untereinander kombinieren, um so spezifische Forschungsfragen aufgreifen zu können. Nach erfolgter Suche gibt das System die Treffer in Listenform aus. Die Treffer werden nach Nachnamen alphabetisch sortiert, angezeigt werden jedoch auch die Vornamen und die Geburtsdaten. Die Angabe des Geburtsdatums ist notwendig, um die Person eindeutig identifizieren zu können. Die ausgegebenen Profile können durch den Nutzer angeklickt werden, um Zugriff auf das Kernprofil zu erlangen.

13 Der Politikwissenschaftler Jürgen W. Falter stellte 2016 seine Ergebnisse zur Analyse der Parteimitglieder der NSDAP vor, die sich auf einen Fundus von circa 12 Millionen Karten der NSDAP-Mitgliedskartei stützen. Mittels einer groß angelegten Datenanalyse gelingt es Falter, die NSDAP und insbesondere deren Mitglieder aus verschiedenen Blickwinkeln zu beleuchten und neue Erkenntnisse zu liefern. Jürgen W. Falter: 10 Millionen ganz normale Parteigenossen. Neue Forschungsergebnisse zu den Mitgliedern der NSDAP 1925-1945, in: Abhandlungen der Geistes- und sozialwissenschaftlichen Klasse 4 (2016), S. 3-32. 


\section{Ausblick}

Sind alle konzeptionellen Überlegungen festgehalten, muss gerade im Rahmen von studentischen Projekten klar sein, dass die entstehende Datenbank einen Prototyp darstellt, der einer stetigen Weiterentwicklung und Förderung bedarf, um später unter Umständen in den regulären Wissenschaftsbetrieb überführt zu werden. Die Personaldatenbank für den Lagerkomplex Mittelbau-Dora befindet sich derzeit in einem Stadium, in dem alle beschriebenen Inhalte und Funktionen zwar größtenteils nutzbar sind, aber dennoch verschiedenste Probleme und Fragestellungen im Raum stehen, die es zukünftig noch zu lösen gilt. Beispielsweise ist es innerhalb des Datenbanksystems bereits heute möglich, an die Datensätze Dokumente als digitalisierte Scans anzuhängen und online zu speichern und abzurufen. Die Rechtefrage in Bezug auf Archivmaterial hingegen ist jedoch noch ungeklärt, sodass dieses Feature zum jetzigen Zeitpunkt lediglich im Testbetrieb zur Anwendung kommen kann. Auch eine Verlinkung von Dokumenten in Primärsystemen wäre zukünftig denkbar und sinnvoll.

Des Weiteren bieten Geoinformationssysteme eine Möglichkeit der Visualisierung, welche für eine solche Datenbank zentral wäre. Schichtel wies bereits in den 1990er Jahren darauf hin, dass die Hinwendung zur Öffentlichkeit als eine zentrale Aufgabe der Geschichtswissenschaft bezeichnet werden müsse. ${ }^{14}$ Hier liegt eine Stärke der Geoinformationssysteme. Durch deren Einsatz können komplexe raumbezogene Daten übersichtlich graphisch präsentiert werden. Komplexe Geoinformationssysteme erlauben darüber hinaus eine Analyse der eingegebenen Daten. Diese graphischen Präsentationen können die geschriebene Narration visualisierend ergänzen und so der Betrachtenden neue Blickwinkel auf die Geschichte bieten. Geschichtswissenschaftliche Erkenntnisse werden so auf eine neue Darstellungsebene gehoben. Hierbei können Geoinformationssysteme die geschriebene Narration keinesfalls gänzlich ersetzen, sondern dienen als helfendes Werkzeug, um komplexe Erkenntnisse übersichtlich zu ordnen und ansprechend darzustellen. Visualisierung als Präsentationsmöglichkeit muss zukünftig auch im Hinblick auf die Menge der Daten durch das System ermöglicht werden. Dies verdeutlicht, dass solche Projekte stets Raum für Erweiterungen lassen müssen und nicht als in sich abgeschlossene Konzeptionen verstanden werden dürfen.

Resümierend bedeutet dies: Will die Geschichtswissenschaft mit den rasanten Entwicklungen des digitalen Zeitalters Schritt halten, müssen die sich bietenden Potentiale erkannt, Werkzeuge zur digitalen Verarbeitung großer Datenmengen entwickelt und in den wissenschaftlichen Arbeitsprozess einge-

14 Dietmar Schenk, Horst Dieter Schichtel, Siegfried Quandt: Fachinformationssystem Geschichte. Historische Wissenschaft und öffentliche Kommunikation, Marburg 1992, S. 50. 
bunden werden. Nur so führt der Weg der Geschichtswissenschaft von Daten zu Erkenntnissen und die von Patel konstatierte Zeitenwende tritt ein.

\section{Literaturverzeichnis}

Jürgen W. Falter: 10 Millionen ganz normale Parteigenossen. Neue Forschungsergebnisse zu den Mitgliedern der NSDAP 1925-1945, in: Abhandlungen der Geistes- und sozialwissenschaftlichen Klasse 4 (2016), S. 3-32.

Holger Gast, Antonia Leugers, August Leugers-Scherzberg: Optimierung historischer Forschung durch Datenbanken. Die exemplarische Datenbank Missionsschulen 1887-1940, Bad Heilbrunn 2010.

Kai Grönke, Markus Kirchmann, Jörg Leyk: Big Data Auswirkungen auf Instrumente und Organisation der Unternehmenssteuerung, in: Ronald Gleich, Kai Grönke, Markus Kirchmann, Jörg Leyk (Hrsg.): Controlling und Big Data. Anforderungen, Auswirkungen, Lösungen, München 2014, S. 63-82.

Uwe Katzke: Spezifikation und Anwendung einer Modellierungssprache für die Automatisierungstechnik auf Basis der Unified Modeling Language UML (Dissertation), Kassel 2008.

Guido Koller: Geschichte digital. Historische Welten neu vermessen, Stuttgart 2016.

Kiran Klaus Patel: Zeitgeschichte im digitalen Zeitalter. Neue und alte Herausforderungen, in: Vierteljahrshefte für Zeitgeschichte 59 (2011), S. 331-352.

Dan Pilone: UML 2.0. kurz \& gut, 2. Auflage, Köln 2006.

Bernhard Rumpe: Modellierung mit UML. Sprache, Konzepte und Methodik, Berlin/Heidelberg/New York 2004.

Dietmar Schenk, Horst Dieter Schichtel, Siegfried Quandt: Fachinformationssystem Geschichte. Historische Wissenschaft und öffentliche Kommunikation, Marburg 1992, S. 50.

Edwin Schicker: Datenbanken und SQL. Eine praxisorientierte Einführung mit Anwendungen in Oracle, SQL Server und MySQL, 5. Auflage, Wiesbaden 2017.

Robert Sommer: Das KZ-Bordell. Sexuelle Zwangsarbeit in nationalsozialistischen Konzentrationslagern, 2. Auflage, Paderborn 2010.

Jens-Christian Wagner: Ellrich 1944/45. Konzentrationslager und Zwangsarbeit in einer deutschen Kleinstadt, Göttingen 2009.

Michael Wildt: Generation des Unbedingten. Das Führungskorps des Reichssicherheitshauptamtes, Hamburg 2002. 


\section{Historical Network Research and Semantic Graph Databases. The Case of a Network-Analytical Study on Wenceslaus IV and the Database Segrada}

\section{Introduction}

This article is based on an ongoing research project in which the authors are combining methods of Historical Network Research and Computer Sciences thereby furthering research in both disciplines. Thus, it is rather a report on a work in progress than the presentation of concluded research. After giving an introduction to the project's ideas and backgrounds we will focus on the advantages and challenges brought about when working in a collaborative project of the above named research fields.

The approach we are proposing intends to combine a case study on an historical elite network, conducted by Christian Oertel, with semantic graph database software, programmed by Maximilian Kalus. The network comprises of the people around King Wenceslaus IV (1378-1400/1419), who were - on a 'national' level - politically active in late medieval Germany and Bohemia during the time of his rule. The research history on Wenceslaus shows that he has always been depicted rather negatively. This has been done in the tradition of contemporary historiography's strongly biased picture of him. The study on his political network intends to shed new light on his ruling praxis and it is based on the contemporary charter material thereby attempting to give an account of his rule based on a different kind of sources than the usually used historiography. The semantic graph database approach is another research novelty. While aggregating knowledge by using a database is nothing new in historical research, this approach is innovative in its very flexible way of connecting knowledge. It enables scholars to aggregate and save knowledge during the process of research. The data gathered is broken down to more basic units that can be analyzed qualitatively and quantitatively, e.g. with network analysis or collective intelligence algorithms. 


\section{Historical Network Analysis}

The analysis of networks has gradually found its way into historical research during the last decades. Historians have been discussing along similar lines before these recent developments. Even though the term was invented later, prosopographies have been used at least since the early $20^{\text {th }}$ century. In 1979, Wolfgang Reinhard introduced the term "social interweavement" ("soziale Verflechtung") for such network structures. ${ }^{1}$ A more frequent occupation with networks within the historical profession can be observed during recent years. Potentials and constraints of network analysis in historical research have since been widely discussed. ${ }^{2}$ Although many publications use it rather on the terminological than on the methodological level, there are a number of studies in which the authors actually applied both the laborious method of the creation of databases as well as the software-based examination of a high number of actors and relations. ${ }^{3}$ Network analysis stems from relational sociological research where networks are described as structures which in many respects inhabit an

1 Wolfgang Reinhard: Freunde und Kreaturen. "Verflechtung" als Konzept zur Erforschung historischer Führungsgruppen. Römische Oligarchie um 1600, München 1979.

2 Christoph Boyer: Netzwerke und Geschichte. Netzwerktheorien und Geschichtswissenschaften, in: Berthold Unfried et al. (eds.): Transnationale Netzwerke im 20. Jahrhundert. Historische Erkundungen zu Ideen und Praktiken, Individuen und Organisationen, Leipzig 2008, pp. 47-58; Claire Lemercier: Formale Methoden der Netzwerkanalyse in den Geschichtswissenschaften. Warum und Wie?, in: Albert Müller, Wolfgang Neurath (eds.): Historische Netzwerkanalysen (=Österreichische Zeitschrift für Geschichtswissenschaften 23 (2012) 1), pp. 16-41; Eva Jullien: Netzwerkanalyse in der Mediävistik. Probleme und Perspektiven im Umgang mit mittelalterlichen Quellen, in: Vierteljahrschrift für Sozial- und Wirtschaftsgeschichte 100 (2013), pp. 135153; Maximilian Kalus: Historische Datenbanken und historisches Wissensmanagement, in: Jörn Kobes, Kai Ruffing, Wolfgang Spickermann (eds.): 20 Jahre Arbeitsgemeinschaft Geschichte und EDV, Gutenberg 2013, pp. 43-65; Kerstin Hitzbleck: Verflochten, vernetzt, verheddert? Überlegungen zu einem erfolgreichen Paradigma, in: Kerstin Hitzbleck, Klara Hübner (eds.): Die Grenzen des Netzwerks 1200-1600, Ostfildern 2014, pp. 17-40; Marten Düring, Linda von Keyserlingk: Netzwerkanalyse in den Geschichtswissenschaften. Historische Netzwerkanalyse als Methode für die Erforschung historischer Prozesse, in: Rainer Schützeichel, Stefan Jordan (eds.): Prozesse. Formen, Dynamiken, Erklärungen, Wiesbaden 2015, pp. 337-350; Marten Düring et al. (eds.): Handbuch Historische Netzwerkforschung. Grundlagen und Anwendungen, Münster 2016.

3 Mark Häberlein: Brüder, Freunde und Betrüger. Soziale Beziehungen, Normen und Konflikte in der Augsburger Kaufmannschaft um die Mitte des 16. Jahrhunderts, Berlin 1998; Mike Burkhardt: Der hansische Bergenhandel im Spätmittelater. Handel - Kaufleute - Netzwerke, Köln/Weimar/Wien 2009; Maximilian Kalus: Pfeffer - Kupfer - Nachrichten. Kaufmannsnetzwerke und Handelsstrukturen im europäisch-asiatischen Handel am Ende des 16. Jahrhunderts, Augsburg 2010; Götz-Rüdiger Tewes: Kampf um Florenz - Die Medici im Exil (1494-1512), Köln/Weimar/Wien 2011; Anna Collar: Religious Networks in the Roman Empire. The Spread of New Ideas, New York 2013; Robert Gramsch: Das Reich als Netzwerk der Fürsten. Politische Strukturen unter dem Doppelkönigtum Friedrichs II. und Heinrichs (VII.) 1225-1235, Ostfildern 2013. 
intermediate position between micro- and macrosociological structures, i.e. between single actors and large institutions or societies. ${ }^{4}$ This focus on relational structures results in a model of systems which are per se dynamic and flexible, particularly in contrast to models which center on institutions - even if the term 'institution' is interpreted very widely, e.g. 'the institution of kingship'. The focus of social network analysis relies less on the part of the actors of which the network consists. It rather focusses on the relations between those actors and particularly on the quality of those relations. Structural characteristics of the network are considered to have a great influence on the relations and interactions going on in the network. This approach is particularly valuable in historical research because it allows to include groups connected horizontally in the political hierarchy and to highlight their role in political decision processes and social interaction. The problem of applying sociological methods to medieval times, in which the abundance of modern sources cannot be found, has - to a large extend - been solved by the application of the balance theory of Fritz Heider which has been developed further by Dorwin Cartwright and Frank Harary. ${ }^{5}$ Yet, the research of medieval political structures has mostly analyzed its subjects following either a hierarchical top-down model or investigating the participation of very view high-ranking followers of a worldly or ecclesiastical leader. In the case study on Wenceslaus IV, the political systems of the Holy Roman Empire and of the kingdom of Bohemia are studied on the actor-level. These actors and their connections represent a network which is going to include several hundred actors and a lot more connections. Structurally, such complexity cannot be comprehended by the human mind. Therefore, the application of network analysis software is an absolute methodological necessity.

4 Norbert Elias: Was ist Soziologie?, München 1970; Johannes Weyer, Jörg Abel (eds.): Soziale Netzwerke. Konzepte und Methoden der sozialwissenschaftlichen Netzwerkforschung, München 2000; Roger Häußling: Zur Verankerung der Netzwerkforschung in einem methodologischen Relationalismus, in: Christian Stegebauer (ed.): Netzwerkanalyse und Netzwerktheorie. Ein neues Paradigma in den Sozialwissenschaften, Wiesbaden 2008, pp. 65-77.

5 Fritz Heider: The Psychology of Interpersonal Relations, New York 1958; Dorwin Cartwright, Frank Harary: Structural Balance. A Generalization of Heider's Theory, in: Samuel Leinhardt (ed.): Social Networks. A Developing Paradigm, New York 1977, pp. 9-25. 


\section{Semantic Graph Databases}

Semantic graphs have quietly entered many research fields in recent years. Based on graph theory, ${ }^{6}$ they have been combined with older research on knowledge theory like that of Marvin Minsky. ${ }^{7}$ At the same time databasebased research projects (and some platforms) have sprung into existence. There have been attempts to combine prosopography, databases, and network research, most often with existing tools like UCINET, Pajek, Gephi, histograph.io and others. ${ }^{8}$ What is still lacking is a comprehensive methodology for aggregating, keeping and analyzing historical data other than the network analysis discussed in the last paragraph. The question on how to work with historical data links to the wide field of knowledge management. Arguably, knowledge management is nothing new - humans have been doing it for thousands of years. In recent decades the digital revolution has vastly accelerated data aggregation and retrieval, creating new tools and concepts of what knowledge is and how it can be stored. The term 'semantic network' has been coined by the linguist M. Ross Quillian. ${ }^{9}$ In fact, systems applying these concepts have been implemented, like MultiNet by Herrmann Helbig. ${ }^{10}$ Likewise, the advent of the World Wide Web and its (proposed) progression into a Semantic Web has been inspired by such ideas. ${ }^{11}$ In theory, all knowledge can be represented in a huge graph, connecting knowledge nodes (representing 'entities' such as objects, beings, dates or ideas) semantically to each other. Such connections represent the interrelation between entities, such as friendship (in case of persons), validity (in case of time frames), or locality (in case of objects and locations). When looking at historical data, there are some further aspects to consider. There are various degrees of 'fuzziness' regarding data: Firstly, the names of entities can vary due to contemporary writing habits and historiographical tradition. Secondly, location and time data cannot be obtained clearly and consistently in every case. Thirdly, differing calendar systems have to be regarded. Some of these problems have been tackled by Johan van Benthem as well as Nachum Dershowitz and Edward M. Reingold, but many questions

6 Reinhard Diestel: Graph Theory, Heidelberg 2010; Mark Newman: Networks. An Introduction, 4. Auflage, Oxford 2010.

7 Marvin Minsky: A Framework for Representing Knowledge, in: Patrick H. Winston (ed.): The Psychology of Computer Vision, New York 1975, pp. 211-277.

8 See http://historicalnetworkresearch.org for examples.

9 M. Ross Quillian: Semantic Memory, in: Marvin Minsky (ed.): Semantic Information Processing, Cambridge (USA) 1968, pp. 227-270.

10 Herrmann Helbig: Knowledge Representation and the Semantics of Natural Language, Berlin 2006.

11 See Toby Segaran, Colin Evans, Jamie Taylor: Programming the Semantic Web, Sebastopol 2009. 
remain. ${ }^{12}$ Initially, a formal definition of historical semantic networks has been reached by Maximilian Kalus working on histcross, predecessor of Segrada (Semantic Graph-Database), a reference implementation of a historical semantic network database. ${ }^{13}$

The implementation of the software concept has been realized in two projects by Maximilian Kalus: Starting in 2005, he developed histcross, a web based application programmed in PHP. Its successor Segrada will be used in this project, a complete redesign of the original ideas. Segrada is a web application completely written in Java, making it far easier for users to get started. Moreover, the application learned from the experience of histcross, improving the user interface and utilizing current web technologies. The current version contains the following features: Data aggregation, including entities (vertices) and relations (edges), has been fully programmed. Moreover, this data can be annotated with instances and periods of time (possibly 'fuzzy' ones), geographic coordinates, tags, colors, and icons. Additionally, an ontology of tags can be created. Source references can be added to data. There is also a file upload function, making it possible to add images and text to the data. Documents added to the database can be indexed and searched in full text. The application includes a graph viewer for the network, various filters and search features, and internationalization is possible (localization currently in English and German). Finally, Segrada is a web application for any browser and can be run in a single user environment (desktop) or on a server (for team use). It can also scale out horizontally. Consequently, all important modern requirements have been implemented.

\section{Wenceslaus IV}

A great amount of research on the rulers of the house of Luxembourg is traditionally done on Charles IV, probably the most successful member of his dynasty. ${ }^{14}$ During the last decades Charles's second son Sigismund, German-

12 Johan van Benthem: The Logic of Time. A Model-Theoretic Investigation Into the Varieties of Temporal Ontology and Temporal Discourse, Dordrecht 1991; Nachum Dershowitz, Edward M. Reingold: Calendrical Calculations, 3. Auflage, Cambridge (USA), 2008.

13 Kalus: Pfeffer - Kupfer - Nachrichten.

14 See e.g. Eva Schlotheuber: Die Autobiographie Karls IV. und die mittelalterlichen Vorstellungen vom Menschen am Scheideweg, in: Historische Zeitschrift 281 (2005), pp. 561-591; Eva Schlotheuber: Der weise König. Herrschaftskonzeption und Vermittlungsstrategien Kaiser Karls IV. († 1378), in: T’Hémecht. Zeitschrift für Luxemburger Geschichte 63 (2011), pp. 265279; Ulrike Hohensee (ed.): Die Goldene Bulle. Politik - Wahrnehmung - Rezeption, Berlin 2009; Martin Bauch: Divina favente clemencia. Auserwählung, Frömmigkeit und Heilsvermitt- 
Roman emperor and king of Hungary and Bohemia, gained some attention as well. ${ }^{15}$ In contrast to this, very few medievalists have been conducting research on the rule of Sigismund's elder brother Wenceslaus IV during the last decades. Only three monographs concerning him or aspects of his rule have been published within the last fifty years by Ivan Hlaváček, Jiř́ Spevaček, and Eberhard Holtz. ${ }^{16}$ Ivan Hlaváček is the only researcher who has continually been publishing articles on different aspects of the rule of Wenceslaus. ${ }^{17}$ Medieval as well as modern historiography has drawn an almost completely negative picture of Wenceslaus and his rule. ${ }^{18}$ The most influential author of the $15^{\text {th }}$ century was Aeneas Silvius Piccolomini (later pope Pius II) whose negative assessment of this Luxembourg king has been adopted by modern German and Czech researchers like František Palacký, Theodor Lindner, František Bartoš, and Wilhelm Hanisch. ${ }^{19}$ First attempts to take a new look at some aspects of Wenceslaus's rule have been made in the last decade by Peter Moraw and Petra

lung in der Herrschaftspraxis Kaiser Karls IV., Köln/Weimar/Wien 2015; Erwin Frauenknecht, Peter Rückert (Bearb.): Kaiser Karl IV. (1316-1378) und die Goldene Bulle, Stuttgart 2016.

15 See e.g. Sabine Wefers: Das politische System Kaiser Sigismunds, Stuttgart 1989; Josef Macek, Ernö Marosi, Ferdinand Seibt (eds.): Sigismund von Luxemburg. Kaiser und König in Mitteleuropa 1387-1437. Beiträge zur Herrschaft Sigismunds und der europäischen Geschichte um 1400, Warendorf 1994; Jörg Hoensch: Kaiser Sigismund. Herrscher an der Schwelle zur Neuzeit, München 1996; Martin Kintzinger: Westbindungen im spätmittelalterlichen Europa. Auswärtige Politik zwischen dem Reich, Frankreich, Burgund und England in der Regierungszeit Kaiser Sigismunds, Stuttgart 2000; Michel Pauly, François Reiner (eds.): Sigismund von Luxemburg, Ein Kaiser in Europa, Mainz a. Rh. 2006; Karel Hrůza, Alexandra Kaar (eds.): Kaiser Sigismund (1368-1437). Zur Herrschaftspraxis eines europäischen Monarchen, Wien 2012.

16 Ivan Hlavácék: Das Urkunden- und Kanzleiwesen des böhmischen und römischen Königs Wenzel (IV.) 1376-1419, Stuttgart 1970; Jiří Speváček: Václav IV., 1361-1419. K předpokladùm husitské revoluce [Wenceslaus IV, 1361-1419. On the pre-history of the Hussite Revolution], Praha 1986; Eberhard Holtz: Reichsstädte und Zentralgewalt unter König Wenzel. 1376 - 1400, Warendorf 1993.

17 For some examples, see his articles collected in Mlada Holá, Martina Jeránková, Klára Woitschová (eds.): Ivan Hlaváček. Höfe, Residenzen, Itinerare, Prag 2011.

18 See Christian Oertel: Wenceslaus alter Nero. Die Darstellung Wenzels IV. in der Historiographie des späten 14. und 15. Jahrhunderts, in: Deutsches Archiv für Erforschung des Mittelalters 74 (2018) 2, pp. 673-702.

19 Aenea Silvio Piccolomini: Historia Bohemica, Joseph Hejnic, Hans Rothe (eds.): vol. 1, Köln/Weimar/Wien 2005; František Palacký: Böhmen unter König Wenzel IV., bis zum Ausbruch des Hussitenkrieges vom Jahre 1378-1419, Prag 1845; Theodor Lindner: Geschichte des Deutschen Reiches unter König Wenzel, 2 vols., Braunschweig 1875-1880; František Bartoš: Čechy v době Husově 1378-1415 [Bohemia During the Age of Hus 1378-1415], Prag 1947; Wilhelm Hanisch: König Wenzel von Böhmen (geb. 1361, gest. 1419). Studien zu seiner Regierung, I: Die Selbstdarstellung des Königtums in den Arengen der Urkunden König Wenzels, in: Ostbairische Grenzmarken. Passauer Jahrbuch für Geschichte, Kunst und Volkskunde 10 (1969), pp. 197-217; II: Seine Absetzung und die Absetzung König Richards II. von England, in: ibid. 11 (1970), pp. 5-32; III: Der König von Böhmen, in: ibid., pp. 33-61; IV: Seine Persönlichkeit. Versuch einer Beschreibung, in: ibid. 12 (1971), pp. 198-233. 
Roscheck. ${ }^{20}$ Very recently these new perspectives have been further pursued by Robert Novotný who seriously questioned the classification of the rule of Wenceslaus as favoritism and Klara Hübner who exposed the structures and mechanisms through which the negative picture of Wenceslaus has been constructed from the 1390s onwards. ${ }^{21}$ Taking up these latest research perspectives in the present project the question will be raised how monarchic rule was practically applied if Wenceslaus did not rely on favorites more than other kings of his age and if his ruling decisions were not only motivated by choleric attacks and depressive episodes as historiography has assumed until very recently. Because of the poor state of the edition of his charters, earlier research has mainly focused on historiography as a source basis. In the present project a fresh attempt is made to use the vast diplomatic material in order to complement the earlier view. People, institutions, places, and their relations are being collected and connected using Segrada to store and administer the data. The aim is to reconstruct the political network of Wenceslaus' age, to follow its development and to identify its (changing?) structure in order to gain new insights into the politics of the late $14^{\text {th }}$ century.

One of the themes, which dominate the historiography on Wenceslaus up to the present day, is the accusation of his being uninterested in politics, spending most of his time hunting and drinking. If this accusation should turn out to be correct, it would be interesting to see who actually did rule instead of the king. If it should turn out to be a mere historiographical construction, the interesting part would be to discover the personal networks through which Wenceslaus ruled his realm. Given the different political structures of the two kingdoms, it seems probable that he had to use different governing techniques. This would make it possible to compare the ways of ruling a kingdom and distinguish the

20 Petra Roscheck: König Wenzel IV. Opfer einer Schwarzen Legende und ihrer Strahlkraft, in: Peter Thorau, Sabine Penth, Rüdiger Fuchs (eds.): Regionen Europas - Europa der Regionen (FS Ulrich Jäschke), Köln/Weimar/Wien 2003, pp. 207-230; Peter Moraw: König Wenzels (1378-1419) Hof, eine Günstlingswirtschaft?, in: Jan Hirschbiegel, Werner Paravicini (eds.): Der Fall des Günstlings. Hofparteien in Europa vom 13. bis zum 17. Jahrhundert, Ostfildern 2004, pp. 163-175.

21 Robert Novotný: Ráj milců? Nižší šlechta na dvoře Václava IV. [The Paradies of Favourites? The Lower Gentry at the Court of Wenceslaus IV], in: Dana Dvořáčková-Malá (ed.): Dvory a rezidence ve středověku II [Courts and Residences in the Middle Ages II], Praha 2008, pp. 215229; Robert Novotný: Der niedere Adel um Wenzel IV. Ein Sonderfall?, in: Martin Bauch et al. (eds.): Heilige, Helden, Wüteriche. Herrschaftsstile der Luxemburger (1308-1437), Köln/ Weimar/Wien 2017, pp. 193-208; Klara Hübner: Mord und Rufmord. Politische Propaganda und die Anfänge der Schwarzen Legende König Wenzels IV., in: Andreas Bihrer, Dietmar Schiersner (eds.): Reformverlierer 1000-1800. Zum Umgang mit Niederlagen in der europäischen Vormoderne, Berlin 2016, pp. 57-95; Klara Hübner: Herrscher der Krise - die Krise des Herrschers. König Wenzel IV. als Projektionsfläche zeitgenössischer Propaganda, in: Bulletin der Polnischen Historischen Kommission 11 (2016), pp. 294-320. 
factors which made his more than forty year reign (1378-1419) comparatively successful in Bohemia while it failed in Germany were Wenceslaus was disposed in 1400 .

\section{Methodological and Theoretical Approach}

As stated above, both methods of graph and knowledge theory are to be combined into a historical semantic network. Graphs are mathematical constructs describing sets of objects, some of which are connected with each other. ${ }^{22}$ Since they are mathematical representations, a number of graph operations can be operationalized on them. Graphs are the basis of social networks used in sociology and other academic disciplines. In most cases, social networks are created by abstracted mass data. Objects in the graph represent persons or groups, links between these vertices describe an abstract relation or class of relations. Social networks work best on sets of data in which the quality of the relations has been standardized in one way or another. In Facebook, for example, people are either friends or not. There is no category for casual acquaintances.

Another way to model knowledge is the object oriented one. Objectorientation is a programming paradigm that treats all data as objects. ${ }^{23}$ Objects can represent almost anything including persons and relations. In most programming environments, objects are created from classes which serve as templates. Classes are blueprints which define the characteristics (or attributes) and behavior (or methods) of actual objects based on them. For example, a class 'person' could define 'first name', 'surname', 'date of birth', 'date of death', and 'list of friends' as attributes. A typical method might be befriended which would add another person to the list of friends. More accurately, a reference to this person would be created. This makes it possible to represent social networks in a similar way to the one described above. However, unlike simple social network graphs, objects can carry additional data. Moreover, relations between network nodes can be annotated with additional data, since they can be objects, too. Actual knowledge can be stored and created in this way. In fact, object oriented approaches touch much of Marvin Minsky's frame theory created in 1975.

Semantic networks trace their roots back to all these theories. On a formal level, such networks are defined to be labeled multidigraphs. This means that edges of the graph are directed and multiple edges between which the same vertices are allowed. Moreover, both vertices and edges are labeled and en-

22 See Diestel: Graph Theory for a formal introduction in graphs.

23 See Martín Abadi, Luca Cardelli: A Theory of Objects, New York 1996. 
riched with annotations. These annotations include alternative names, descriptive text(s), instants or intervals of time, geographic references, typification and/or tags, links to sources and to external information (such as entries in bibliographic databases, ontological types, etc.). Consequently, the semantic network can use metrics developed within graph and network theory such as centrality, density, clustering/clique analysis, measuring homophily, propinquity, closures, and similar elements. Moreover, adding weights to the edges (simulating strength of social ties or geographic distance, for example) will enable the correlation of data within the network more thoroughly. In addition, methods akin to artificial intelligence can be applied to the data to analyze it. One planned feature of Segrada is to implement similarity patterns based on data entered already. This would make it possible to suggest additional new connections after creating new ones, e.g. additional relationships of two or more persons (artificial reasoning based on a learning system implemented via neural networks).

However, a semantic network database is not only a tool for evaluating data. It also facilitates aggregating this data in the first place. Researchers have to disassemble quantitatively complex data into more basic units, which are faster to grasp. Regesta, i.e. summaries of charters, are an example for such a simplification, semantic networks go beyond this by making it possible to actually interrelate data while aggregating it. This speeds up research and makes it easy to continuously add to the database and to dispatch new inquiries onto the same data later on.

\section{Advantages and Challenges of Combining the Methods}

There are three hermeneutical steps in which research in the area of softwarebased analysis of historical personal networks have to be conducted. The first step could be called 'text digging' and is genuine qualitative historical research. Sources are critically (and manually) analyzed and the results are entered into the database. Accordingly, this first step is critical for the quality and the reliability of the overall data. Source analysis has to be carried out by an expert historian in tedious hermeneutical work. The resulting database can - in a second step - be worked with, using network analysis methods and software, e.g. block model analysis and exponential random graph models (ERGM), to automatically create graphs, matrices, and other secondary data to continue research with. Consequently, results allow the researcher to view and understand the network structure which can, for example, include closely interconnected parts of the network (clusters) or structurally important actors (dealers) 
connecting these. For this analysis, additional tools like Gephi or Pajek will be used. Segrada is able to export to these formats, as well as to work with graphs, too. It will be able to create subsets of graphs, for example, that can be exported to an external application or show a detail of a larger network. The third and last step consists of the qualitative evaluation of the results. This step has, again, to be carried out by a professional historian who has to cautiously interpret these, assess their credibility, and re-integrate them into the historical setting.

The collaboration of the two approaches is generating a significant surplus as there is intensive communication between the two project parts on a practical, methodological, and theoretical level. On the one hand, a continuous flow of feedback provides the programmer of the database software with valuable information about the practicability of the different features of Segrada when applied to concrete historical problems. On the other hand, this flow of information gives the historian the rare opportunity to influence the design of the software he is using and have it adjusted to his (and the future user's) advantage. The application of the semantic graph database also enables methodological innovation in Historical Network Research since new ways of connecting the collected data are provided by the new database system as described above. While most network approaches flatten interconnections between actors to a few relational types, semantic database approaches allow the inclusion of many connection types as well as the possibility to weigh these connections regarding their relevance or credibility. Consequently, less information is lost due to a lower level of abstraction in comparison with network analysis data handling. This is an essential methodological improvement compared to present research.

One of the core questions for historians is how data is actually handled and how much one can trust it. One of the human mind's psychological shortcomings is called 'confirmation bias', the tendency to interpret data to support one's world view. ${ }^{24}$ The one-sided research situation concerning Wenceslaus IV summarized above could be called such a 'confirmation bias' passed on through generations of medievalists. In order not to fall into the same trap and simply try to rehabilitate Wenceslaus by reversing the argumentation and to make him a 'great' and successful king, the unprejudiced data-handling of the software can serve as corrective. The example of Wenceslaus IV is thus a perfect testing ground to exemplify the advantages of semantic networking meth-

24 See Peter Wason: On the Failure to eliminate Hypotheses in a Conceptual Task, in: Quarterly Journal of Experimental Psychology 12 (1960) 3, pp. 129-140 and the critique by Joshua Klayman, Ha Young-Won: Confirmation, Disconfirmation and Information in Hypothesis Testing, in: Psychological Review (American Psychological Association) 94 (1987) 2, pp. 211-228. 
ods in historical research. In this respect, one attribute of complex networks is useful, too: In classical historical research it is always possible to adjust the interpretation of given data to the intentions of the researcher or to neglect evidence which does not fit into the narrative the researcher wants to relate. Such practices can, of course, not be ruled out when interpreting the data produced by network analysis software. However, at least at the stage of the collection of data, when entering the data of a single dyad (i.e. two actors and their relation) into the database, the significance of the connotation of this dyad for the whole network can hardly be anticipated by the researcher due to the network's complex structure. Because of this limited possibility of anticipation software-based network research runs a smaller risk of (consciously or unconsciously) interpreting evidence in a particular direction during the stage of data aggregation.

Not only the human mind but also software has its shortcomings when it comes to data handling. While a researcher will interpret data as man-made cultural product software will take it at face value without further interpretation at first. It is the researcher's obligation to use his or her skills to feed data into the database in a reliable and consistent way. In the case of network research, the challenge lies in the classification of relations and their weight. In reality, relations between humans are many-shaded and complex. This complexity has to be reduced and classified in an abstract way within the database. In many network approaches, such relations are flattened to base types, such as 'friendly' vs. 'hostile'. Much of the original complexity - and thus important data - is lost. The present project cannot outdo this shortcoming of software, but it can lessen its effects. Firstly, due to the relational nature of the database, the researcher can add an infinite number of relation types that can in turn be hierarchically classified. Moreover, a weight factor can be added to define the reliability and/or strength of the relation between two nodes. Both elements enable more precise qualitative data aggregation while still not losing the ability to quantify the information collected.

These two sides of the 'data handling problem' are two among a number of theoretical issues which have to be practically solved and which are and will further be discussed and reflected upon on a theoretical level during the course of the project. Other such issues could be: How can dynamic changes are adequately represented? Every network has to approach the question of how to present changes within the graph over a given period of time. Instances of time are relatively simple to represent, as are periods. Such instances or periods can be attached to network entities (nodes and edges) and a network view can also be restricted to show a certain point in time or a specific period. Gradual, nondiscrete changes (e.g. the geographic spread of the Black Plague in the mid-14 ${ }^{\text {th }}$ 
century) are more complex and to find ways to depict such changes will be among the aims of the project. A similar challenge exists with geographic data: On an abstract level, geographic data can be represented as points, lines, and polygons. A database has to be able to cope with all three elements to work properly with geographic data. To make matters even more complex, geographic data can also be subject to changes over time, for example, when rivers change their course or when administrational units change their scope or are dissolved. As a consequence, geographic data has to cope with chronological instances and periods in some way, too. Connected with this problem is 'fuzzy data'. A particular problem of pre-modern (and even modern) historical research is that records are often non-specific, contradictory or outright erroneous. Computers on the other hand work best with crystal clear data and do not perform very well with fuzzy data.

All these issues, the many-shaded nature of human relations versus the necessary classification within database software, gradual developments which have to be broken down into a series of instances to become softwaremanageable as well as 'fuzzy data' can be viewed as different aspects of the general discrepancy between how the human mind perceives the world (gradual and relational) and how a computer needs its data to be structured (in pieces). The aim of a project combining both approaches could thus be to contribute on a practical as well as on a theoretical level to the solution or at least to a reconciliation of this discrepancy. For example, if one takes the representation of chronological developments within graphs: One possibility is to utilize 'time slices'. The smaller the time slices are, the more accurate changes can be simulated. But however small these slices are, there will still be a discrete 'jump' within the data when looking at two instances of time. Therefore, a possibility has to be found to model gradual changes within the network. Promising first results have been reached using moving objects databases (used in fleet management and meteorology), but these results are yet to be included in software visualizing network graphs. Recent developments look very promising. One research question would thus be to integrate such methods into historical network research and expand on them accordingly.

Another open research problem is the loss of information particularly at two stages during data aggregation and procession. Firstly, when aggregating data within a network representation, it must necessarily be abstracted. Consequently, some information is invariably lost. For pure network analysis, this might be acceptable. For later data retrieval and reuse, this might pose a problem. The second stage at which data is invariably lost is the point at which complex networks have to be simplified and included into the narrative structure of a research report. In order to reduce the data loss in this process of 
translation from the complex network structure into a stringent narrative, an important question could be if there are more appropriate forms through which networks can be linguistically narrated and which can reproduce the complexity of networks more adequately than a common stringent narration.

To some of the above questions solutions on the technical level have been developed by Maximilian Kalus. He has implemented and is planning to implement further features to handle fuzziness in Segrada. This includes earmarking fuzzy data and using fuzzy weight mechanisms (derived from fuzzy logic). One of the challenges will be to determine how to set fuzzy weights properly to make data dependable. The semantic nature of the database makes it easier to avoid data loss during text mining since a semantic model is relatively flexible to change if the need arises. A historian might decide to combine certain types of relations or to create new ones. The database will enable to do this in a comparatively easy way. Methodologically, this will make it possible to retain much of the narratively interesting features of the original data, which will strengthen the data for future use. Still, it is the researcher's responsibility to ensure the input of reliable data. The software will support the collection of reliable data, but it will try not to restrict it too much.

\section{References}

Martín Abadi, Luca Cardelli: A Theory of Objects, New York 1996.

František Bartoš: Čechy v době Husově 1378-1415 [Bohemia During the Age of Hus 13781415], Prag 1947.

Martin Bauch: Divina favente clemencia. Auserwählung, Frömmigkeit und Heilsvermittlung in der Herrschaftspraxis Kaiser Karls IV., Köln/Weimar/Wien 2015.

Christoph Boyer: Netzwerke und Geschichte. Netzwerktheorien und Geschichtswissenschaften, in: Berthold Unfried, Jürgen Mittag, Marcel van der Linden, Eva Himmelstoss (eds.): Transnationale Netzwerke im 20. Jahrhundert. Historische Erkundungen zu Ideen und Praktiken, Individuen und Organisationen, Leipzig 2008, pp. 47-58.

Mike Burkhardt: Der hansische Bergenhandel im Spätmittelater. Handel - Kaufleute Netzwerke, Köln/Weimar/Wien 2009.

Dorwin Cartwright, Frank Harary: Structural Balance. A Generalization of Heider's Theory, in: Samuel Leinhardt (ed.): Social Networks. A Developing Paradigm, New York 1977, pp. 9-25.

Anna Collar: Religious Networks in the Roman Empire. The Spread of New Ideas, New York 2013.

Reinhard Diestel: Graph Theory, 4. Auflage, Heidelberg 2010.

Nachum Dershowitz, Edward M. Reingold: Calendrical Calculations, 3. Auflage, Cambridge (USA) 2008.

Marten Düring, Linda von Keyserlingk: Netzwerkanalyse in den Geschichtswissenschaften. Historische Netzwerkanalyse als Methode für die Erforschung historischer Prozesse, in: 
Rainer Schützeichel, Stefan Jordan (ed.): Prozesse. Formen, Dynamiken, Erklärungen, Wiesbaden 2015, pp. 337-350.

Marten Düring et al. (eds.): Handbuch Historische Netzwerkforschung. Grundlagen und Anwendungen, Münster 2016.

Norbert Elias: Was ist Soziologie?, München 1970.

Erwin Frauenknecht, Peter Rückert (Bearb.): Kaiser Karl IV. (1316-1378) und die Goldene Bulle, Stuttgart 2016.

Robert Gramsch: Das Reich als Netzwerk der Fürsten. Politische Strukturen unter dem Doppelkönigtum Friedrichs II. und Heinrichs (VII.) 1225-1235, Ostfildern 2013.

Mark Häberlein: Brüder, Freunde und Betrüger. Soziale Beziehungen, Normen und Konflikte in der Augsburger Kaufmannschaft um die Mitte des 16. Jahrhunderts, Berlin 1998.

Wilhelm Hanisch: König Wenzel von Böhmen (geb. 1361, gest. 1419). Studien zu seiner Regierung, I: Die Selbstdarstellung des Königtums in den Arengen der Urkunden König Wenzels, in: Ostbairische Grenzmarken. Passauer Jahrbuch für Geschichte, Kunst und Volkskunde 10 (1969), pp. 197-217; II: Seine Absetzung und die Absetzung König Richards II. von England, in: ibid. 11 (1970), pp. 5-32; III: Der König von Böhmen, in: ibid., pp. 33-61; IV: Seine Persönlichkeit. Versuch einer Beschreibung, in: ibid. 12 (1971), pp. 198-233.

Roger Häußling: Zur Verankerung der Netzwerkforschung in einem methodologischen Relationalismus, in: Christian Stegebauer (ed.): Netzwerkanalyse und Netzwerktheorie. Ein neues Paradigma in den Sozialwissenschaften, Wiesbaden 2008, pp. 65-77.

Fritz Heider: The Psychology of Interpersonal Relations, New York 1958.

Herrmann Helbig: Knowledge Representation and the Semantics of Natural Language, Berlin 2006.

Kerstin Hitzbleck: Verflochten, vernetzt, verheddert? Überlegungen zu einem erfolgreichen Paradigma, in: Kerstin Hitzbleck, Klara Hübner (eds.): Die Grenzen des Netzwerks 12001600, Ostfildern 2014, pp. 17-40.

Ivan Hlaváček : Das Urkunden- und Kanzleiwesen des böhmischen und römischen Königs Wenzel (IV.) 1376-1419, Stuttgart 1970.

Jörg Hoensch: Kaiser Sigismund. Herrscher an der Schwelle zur Neuzeit, München 1996.

Ulrike Hohensee (ed.): Die Goldene Bulle. Politik - Wahrnehmung - Rezeption, Berlin 2009.

Mlada Holá , Martina Jeránková, Klára Woitschová (eds.): Ivan Hlaváček. Höfe, Residenzen, Itinerare, Prag 2011.

Eberhard Holtz: Reichsstädte und Zentralgewalt unter König Wenzel. 1376-1400, Warendorf 1993.

Karel Hrůza, Alexandra Kaar (eds.): Kaiser Sigismund (1368-1437). Zur Herrschaftspraxis eines europäischen Monarchen, Wien 2012.

Klara Hübner: Mord und Rufmord. Politische Propaganda und die Anfänge der Schwarzen Legende König Wenzels IV., in: Andreas Bihrer, Dietmar Schiersner (eds.): Reformverlierer 1000-1800. Zum Umgang mit Niederlagen in der europäischen Vormoderne, Berlin 2016, pp. 57-95.

Klara Hübner: Herrscher der Krise - die Krise des Herrschers. König Wenzel IV. als Projektionsfläche zeitgenössischer Propaganda, in: Bulletin der Polnischen Historischen Kommission 11 (2016), pp. 294-320. 
Eva Jullien: Netzwerkanalyse in der Mediävistik. Probleme und Perspektiven im Umgang mit mittelalterlichen Quellen, in: Vierteljahrschrift für Sozial- und Wirtschaftsgeschichte 100 (2013), pp. 135-153.

Maximilian Kalus: Historische Datenbanken und historisches Wissensmanagement, in: Jörn Kobes, Kai Ruffing, Wolfgang Spickermann (eds.): 20 Jahre Arbeitsgemeinschaft Geschichte und EDV, Gutenberg 2013, pp. 43-65.

Maximilian Kalus: Pfeffer - Kupfer - Nachrichten. Kaufmannsnetzwerke und Handelsstrukturen im europäisch-asiatischen Handel am Ende des 16. Jahrhunderts, Augsburg 2010.

Martin Kintzinger: Westbindungen im spätmittelalterlichen Europa. Auswärtige Politik zwischen dem Reich, Frankreich, Burgund und England in der Regierungszeit Kaiser Sigismunds, Stuttgart 2000.

Joshua Klayman, Ha Young-Won: Confirmation, Disconfirmation and Information in Hypothesis Testing, in: Psychological Review (American Psychological Association) 94:2 (1987), pp. 211-228.

Claire Lemercier: Formale Methoden der Netzwerkanalyse in den Geschichtswissenschaften. Warum und Wie?, in: Albert Müller, Wolfgang Neurath (eds.): Historische Netzwerkanalysen (=Österreichische Zeitschrift für Geschichtswissenschaften 23:1 (2012)), pp. 16-41.

Theodor Lindner: Geschichte des Deutschen Reiches unter König Wenzel, 2 vols., Braunschweig 1875-1880.

Josef Macek, Ernö Marosi, Ferdinand Seibt (eds.): Sigismund von Luxemburg. Kaiser und König in Mitteleuropa 1387-1437. Beiträge zur Herrschaft Sigismunds und der europäischen Geschichte um 1400, Warendorf 1994.

Marvin Minsky: A Framework for Representing Knowledge, in: Patrick H. Winston (ed.): The Psychology of Computer Vision, New York 1975, pp. 211-277.

Peter Moraw: König Wenzels (1378-1419) Hof, eine Günstlingswirtschaft?, in: Jan Hirschbiegel, Werner Paravicini (eds.): Der Fall des Günstlings. Hofparteien in Europa vom 13. bis zum 17. Jahrhundert, Ostfildern 2004, pp. 163-175.

Mark Newman: Networks. An Introduction, Oxford 2010.

Robert Novotný: Ráj milců? Nižši šlechta na dvoře Václava IV. [The Paradies of Favourites? The Lower Gentry at the Court of Wenceslaus IV], in: Dana Dvořáčková-Malá (ed.): Dvory a rezidence ve středověku II [Courts and Residences in the Middle Ages II], Praha 2008, pp. 215-229.

Robert Novotný: Der niedere Adel um Wenzel IV. Ein Sonderfall?, in: Martin Bauch et al. (eds.): Heilige, Helden, Wüteriche. Herrschaftsstile der Luxemburger (1308-1437), Köln/Weimar/Wien 2017, pp. 193-208.

Christian Oertel, Wenceslaus alter Nero. Die Darstellung Wenzels IV. in der Historiographie des späten 14. und 15. Jahrhunderts, in: Deutsches Archiv für Erforschung des Mittelalters 74:2 (2018), pp. 673-702.

František Palacký: Böhmen unter König Wenzel IV. bis zum Ausbruch des Hussitenkrieges vom Jahre 1378-1419, Prag 1845.

Michel Pauly, François Reiner (eds.): Sigismund von Luxemburg, Ein Kaiser in Europa, Mainz a. Rh. 2006.

Aenea Silvio Piccolomini: Historia Bohemica, Joseph Hejnic, Hans Rothe (eds.): vol. 1, Köln/ Weimar/Wien 2005. 
M. Ross Quillian: Semantic Memory, in: Marvin Minsky (ed.): Semantic Information Processing, Cambridge (USA) 1968, pp. 227-270.

Wolfgang Reinhard: Freunde und Kreaturen. "Verflechtung" als Konzept zur Erforschung historischer Führungsgruppen. Römische Oligarchie um 1600, München 1979.

Petra Roschek: König Wenzel IV. Opfer einer Schwarzen Legende und ihrer Strahlkraft, in: Peter Thorau, Sabine Penth, Rüdiger Fuchs (eds.): Regionen Europas - Europa der Regionen (FS Ulrich Jäschke), Köln/Weimar/Wien 2003, pp. 207-230.

Götz-Rüdiger Tewes: Kampf um Florenz - Die Medici im Exil (1494-1512), Köln/Weimar/ Wien 2011.

Eva Schlotheuber: Die Autobiographie Karls IV. und die mittelalterlichen Vorstellungen vom Menschen am Scheideweg, in: Historische Zeitschrift 281 (2005), pp. 561-591.

Eva Schlotheuber: Der weise König. Herrschaftskonzeption und Vermittlungsstrategien Kaiser Karls IV. († 1378), in: T’Hémecht. Zeitschrift für Luxemburger Geschichte 63 (2011), pp. 265-279.

Toby Segaran, Colin Evans und Jamie Taylor: Programming the Semantic Web, Sebastopol 2009.

Jiří Speváček: Václav IV., 1361-1419. K předpokladùm husitské revoluce [Wenceslaus IV, 1361-1419. On the pre-history of the Hussite Revolution], Praha 1986.

Peter Wason: On the Failure to eliminate Hypotheses in a Conceptual Task, in: Quarterly Journal of Experimental Psychology 12:3 (1960), pp. 129-140.

Sabine Wefers: Das politische System Kaiser Sigismunds, Stuttgart 1989.

Johannes Weyer, Jörg Abel (eds.): Soziale Netzwerke. Konzepte und Methoden der sozialwissenschaftlichen Netzwerkforschung, München 2000.

Johan van Benthem: The Logic of Time. A Model-Theoretic Investigation Into the Varieties of Temporal Ontology and Temporal Discourse, Dordrecht 1991. 


\section{Marlene Ernst}

\section{Salzburg zu Tisch. Wie Citizen Scientists helfen, die barocke Küche zu ergründen}

\section{Einleitung}

Die Ernährungsgeschichte (nicht nur wie im vorliegenden Fall von Salzburg, sondern auch allgemein) hat eine große öffentliche Anziehungskraft. Zu diesem Schluss sind wir am Zentrum für Gastrosophie am Fachbereich Geschichte der Universität Salzburg über die Jahre durch zahlreiche Workshops, Präsentationen sowie Events gekommen. Dieses allgemeine Interesse zu bündeln und in eine aktive Mitarbeit in einem wissenschaftlichen Vorhaben umzuwandeln, war die Herausforderung bei der Konzeption und Durchführung des Citizen-Science-Projekts Salzburg zu Tisch. Wie aus Bürgerinnen und Bürgern Citizen Scientists wurden und wie sich die Zusammenarbeit gestaltet, wird auf den folgenden Seiten beschrieben.

\section{Salzburg zu Tisch: Ein Projekt stellt sich vor}

„Item auß Piern Postetten zumachen, / schelß vnnd schneits zu .4. taillen, vnd brens / in ainen schmalz, legs in die Postedten, Nimb / Khanußln vnnd lints gewürz, Imber, Pfeffer, / etlich ganze Nägelein, nimb ain Wennig buter. /“ (Rezept aus dem Dückher Kochbuch von 1654) ${ }^{1}$

Dieses Birnentarte-Rezept, das in einer Handschrift aus dem Nachlass einer Salzburger Adelsfamilie stammt, soll nur einen kleinen Einblick in die Sprach-

1 Salzburger Landesarchiv (SLA), Dückher Nachlass Karton 1/4, Bl. 56r. Das Rezept in modernem Deutsch: „So aus Birnen eine Pastete zu machen. Schäle und schneide sie in vier Teile und frittiere sie in Schmalz. Lege sie in die Pasteten [wie der Teig dafür zubereitet werden soll, wird nicht angeführt; es würde sich allerdings ein Mürbeteig anbieten]. Nimm Kornelkirschen und ein mildes Gewürz, Ingwer, Pfeffer, einige ganze Nelken. Nimm ein wenig Butter." Wie in barocken Rezepten üblich, werden keine genauen Angaben zu Mengenverhältnissen angegeben bzw. Details zur Zubereitung der Erfahrung der Köchin oder des Kochs überlassen. 
welt bzw. Thematik der barocken Küche bieten. Was aß und trank man in der Frühen Neuzeit - und warum? Das ist eine der fundamentalen Fragestellungen, mit denen sich die gastrosophische Forschung der Universität Salzburg auseinandersetzt. Am Zentrum für Gastrosophie des Fachbereichs Geschichte beschäftigen sich die Mitarbeiterinnen und Mitarbeiter bereits seit der Gründung 2008 mit Themen rund um die Ernährungsgeschichte. Im vom Fonds zur Förderung der wissenschaftlichen Forschung (FWF) geförderten und auf drei Jahre angelegten Projekt „P 28447-G28: Regionale Tradition und Kulturtransfer in der Ernährung. Das Beispiel der Residenzstadt Salzburg 1500-1800“ wurde von 2016 bis 2019 im Speziellen die barocke Esskultur verschiedener sozialer Schichten in der Stadt Salzburg anhand der Bereiche erzbischöflicher Hof, Bürgertum, Gastronomie, Klöster sowie geschlossene Häuser erforscht. Es handelt sich dabei um eine Fallstudie zu den Funktionen und kulturellen Praktiken des Essens und Trinkens in einer fürst-erzbischöflichen Stadt der Frühen Neuzeit. Es basiert auf einem Mehrebenen-Modell, das um materielle und verschiedene symbolische Qualitäten von Ernährung weiß, ohne sie in eine Hierarchie von niederen (materiellen) und höheren (kulturellen) Gebieten einzuordnen. Vielmehr werden alle Qualitäten als miteinander verbunden angenommen. Durch die Anwendung dieses Ansatzes auf einen überschaubaren geographischen Raum und durch exzellentes, weitreichendes Quellenmaterial wird eine innovative und komplexe Analyse ermöglicht. Ziel der Studie ist es, Ernährung durch genaue Analyse von Kontexten und Verflechtungen als bedeutenden und integralen Bestandteil von Kultur, Gesellschaft und Wirtschaft darzustellen.

Das dazugehörige Top-Citizen-Science-Erweiterungsprojekt „TCS 37: Salzburg zu Tisch“ ${ }^{2}$ mit zweijähriger Laufzeit verbindet diese Thematik nun mit der Citizen-Science-Methode, bei der Laien in die Forschung mit eingebunden werden, und erschließt zusammen mit Freiwilligen aus der Bevölkerung relevante Quellen der Kochbuchliteratur. Das Hauptziel dieses bürgerwissenschaftlichen Ansatzes ist es, einen detaillierteren und umfassenderen Einblick in die barocke Küche der Stadt Salzburg, u. a. durch zusätzliche Vergleichsdaten, zu gewinnen. Mittlerweile hat die Anzahl der geisteswissenschaftlichen Citizen-Science-Projekte - insbesondere aus dem Transkriptions- und Sammelbereich, wie etwa das Genealogische Postkartenarchiv ${ }^{3}$ oder die Topothek ${ }^{4}$, aber auch mit spielerischem Ansatz wie in dem kunsthistorischen Projekt

2 Weitere Details zum Projekt können der Homepage des Zentrums für Gastrosophie entnommen werden: https://bit.ly/2FGcLsr.

3 Vgl. http://www.genpas.de/ (letzter Zugriff: 30.11.2019.

4 Vgl. https://www.topothek.at/de/ (letzter Zugriff: 30.11.2019). 
Artigo $^{5}$ - stark zugenommen. Doch hauptsächlich bedient sich die naturwissenschaftliche Forschung, dabei vor allem aus dem Biodiversitätssektor, dieser Methode. $^{6}$

Historisch interessierte Menschen, die sich zusätzlich auch noch gerne mit ernährungsrelevanten Themen bzw. dem Kochen beschäftigen, findet man glücklicherweise recht rasch. Im vorliegenden Fall genügte, trotz zahlreicher im Vorfeld angedachter Kommunikationsstrategien, die von NewsletterAussendungen (über den ca. 2.000 Personen umfassenden Verteiler) bis hin zu Beiträgen in sozialen Medien (vor allem über den Facebook-Account der Gastrosophie) und auf Food \& Lifestyle-Blogs reichten, bereits ein einziger Aufruf in einem Artikel in den Salzburger Nachrichten. ${ }^{7}$ So konnte innerhalb weniger Tage die vorgesehene Gruppe von 30 Freiwilligen gefunden werden, die in Einführungsworkshops die Details zum Projekt inkl. Zeitplan sowie eine Einschulung in die Transkriptionsarbeit bekommen haben. Mit dem Start der tatsächlichen Transkriptionsarbeit stellte sich für manche von ihnen heraus, dass die Vorstellungen zur Mitarbeit von dem, was tatsächlich gefragt sowie gefordert wird, doch stark abwich und so haben sich zwei, drei Personen seit den Einführungsworkshops nicht mehr gemeldet. Derlei Ausfälle waren jedoch unvermeidbar und es melden sich weiterhin immer wieder neue Interessierte, die gerne ins Projekt aufgenommen werden möchten und denen es natürlich nicht verwehrt wird, zu dem fortgeschrittenen Zeitpunkt einzusteigen und Arbeitsaufgaben zu erhalten. So wird mit einer in der Zusammensetzung leicht wechselnden Gruppe anhand von drei ausgewählten Kochbüchern aus der Barockzeit (Conrad Haggers Neues Saltzburgisches Koch $=$ Buch von 1719 ${ }^{8}$, Susanne Maria Endters Vollständiges Nürnbergisches Kochbuch von 16919 ${ }^{9}$,

5 Vgl. https://www.artigo.org/ (letzter Zugriff: 30.11.2019).

6 Einen Überblick über aktive Citizen-Science-Projekte kann man sich auf den diversen nationalen Plattformen verschaffen, beispielsweise aus dem DACH-Raum: Bürger schaffen Wissen (www.buergerschaffenwissen.de), Österreich forscht (www.citizen-science.at) und Science et Cité (www.science-et-cite.ch/).

7 Vgl. Karin Portenkirchner: Bürger sollen helfen, die Barockküche zu erforschen. Salzburger Nachrichten, 30. August 2017. https://www.sn.at/salzburg/chronik/buerger-sollen-helfen-diebarockkueche-zu-erforschen-16852564 (letzter Zugriff: 08.05.2018)“.

8 Siehe Conrad Hagger: Neues Saltzburgisches Koch-Buch: Für Hochfürstliche und andere vornehme Höfe, Clöster, Herren-Häuser, Hof-und Hauß-Meister, Köch und Einkäuffer [...] ; Mit mehr dann 2500. Speisen, und 318. in schönen Kupffer gestochenen Formen [...] Bestehend aus 4. Theilen, in 8. Büchern eingetheilt [...], Augsburg 1719.

9 Siehe Susanna Maria Endter: [Vollständiges Nürnbergisches Kochbuch] Der aus dem Parnasso ehmals entlauffenen vortrefflichen Köchin / Welche bey denen Göttinnen Ceres, Diana und Pomona viel Jahre gedienet [...], Nürnberg: Endter 1691. http://diglib.hab.de/drucke/6oec/start.htm (letzter Zugriff: 12.03.2019). 
Marx Rumpolts Ein new Kochbuch von $1581^{10}$ ) mit insgesamt fast 6.500 Rezepten ${ }^{11}$, die barocke Küche in Salzburg vertiefend herausgearbeitet. Die Gruppe setzt sich dabei recht divers zusammen. Obwohl ein Überhang an (pensionierten) Frauen mit höherer Bildung, vor allem aus dem Lehrberuf, zu erkennen ist, finden sich in der sich herausgebildeten Kerngruppe auch Männer, Studierende sowie Personen aus komplett fachfremden Berufsgruppen. Gemein haben sie vor allem das inhärente Interesse an Ernährung und/oder Geschichte.

\section{Barocke Rezepte analysieren}

„Mich reizte [am Mitwirken an einem universitären Forschungsprojekt; Anm. der Autorin], Teil dieses Projektes zu sein und auch dabei meinen Wissensstand aus anderen Blickwinkeln zu erhöhen“ (Wolfram Kracker, Citizen Scientist).

Aufgrund der großen Datenmenge im Feld der historischen Kochbuchliteratur, insbesondere im Bereich der gedruckten Kochbücher ${ }^{12}$, die sich jeweils aus bis zu über 2.000 Rezepten zusammensetzen, ist das Zusammentragen und inhaltliche Bearbeiten der Rezepttexte als Vergleichsmaterial von unschätzbarem Wert, um einzelne Quellen in einen überregionalen Kontext stellen zu können. Die Arbeitshypothese lautet dabei, dass es schwerlich eine klassische regionale Küchentradition gibt, sondern vielmehr die Gerichte sowie Zubereitungsmethoden einen konstanten Kulturtransfer über Regionen und Ländergrenzen hinweg widerspiegeln. Derartige Annahmen lassen sich nur mittels entsprechender Datenmenge klären. Die im vorigen Absatz angegebenen Kochbücher sollen diese liefern, wobei Haggers Neues Saltzburgisches Kochbuch aufgrund des Salzburg-Bezugs ${ }^{13}$ prioritär behandelt wurde. Die ersten

10 Siehe Marx Rumpolt: Ein new Kochbuch. Das ist Ein grundtliche beschreibung wie man recht vnd wol, nicht allein von vierfüssigen, heymischen vnd wilden Thieren, sondern auch von mancherley Vögel vnd Federwildpret, darzu von allem grünen vnd dürren Fischwerck, allerley Speiß, als gesotten, gebraten, gebacken [...] auff Teutsche, Vngerische, Hispanische, Italianische vnnd Frantzösische weiß, kochen vnd zubereiten solle [...], Frankfurt am Main 1581. http://phaidra.univie.ac.at/o:515920 (letzter Zugriff: 12.03.2019).

11 Die 2.635 Rezepte aus Hagger zusammen mit 1.780 aus dem Nürnbergischen Kochbuch und 2.073 aus Rumpolts Kochbuch ergeben ein Arbeitspensum von 6.488 Rezepten, die es zu bearbeiten gilt. Die definitive Anzahl der Rezepte wird sich erst am Ende des Projekts herausstellen, wenn die Rezeptanzahl in der Datenbank gezählt wird. Bisher hat sich nämlich bereits gezeigt, dass die in den Kapitelzusammenfassungen der Kochbücher angegebenen Zahlen nicht immer korrekt sind, manche Rezepte die Nummerierung vermissen und auch Ergänzungen ganzer Rezepte im Anhang nicht berücksichtigt sind.

12 Vgl. Henry Notaker: Printed Cookbooks in Europe, 1470-1700. A Bibliography of Early Modern Culinary Literature, New Castle, Del. 2010.

13 Conrad Hagger war u. a. Stadtkoch in Salzburg und sein Werk wird aufgrund der zahlreich enthaltenen Schaugerichte inkl. dazugehörigen Kupferstichen als Paradebeispiel für die Hofkü- 
Arbeitspakete, die von der Größenordnung in etwa jeweils zehn Seiten und dabei im Schnitt 30 Rezepte enthalten, wurden aus verschiedenen Kapiteln aus Hagger zusammengestellt. Dadurch sollte den Citizen Scientists ein Einblick in die inhaltliche Vielfalt der barocken Kochbücher gegeben werden, was allerdings auch zu vermehrtem Verwaltungsaufwand führte. Für alle weiteren Pakete wurden zusammengehörige Kapitel bzw. Abschnitte gewählt. Dieser Wechsel in der Herangehensweise wurde auch von den Citizen Scientists positiv aufgenommen, da man dadurch Verwirrungen bzgl. Rezeptnummerierungen wie auch Kapitelzugehörigkeit besser ausschließen kann. Die beiden weiteren zu bearbeitenden Kochbücher wurden aufgrund ihrer überregionalen Bedeutung sowie Anzahl an Ausgaben gewählt. Eine Analyse der Entwicklungsstränge und Einflüsse der mittelalterlichen Küche - im Speziellen im Vergleich zu den handschriftlich festgehaltenen Quellen, die sich bereits in der Datenbank befinden - wird als äußerst interessantes Vorhaben erachtet. Das Projekt wurde derart konzipiert, dass im Schnitt jede Bürgerwissenschaftlerin und jeder Bürgerwissenschaftler sieben Arbeitspakete innerhalb der zweijährigen Laufzeit bearbeiten sollte. In Realität gab es allerdings große Unterschiede im bewältigten Arbeitspensum der Einzelpersonen - von einem erarbeiteten bis hin zu 46 von einer Person bearbeiteten Transkriptionspaketen. Die Rückmeldungen der Citizen Scientists lassen dabei erkennen, dass mit Mindestabgaben bzw. konkreten Abgabeterminen ruhig mehr Druck gemacht werden könnte. Wolfram Kracker hat es so ausgedrückt: „Wunschtermine zur Fertigstellung eines Arbeitsauftrages ließen zumindest bei mir weniger Arbeitspausen entstehen, als wenn zeitlich alles offen bleibt.“

Eine Erweiterung der zu bearbeitenden Quellen um weitere (fremdsprachliche) Exemplare (wie etwa Varennes ${ }^{14}$ und Scappis ${ }^{15}$ Werke) ist nicht ausgeschlossen, je nachdem wie sich der Bearbeitungsfortschritt in der CitizenScience-Gruppe noch entwickelt. Die Projektlaufzeit endete mit Dezember 2019 und mit der Unterstützung von Studienassistenten wird eine Endkontrolle hinsichtlich Vollständigkeit sowie Qualität der Einträge in der historischen

che gesehen. Für Details siehe Simon Edlmayr, Martina Rauchenzauner: Conrad Haggers Neues Saltzburgisches Koch=Buch von 1718/19 zwischen den Zeilen gelesen, in: Andrea HofmeisterWinter, Helmut W. Klug, Karin Kranich (Hrsg.): Der Koch ist der bessere Arzt. Zum Verhältnis von Diätetik und Kulinarik im Mittelalter und in der Frühen Neuzeit. Fachtagung im Rahmen des Tages der Geisteswissenschaften 2013 an der Karl-Franzens-Universität Graz, 20.6.22.6.2013. Frankfurt a. M. u. a. 2014, S. 139-150.

14 Siehe François Pierre de la Varenne: Le Cuisinier François, enseignant la manière de bien apprester et assaisonner toutes sortes de viandes [...], Lyon 1651. https://gallica.bnf.fr/ ark:/12148/bpt6k114423k (letzter Zugriff: 16.03.2019).

15 Siehe Bartolomeo Scappi: Opera di Bartolomeo Scappi Cvoco Secreto di Papa Pio Qvinto, Venedig: Michele Tramezzino 1570. https://reader.digitale-sammlungen.de/de/fs1/object/ display/bsb11122030_00005.html (letzter Zugriff: 16.03.2019). 
Rezeptdatenbank durchgeführt. Ende November 2019 waren dabei etwa $90 \%$ der Rezepte bereits in der Datenbank eingegeben.

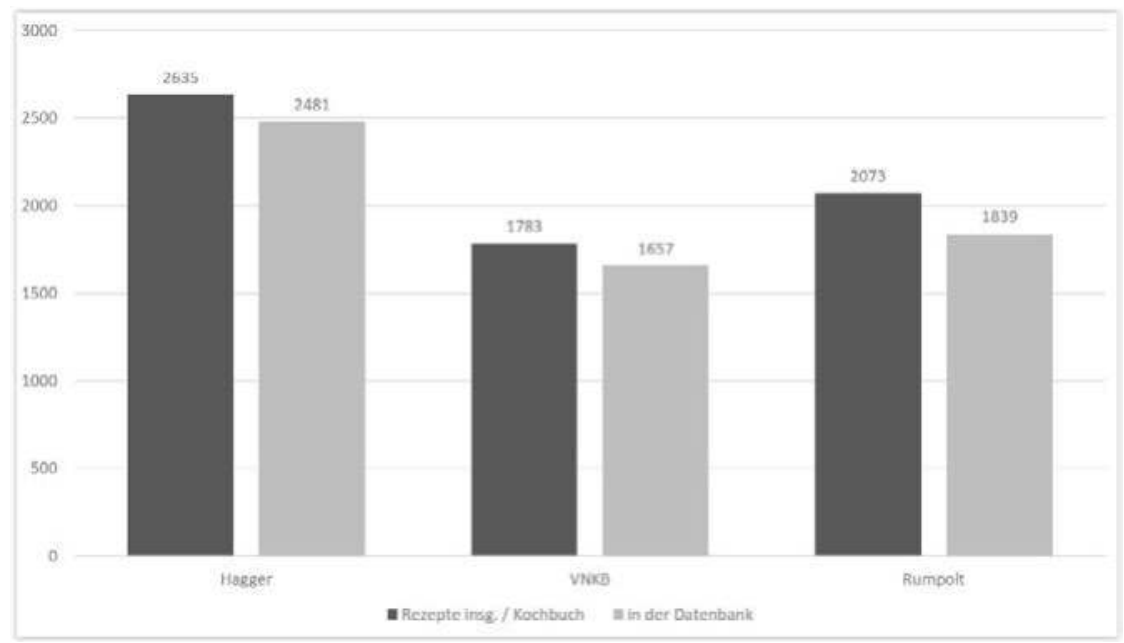

Abbildung 1: Erfüllungsstand nach Kochbüchern [Stand: November 2019].

Da eine spätere Erweiterung der Projektgruppe allerdings nicht ausgeschlossen wurde, im Gegenteil, gar erwünscht war (u. a. auch um das ,Wegbrechen' von Beteiligten ${ }^{16} \mathrm{zu}$ kompensieren) und auch dementsprechend gehandhabt wurde, bleibt dieses Potential weiterhin erhalten. Aus den beteiligten Citizen Scientists hat sich eine acht Personen umfassende Kerngruppe herausgebildet, von denen kaum ein Workshop ausgelassen und bei den Transkriptionsleistungen ein größerer Anteil übernommen wurde. Um die so entstandene Dynamik über das offizielle Projektende hinweg zu nutzen, soll die Möglichkeit zur weiteren Kooperation bzw. Mitarbeit gegeben werden. ${ }^{17}$ Quellenmaterial zur Bearbeitung geht so rasch nicht aus und bei manchen Citizen Scientists wurde jetzt erst so richtig der Forschergeist geweckt, wie sich auch in den Diskussionsrunden während der Abschlusstagung des Projekts gezeigt hat.

Die zeitnahe Einarbeitung eines solchen Umfangs an Rezepten in die Datenbank wäre ohne die Unterstützung der Citizen Scientists nicht machbar. Bei

16 Vereinzelt wurde die Mitarbeit durch persönliche Gründe, wie etwa Auslandsaufenthalt oder anderweitige Projektverpflichtungen, unmöglich. Eine Tatsache, auf die man sich ebenso bereits zu Beginn eingestellt hat, wie auch auf die unterschiedlichen Vorstellungen zu den Aufgaben innerhalb des Projekts.

17 Nachhaltigkeitsstrategien sollten bereits zu Projektbeginn konkret bedacht werden. Im vorliegenden Fall war es stets Ziel, das Forschungstool langfristig nutzbar zu machen und auch eine weiterführende Zusammenarbeit, über das offizielle Projektende hinaus, ist geplant. 
der Bearbeitung geht es dabei nicht allein um die Transkription, denn für die Auswertung sind auch Begriffsklärungen bei unbekannten bzw. unklaren Zutaten, materiellen Kulturgütern, diätetischen Verwendungen der Rezepte sowie Herkunftsbezeichnungen in den Texten nötig und die Citizen Scientists wurden auch in den diesbezüglichen Recherchemethoden geschult. Zusätzliche Veranstaltungen in Form von Praxisworkshops helfen nicht nur den Kontakt und die Motivation der Citizen Scientists aufrecht zu halten, sondern bieten vor allem auch eine ideale Möglichkeit zum Erfahrungsaustausch und Besprechen der Inhalte. Diese Spezialworkshops verfolgten dabei das zusätzliche Ziel, dem wachsenden Wissensgrad der Citizen Scientists Rechnung zu zollen. Begonnen wurde mit einer klassischen historischen Sicht auf vergangene Esstraditionen. Mit der Unterstützung eines experimentellen Archäologen wurde ein Huhn in Kren- bzw. Meerrettichsauce in historischem Ambiente im Freilichtmuseum Salzburg nachgekocht. Ein Rezept für die Speise findet sich in allen von den Citizen Scientists bearbeiteten Quellen wieder und beruft sich auf mittelalterliche Traditionen. In weiteren Workshops und Veranstaltungen wurde die Thematik in die Moderne geholt und mittels eines professionellen Kochs neu interpretiert. Besonderer Fokus lag dabei auf den Besonderheiten in den Gerichten (wie etwa heute unübliche Würzkombinationen). Mit diesem Wissensschatz bereichert wurde als Abschlusstreffen ein gemeinsames Kochen in einer Seminarküche durchgeführt. Die Citizen Scientists sowie Mitarbeiterinnen und Mitarbeiter der Gastrosophie haben dabei ein mehrgängiges Menü ausgearbeitet und zubereitet. Insbesondere die Diskussionen zu Mengenverhältnissen (z. B. wie viel Rosenwasser verträgt eine Maronisuppe?) wurden durch persönliche Erfahrungen und das durch die Transkriptions- und Editionsarbeit erlangte Mehrwissen bereichert. Durch den ungezwungenen Rahmen außerhalb von universitären Seminarräumen sind die dadurch hervorgerufenen Denkanstöße nicht zu unterschätzen. Die sich zusätzlich entwickelnde Gruppendynamik - manche Citizen Scientists treffen sich unabhängig von offiziellen Projektveranstaltungen, auch um sich über ihre Projektaufgaben auszutauschen bzw. etwaige Schwierigkeiten gemeinsam zu lösen - ist ein weiterer Faktor, den es zu berücksichtigen gilt. Zudem wurden auch vom Projektteam aus immer wieder informelle Stammtischtreffen organisiert, um den Gruppenzusammenhalt zu stärken. ${ }^{18}$ Insgesamt wurde die Kommunikations-

18 Die bedeutende Rolle der Kommunikationsstrategien in Citizen Science Projekten wird u. a. von Wuketich und Griessler oder auch Lehmann aufgegriffen. Vgl. Milena Wuketich, Erich Griessler: „Let's Talk Science - But How? Considering the Communicational Challenges of Citizen Science“, in: Daniel Dörler, Florian Heigl, Taru Sandén (Hrsg.): Austrian Citizen Science Conference 2017 - Expanding Horizons, Wien 2017, S. 21-24; Hanna Lehmann: „Kommunikation - Nähe nutzen, Brücken bauen“, in: Peter Finke (Hrsg.): Freie Bürger, freie Forschung: Die Wissenschaft verlässt den Elfenbeinturm, München 2015, S. 85-89. 
kultur von beiden Seiten - Wissenschaftlerinnen und Wissenschaftler wie auch Citizen Scientists - als eine sehr positive und wertschätzende empfunden. Der gemeinsame Nenner, das Interesse an Ernährungsgeschichte, hat zu einem besonderen Zusammengehörigkeitsgefühl geführt.

Offen für neue Ideen und Ansätze zu sein ist ein Muss, wenn man sich mit der Citizen-Science-Methode auseinandersetzt. Oftmals ist die Kreativität der Forscherinnen und Forscher gefragt, um sich vom „Elfenbeinturm der Wissenschaft" hinauszuwagen. ${ }^{19}$ Es hat sich auch in dem vorliegenden Fallbeispiel gezeigt: Allein die - oft unerwarteten - Fragen der mitwirkenden Citizen Scientists geben Denkanstöße. Um die an das Historikerteam herangetragenen Unklarheiten beantworten zu können, bedarf es des Öfteren interessanter, aufschlussreicher sowie unerwarteter Recherchewege, die auch auf Forscherseite zu Aha-Momenten führen.

Für Salzburg zu Tisch und die Bearbeitung von historischen Rezepten ebenso relevant sind das küchenspezifische Spezialwissen und die häufig mitgebrachte Praxiserfahrung der Citizen Scientists, die das Interpretieren der historischen Texte erleichtern. So etwa geschehen bei einem Begriff in dem am Anfang des Textes angeführten Rezept: In den Einführungsworkshops wurde die Khanußl als Beispiel für einen noch zu klärenden Begriff angeführt, denn das Wort in dieser Schreibweise konnte bis dahin noch nicht geklärt werden und kommt (bis heute) nur in diesem einen Rezept vor (von mittlerweile 8.200, die sich in der Datenbank befinden). Erst durch das Citizen-Science-Projekt und die Erweiterung des Personenkreises, der sich mit den Quellen sowie offenen Fragestellungen beschäftigt, wurde der Begriff durch die Bürgerwissenschaftlerin Andrea Sobieszek als Kornelkirsche identifiziert. ${ }^{20}$

Die Ernährungsgeschichte ist ein äußerst faszinierendes Forschungsgebiet, das breitgestreute Fragestellungen zulässt. Die historischen Kochbücher lassen uns dabei über den Tellerrand hinausschauen. Die Kochbuchliteratur gibt nicht allein Aufschluss über Rezepte und Zubereitungsmethoden vergangener Zeiten. ${ }^{21}$ Neben diesem augenscheinlichen Wissensgewinn bietet sie ebenso Zugang zur Wirtschafts- und Handelsgeschichte, denn die Rezepte gewähren u. a. Einblick in Produkthäufigkeiten und auch die geographische Verbreitung

19 Vgl. Peter Finke: Lob der Laien. Eine Ermunterung zum Selberforschen, München 2018, S. 1216.

20 Durch Verballhornung der lateinischen Bezeichnung cornus gelangt man zu den Khanußln, die auch geschmacklich durchaus passend für eine Birnenpastete sind.

21 Vgl. Anne Willian, Mark Cherniavsky, Kyri Claflin: The Cookbook Library. Four Centuries of the Cooks, Writers, and Recipes That Made the Modern Cookbook, Berkley/Los Angeles/London 2012. In der Einleitung heißt es dort: „Old Cookbooks are captivating, and important too, leading us into the world beyond the hearth. Without them, we would not have tasted our way down the centuries to the dishes we embrace with such affection today." 
von exotischen Zutaten. Unterschiede und Ähnlichkeiten im Essverhalten in den sozialen Schichten lassen sich ebenfalls erkennen. Daneben zeugt diese Quellengattung von der materiellen Kultur (u. a. wie mussten die jeweiligen Küchen und Silberkammern eingerichtet sein, um die Speisen zubereiten bzw. anrichten zu können). Nicht zu vernachlässigen ist auch der Wissensgewinn für die Sprachgeschichte. Kochbuchhandschriften sind für die ausgewählte Bearbeitungszeit oftmals die einzig verbliebenen Zeugen für die damalige Umgangssprache (in den gedruckten Werken findet man in der Regel nur die Hochsprache) und somit eine wertvolle Quelle für Germanisten bzw. Linguisten.

Die Herausforderungen in der Bearbeitung bzw. Aufarbeitung der barocken Rezepttexte sind mannigfaltig und ebenso vielschichtig ist der Einsatz von digitalen Hilfsmitteln dabei. Ein großer Vorteil bei diesem Projekt ist die Vereinigung der technischen Arbeiten mit der Betreuung der Citizen Scientists bzw. Projektkoordination der historischen Forschung in Personalunion. Die Programmierung sowie technische Weiterentwicklung der historischen Rezeptdatenbank, die ein Teil des Dissertationsvorhabens der Autorin war, ${ }^{22}$ wird aus einer Hand vollzogen, was es erlaubt, Anfragen der Citizen Scientists rascher und effizienter beantworten und allgemeine technische Probleme schneller beheben zu können. Ist eine solche Variante nicht möglich, sollte besonderer Wert auf eine möglichst enge Zusammenarbeit zwischen Entwickelndem bzw. Programmierenden und Citizen-Science-Koordinatorin oder Koordinator gelegt werden. Bereits bei der Projektkonzeption war klar, dass die digitale Komponente eine besondere Herausforderung darstellen wird. Aus diesem Grund traf das Projektteam die bewusste Entscheidung, die Einschulung in die Transkriptionstätigkeit voranzustellen und erst in einem zweiten Schritt, nach Einarbeitung in die Thematik, mit der technischen Schulung auf die Eingabe in die Datenbank vorzubereiten. Diese Herangehensweise wurde sehr positiv aufgenommen und verhinderte das vorzeitige Abspringen einiger Citizen Scientists. $\mathrm{Zu}$ diesen Schulungen gehörten unweigerlich entsprechende Unterlagen, die mittels zahlreicher Screenshots eine Schritt-für-Schritt-Anleitung zu den Eingabemodalitäten boten. In zweistündigen Workshops wurden Beispieleingaben getätigt und auf potentielle Schwierigkeiten und Sonderfälle hingewiesen. Dennoch war es vor allem die individuelle (Mail-)Kommunikation, über die Fragen der Citizen Scientists beantwortet wurden.

Eine systematische Auswertung des so aufbereiteten Quellenmaterials wird durch eine am Zentrum entwickelte und bereits mehrfach angesprochene

22 Vgl. Marlene Ernst: Rezepte für das digitale Zeitalter. Computerunterstützte Aufarbeitung von kulturhistorischen Quellenkorpora gezeigt anhand von Kochbuchliteratur der Frühen Neuzeit, Dissertation, Universität Salzburg 2019. 
Rezeptdatenbank ${ }^{23}$ ermöglicht. In ihr sind bisher vor allem barocke Kochbuchhandschriften aus der Region eingepflegt. Die Erweiterung durch die (teilweise überregionalen) gedruckten Werke erlaubt zukünftig die Beantwortung zahlreicher Fragestellungen, wie etwa nach der Herkunft einzelner Rezepte (wer hat von wem abgeschrieben), regionale Verbreitung oder auch nach erstmaligem Aufscheinen von Gerichten oder (exotischen) Zutaten.

\title{
4 Digitale Hilfsmittel und wie sie von den beteiligten Bürgerwissen- schaftlerinnen und Bürgerwissenschaftlern aufgenommen werden
}

\begin{abstract}
„Die Transkription war relativ einfach, wenn man sich einmal ,eingelesen' hatte. Das Merkblatt des Fraktur-Alphabets war dabei sehr hilfreich. Wenn sich Übersetzungsfehler einschlichen, so fielen mir diese bei der Eingabe in die Datenbank auf. Die Recherche war zeitaufwendig. Je mehr Glossar in der Datenbank war, desto einfacher wurde es. Außerdem gab es immer den Telefonjoker (Email-Joker) Marlene. Nach einer Einschulung war das Einpflegen der transkribierten Rezepte in die Datenbank auch kein Problem mehr. Die Datenbank ist sehr übersichtlich und nach den üblichen Anfangsschwierigkeiten selbsterklärend“ (Helga Kraihamer, Citizen Scientist).
\end{abstract}

In dem bürgerwissenschaftlichen Projekt vermischt sich Citizen Science mit den Digital Humanities durch die Nutzung der historischen Rezeptdatenbank als Eingabe- sowie Forschungstool. Die computerunterstützte Bearbeitung von historischen Daten erfolgt bereits seit Einzug des Computers in den Alltag. Die digitale Edition von Quellenmaterial wird seitdem ständig weiter professionalisiert und standardisiert. Zudem gehören online zugängliche Digitalisate (oftmals auch mit thematischen Schwerpunktbibliotheken ${ }^{24}$ ) mittlerweile zum Standardrepertoire auch der Geistes- und Kulturwissenschaften. Die am Zentrum für Gastrosophie entwickelte Datenbank für historische Rezepte geht noch einen Schritt weiter und unterstützt die Auswertung und Vergleiche von Rezepten - egal ob sie aus gedruckten Kochbüchern oder Handschriftensammlungen stammen - durch ein Kategorisierungsschema sowie den Einsatz von einschlägigen Metadaten für jedes Rezept (u. a. zu diätetischen Verwendungen von Rezepten, verwendeten materiellen Kulturgütern oder Herkunftsbezeich-

23 Die Datenbank mit über 8.200 Rezepten (Stand: 12.12.2019) kann über folgenden Link eingesehen werden: http://gastrosophie.sbg.ac.at/kbforschung/r-datenbank/.

24 Im Falle von Kochbuchforschungsrelevanten Quellen siehe z.B. die Wellcome Library mit ihren englischsprachigen diätetischen Texten (www.wellcomelibrary.org, letzter Zugriff: 30.11.19) oder die Monumenta Culinaria et Diaetetica Historica von Dr. Gloning an der Universität Gießen (www.staff.uni-giessen.de/gloning/kobu.htm, letzter Zugriff: 30.11.19). 
nungen). ${ }^{25}$ Über 8.200 Rezepte aus Handschriften (vor allem aus dem Salzburger Regionalraum) und ausgewählten gedruckten Kochbüchern aus dem späten 15. bis ins 18. Jahrhundert sind so - unabhängig von Unterschieden in den jeweiligen Editionspraktiken - in die Datenbank aufgenommen worden und stehen für statistische Auswertungen und Vergleiche zur Verfügung. Dank der Mitarbeit der Citizen Scientists, die nicht nur die Transkription der Texte, sondern auch deren inhaltliche bzw. editorische Bearbeitung sowie die Eingabe in die Datenbank übernommen haben, nimmt die Zahl der Einträge rapide zu und am Ende des Top-Citizen-Science-Projekts werden diese Daten über die historische Rezeptdatenbank auch öffentlich zugänglich gemacht. Mit den Citizen Scientists wurde bereits im Einführungsworkshop zu Beginn des Projekts abgeklärt und mittels entsprechender schriftlicher Einverständniserklärung ihrerseits bestätigt, ${ }^{26}$ dass bei jedem von ihnen bearbeiteten Rezept ihr Name als Bearbeiterin bzw. Bearbeiter aufscheinen wird. Es war der Projektleitung sehr wichtig, von Anfang an klarzustellen, dass die individuellen Leistungen im wissenschaftlichen Kontext auch gewürdigt werden sollen - die gegenseitige Wertschätzung ist ein zentraler Punkt bei der Anwendung der CitizenScience-Methode. Jedes Rezept weist aus diesem Grund am Ende eine Zitierempfehlung mit Angabe zur Transkriptionserstellung auf. Für die gesamten Datenbank-Inhalte ist ein CC BY-NC-SA-Lizenzmodell angedacht. ${ }^{27}$

Die größte Herausforderung liegt darin, die digitale Komponente mit dem Citizen-Science-Ansatz zu verbinden. Ein Knackpunkt dabei ist wiederum, wie sich wiederholt gezeigt hat, die konstante Betreuung und vor allem auch die Benutzerfreundlichkeit des Eingabeformulars. Bereits bei der Konzeption des Systems wurde darauf Rücksicht genommen und mit Wordpress ein CMSSystem als Basis gewählt, das sich besonders durch die bedienerfreundliche Oberfläche, ein gutes Supportnetzwerk und hervorragende Individualisierungsmöglichkeiten auszeichnet. Diejenigen unter den Citizen Scientists, die sich auf diesen digitalen Aspekt eingelassen und sich mit der Datenbank (intensiver) auseinandergesetzt haben, sind durchwegs zufrieden mit dem Aufbau und der Handhabung. Nicht alle Beteiligten sahen sich allerdings im Stande, diese Anfangshürde auf sich zu nehmen und beschränkten sich auf die Transkription sowie Begriffsklärung innerhalb der Rezepte. Die Eingabe dieser Rezepte wurde von Studienassistentinnen und Studienassistenten am Zentrum für Gastrosophie übernommen. Dadurch gingen die erbrachten Leistungen

25 Das zugrundeliegende relationale Datenbankmodell wurde in einer Wordpress-Seite mittels Custom Post Types sowie Taxonomien umgesetzt.

26 Diese enthielt auch Punkte zur Bildnutzung von Veranstaltungsfotos, beispielsweise für Social Media.

27 Dies muss allerdings noch mit der universitären Rechtsabteilung abgeklärt werden. 
nicht verloren bzw. mussten nicht erneut erbracht werden. Durch die vielen unterschiedlichen Personen, die mittlerweile Daten in das System eingeben, hat sich allerdings auch gezeigt, dass zahlreiche Dubletten in den einzugebenden Metadaten aufscheinen - alleine die Zutatenliste umfasst mittlerweile über 1.800 Einträge. Die Konsolidierung und Bereinigung dieser Daten muss von zentraler Stelle immer wieder vorgenommen werden, ist allerdings im vorliegenden Fall durch Massenupdates und wiederum durch die einfache sowie intuitive Handhabung innerhalb von Wordpress relativ rasch zu bewältigen.

Die Citizen Scientists der Arbeitsgruppe haben es treffenderweise so formuliert, dass sie selbst nicht zu den Digital Natives der jüngeren Generationen gehören. Oftmals müssen bei technischen Problemen oder Unklarheiten ihre Kinder herhalten und IT-Help-Desk-Funktionen übernehmen. Auffallend ist auch, dass viele zuerst bei sich selbst die (Bedienungs-)Fehler suchen, anstatt wie oft in Unternehmen üblich - dem System oder den Entwickelnden die Schuld zu geben. Wie im Projektantrag ursprünglich konzipiert, wurde auch ein Forum für die Citizen Scientists in die Datenbankoberfläche integriert. Diese Funktion wird jedoch kaum bis gar nicht verwendet und alle Beteiligten greifen lieber auf das Schreiben von Mails oder den persönlichen Austausch während der Bürozeiten bzw. während der regelmäßig stattfindenden Veranstaltungen zurück. Probleme in den öffentlichen Raum zu stellen, ist eine Hemmschwelle, die bisher nur ganz vereinzelt überwunden wurde. Um diese zu verringern, wurden einige Threads zu häufig vorkommenden unklaren Begriffen vorab veröffentlicht. Doch bisher gab es nur einen einzigen CitizenScientist-Eintrag im Forum, auf den sich - wie sich später herausgestellt hat eine andere Bürgerwissenschaftlerin direkt bei der betreffenden Person mit einer Antwort gemeldet hat und die potentielle Lösung nicht über das Forum weitergegeben wurde. Die Kommunikation über Emails wird hingegen sehr gut angenommen, wobei von Projektbetreuungsseite her versucht wird, diese möglichst zeitnah und unabhängig von den eigentlichen Bürozeiten zu beantworten. Ohne diesen Einsatz würden sich die Citizen Scientists schnell alleine gelassen fühlen und der Projektfortschritt würde Gefahr laufen, behindert zu werden. Diese intensive Betreuung wird äußert positiv wahrgenommen und in den Rückmeldungen der Citizen Scientists stets hervorgehoben. Zusammen mit den geselligen und ungezwungenen Praxisworkshops macht diese Kommunikationskultur einen bedeutenden Aspekt des Kooperationsprojekts zwischen Laien und der Wissenschaft aus. ${ }^{28}$

28 Vgl. Eva Lang: „Gesellschaft - Profi-Laien-Mix schafft Mehrwert“, in: Peter Finke (Hrsg.): Freie Bürger, freie Forschung: Die Wissenschaft verlässt den Elfenbeinturm, München 2015, S. 9094, hier S. 93. 


\section{Fazit}

„Ich habe die Arbeit als Bereicherung empfunden: mein Wissenshorizont wurde erweitert, ich konnte aber auch mein eigenes Vorwissen und meine ,kulinarischen Erfahrungen' zum Thema nutzen und einbringen und Anregungen machen / Hinweise geben, z.B. zu entdeckten Querverbindungen zwischen den Kochbüchern, Auflösung von ,Verballhornungen' etc. Es war selbstständige Arbeit möglich mit ansatzweise eigenständigen Entscheidungen (wenn auch nicht von großer Tragweite) beim Einpflegen in die Datenbank“ (Andrea Sobieszek, Citizen Scientist).

Wenn die Thematik für einen ausreichend großen Teil der Bevölkerung von maßgeblichem Interesse und eine sinnvolle Einbindung in die Forschung möglich ist, dann kann Citizen Science eine große Bereicherung für alle Beteiligten sein - und das nicht nur, wenn es sich um klassische Citizen-Science-Projekte aus der Biodiversitätsforschung handelt. Nicht zu unterschätzen ist allerdings der damit einhergehende Arbeitsaufwand bei dem Einsatz der Methodik. Kann oder will man die nötigen Stunden nicht in die Kommunikation mit den freiwilligen Mitarbeiterinnen und Mitarbeitern stecken, sollte man die Integration eines Citizen-Science-basierten Ansatzes überdenken, denn nichts hinterlässt einen schlechteren Eindruck als mangelnder Kommunikationswille. Lässt man sich allerdings darauf ein, so ist die Zusammenarbeit ein großer Gewinn nicht nur inhaltlich für ein Projekt, sondern auch auf persönlicher Ebene in der gegenseitigen Wertschätzung und dem Austausch.

\section{Literaturverzeichnis}

Simon Edlmayr, Martina Rauchenzauner: Conrad Haggers Neues Saltzburgisches Koch=Buch von 1718/19 zwischen den Zeilen gelesen, in: Andrea Hofmeister-Winter, Helmut W. Klug, Karin Kranich (Hrsg.): Der Koch ist der bessere Arzt. Zum Verhältnis von Diätetik und Kulinarik im Mittelalter und in der Frühen Neuzeit. Fachtagung im Rahmen des Tages der Geisteswissenschaften 2013 an der Karl-Franzens-Universität Graz, 20.6.-22.6.2013, Frankfurt a. M. u. a. 2014, S. 139-150.

Susanna Maria Endter: [Vollständiges Nürnbergisches Kochbuch] Der aus dem Parnasso ehmals entlauffenen vortrefflichen Köchin / Welche bey denen Göttinnen Ceres, Diana und Pomona viel Jahre gedienet [...], Nürnberg: Endter 1691. http://diglib.hab.de/ drucke/6-oec/start.htm.

Marlene Ernst: Rezepte für das digitale Zeitalter. Computerunterstützte Aufarbeitung von kulturhistorischen Quellenkorpora gezeigt anhand von Kochbuchliteratur der Frühen Neuzeit, Dissertation, Universität Salzburg 2019.

Peter Finke: Lob der Laien. Eine Ermunterung zum Selberforschen, München 2018.

Conrad Hagger: Neues Saltzburgisches Koch-Buch: Für Hochfürstliche und andere vornehme Höfe, Clöster, Herren-Häuser, Hof-und Hauß-Meister, Köch und Einkäuffer [...] ; Mit 
mehr dann 2500. Speisen, und 318. in schönen Kupffer gestochenen Formen [...] Bestehend aus 4. Theilen, in 8. Büchern eingetheilt [...], Augsburg 1719.

Eva Lang: „Gesellschaft - Profi-Laien-Mix schafft Mehrwert“, in Peter Finke (Hrsg.): Freie Bürger, freie Forschung: Die Wissenschaft verlässt den Elfenbeinturm, München 2015, S. 90-94.

Hanna Lehmann: „Kommunikation - Nähe nutzen, Brücken bauen“, in: Peter Finke (Hrsg.): Freie Bürger, freie Forschung: Die Wissenschaft verlässt den Elfenbeinturm, München 2015, S. 85-89.

Henry Notaker: Printed Cookbooks in Europe, 1470-1700. A Bibliography of Early Modern Culinary Literature, New Castle, Del. 2010.

Karin Portenkirchner: Bürger sollen helfen, die Barockküche zu erforschen. Salzburger Nachrichten, 30. August 2017. https://www.sn.at/salzburg/chronik/buerger-sollen-helfendie-barockkueche-zu-erforschen-16852564.

Marx Rumpolt: Ein new Kochbuch. Das ist Ein grundtliche beschreibung wie man recht vnd wol, nicht allein von vierfüssigen, heymischen vnd wilden Thieren, sondern auch von mancherley Vögel vnd Federwildpret, darzu von allem grünen vnd dürren Fischwerck, allerley Speiß, als gesotten, gebraten, gebacken [...] auff Teutsche, Vngerische, Hispanische, Italianische vnnd Frantzösische weiß, kochen vnd zubereiten solle [...], Frankfurt am Main 1581. http://phaidra.univie.ac.at/o:515920.

Bartolomeo Scappi: Opera di Bartolomeo Scappi Cvoco Secreto di Papa Pio Qvinto, Venedig: Michele Tramezzino 1570. https://reader.digitale-sammlungen.de/de/fs1/object/display/ bsb11122030_00005.html.

François Pierre de la Varenne: Le Cuisinier François, enseignant la manière de bien apprester et assaisonner toutes sortes de viandes [...], Lyon 1651. https://gallica.bnf.fr/ark:/12148/ bpt6k114423k.

Anne Willian, Mark Cherniavsky, Kyri Claflin: The Cookbook Library. Four Centuries of the Cooks, Writers, and Recipes That Made the Modern Cookbook, Berkley/Los Angeles/London 2012.

Milena Wuketich, Erich Griessler: „Let's Talk Science - But How? Considering the Communicational Challenges of Citizen Science“, in: Daniel Dörler, Florian Heigl, Taru Sandén (Hrsg.): Austrian Citizen Science Conference 2017 - Expanding Horizons, Wien 2017, S. 21-24. 


\section{Elementare Interaktionen. Eine web-basierte Methode der multikriteriellen Entscheidungsunterstützung}

\section{Einleitung}

Multikriterielle Entscheidungsanalyse (engl.: Multi-Criteria Decision Analysis (MCDA)) bezeichnet eine Gruppe von Entscheidungsunterstützungsansätzen, die bei Entscheidungsproblemen mit mehr als einem zu optimierenden Kriterium Hilfestellung geben. ${ }^{1}$ Ein vereinfachtes, aber typisches Entscheidungsproblem ist das der Planung einer Reise. Kriterien, die hier herangezogen werden können, sind die Kosten der Reise, die Reisezeit oder die Umweltbelastung, ausgedrückt beispielsweise in $\mathrm{CO}_{2}$-Äquivalenten. Ein oft genutzter Ansatz der MCDA nutzt für derartige Entscheidungsprobleme ein Zielsystem, d.h. eine hierarchische Struktur von Teilzielen, Kriterien und Indikatoren. ${ }^{2}$ Das Bewertungsziel wird unterteilt in Teilziele. Jedem der Teilziele werden Kriterien zugeordnet. Kriterien werden durch ein oder mehrere Indikatoren gemessen. Abbildung 1 skizziert ein mögliches Zielsystem für das Entscheidungsproblem der Reiseplanung.

Selten ist die Anwendung eines MCDA-Werkzeugs einfach, da notwendige Daten beschafft sowie Wichtungen ermittelt und in einen Zahlenwert überführt werden müssen. Auch der Entwicklungsprozess eines MCDA-Werkzeugs gilt als anspruchsvoll ${ }^{3}$ und wird häufig als sehr zeit- und kostenintensiv angesehen. ${ }^{4}$ Dieser Artikel führt daher in einen Citizen Science (CS)-Ansatz zur

1 Valerie Belton, Theodor J. Stewart: Multiple Criteria Decision Analysis - An Integrated Approach, 2002. https://doi.org/10.1007/978-1-4615-1495-4.

2 Andrea Lück, Ilka Nyga: Experiences of stakeholder participation in multi-criteria decision analysis (MCDA) processes for water infrastructure, in: Urban Water Journal, 15 (2018) 6, S. 508-517. https://doi.org/10.1080/1573062X.2017.1364394.

3 Lück, Nyga, 2018.

4 Judit Lienert, Florian Schnetzer, Karin Ingold: Stakeholder analysis combined with social network analysis provides fine-grained insights into water infrastructure planning processes, in: Journal of Environmental Management, 125 (2013), S. 134-148. https://doi.org/DOI 10.1016/ 
Entwicklung von MCDA-Werkzeugen ein, der die Komplexität des Entwicklungsprozesses wesentlich reduzieren soll. Dementsprechend werden im Folgenden die Grundlagen der Entwicklung von MCDA-Werkzeugen erörtert.

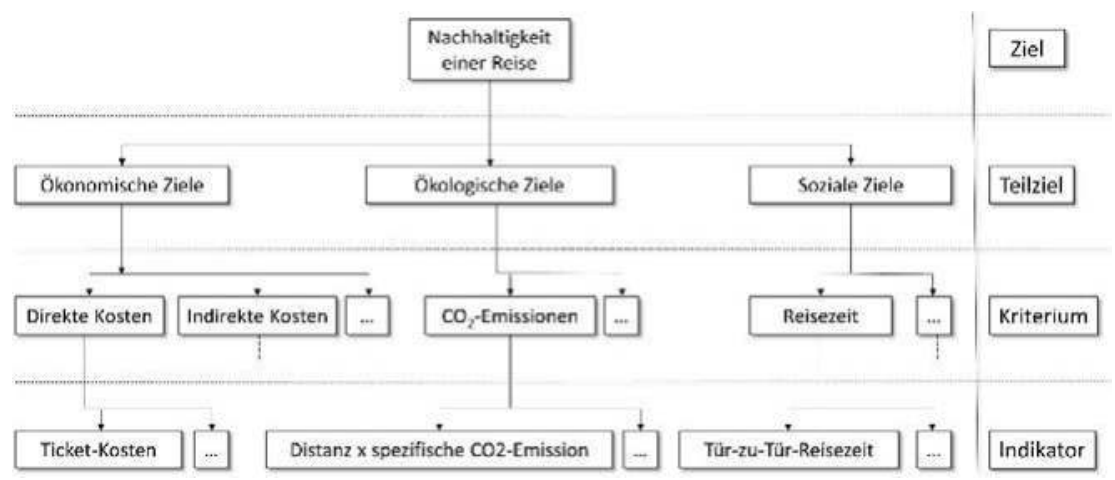

Abbildung 1: Hierarchische Struktur eines Zielsystems am Beispiel des Entscheidungsproblems einer Reiseplanung.

\subsection{Entwicklung eines Zielsystems}

Für die Durchführung einer MCDA werden in der Regel die folgenden Schritte durchgeführt: ${ }^{5}$

(1) Entscheidungskontext klären;

(2) Ziele und Attribute definieren;

(3) Alternativen entwickeln;

(4) Konsequenzen abschätzen;

(5) Kompromisse bewerten und Alternativen auswählen und

(6) umsetzen, überwachen und überprüfen.

Die Entwicklung eines Zielsystems erfolgt in den Schritten 1 und 2 und beinhaltet die Definition des Bewertungsziels und die Sammlung von Teilzielen,

j.jenvman.2013.03.052; Mika Marttunen u. a.: How to design and realize participation of stakeholders in MCDA processes? A framework for selecting an appropriate approach, in: EURO Journal on Decision Processes, 3 (2015) 1-2, S. 187-214. https://doi.org/10.1007/s40070-0130016-3.

5 Robin Gregory u. a.: Structured Decision Making: A Practical Guide to Environmental Management Choices, Wiley-Blackwell 2012. 
Kriterien und Indikatoren. ${ }^{6}$ Abbildung 2 zeigt den allgemeinen Aufbau eines Zielsystems für eine Nutzwertanalyse. Neben den Wichtungen wird das Zielsystem durch Transformationsfunktionen ergänzt, die den ermittelten Wert eines Indikators in einen Eingabewert für die weitere Berechnung umwandeln, beispielsweise durch Sprungfunktionen. Das Zielsystem repräsentiert objektive Aspekte des MCDA-Werkzeugs, während die Wichtungen die subjektiven Präferenzen darstellen. Ein Beispiel für die Differenzierung objektiver Fakten und subjektiver Präferenzen im Rahmen einer Bewertung ist der nukleare Unfall von Fukushima. Durch den Unfall wurden keine Fakten geändert, aber die Präferenzen der Bürgerinnen und Bürger haben sich geändert und zu einem Ausstieg aus der Kernenergie in Deutschland geführt. ${ }^{7}$

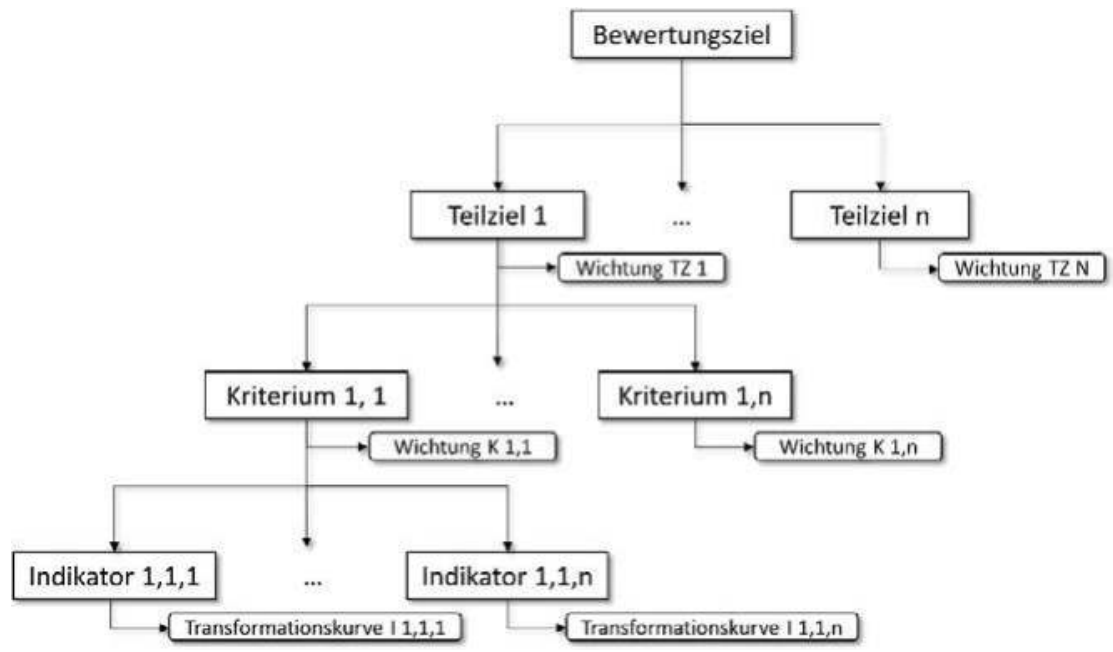

Abbildung 2: Allgemeine Struktur eines Zielsystems.

6 Lück, Nyga, 2018; Ilka Nyga u. a.: Rahmenkonzepte zur integrierten Bewertung siedlungswasserwirtschaftlicher Systeme, Gwf-Wasser|Abwasser, 1 (2018), S. 53-62.

7 Lukas Hermwille: The role of narratives in socio-technical transitions-Fukushima and the energy regimes of Japan, Germany, and the United Kingdom, in: Energy Research \& Social Science 11 (2016), S. 237-246. https://doi.org/10.1016/j.erss.2015.11.001; Ortwin Renn, Jonathan Paul Marshall: Coal, nuclear and renewable energy policies in Germany: From the 1950s to the ,Energiewende', in: Energy Policy, 99 (2016), S. 224-232. https://doi.org/10.1016/j.enpol. 2016.05.004. 


\subsection{Einbindung betroffener Interessengruppen}

In der Entwicklung von MCDA-Werkzeugen kommt der Einbindung der betroffenen Interessengruppen (engl.: stakeholder) eine besondere Rolle zu, die zwar nicht als zwingend erforderlich, aber als ergebnisverbessernd angesehen wird. ${ }^{8}$ So integrieren mehrere MCDA-Varianten die Einbeziehung der Interessengruppen. $\mathrm{Zu}$ diesen Varianten gehören der Decision Analysis InterviewAnsatz ${ }^{9}$, Stakeholder Multi-Criteria Decision Aid ${ }^{10}$, Participatory Analytical Hierarchy Process (AHP $)^{11}$, Decision Conferencing ${ }^{12}$ und Multi-Actor MultiCriteria Analysis (MAMCA) ${ }^{13}$.

Im Allgemeinen können Interessengruppen in vielen Phasen eines MCDAEntwicklungsprozesses eingebunden werden. Als vorteilhaft wird neben der Einbeziehung von Wissen und Werten der Interessengruppen auch eine verbesserte Planungsstruktur sowie die Schaffung von Diskussionsrahmen und Lerneffekten bei den Beteiligten selbst gesehen. ${ }^{14}$ Demgegenüber steht der unterschiedliche fachliche Hintergrund, den die an einem MCDAEntwicklungsprozess beteiligten Interessengruppen gemeinhin aufweisen. Dadurch wird der gemeinsame Entwicklungsprozess transdisziplinär und erfordert die Integration verschiedener Ebenen kognitiver Fähigkeiten, Ge-

8 Thomas L. Saaty: How to make a decision: The analytic hierarchy process, Desicion Making by the Analytic Hierarchy Process, in: Theory and Applications, 48 (1990) 1, S. 9-26. https:// doi.org/http://dx.doi.org/10.1016/0377-2217(90)90057-I; Ralph L. Keeney: Value-focused thinking. A path to creative decision making, (überarb. Auflage). Harvard University Press, 1996; Claude Banville u. a.: A stakeholder approach to MCDA, Systems Research and Behavioral Science, 15 (1998) 1, S. 15-32; Risto Lahdelma, Pekka Salminen, Joonas Hokkanen: Using multicriteria methods in environmental planning and management, Environmental Management, 26 (2000) 6, S. 595-605; Belton u. a. 2004; Astrid Hendriksen u. a.: Participatory Decision Making for Sanitation Improvements in Unplanned Urban Settlements in East Africa, Journal of Environment and Development, 21 (2012) 1, S. 98-119. https://doi.org/10.1177/1070496511426 778, Marttunen u. a.: How to design and realize participation of stakeholders in MCDA processes? A framework for selecting an appropriate approach, 2015.

9 Marttunen u. a.: How to design and realize participation of stakeholders in MCDA processes? A framework for selecting an appropriate approach, 2015, S. 187-214 https://doi.org/10.1007/ s40070-013-0016-3.

10 Banville u. a. 1998.

11 Paula Antunes u. a.: Participatory multi-criteria analysis of irrigation management alternatives: the case of the Caia irrigation district, Portugal, International Journal of Agricultural Sustainability, 9 (2011) 2, S. 334-349; https://doi.org/10.1080/14735903.2011.582358.

12 Lawrence D. Philipps, Carlos A. Bana E Costa: Transparent prioritisation, budgeting and resource allocation with multi-criteria decision analysis and decision conferencing, Annals of Operations Research, 154 (2007) 1, S. 51-68. https://doi.org/10.1007/s10479-007-0183-3.

13 Cathy Macharis, Astrid De Witte, Jeroen Ampe: The multi-actor, multi-criteria analysis methodology (MAMCA) for the evaluation of transport projects: Theory and practice, Journal of Advanced Transportation, 2009. https://doi.org/10.1002/atr.5670430206.

14 Marttunen u.a 2015. 
wohnheiten und Kulturen. ${ }^{15}$ Für das Anwendungsgebiet der Bürgerbeteiligung - der Teilhabe von Bürgerinnen und Bürgern an politischen Entscheidungen und Planungsprozessen - verweisen auch Hendriksen u. a. (2012) ${ }^{16}$ auf den großen Kontrast zwischen fachspezifischem Wissen und Erfahrungen der beteiligten Bürgerinnen und Bürger und Expertinnen und Experten.

In der Literatur werden verschiedene partizipative Methoden diskutiert. ${ }^{17}$ Das Spektrum der Methoden reicht von Workshop, Stakeholder-Gruppentreffen, Interview, schriftliche Umfrage, Brainstorming und Schreiben über morphologische Analyse bis zu Literaturrecherche und Expertengremium. ${ }^{18}$ Die Anwendung derartiger Methoden ist zeit- und personalintensiv. ${ }^{19}$ Durch die Anwendung partizipativer Ansätze in Präsenzveranstaltungen (z.B. Workshops, Sitzungen, Panels) können strategische, taktische, soziale und psychologische Fragen den eigentlichen MCDA-Entwicklungsprozess behindern. ${ }^{20}$ Auch wurden negative Effekte wie Dominanz von Stakeholdern ${ }^{21}$, strategische Antworten von Interessenvertreterinnen und Interessenvertretern ${ }^{22}$ und

15 Alexander I. Walter, Armin Wiek, Roland W. Scholz: Constructing Regional Development Strategies: A Case Study Approach for Integrated Planning and Synthesis, in: Handbook of Transdisciplinary Research, 2008, S. 223-243. https://doi.org/10.1007/978-1-4020-6699-3_5.

16 Hendriksen u. a.: Participatory Decision Making for Sanitation Improvements in Unplanned Urban Settlements in East Africa, 2012, S. 98-119. https://doi.org/10.1177/1070496511426778.

17 Doncho Petkov u. a.: Mixing Multiple Criteria Decision Making with soft systems thinking techniques for decision support in complex situations, Decision Support Systems, 43 (2007) 4, S. 1615-1629. https://doi.org/10.1016/j.dss.2006.03.006; Ahti Salo. Salo, Raimo P. Hämäläinen: Multicriteria Decision Analysis in Group Decision Processes, in: D. Marc Kilgour \& Colin Eden (Hrsg.), Handbook of Group Decision and Negotiation, 2010, S. 269-283. https://doi.org/ 10.1007/978-90-481-9097-3_16; Lück, Nyga, 2018.

18 Laia Domènech, Hug March, David Saurí: Degrowth initiatives in the urban water sector? A social multi-criteria evaluation of non-conventional water alternatives in Metropolitan Barcelona, Journal of Cleaner Production, 38, 2013, S. 44-55. https://doi.org/10.1016/j.jclepro. 2011.09.020; Astrid Hendriksen u. a.: 2012; Rui Cunha Marques, Nuno Ferreira da Cruz, João Pires: Measuring the sustainability of urban water services, Environmental Science \& Policy, 54, 2015, S. 142-151; Ulrika Palme u. a.: Sustainable development indicators for wastewater systems - Researchers and indicator users in a co-operative case study, Resources, Conservation and Recycling, 43 (2005) 3, S. 293-311. https://doi.org/10.1016/j.resconrec.2004.06.006.

19 Judit Lienert u. a.: Structured decision-making for sustainable water infrastructure planning and four future scenarios, EURO Journal on Decision Processes, 2014. https://doi.org/10. 1007/s40070-014-0030-0; Lück, Nyga, 2018.

20 D. Marc Kilgour, Ye Chen, Keith W. Hipel: Multiple criteria approaches to group decision and negotiation, in: Matthias Ehrgott, José Rui Figueira, Salvatore Greco (Hrsg.), Trends in Multiple Criteria Decision Analysis. International Series in Operations Research \& Management Science, vol 142, Boston MA 2010, S. 317-338.

21 Chia-Cien Hsu, Brian A. Sandford: The Delphi Technique: Making Sense Of Consensus, Practical Assessment, Research \& Evaluation, 12 (2007) 10, S. 1-8.

22 Anna C. Jonsson u. a.: How participatory can participatory modelling be? Degrees of influence of stakeholder and expert perspectives in six dimensions of participatory modeling, Water Science and Technology, 56 (2007) 1, S. 207-214. https://doi.org/10.2166/wst.2007.453. 
Gruppendenken ${ }^{23}$ beobachtet. Insgesamt sind derartige MCDA-Entwicklungsprozesse anfällig für gruppendynamische Entwicklungen sowie Einflüsse der Moderation bei der Kommunikationssteuerung. ${ }^{24}$ Festzustellen bleibt, dass es eine Vielzahl von Methoden für den MCDA-Entwick-lungsprozess unter Einbindung der Interessengruppen gibt. Bisher dominieren jedoch Methoden ohne Softwareunterstützung, die zum Teil zu systematischen Verzerrungen des Ergebnisses führen können.

\subsection{Software-Unterstützung für partizipative MCDA}

Es gibt eine große Zahl von Softwarepaketen zur Unterstützung von MCDAWerkzeugen, die in mehreren Reviews systematisch untersucht wurden. ${ }^{25}$ Gleichfalls werden in der Literatur Fallstudien erwähnt, wie beispielsweise Korosuo u. a. (2011). ${ }^{26}$ Einige Entwicklungsprozesse von MCDA-Werkzeugen sind auf die Verwendung von Softwaretools abgestimmt, wie die Ansätze des Decision Analysis Interviews ${ }^{27}$ und des Decision Conferencing. ${ }^{28}$

Jyri Mustajoki und Mika Marttunen (2017) geben einen aktuellen Überblick über die Softwarepakete zur Unterstützung der MCDA-Entwicklung bezogen

23 Norbert L. Kerr, R. Scott Tindale: Group Performance and Decision Making, Annual Review of Psychology, 55 (2004) 1, S. 623-655. https://doi.org/10.1146/annurev.psych.55.090902.142009.

24 Raimo P. Hämäläinen, Jukka Luoma, Esa Saarinen: On the importance of behavioral operational research: The case of understanding and communicating about dynamic systems, European Journal of Operational Research, 228 (2013) 3, S. 623-634. https://doi.org/10.1016/j.ejor. 2013.02.001.

25 Vgl. Dennis M. Buede: Software review. Overview of the MCDA software market, Journal of Multi-Criteria Decision Analysis, 1 (1992) 1, S. 59-61; Dennis M. Buede: Second overview of the MCDA software market, Journal of Multi-Criteria Decision Analysis, 5 (1996) 4, S. 312-316; Vassil Vassilev, Krassimira Genova, Mariyana Vassileva: A brief survey of multicriteria decision making methods and software systems, Cybernetics and Information Technologies, 5 (2005) 1, S. 3-13; Alessio Ishizaka, Philippe Nemery: Multi-criteria decision analysis: methods and software, John Wiley \& Sons, 2013; Samantha Oleson: Decision analysis software survey, 2016; H. Roland Weistroffer, Yan Li: Multiple criteria decision analysis software, in: Salvatore Greco, Matthias Ehrgott, José Rui Figueira (Hrsg.), Multiple Criteria Decision Analysis. International Series in Operations Research \& Management Science. Bd. 233, 2016, S. 1301-1341.

26 Anu Korosuo u. a.: An integrated MCDA software application for forest planning: a case study in southwestern Sweden, International Journal of Mathematical and Computational Forestry \& Natural-Resource Sciences, 3 (2011) 2, S. 75-86.

27 Mika Marttunen, Raimo P. Hämäläinen: Decision analysis interviews in environmental impact assessment, European Journal of Operational Research, 87 (1995) 3, S. 551-563. https:// doi.org/10.1016/0377-2217(95)00229-4; Timo P. Karjalainen, Mika Marttunen, Simo Sarkki, Anne Mari Rytkönen: Integrating ecosystem services into environmental impact assessment: an analytic-deliberative approach, Environmental Impact Assessment Review, 40, 2013, S. 54-64.

28 Philipps, Bana E Costa, 2007. 
auf Umweltplanungsprozesse. ${ }^{29}$ Die meisten der untersuchten Softwarepakete unterstützen MCDA-bezogene Modelle und die Erhebung von Präferenzen über Fragebögen. Insbesondere bemerken sie, dass keines der untersuchten Softwarewerkzeuge ohne vorherige Erfahrung mit MCDA genutzt werden kann. Auch wird die direkte Entwicklung eines Zielsystems mit Hilfe einer großen Anzahl von Teilnehmenden durch keines der untersuchten Softwarepakete unterstützt.

Als eher typisch zu sehen ist die Fallstudie von Mika Marttunen u. a. (2015): Sie nutzen ein Softwarepaket, das im Rahmen von Interviews die Abfrage von Präferenzen der Interviewten unterstützt. Als problematisch sehen die Autoren, dass die softwarebasierte MCDA-Entwicklung Zeit und Engagement von Interessengruppen erfordert. Auch werden Probleme im Verständnis und der Akzeptanz der Methode gesehen, die die Unterstützung durch erfahrene MCDA-Entwicklerinnen und Enwickler erfordert. ${ }^{30}$

\subsection{Citizen Science}

Die Einbeziehung von Bürgerinnen und Bürger in Prozesse zur Wissensgewinnung ${ }^{31}$ ist auch unter dem Namen Citizen Science (CS) bekannt ${ }^{32}$ und Gegenstand wissenschaftlicher Forschung. ${ }^{33} \mathrm{Zu}$ den Aufgaben, die von den Bürgerinnen und Bürgern in CS-Prozessen übernommen werden, zählen u. a. Beobachten, Identifizieren, Klassifizieren, Analysieren und Fotografieren. ${ }^{34}$ Aktuelle Diskussionen zum möglichen Komplexitätsgrad von Aufgaben hin-

29 Jyri Mustajoki, Mika Marttunen: Comparison of multi-criteria decision analytical software for supporting environmental planning processes. Environmental Modelling and Software, 93, 2017, S. 78-91. https://doi.org/10.1016/j.envsoft.2017.02.026.

30 Marttunen u. a. 2015.

31 Rick Bonney, Caren B. Cooper, Janis Dickinson, Steve Kelling, Tina Phillips, Kenneth V. Rosenberg, Jennifer Shirk: Citizen Science: A Developing Tool for Expanding Science Knowledge and Scientific Literacy, BioScience, 59 (2009) 11, S. 977-984. https://doi.org/10.1525/bio.2009. 59.11.9.

32 Melissa V. Eitzel, u. a.: Citizen Science Terminology Matters: Exploring Key Terms, Citizen Science: Theory and Practice, 2(2917) 1. https://doi.org/10.5334/cstp.96.

33 Barbara Kieslinger u. a.: Evaluating citizen science: Towards an open framework, in: Citizen Science: Innovation in Open Science, Society and Policy, 2018. https://doi.org/10.17605/ OSF.IO/ENZC9; Danial Qaurooni u. a.: Citizens for Science and Science for Citizens, Proceedings of the 2016 CHI Conference on Human Factors in Computing Systems, 2016, S. 18221826. https://doi.org/10.1145/2858036.2858575; Andrea Wiggins, Kevin Crowston: From conservation to crowdsourcing: A typology of citizen science, Proceedings of the Annual Hawaii International Conference on System Sciences, 2011. https://doi.org/10.1109/HICSS.2011.207.

34 Andrea Wiggins, Kevin Crowston: Goals and Tasks: Two Typologies of Citizen Science Projects, 2012 45th Hawaii International Conference on System Sciences, 2012, S. 3426-3435. https://doi.org/10.1109/HICSS.2012.295. 
terfragen kritisch, dass eine Vielzahl von CS-Projekten Citizen Scientists eher mit einfachen Aufgaben betraut und diese nicht in die Forschungsprozesse selbst einbindet. Bürgerinnen und Bürger tragen damit vor allem zur Aufwandsreduzierung für die beteiligten, steuernden Wissenschaftlerinnen und Wissenschaftler bei. ${ }^{35}$ Mit Blick auf die genannten CS-Prozesse ist die Komplexität der Entwicklung eines MCDA-Werkzeuges als hoch zu bewerten. Jedoch wird gerade CS als ein Werkzeug gesehen, dass die Kopplung verschiedenartiger Systeme (hier: das zu bewertende System und das MCDA-Werkzeug als bewertendes System) ermöglicht. ${ }^{36}$ Die Funktionsfähigkeit vieler CS-Prozesse hängt stark von Softwarewerkzeugen zur Sammlung, Bearbeitung und Auswertung der Daten ab.

\subsection{Lösungsansatz}

Um den genannten Herausforderungen bisheriger partizipativer MCDAEntwicklungsprozesse zu begegnen, stellt dieser Artikel das Konzept einer web-basierten Softwareplattform als Grundlage der partizipativen Entwicklung von MCDA-Werkzeugen unter Einbeziehung aller Interessengruppen vor. Das wesentliche Kennzeichen ist die Nutzung kurzer, in sich geschlossener Interaktionen, sogenannter Elementarer Interaktionen (EI), zwischen den Teilnehmenden und der Plattform. Der Zugriff auf die Plattform über das Internet erlaubt eine örtliche flexible Teilnahme. Die zeitlich flexible Teilnahme ist durch die Asynchronität des Entwicklungsprozesses sichergestellt, d.h. die Teilnehmenden müssen nicht gleichzeitig aktiv sein. Darüber hinaus ist auch das zeitliche Engagement für den Entwicklungsprozess flexibel, d.h. das MCDA-Werkzeug kann, nachdem es einmal initiiert wurde, kontinuierlich weiterentwickelt werden. Die Plattform ermöglicht es einer großen Anzahl von Teilnehmenden, an der Entwicklung eines MCDA-Werkzeugs mitzuwirken. Die vorgeschlagene Plattform stellt sicher, dass nur die Initiierenden eines MCDA-Werkzeugs in der Bedienung der Plattform geschult werden müssen, während die Teilnehmer und Teilnehmerinnen lediglich selbsterklärende, grundlegende Interaktionen mit der Plattform durchführen. Sie brauchen kein tieferes Verständnis für die Entwicklung eines MCDA-Werkzeugs, die Plattform passt die durchzuführenden EIs an den Wissenstand der Teilnehmenden

35 Chiara Franzoni, Henry Sauermann: Crowd science: The organization of scientific research in open collaborative projects, Research Policy, 43 (2014) 1, S. 1-20. https://doi.org/10.1016/ j.respol.2013.07.005.

36 Rhiannon Crain, Caren Cooper, Janis L. Dickinson: Citizen Science: A Tool for Integrating Studies of Human and Natural Systems, Annual Review of Environment and Resources, 39(1), 2014, S. 641-665. https://doi.org/10.1146/annurev-environ-030713-154609. 
an. Die Interaktion mit der Plattform ist unmittelbar und wird daher nicht durch die Moderation beeinflusst. Die Beschreibung des Konzepts beschränkt sich auf die partizipative Erstellung eines Zielsystems als Kern eines MCDAWerkzeugs.

Dieser Artikel ist wie folgt aufgebaut: Im nächsten Abschnitt wird der Begriff der Elementaren Interaktion erläutert. Im darauffolgenden Abschnitt 3 werden Beispiele Elementarer Interaktionen zum Aufbau eines Zielsystems beschrieben. Das Konzept der geplanten Plattform wird in Abschnitt 4 beschrieben. Abschnitt 6 diskutiert die Implikationen, bevor der Artikel mit einer Zusammenfassung und dem Ausblick abgeschlossen wird.

\section{Elementare Interaktion}

Eine Elementare Interaktion (EI) ist definiert als kurze Interaktion der Teilnehmerin oder des Teilnehmers mit der Plattform. Im Idealfall handelt es sich bei einer EI um geschlossene Fragen, bei denen die Teilnehmerin oder der Teilnehmer aus einer Menge gegebener Antworten wählen muss. Eine EI ist in sich geschlossen und benötigt nur eine kurze Bearbeitungszeit, d.h. sie ist mit wenigen Klicks oder der Eingabe eines Begriffs in wenigen Sekunden abschließbar. Abbildung 3 zeigt Beispiele von EIs.

Wesentliches Entwurfsmerkmal für EIs ist - neben dem geringen zeitlichen Bearbeitungsaufwand - eine niedrige kognitive Komplexität, um einen niedrigschwelligen Zugang zur Plattform und damit zur Beteiligung am Entwicklungsprozess zu schaffen.

Eine Methode zur Begrenzung des Niveaus der kognitiven Komplexität ist die Verwendung von geschlossenen Fragen, wie zum Beispiel die Frage „Sind die Kriterien A oder B wichtiger, um das Teilziel C zu messen." (Diese Art von Frage ist bekannt als paarweiser Vergleich zur Bestimmung der Wichtungen im Rahmen des $\mathrm{AHP}^{37}$ ). Vorteil eines derartigen Designs sind kurze FeedbackZyklen: Eine Teilnehmerin oder ein Teilnehmer erhält eine kurze Aufgabe, die in wenigen Sekunde erledigt werden kann und für die das Feedback sofort erfolgt. Dies sollte die Teilnehmerin oder den Teilnehmer zur Beantwortung der nächsten EI verleiten, die ebenso einfach zu erreichen ist. Dieses Prinzip eines Stroms von EIs lässt sich beispielsweise in Umfragen der Firma Civey im

37 Saaty, 1990. 
Bereich der Meinungsforschung beobachten. ${ }^{38}$ Die Teilnehmenden können die Beantwortung elementarer Interaktionen jederzeit einstellen.

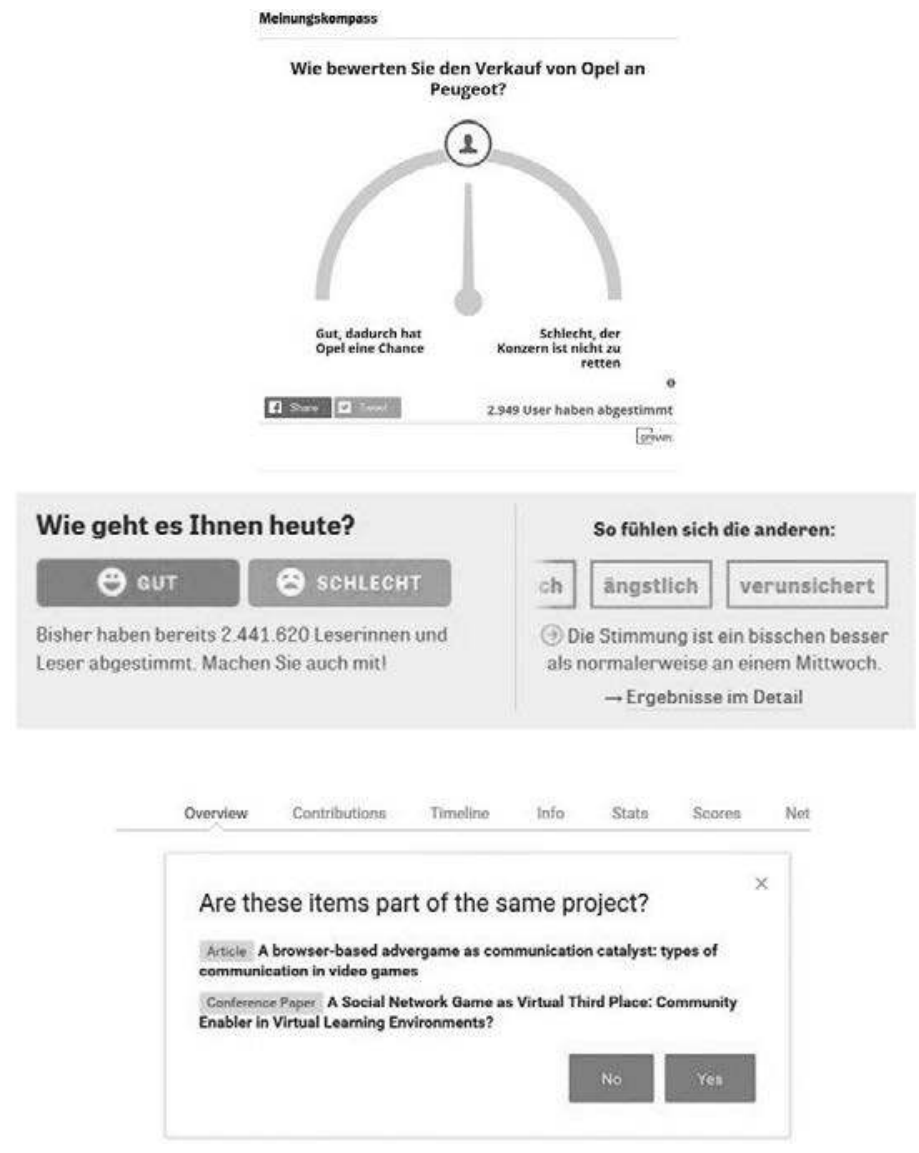

Abbildung 3: Beispiele für EIs: oben: Abfrage der Bewertung eines Firmenverkaufs durch die Leser eines Online-Magazins ${ }^{39}$, Mitte: Stimmungsabfrage für die Leser eines Online-Magazins ${ }^{40}$ unten: Assistent zur beiläufigen Gestaltung einer Online-Präsenz eines Sozialen Netzwerkes für Forscher. $^{41}$

38 Civey GmbH: Civey - Erfahre was Deutschland denkt. https://civey.com/ (letzter Zugriff: 21.06.2018); Dominik Wurnig: Das taugen die Umfragen von Civey, die dir gerade überall im Internet begegnen. Krautreporter, 2017, September 12.

39 Opinary GmbH: Opinary - Opinary makes opinions matter. http://opinary.com/ (letzter Zugriff: 17.03.2017); SPIEGEL ONLINE GmbH: Spiegel Online. http:// www.spiegel.de/ (letzter Zugriff: 22.03.2017).

40 ZEIT ONLINE GmbH: ZEIT ONLINE. https://www.zeit.de/ (letzter Zugriff: 23.01.2019).

41 ResearchGate GmbH: ResearchGate | Share and discover research. https://www.researchgate. net/ (letzter Zugriff: 22.03.2019). 


\section{Elementare Interaktionen zur Entwicklung eines Zielsystems}

Dieser Abschnitt stellt die zur Entwicklung eines Zielsystems notwendigen EIs vor. Die EIs sind in verschiedene Kategorien unterteilt, z.B. zum Erstellen, zur Strukturierung oder zur Validierung der Elemente eines Zielsystems. Im Folgenden werden die EIs nach Zweck kategorisiert und mit Hilfe von Beispielen beschrieben. Tabelle 1 stellt das Beschreibungsschema für die EIs bereit, jede Kategorie wird mit Hilfe eines Beispiels einer typischen EI illustriert.

Tabelle 1: Schema zur Beschreibung von EIs

\begin{tabular}{l|l} 
Schema Element & Beschreibung \\
\hline Id & Kennung der EI \\
\hline Name & Name der EI \\
\hline Beschreibung & Kontext und Zweck der EI \\
\hline Kategorie & $\begin{array}{l}\text { Die Kategorie beschreibt den Zweck der EI. Gewöhnlich gibt es } \\
\text { mehrere Els, um einen bestimmten Zweck zu erreichen, bei- } \\
\text { spielsweise um ein Zielsystem-Element zu validieren. }\end{array}$ \\
\hline Elemente & $\begin{array}{l}\text { Benennt die Elemente eines Zielsystems, die mit Hilfe der EI } \\
\text { bearbeitet werden können, wie z.B. Teilziel, Kriterium und } \\
\text { Indikator. }\end{array}$ \\
\hline Auswirkung & $\begin{array}{l}\text { Beschreibung der Wirkung der EI auf das Zielsystem. } \\
\text { Beschreibung eines Beispiels für die EI. }\end{array}$ \\
\hline Beispiel & $\begin{array}{l}\text { Beschreibung der notwendigen Interaktion zur Durchführung } \\
\text { der EI. }\end{array}$ \\
\hline Interaktion & \\
\hline
\end{tabular}

\subsection{El-Kategorie ,Elemente erstellen'}

Tabelle 2: Beschreibung der EI Nennen

\begin{tabular}{l|l}
\hline Id & 1 \\
\hline Name & Nennen \\
\hline Beschreibung & $\begin{array}{l}\text { Die EI wird benutzt, um neue Elemente für das Zielsystem zu } \\
\text { erfragen. Daher erfordert die EI das explizite Benennen eines } \\
\text { Elementes, d.h. die Antwort besteht aus mindestens einem } \\
\text { Wort. }\end{array}$ \\
\hline Kategorie & $\begin{array}{l}\text { Elemente erstellen } \\
\text { Teilziel, Kriterium, Indikator }\end{array}$ \\
\hline Elemente & $\begin{array}{l}\text { Erfragt ein neues Element des Modells. Im nächsten Schritt ist } \\
\text { das Element zu validieren. }\end{array}$ \\
\hline Beispiel & „Bitte nennen Sie ein Kriterium, das für die Beurteilung des \\
Teilziels Zeitaufwand wichtig ist.“ & Eingabe mindestens eines Wortes \\
\hline Interaktion & \\
\hline
\end{tabular}


Zunächst müssen die Teilnehmenden nach geeigneten Zielsystem-Elementen befragt werden. Dies wird durch die EI Nennen (Tabelle 2) erreicht, die beispielsweise fragt: „Bitte nennen Sie ein Kriterium, das für die Beurteilung des Teilziels ,Zeitaufwand' wichtig ist.“ Diese EI wird kognitiv als komplex angesehen, da die Teilnehmenden kreativ über einen geeigneten Begriff nachdenken müssen, der z.B. ein Kriterium bezeichnet. Zusätzlich muss der Begriff eingegeben werden, was aufwändiger ist, als zwischen zwei Alternativen zu wählen.

\subsection{El-Kategorie, Elemente validieren'}

Sobald ein Element benannt ist, muss es validiert werden. Dies ist das Ziel einer weiteren EI-Bestätigen (Tabelle 3): Die EI fragt, ob ein bestimmter, durch die EI-Kategorie ,Erstellen' gefundener Kandidat eines Zielsystem-Elements auch wirklich ein solcher ist. Beispiel ist die Frage: „Sind die direkten Kosten ein gültiges Kriterium zur Beurteilung der Wirtschaftlichkeit?“ Erreicht der Kandidat eines Zielsystem-Elements den Schwellenwert eines Validitätsmaßes, kann die Generierung von Zielsystem-Elementen in der direkt untergeordneten Hierarchiestufe des Zielsystems gestartet werden, z.B. wenn ein Kriterium validiert wurde, können geeignete Indikatoren generiert werden. Ein Maß für die Validität eines Zielsystems kann die Zustimmungsrate sein, d.h. der Quotient aus Zustimmungen und gesamten Antworten dieser EI bei einer Mindestanzahl von gesamten Antworten.

Tabelle 3: Beschreibung der EI Bestätigen

\begin{tabular}{|c|c|}
\hline Id & 2 \\
\hline Name & Bestätigen \\
\hline Beschreibung & $\begin{array}{l}\text { Die EI Bestätigen wird benutzt, um die Validität eines Elements durch } \\
\text { Bestätigung des Nutzers weiter zu erhöhen. }\end{array}$ \\
\hline Kategorie & Elemente validieren \\
\hline Elemente & Teilziel, Kriterium, Indikator \\
\hline Auswirkung & $\begin{array}{l}\text { Verändert die Validität eines Modells. Es werden solange EIs generiert, } \\
\text { bis das Element entweder bestätigt ist oder abgelehnt wird. }\end{array}$ \\
\hline Beispiel & $\begin{array}{l}\text { „Sind „Direkte Kosten` ein Kriterium, um das Teilziel ,Ökonomie` zu } \\
\text { bewerten?“ }\end{array}$ \\
\hline Interaktion & Auswahl: Ja/Nein-Entscheidung \\
\hline
\end{tabular}

In der Regel führt eine EI nie direkt zu einer Bewertung, sondern fließt in ein Validitätsmaß ein, d.h. nachdem eine bestimmte Menge von konsistenten Antworten gesammelt wurde, wird das Zielsystem weiterentwickelt. 


\subsection{El-Kategorie ,Strukturieren'}

Tabelle 4: Beschreibung der EI Duplikate identifizieren

\begin{tabular}{l|l}
\hline Id & 5 \\
\hline Name & Duplikate identifizieren \\
\hline Beschreibung & $\begin{array}{l}\text { Die EI dient zur Erkennung doppelter Elemente, die unterschiedliche } \\
\text { Namen haben mögen, aber semantisch dasselbe bezeichnen. }\end{array}$ \\
\hline Kategorie & Elemente strukturieren \\
\hline Elemente & Teilziel, Kriterium, Indikator \\
\hline Auswirkung & $\begin{array}{l}\text { Kann die Struktur eines Modells verändern. Wenn zwei Elemente als } \\
\text { Duplikat erkannt werden, entsteht daraus ein gemeinsames Element, } \\
\text { für das mit Hilfe einer weiteren EI ein Name gefunden werden muss. } \\
\text { Es werden solange EIs generiert, bis zwei Elemente entweder als Dup- } \\
\text { likat identifiziert werden können oder als Duplikat abgelehnt werden } \\
\text { können. }\end{array}$ \\
\hline Beispiel & $\begin{array}{l}\text { „Denken Sie, dass ,Indirekte Kosten` und ,Direkte Kosten` dasselbe } \\
\text { Kriterium des Teilziels,Ökonomie“ darstellen?“ } \\
\text { Alternative: „In welchem Ausmaß überlappen sich die Kriterien ,Di- } \\
\text { rekte Kosten“ und ,Indirekte Kosten“"? }\end{array}$ \\
\hline Interaktion & $\begin{array}{l}\text { Auswahl: Ja/Nein-Entscheidung } \\
\text { Alternative: Auswahl eines Wertes auf einer 0 - 100 \%-Skala }\end{array}$ \\
\hline
\end{tabular}

Ziel der Strukturierung von Zielsystem-Elementen, insbesondere von Teilzielen und Kriterien, ist die Identifizierung einer hierarchischen Struktur, als Nebenprodukt werden gleichfalls Duplikate eliminiert. Die EI Duplikate identifizieren (Tabelle 4) arbeitet mit zwei zufälligen Zielsystem-Elementen derselben Hierarchiestufe. Nach der Identifikation von Duplikaten wird mit Hilfe der EI Gemeinsamen Namen nennen ein gemeinsamer Name gefunden. Weitere EIs prüfen die Notwendigkeit einer Neustrukturierung der Hierarchie des Zielsystems. Mit Hilfe einer EI Übergeordnetes Element auswählen wird die aktuelle Zuordnung eines Elements (Kriterium oder Indikator) zu seinem übergeordneten Element in Frage gestellt, z.B. „Welchem Ziel sollte das Kriterium ,Direkte Kosten` zugeordnet werden: ,Wirtschaftliche Ziele‘, ,Umweltziele‘ oder ,Soziale Ziele?’”.

\subsection{El-Kategorie ,Elemente gewichten'}

Die Bestimmung von Gewichten priorisiert die Zielsystem-Elemente. Ein Beispiel ist der Paarvergleich, der durch die Verwendung von EI-Priorisierung paarweise durchgeführt wird, z.B. „Ist das Ziel ,Direkte Kosten' wichtiger als ,Indirekte Kosten'?" Eine Variante dieser EI ist die Angabe von mehr als zwei Antwortoptionen. Die EI Aus einer Menge auswählen (vgl. Tabelle 2, Id 4) 
bietet mehrere Antworten an: „Welche fünf der folgenden Kriterien sind die wichtigsten Kriterien für die Messung der ökologischen Ziele einer Reise?“.

Tabelle 5: Beschreibung der EI Mengenbasiert auswählen

\begin{tabular}{|c|c|}
\hline Id & 4 \\
\hline Name & Mengenbasiert auswählen \\
\hline Beschreibung & $\begin{array}{l}\text { Mit Hilfe dieser EI werden die relevantesten Elemente einer Menge } \\
\text { von Elementen ausgewählt. Die Auswahl kann geordnet oder unge- } \\
\text { ordnet sein. }\end{array}$ \\
\hline Kategorie & Elemente gewichten \\
\hline Elemente & Teilziel, Kriterium, Indikator \\
\hline Auswirkung & Erhöht die Validität von Elementen und gibt ihnen höheres Gewicht. \\
\hline Beispiel & $\begin{array}{l}\text { „Welche fünf der folgenden Kriterien sind die wichtigsten Kriterien } \\
\text { zur Beschreibung des Teilziels ,Ökonomie?" [Selektieren Sie bitte in } \\
\text { absteigender Wichtigkeit.]“ }\end{array}$ \\
\hline Interaktion & Auswahl aus einer Menge, bevorzugt über Drag\&Drop-Mechanismen \\
\hline
\end{tabular}

\section{Plattform-Konzept}

Die vorgeschlagene Plattform besteht aus sieben Elementen (siehe Abb. 3). Das Simulationsmodell (2) stellt ein System der realen Welt (1) dar. Basierend auf den Interaktionen der Teilnehmenden (3) mit der Plattform erstellt der Zielsystem-Manager (4) das Zielsystem inklusive der Wichtungen (5) mit Hilfe der Elementaren Interaktionen. Am Ende dient das Bewertungsergebnis (6) als Entscheidungsgrundlage (7).

(1) Das Bewertungsobjekt umfasst die Systemgrenzen und die Alternativen für das Bewertungsziel.

(2) Jedem Indikator des Zielsystems muss ein numerischer Wert zugeordnet werden, was entweder per Algorithmus oder mit einer manuellen Dateneingabe, z.B. im Falle einer Expertenbeurteilung, erfolgt. Die Eingabewerte zur Berechnung der Indikatorwerte werden im Simulationsmodell gespeichert, das ein Modell des zu bewertenden realen Systems darstellt. Ein Indikator ist daher von der Modellierung geeigneter Attribute im Simulationsmodell abhängig.

(3) Die Teilnehmenden sind für das Funktionieren der Plattform erforderlich. Sie werden durch den Benutzer-Manager (vgl. Abbildung 5) verwaltet.

(4) Der Zielsystem-Manager sammelt und aggregiert die Informationen, die per EI von den Teilnehmenden abgefragt werden.

(5) Das Zielsystem ergibt sich aus dem Bewertungsziel und dem Simulationsmodell. Beide Komponenten, ihre Wechselwirkungen und die Entwicklung eines Zielsystems werden in den Abschnitten 4.2 und 4.3 erläutert. 
(6) Die Kombination eines Zielsystems mit Wichtungen und den Beispieldaten des Simulationsmodells ergeben das Bewertungsergebnis.

(7) Auf der Grundlage der Bewertungsergebnisse kann eine Entscheidung getroffen werden.

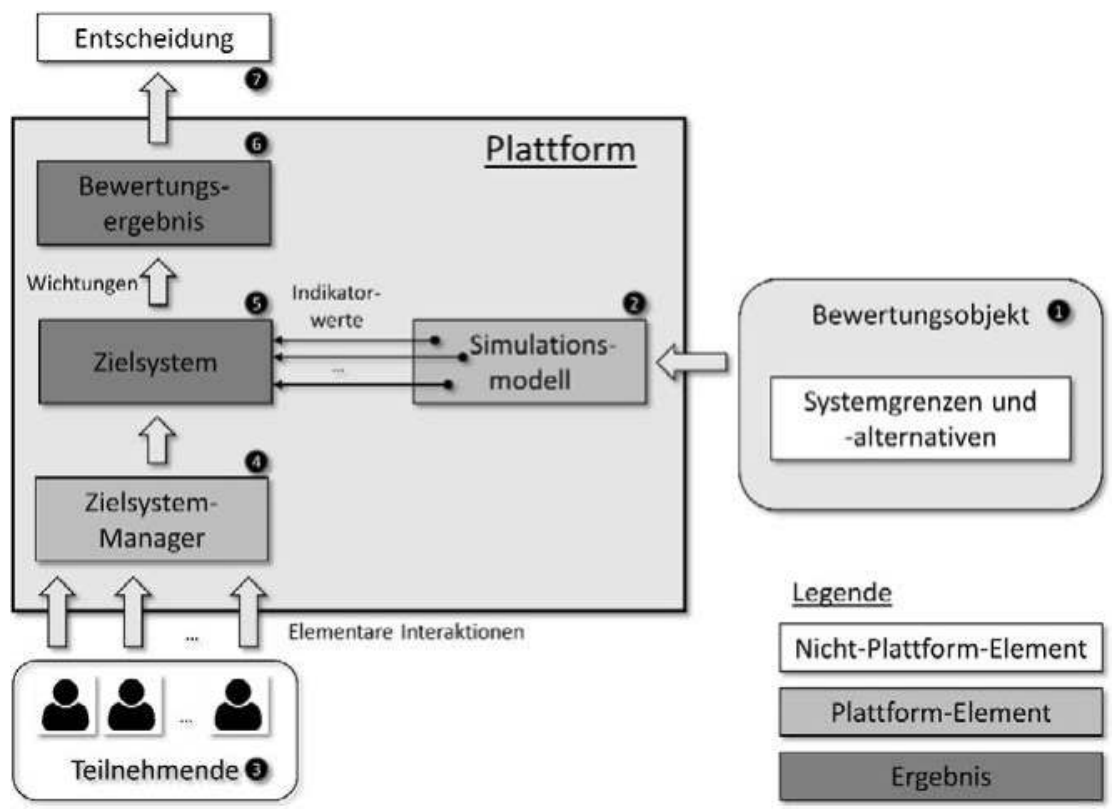

Abbildung 4: Systemarchitektur

\subsection{Use Case}

Der folgende Use Case zeigt die Schritte zur Erstellung eines Zielsystems eines MCDA-Werkzeugs zur Bewertung von technischer Wasserinfrastruktur, beispielsweise von Systemen zur Abwasserentsorgung wie Kläranlagen und Kanälen.

Schritt 1: Definition des Bewertungsziels, Auswahl und Aktivierung der Plattformteilnehmer. Eine oder mehrere Personen - die Initiatoren - erkennen die Notwendigkeit eines MCDA-Werkzeuges. Sie definieren das Ziel der Bewertung und die Systemgrenzen des zu bewertenden Systems. Darüber hinaus identifizieren die Initiatoren die betroffenen Interessengruppen.

Schritt 2: Starten des Entwicklungsprozesses. Sobald eine eingeladene Teilnehmerin oder ein eingeladener Teilnehmer ein Benutzerkonto auf der Plattform eröffnet, kann sie oder er sich über den Zweck des zu entwerfenden 
MCDA-Werkzeugs informieren. Während einer Einführung beantwortet die Teilnehmerin oder der Teilnehmer auch Multiple-Choice-Fragen, die die Intention der Teilnehmerin oder des Teilnehmers sowie deren themenbezogenen Wissensstand erfassen. Danach kann die Teilnehmerin oder der Teilnehmer durch das aktuelle Zielsystem blättern (das zu Beginn nur das Ziel umfasst). Alternativ kann die Teilnehmerin oder der Teilnehmer einen Strom von EIs beantworten, in deren Generierung der Wissensstand der Teilnehmerin oder des Teilnehmers einfließt. Die Teilnehmerin oder der Teilnehmer kann die Beantwortung von EIs jederzeit einstellen.

Schritt 3: Entwicklungsprozess. Der Entwicklungsprozess sollte in der Regel ohne die Notwendigkeit eines Administrations-Eingriffs ablaufen. Aufgaben, wie die Bewertung der Validität der vorgeschlagenen Elemente des Zielsystems und die Generierung des EI-Stroms, werden mit Hilfe von Algorithmen durchgeführt. Administratorinnen oder Administratoren müssen jedoch die Aktivitäten auf der Plattform überwachen, um auf Fehlersituationen, beispielsweise Teilnehmenden- oder Interaktionsmangel, reagieren zu können.

Schritt 4: Anwendung des Zielsystems. Nachdem ein Validitätsmaß für das Zielsystem einen Schwellenwert erreicht hat, kann die gefundene Version des Zielsystems als Meilensteinversion gekennzeichnet werden und in einem MCDA-Werkzeug genutzt werden.

Schritt 5: Evolution. Wenn sich die äußeren Bedingungen erheblich verändert haben (z.B. Präferenzen der Teilnehmenden), ist das entwickelte Zielsystem möglicherweise nicht mehr anwendbar. In diesem Fall kann die Plattform für eine Weiterentwicklung des Zielsystems auf Basis der letzten Meilensteinversion verwendet werden.

Die Schritte 1 bis 3 wurden im Rahmen einer Pilotstudie von Dennis Körting (2018) ${ }^{42}$ mit einem webbasierten Prototyp nachvollzogen. Dazu wurden die EIs mit Hilfe eines Fragenmoduls abgebildet und knapp 30 Teilnehmenden rundenbasiert jeweils zufällige EIs präsentiert. Das Modell des Zielsystems wurde manuell aus den Antworten abgeleitet und mit Hilfe einer Tabellenkalkulation aggregiert. Der jeweils aktuelle Stand des Zielsystems diente als Grundlage der elementaren Interaktionen der nächsten Runde. Die Pilotstudie zeigte die Funktionsfähigkeit der Plattform, gab jedoch auch Hinweise auf weiteren Arbeitsbedarf.

Im Folgenden werden spezifische Plattformkomponenten detaillierter beschrieben: Der Zielsystem-Manager, der Benutzer-Manager und der ModellAggregator.

42 Dennis Körting: Entwurf und Validierung eines Citizen Science- gestützten Verfahrens zur Entwicklung von multikritieriellen Bewertungssystemen am Beispiel technischer Infrastruktur, Bauhaus-Universität Weimar, 2018. 


\subsection{Zielsystem-Manager}

Der Zielsystem-Manager ermöglicht die Entwicklung eines operablen Zielsystems zusammen mit den Wichtungen. Abb. 4 zeigt Struktur und Arbeitsablauf des Zielsystem-Managers. Zentrale Komponente ist der EI-Strom-Generator, der EIs basierend auf verschiedenen Informationsquellen erzeugt. Zunächst wird das aktuelle Zielsystem auf fehlende Informationen analysiert. Wenn beispielsweise für ein Kriterium Indikatoren fehlen, werden bevorzugt EIs erzeugt, die zu Indikatoren für das betreffende Kriterium beitragen.

Eine weitere Informationsquelle ist der Benutzer-Manager, der jeder Teilnehmerin oder jedem Teilnehmer Wissensstände zuordnet. Wenn der Benutzer-Manager beispielsweise für eine Teilnehmerin oder einen Teilnehmer nur geringe technische Kompetenzen ausweist, sollten dieser Teilnehmerin oder diesem Teilnehmer weniger EIs zur Benennung fachspezifischer Kriterien angeboten werden, sondern mehr EIs zur Abfrage von Präferenzen.

Die EI-Antworten der Teilnehmenden werden an den Modell-Aggregator zur Integration in das Zielsystem weitergegeben. Der Modell-Aggregator benutzt auch ein vom Benutzer-Manager bereitgestelltes, benutzerspezifisches Kompetenzmodell.

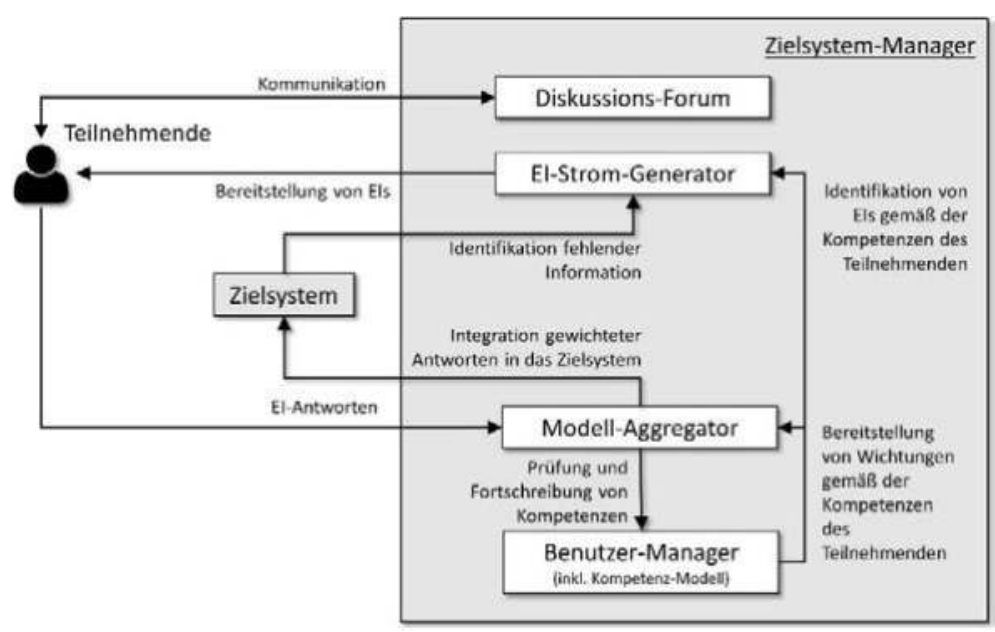

Abbildung 5: Zielsystem-Manager: Komponenten und Prozesse.

Eine weitere Komponente ist das Diskussionsforum. Ein solches Diskussionsforum kann mit Hilfe von Softwarepaketen wie MediaWiki (Wikimedia Foundation Inc. 2017) oder Stack Overflow (Stackoverflow.com 2012) realisiert 
werden. ${ }^{43}$ Ein Diskussionsforum wird über Hyperlinks in den ZielsystemManager integriert: Wenn ein Element in der grafischen Benutzeroberfläche erscheint, z.B. in einer EI, führt ein Hyperlink zur entsprechenden Beschreibungs- und Diskussionsseite dieses Zielsystem-Elements.

\subsection{Benutzer-Manager}

Im Allgemeinen beeinflussen verschiedene Interessengruppen den Designprozess eines MCDA-Systems. ${ }^{44}$ Beispielsweise können Interessengruppen wie Entscheidungstragende, Endanwendende, Expertinnen und Experten und Planende auftreten. ${ }^{45}$ Im Falle der vorgeschlagenen Plattform sind die Initiatoren eine eigenständige Gruppe im MCDA-Anwendungsdesignprozess. Die Initiatoren definieren das Ziel sowie die Systemgrenzen der MCDAAnwendung und laden potenzielle Teilnehmende ein. Sie stellen sicher, dass alle beteiligten Interessengruppen vertreten sind, d.h. dass die Gesamtheit der Teilnehmenden gleichzeitig Fachwissen und Präferenzen der betroffenen Interessengruppen bereitstellen kann. Darüber hinaus sind Endanwendende eine Interessengruppe. Endanwendende können als Interessengruppe ohne Fachkenntnisse über das Bewertungsobjekt, die von einer MCDA-Entscheidung betroffen sind, definiert werden. Endanwendende im Zusammenhang mit technischer Wasserinfrastruktur sind Bürgerinnen und Bürger.

Es ist notwendig, die Fähigkeiten jeder Teilnehmerin und jedes Teilnehmers zu beachten. So müssen beispielsweise die Beiträge einer ausgewiesenen Expertin oder eines ausgewiesenen Experten zu Elementen des Zielsystems stärker gewichtet werden als Annahmen der Endanwendenden. Daher wird während des Plattformbetriebs ein Kompetenzmodell erstellt und gepflegt. Das Kompetenzmodell wird verwendet, um die Antworten der EIs zu gewichten. Je mehr Fachwissen eine Teilnehmerin oder ein Teilnehmer vorweist, desto mehr Einfluss haben ihre oder seine Beiträge zu den Zielsystem-Elementen. Zu den möglichen Einflussfaktoren eines solchen Benutzermodells gehören:

43 Wikimedia Foundation Inc. 2017; Stackoverflow.com: Stack Overflow. http://stackoverflow. com/ (letzter Zugriff: 17.07.2017).

44 Banville u. a. 1998; Valentina Ferretti: From stakeholders analysis to cognitive mapping and Multi-Attribute Value Theory: An integrated approach for policy support, European Journal of Operational Research, 253 (2016) 2, S. 524-541. https://doi.org/10.1016/j.ejor.2016.02.054; Judit Lienert u. a.: Multiple-criteria decision analysis reveals high stakeholder preference to remove pharmaceuticals from hospital wastewater, Environmental Science and Technology, 45 (2011) 9, S. 3848-3857. https://doi.org/10.1021/es1031294; Lienert u. a.: Stakeholder analysis combined with social network analysis provides fine-grained insights into water infrastructure planning processes, 2013.

45 Lück, Nyga, 2018. 
Bewertungsergebnisse: Wenn sich eine Teilnehmerin oder ein Teilnehmer auf der Plattform anmeldet, wird ein Einführungstest zur Bewertung der technischen Kompetenz der Benutzerin oder des Benutzers durchgeführt. Initial sind entsprechende Fragen von den Initiatorinnen oder Initiatoren bereitzustellen, die dann während des Entwicklungsprozesses mit Hilfe eines kollaborativen Fragenentwurfs erweitert werden können. ${ }^{46}$

Selbstbeurteilung: Wenn sich eine Teilnehmerin oder ein Teilnehmer als Endanwenderin oder Endanwender ausweist, kann der anfängliche Schwerpunkt der EI auf dem Beitrag zu Präferenzen liegen.

Reputation: In Crowdsourcing-Systemen wird Teilnehmenden oft ein Attribut Reputation zugewiesen. ${ }^{47}$ Reputation ist ein Maß für die Qualität der bisherigen Beiträge einer Teilnehmerin oder eines Teilnehmers zum System. Gleichzeitig wird die Reputation genutzt, um Systemberechtigungen abzuleiten. Ein Beispiel ist die Frage- und Antwortsoftware Stack Overflow. ${ }^{48}$

\subsection{Modell-Aggregator}

Kennzeichnend für die Plattform ist der kontinuierliche Entwicklungsprozess: Während das MCDA-Werkzeug bereits in der Lage ist, ein Bewertungsergebnis zu liefern, kann das Zielsystem weiterentwickelt werden. Es ist festzulegen, wann das Zielsystem als stabil angesehen werden kann. Dazu wird vorgeschlagen, verschiedene Attribute einzuführen, die jeweils ein Validitätsmaß eines Zielsystemelements beschreiben. Beispiele derartiger Validitätsmaße sind die Attribute

- validityAttribute, das die Validität des Elements selbst beschreibt, d.h. die Zustimmung der Teilnehmenden für die Existenz der Elemente,

- validityStructure, das die Validität der strukturellen Position des Elements beschreibt, d.h. die Zustimmung der Teilnehmenden für die richtige Position des Elements im Zielsystem, und

- validityChildren, das ein Maß für die Stabilität der untergeordneten Elemente darstellt, z.B. wenn diese Elemente eine vollständige Menge definieren und voneinander unabhängig sind.

46 Stephen McClean: Implementing PeerWise to engage students in collaborative learning, Perspectives on Pedagogy and Practice, 6, 2015, S. 89-96.

47 B. Thomas Adler, Luca De Alfaro, Santiago M. Mola-Velasco, Paolo Rosso, Andrew G.West: Wikipedia vandalism detection: Combining natural language, metadata, and reputation features, Lecture Notes in Computer Science (Including Subseries Lecture Notes in Artificial Intelligence and Lecture Notes in Bioinformatics), 6609 LNCS(PART 2), 2011, S. 277-288. https://doi.org/10.1007/978-3-642-19437-5_23.

48 Stackoverflow.com: Stack Overflow. http://stackoverflow.com/ (letzter Zugriff: 17.07.2012). 
Die Werte der gültigkeitsbeschreibenden Attribute werden von EIs kontinuierlich aktualisiert, was sich auf die zugehörigen Elemente auswirkt. Wenn beispielsweise mehrere Benutzende dieselben Kriterien über die EI benennen (z.B. ,direkte Kosten'), wird die Gültigkeit des Elements (dargestellt durch das Attribut validityAttribute) jeweils erhöht. Die Bestätigung eines Elements (EI Bestätigen) erhöht den Wert von validityAttribute, während eine Ablehnung den Wert verringert.

Die Frage der Validität stellt sich auf (mindestens) drei Ebenen. Die erste Ebene sind die Zielsystem-Elemente: Die Gültigkeit eines Elements wird durch das Attribut validityAttribute angezeigt. Die nächste Ebene sind die Gruppen von untergeordneten Elementen eines übergeordneten Elements, z.B. die Kriterien, die zu einem Teilziel gehören. Das Attribut validityStructure steigt, wenn EIs der Kategorie Strukturieren keine Änderungen bewirken: Beispielsweise erhöht jede Negation der EI Duplikate identifizieren (Tabelle 4) die Gültigkeit, jede Bestätigung verringert sie erneut. Außerdem tragen die Werte für die Attribute validityStructure der Kinder zum Attribut validityChildren des übergeordneten Elements bei. Die dritte Ebene sind die Prozessstufen: Es gibt zwei Prozessstufen - die erste ist die Hierarchie der Teilziele, Kriterien und Indikatoren, die zweite ist durch die Wichtung der Teilziele und Kriterien gegeben. Die Bestimmung der Wichtungen ist nur dann sinnvoll, wenn die zugrundeliegende erste Stufe in einer Meilensteinversion erfasst wurde, d.h. nicht mehr verändert wird. Die Entscheidung, wann eine Meilensteinversion vorliegt, kann von der Plattform automatisch mit Hilfe der Validitätsmaße getroffen werden.

\section{Diskussion}

Die beschriebene Plattform ermöglicht die Entwicklung von Zielsystemen für MCDA-Werkzeuge für beliebige Anwendungszwecke. Die Plattform kann öffentlich bereitgestellt werden und bereits etablierte Methoden der MCDA, wie Wichtungsbestimmung und Transferfunktionen integrieren.

Es gibt bereits strukturierte Kommunikationstechniken wie die DelphiMethode $^{49}$, die darauf abzielen, negative Gruppeneffekte durch den Einsatz wiederholter Fragebögen zu reduzieren. Das vorgeschlagene Konzept betont jedoch asynchrone Aktivitäten, automatisierte Aggregation der Antworten und die Einbeziehung aller Interessengruppen ohne die Notwendigkeit von persönlichen Treffen.

49 Chia-Cien Hsu, Brian A. Sandford: The Delphi Technique: Making Sense Of Consensus, 2007. 
Citizen Science (CS) stellt einen vielversprechenden Anwendungskontext einer solchen Plattform zur Zielsystementwicklung dar. Obwohl der Begriff CS nicht klar definiert ist ${ }^{50}$, werden zwei Kennzeichen für CS immer wieder genannt. Erstens ist CS offen für eine große Anzahl potenzieller Teilnehmender und zweitens werden Informationen offen zur Verfügung gestellt (Franzoni und Sauermann 2014). ${ }^{51}$ Neben den kleinteiligen Aufgaben ist die zeitliche Unabhängigkeit ein wichtiges Merkmal von CS-Prozessen. In vielen CSProjekten beschäftigen sich die Teilnehmenden überwiegend mit einfachen Aufgaben wie der Erhebung von Daten oder der Dokumentation von Beobachtungen. ${ }^{52}$ In wenigen CS-Projekten sind komplexere Aufgaben zu beobachten. ${ }^{53}$ Wie sich in einer Pilotstudie gezeigt hat, stellt die Entwicklung eines Zielsystems teilweise hohe Anforderungen an die Teilnehmenden, die bei der Gestaltung eines passenden CS-Prozesses berücksichtigt werden müssen. Eine häufige Herausforderung bei CS-Projekten sind möglicher Vandalismus und Inhaltsmanipulation - es wurden Gegenmaßnahmen vorgeschlagen. ${ }^{54}$ In der hier dargestellten MCDA-Entwicklung können Manipulationsversuche von Einzelnen beispielsweise über Valididätsmaße oder Kompetenzmodellanalysen verhindert werden. Die Hauptmotivation für die Abbildung von MCDAEntwicklung auf einen CS-Prozess ist nicht die Nutzung ungenutzter Arbeitskapazitäten zur Senkung der Kosten wissenschaftlicher Ergebnisse wie Sauermann und Franzoni (2015) postulieren. ${ }^{55}$ Vielmehr kann CS hier als Mittel betrachtet werden, um die Komplexität des MCDA-Entwicklungsprozesses auf ein operables Niveau zu reduzieren. Während bei der konventionellen MCDAEntwicklung an vielen Stellen komplexe menschliche Fähigkeiten gefordert sind - beispielsweise Intuition bei der Identifikation von Kriterien - und die erfolgreiche Erstellung eines MCDA-Werkzeuges vom Engagement einiger weniger Hauptakteurinnen und Hauptakteure abhängt, verteilt der CS-Ansatz

50 Melissa V. Eitzel u. a.: Citizen Science Terminology Matters: Exploring Key Terms, 2017; Christopher Kullenberg, Dick Kasperowski: What is citizen science? - A scientometric meta-analysis, PLoS ONE, 11 (2016) 1, S. 1-16. https://doi.org/10.1371/journal.pone.0147152.

51 Chiara Franzoni, Henry Sauermann: Crowd science: The organization of scientific research in open collaborative projects, 2014, S. 1-20. https://doi.org/10.1016/j.respol.2013.07.005.

52 Andrea Wiggins, Kevin Crowston: Goals and Tasks, 2012.

53 Marketa Dolejšová, Denisa Kera: Soylent Diet Self-Experimentation: Design Challenges in Extreme Citizen Science Projects. Proceedings of the 2017 ACM Conference on Computer Supported Cooperative Work and Social Computing, 2017, S. 2112-2123. https://doi.org/ $10.1145 / 2998181.2998365$.

54 Adler u. a. 2011.

55 Henry Sauermann, Chiara. Franzoni: Crowd science user contribution patterns and their implications, Proceedings of the National Academy of Sciences of the United States of America, 112 (2015) 3, S. 679-684. https://doi.org/10.1073/pnas.1408907112. 
die Entwicklungslast auf viele Schultern und reduziert die Komplexität für die Akteure auf die sequentielle Bearbeitung elementarer Interaktionen.

Die Plattform erfordert eine große Anzahl von Teilnehmenden, wie die Pilotstudie zeigte. Für CS-Projekte wurde festgestellt, dass die Nutzeraktivität mit der Zeit abnimmt. ${ }^{56}$ Daher müssen die Teilnehmenden immer wieder neue Motivationsreize erhalten. Die Plattform sollte daher um Methoden des Motivationsdesigns für die Teilnehmenden ergänzt werden. Gamification, die Anwendung von Spielprinzipien auf reale Aufgaben ${ }^{57}$, ist eine Methode zur Förderung der Motivation und des Engagements der Teilnehmenden. Es wird erwartet, dass die Plattform mehrere Möglichkeiten bietet, Gamification zu integrieren: Die Plattform erzeugt eine große Menge an Nutzungsdaten, z.B. die Anzahl der Interaktionen einer jeden Benutzerin oder eines jeden Benutzers oder die Anzahl der aufeinanderfolgenden Tage von Logins. Insbesondere die Einführung eines Reputationssystems wird als Motivationsreiz angesehen, ohne die Ergebnisse der Teilnehmenden negativ zu beeinflussen. ${ }^{58}$ Auch unmittelbare Rückmeldung wird als wichtig zur Förderung des Engagements angesehen ${ }^{59}$ und kann durch eine umfangreiche Statistikkomponente abgebildet werden, die die Auswirkungen einer durchgeführten EI visualisiert. Kennzahlen wie „EI pro Teilnehmerin oder Teilnehmer“ und „EI aller Teilnehmenden in den letzten 24 Stunden " sind für einen Teil der Teilnehmenden motivierend.

Im Allgemeinen ermöglicht die Plattform Visualisierungen, da eine Vielzahl visualisierbarer Informationen in der Plattform vorhanden ist. Visualisierungen gelten als vorteilhaft für die kognitive Verarbeitung von Informationen, insbesondere in Kombination mit Interaktionen. ${ }^{60} \mathrm{Um}$ die Ergebnisse von MCDA-Werkzeugen zu visualisieren, gibt es bereits verschiedene Ansätze,

56 Henry Sauermann u. a. 2015.

57 Sebastian Deterding u. a.: From game design elements to gamefulness: defining gamification. Proceedings of the 15th International Academic MindTrek Conference: Envisioning Future Media Environments, 2011, S. 9-15.

58 Sarah-Kristin Thiel: Reward-based vs. Social Gamification, Proceedings of the 9th Nordic Conference on Human-Computer Interaction - NordiCHI '16, (January), 2016, S. 1-6. https://doi.org/10.1145/2971485.2996739; Sarah-Kristin Thiel, Peter Fröhlich: Gamification as Motivation to Engage in Location-Based Public Participation? in: Progress in Location-Based Services 2016, 2018. https://doi.org/10.1007/978-3-319-47289-8_20.

59 Rosemary Garris, Robert Ahlers, James E. Driskell: Games, Motivation, and Learning: A Research and Practice Model, Simulation Gaming, 33 (2002) 4, S. 441-467.

60 Zhicheng Liu, John Stasko: Mental models, visual reasoning and interaction in information visualization: A top-down perspective, IEEE Transactions on Visualization \& Computer Graphics, (2010) 6, S. 999-1008. 
insbesondere der Vergleich verschiedener Varianten von Diagrammen. ${ }^{61}$ Derartige Ansätze können innerhalb der Plattform durch die Integration von Kennzahlen über die Zeit, beispielsweise der Entwicklung von Benutzerinnenund Benutzerpräferenzen, ergänzt werden.

Neben der Entwicklung von MCDA-Werkzeugen zur konkreten Anwendung scheint die Plattform auch als Lernwerkzeug in didaktischen Kontexten geeignet: Für die Erstellung eines MCDA-Werkzeuges ist eine weitreichende Auseinandersetzung mit dem Bewertungsobjekt notwendig. Ausgelöst durch die stattfindende Reflektion ist auch von Lernprozessen auszugehen. ${ }^{62}$

\section{Zusammenfassung}

Die Entwicklung von MCDA-Werkzeugen ist ein komplexer Prozess, der hohen organisatorischen Aufwand erfordert. Dieser Artikel beschreibt eine Plattform für die Entwicklung von Zielsystemen, die essentielle Bestandteile von MCDA-Werkzeugen sind. Kernparadigma ist die Nutzung von sogenannten Elementaren Interaktionen (EIs). Basierend auf den Informationen, die durch diese elementaren Interaktionen gesammelt werden, entwickelt sich im Laufe der Zeit ein Zielsystem bestehend aus Teilzielen, Kriterien und Indikatoren. Relevante Komponenten der Plattform sind der Benutzer-Manager, der für jede Teilnehmerin und für jeden Teilnehmer ein Kompetenzmodell verwaltet; ein Modell-Aggregator, der die durch elementare Interaktionen erhaltenen Antworten in das Zielsystem transformiert; ein Zielsystem-Manager, der Ströme elementarer Interaktionen erzeugt und ein Diskussionsforum zur Förderung der Kommunikation zwischen den Teilnehmenden. Eine Pilotstudie bestätigte die Funktionsfähigkeit des Konzepts. Es trat weiterer Entwicklungsbedarf zu Tage, wie z.B. die Festlegung von Methoden zur Clusterung von Kriterien, die Teilzielen zugeordnet sind, sowie die Reduktion der kognitiven Komplexität elementarer Interaktionen.

Im Gegensatz zu konventionellen Verfahren zur Entwicklung von MCDAAnsätzen, die zumeist geprägt sind von der Zusammenarbeit von wenigen Expertinnen und Experten, erlaubt der vorgestellte Ansatz die Zusammenarbeit vieler heterogener Teilnehmender, deren Beiträge über Kompetenzmodelle gesteuert werden. Die Kompetenzen der Teilnehmenden können mit dem

61 Arto Haara u. a.: Use of interactive data visualization in multi-objective forest planning, Journal of Environmental Management, 210 (2018), S. 71-86. https://doi.org/10.1016/j.jenvman.2018. 01.002

62 Heinrich Söbke, Andrea Lück, Steffi Zander: Plattform zur Entwicklung multikriterieller Bewertungssysteme als Medium partizipativen, forschenden Lernens, BEWEGUNGEN - DGfE Kongress 2018, 18.-21. März, Universität Duisburg-Essen. 
Bewertungssystem wachsen, Bürgerinnen und Bürger können sich schrittweise zu Experten entwickeln.

Zusammenfassend sind die folgenden Vorteile der Plattform festzuhalten: (1) Die Plattform steht jeder MCDA-Anwendungsdomäne offen, (2) sie arbeitet mit geringem Verwaltungsaufwand, (3) sie senkt den organisatorischen Aufwand für die Entwicklung eines Zielsystems, (4) sie unterstützt die Weiterentwicklung eines bestehenden Zielsystems bei wesentlichen Änderungen der äußeren Bedingungen und (5) sie ermöglicht die digitale Dokumentation des Entwicklungsprozesses eines Zielsystems - und damit dessen Reproduzierbarkeit. Die Reproduzierbarkeit kann sich positiv auf die Akzeptanz von MCDAWerkzeugen auswirken. Insbesondere mit der Nutzung elementarer Interaktionen erscheint die Plattform als geeignetes Medium für Citizen Sciencebasierte Ansätze zur Entwicklung von MCDA-Werkzeugen und ist damit eine deutliche qualitative Erweiterung der Methodenvielfalt zur Erstellung von MCDA-Werkzeugen.

\section{Literaturverzeichnis}

B. Thomas Adler u. a.: Wikipedia vandalism detection: Combining natural language, metadata, and reputation features, Lecture Notes in Computer Science (Including Subseries Lecture Notes in Artificial Intelligence and Lecture Notes in Bioinformatics), 6609 LNCS(PART 2), 2011, S. 277-288. https://doi.org/10.1007/978-3-642-19437-5_23.

Paula Antunes u. a.: Participatory multi-criteria analysis of irrigation management alternatives: the case of the Caia irrigation district, Portugal, International Journal of Agricultural Sustainability, 9 (2011) 2, S. 334-349. https://doi.org/10.1080/14735903.2011.582358.

Claude Banville u. a.: A stakeholder approach to MCDA, Systems Research and Behavioral Science, 15 (1998) 1, S. 15-32.

Valerie Belton, Theodor J. Stewart: Multiple Criteria Decision Analysis - An Integrated Approach, 2002. https://doi.org/10.1007/978-1-4615-1495-4.

Rick Bonney u. a.: Citizen Science: A Developing Tool for Expanding Science Knowledge and Scientific Literacy, BioScience, 59 (2009) 11, S. 977-984. https://doi.org/10.1525/bio.2009. 59.11.9.

Dennis M. Buede: Software review. Overview of the MCDA software market, Journal of Multi-Criteria Decision Analysis, 1 (1992) 1, S. 59-61.

Dennis M. Buede: Second overview of the MCDA software market, Journal of Multi-Criteria Decision Analysis, 5 (1996) 4, S. 312-316.

Civey GmbH: Civey - Erfahre was Deutschland denkt. https://civey.com/.

Rhiannon Crain, Caren Cooper, Janis L. Dickinson: Citizen Science: A Tool for Integrating Studies of Human and Natural Systems, Annual Review of Environment and Resources, 39 (2014) 1, S. 641-665. https://doi.org/10.1146/annurev-environ-030713-154609. 
Sebastian Deterding u. a.: From game design elements to gamefulness: defining gamification. Proceedings of the 15th International Academic MindTrek Conference: Envisioning Future Media Environments, 2011, S. 9-15.

Marketa Dolejšová, Denisa Kera: Soylent Diet Self-Experimentation: Design Challenges in Extreme Citizen Science Projects. Proceedings of the 2017 ACM Conference on Computer Supported Cooperative Work and Social Computing, 2017, S. 2112-2123. https://doi.org/10.1145/2998181.2998365.

Laia Domènech, Hug March, David Saurí: Degrowth initiatives in the urban water sector? A social multi-criteria evaluation of non-conventional water alternatives in Metropolitan Barcelona, Journal of Cleaner Production, 38 (2013), S. 44-55. https://doi.org/10.1016/ j.jclepro.2011.09.020.

Melissa V. Eitzel u. a.: Citizen Science Terminology Matters: Exploring Key Terms, Citizen Science: Theory and Practice, 2 (2017) 1. https://doi.org/10.5334/cstp.96.

Valentina Ferretti: From stakeholders analysis to cognitive mapping and Multi-Attribute Value Theory: An integrated approach for policy support, European Journal of Operational Research, 253 (2016) 2, S. 524-541. https://doi.org/10.1016/j.ejor.2016.02.054.

Chiara Franzoni, Henry Sauermann: Crowd science: The organization of scientific research in open collaborative projects, Research Policy, 43 (2014) 1, S. 1-20. https://doi.org/ 10.1016/j.respol.2013.07.005.

Rosemary Garris, Robert Ahlers, James E. Driskell: Games, Motivation, and Learning: A Research and Practice Model, Simulation Gaming, 33 (2002) 4, S. 441-467.

Robin Gregory u. a.: Structured Decision Making: A Practical Guide to Environmental Management Choices, Wiley-Blackwell, 2012.

Arto Haara u. a.: Use of interactive data visualization in multi-objective forest planning, Journal of Environmental Management, 210 (2018), S. 71-86. https://doi.org/10.1016/ j.jenvman.2018.01.002.

Raimo P. Hämäläinen, Jukka Luoma, Esa Saarinen: On the importance of behavioral operational research: The case of understanding and communicating about dynamic systems, European Journal of Operational Research, 228 (2013) 3, S. 623-634. https://doi.org/ 10.1016/j.ejor.2013.02.001.

Astrid Hendriksen u. a.: Participatory Decision Making for Sanitation Improvements in Unplanned Urban Settlements in East Africa, Journal of Environment and Development, 21 (2012) 1, S. 98-119. https://doi.org/10.1177/1070496511426778.

Lukas Hermwille: The role of narratives in socio-technical transitions-Fukushima and the energy regimes of Japan, Germany, and the United Kingdom, Energy Research \& Social Science, 11 (2016), S. 237-246. https://doi.org/10.1016/j.erss.2015.11.001.

Chia-Cien Hsu, Brian A. Sandford: The Delphi Technique: Making Sense Of Consensus, Practical Assessment, Research \& Evaluation, 12 (2007) 10 , S. 1-8.

Alessio Ishizaka, Philippe Nemery: Multi-criteria decision analysis: methods and software, John Wiley \& Sons, 2013.

Anna C. Jonsson u. a.: How participatory can participatory modelling be? Degrees of influence of stakeholder and expert perspectives in six dimensions of participatory modeling, Water Science and Technology, 56 (2007) 1, S. 207-214. https://doi.org/10.2166/ wst.2007.453. 
Timo P. Karjalainen u. a.: Integrating ecosystem services into environmental impact assessment: an analytic-deliberative approach, Environmental Impact Assessment Review, 40 (2013), S. 54-64.

Ralph L. Keeney: Value-focused thinking. A path to creative decisionmaking, (überarb. Auflage). Harvard University Press, 1996.

Norbert L. Kerr, R. Scott Tindale: Group Performance and Decision Making, Annual Review of Psychology, 55 (2004) 1, S. 623-655. https://doi.org/10.1146/annurev.psych.55.090902. 142009.

Barbara Kieslinger u. a.: Evaluating citizen science: Towards an open framework, in: Citizen Science: Innovation in Open Science, Society and Policy, 2018. https://doi.org/10.17605/ OSF.IO/ENZC9.

D. Marc Kilgour, Ye Chen, Keith W. Hipel: Multiple criteria approaches to group decision and negotiation, in Matthias Ehrgott, José Rui Figueira, Salvatore Greco (Hrsg.), Trends in Multiple Criteria Decision Analysis. International Series in Operations Research \& Management Science, vol 142, Boston MA 2010, S. 317-338.

Anu Korosuo u. a.: An integrated MCDA software application for forest planning: a case study in southwestern Sweden, International Journal of Mathematical and Computational Forestry \& Natural-Resource Sciences, 3 (2011) 2, S. 75-86.

Dennis Körting: Entwurf und Validierung eines Citizen Science- gestützten Verfahrens zur Entwicklung von multikritieriellen Bewertungssystemen am Beispiel technischer Infrastruktur, Bauhaus-Universität Weimar, 2018.

Christopher Kullenberg, Dick Kasperowski: What is citizen science? - A scientometric metaanalysis, PLoS ONE, 11 (2016) 1, S. 1-16. https://doi.org/10.1371/journal.pone.0147152.

Risto Lahdelma, Pekka Salminen, Joonas Hokkanen: Using multicriteria methods in environmental planning and management, Environmental Management, 26(6), 2000, S. 595-605.

Judit Lienert u. a.: Multiple-criteria decision analysis reveals high stakeholder preference to remove pharmaceuticals from hospital wastewater, Environmental Science and Technology, 45 (2011) 9, S. 3848-3857. https://doi.org/10.1021/es1031294.

Judit Lienert, Florian Schnetzer, Karin Ingold: Stakeholder analysis combined with social network analysis provides fine-grained insights into water infrastructure planning processes, Journal of Environmental Management, 125 (2013), S. 134-148. https://doi.org/ DOI 10.1016/j.jenvman.2013.03.052.

Judit Lienert u. a.: Structured decision-making for sustainable water infrastructure planning and four future scenarios, EURO Journal on Decision Processes, 2014. https://doi.org/ 10.1007/s40070-014-0030-0.

Zhicheng Liu, John Stasko: Mental models, visual reasoning and interaction in information visualization: A top-down perspective, IEEE Transactions on Visualization \& Computer Graphics, (2010) 6, S. 999-1008.

Andrea Lück, Ilka Nyga: Experiences of stakeholder participation in multi-criteria decision analysis (MCDA) processes for water infrastructure, Urban Water Journal, 15 (2018) 6, S. 508-517. https://doi.org/10.1080/1573062X.2017.1364394.

Cathy Macharis, Astrid De Witte, Jeroen Ampe: The multi-actor, multi-criteria analysis methodology (MAMCA) for the evaluation of transport projects: Theory and practice, Journal of Advanced Transportation, 2009. https://doi.org/10.1002/atr.5670430206. 
Rui Cunha Marques, Nuno Ferreira da Cruz, João Pires: Measuring the sustainability of urban water services, Environmental Science \& Policy, 54 (2015), S. 142-151.

Mika Marttunen, Raimo P. Hämäläinen: Decision analysis interviews in environmental impact assessment, European Journal of Operational Research, 87 (1995) 3, S. 551-563. https://doi.org/10.1016/0377-2217(95)00229-4.

Mika Marttunen u. a.: How to design and realize participation of stakeholders in MCDA processes? A framework for selecting an appropriate approach, EURO Journal on Decision Processes, 3 (2015) 1-2, S. 187-214. https://doi.org/10.1007/s40070-013-0016-3.

Stephen McClean: Implementing PeerWise to engage students in collaborative learning, Perspectives on Pedagogy and Practice, 6 (2015), S. 89-96.

Jyri Mustajoki, Mika Marttunen: Comparison of multi-criteria decision analytical software for supporting environmental planning processes. Environmental Modelling and Software, 93 (2017), S. 78-91. https://doi.org/10.1016/j.envsoft.2017.02.026.

Ilka Nyga u. a.: Rahmenkonzepte zur integrierten Bewertung siedlungswasserwirtschaftlicher Systeme, Gwf-Wasser|Abwasser, (2018) 1, S. 53-62.

Samantha Oleson,: Decision analysis software survey, 2016.

Opinary GmbH: Opinary - Opinary makes opinions matter. http://opinary.com/.

Ulrika Palme u. a.: Sustainable development indicators for wastewater systems - Researchers and indicator users in a co-operative case study, Resources, Conservation and Recycling, 43 (2005) 3, S. 293-311. https://doi.org/10.1016/j.resconrec.2004.06.006.

Doncho Petkov u. a.: Mixing Multiple Criteria Decision Making with soft systems thinking techniques for decision support in complex situations, Decision Support Systems, 43 (2007) 4, S. 1615-1629. https://doi.org/10.1016/j.dss.2006.03.006.

Lawrence D. Philipps, C. Bana E Costa: Transparent prioritisation, budgeting and resource allocation with multi-criteria decision analysis and decision conferencing, Annals of Operations Research, 154 (2007) 1, S. 51-68. https://doi.org/10.1007/s10479-007-0183-3.

Danial Qaurooni u. a.: Citizens for Science and Science for Citizens, Proceedings of the 2016 CHI Conference on Human Factors in Computing Systems, 2016, S. 1822-1826. https://doi.org/10.1145/2858036.2858575.

Ortwin Renn, Jonathan Paul Marshall: Coal, nuclear and renewable energy policies in Germany: From the 1950s to the ,Energiewende`, Energy Policy, 99 (2016), S. 224-232. https://doi.org/10.1016/j.enpol.2016.05.004.

ResearchGate GmbH: ResearchGate | Share and discover research.

Thomas L. Saaty: How to make a decision: The analytic hierarchy process, Desicion Making by the Analytic Hierarchy Process: Theory and Applications, 48 (1990) 1, S. 9-26. http://doi.org/10.1016/0377-2217(90)90057-I.

Ahti Salo, Raimo P. Hämäläinen: Multicriteria Decision Analysis in Group Decision Processes, in: D. Marc Kilgour, Colin Eden (Hrsg.), Handbook of Group Decision and Negotiation, 2010, S. 269-283. https://doi.org/10.1007/978-90-481-9097-3_16.

Henry Sauermann, Chiara. Franzoni: Crowd science user contribution patterns and their implications, Proceedings of the National Academy of Sciences of the United States of America, 112 (2015) 3, S. 679-684. https://doi.org/10.1073/pnas.1408907112.

Heinrich Söbke, Andrea Lück, Steffi Zander: Plattform zur Entwicklung multikriterieller Bewertungssysteme als Medium partizipativen, forschenden Lernens, BEWEGUNGEN DGfE Kongress 2018, 18.-21. März, Universität Duisburg-Essen. 
Stackoverflow.com: Stack Overflow. http://stackoverflow.com/.

Sarah-Kristin Thiel: Reward-based vs. Social Gamification, Proceedings of the 9th Nordic Conference on Human-Computer Interaction - NordiCHI '16, (January), 2016, S. 1-6. https://doi.org/10.1145/2971485.2996739.

Sarah-Kristin Thiel, Peter Fröhlich: Gamification as Motivation to Engage in Location-Based Public Participation ? in: Progress in Location-Based Services 2016, 2018. https://doi.org/ 10.1007/978-3-319-47289-8_20.

Vassil Vassilev, Krassimira Genova, Mariyana Vassileva: A brief survey of multicriteria decision making methods and software systems, Cybernetics and Information Technologies, 5 (2005) 1, S. 3-13.

Alexander I. Walter, Armin Wiek, Roland W. Scholz: Constructing Regional Development Strategies: A Case Study Approach for Integrated Planning and Synthesis, in: Handbook of Transdisciplinary Research, 2008, S. 223-243. https://doi.org/10.1007/978-1-40206699-3_5.

H. Roland Weistroffer, Yan Li: Multiple criteria decision analysis software, in: S. Greco, M. Ehrgott, J. Figueira (Hrsg.), Multiple Criteria Decision Analysis. International Series in Operations Research \& Management Science. Bd. 233, 2016, S. 1301-1341.

Andrea Wiggins, Kevin Crowston: From conservation to crowdsourcing: A typology of citizen science, Proceedings of the Annual Hawaii International Conference on System Sciences, 2011. https://doi.org/10.1109/HICSS.2011.207

Andrea Wiggins, Kevin Crowston: Goals and Tasks: Two Typologies of Citizen Science Projects, 2012 45th Hawaii International Conference on System Sciences, 2012, S. 34263435. https://doi.org/10.1109/HICSS.2012.295

Dominik Wurnig: Das taugen die Umfragen von Civey, die dir gerade überall im Internet begegnen. Krautreporter. https://krautreporter.de/2077-das-taugen-die-umfragen-voncivey-die-dir-gerade-uberall-im-internet-begegnen.

ZEIT ONLINE GmbH: ZEIT ONLINE. https://www.zeit.de/. 


\section{Berichte und Mitteilungen}


Open-Access-Publikation im Sinne der CC-Lizenz BY-SA 4.0 ๑ 2020 , Vandenhoeck \& Ruprecht GmbH \& Co. KG, Göttingen ISBN Print: 9783847111771 - ISBN E-Lib: 9783737011778 
Hendrikje Carius

\section{Virtuelle Ausstellungen. Konzepte, Praxis und Perspektiven. Bericht zu einer Tagungs- und Workshopreihe}

\section{Einleitung}

Mit dem Aufbau digitaler Sammlungen in Bibliotheken, Archiven und Museen und dem Einsatz digitaler Technologien haben sich vielfältige Ansätze zur Sichtbarmachung dieser Sammlungen und ihrer Objekte herausgebildet. Virtuelle Ausstellungen haben dabei in den letzten Jahren als komplementäres Mittel zur Präsentation, Inszenierung und Vermittlung von Themen, digitalen Exponaten und Sammlungen zunehmend an Bedeutung gewonnen. Sie bieten potenziell dauerhafte orts- und zeitunabhängige, multiperspektivische Zugänge zu Objekten, tiefere Kontextualisierungen und Visualisierungen sowie globale, spartenübergreifende Vernetzungen von Inhalten. Methoden und Ansätze der Digital Humanities, Mixed Reality, Storytelling, Public History oder Gamification können diese Möglichkeiten entscheidend erweitern. Virtuelle Ausstellungen befinden sich jedoch noch in einer Phase, in der es vielfältige Begriffsbestimmungen gibt, sich Standards erst ansatzweise herausbilden und wissenschaftlich-methodische Reflexionen zum Medium ein Desiderat sind. Die Forschungsbibliothek Gotha veranstaltet daher zusammen mit dem Netzwerk für digitale Geisteswissenschaften und Citizen Science an der Universität Erfurt seit 2017 eine Tagungs- und Workshopreihe zur digitalen Ausstellungskuratierung und damit verbundener Aspekte wie digitaler Wissenschaftskommunikation oder digitales Storytelling. 


\section{Workshop "Virtuelle Ausstellungen in Bibliotheken. Konzepte, Praxis und Perspektiven" (2017)}

Der erste, vom 7. bis 8. September 2017 in Gotha veranstaltete Workshop zielte unter dem Titel „Virtuelle Ausstellungen in Bibliotheken. Konzepte, Praxis und Perspektiven“ darauf, den aktuellen Stand zu bündeln, Ansätze und Perspektiven zu diskutieren, den fachübergreifenden Austausch zu befördern und somit die Basis für eine zukünftig verstärkte Vernetzung zu legen. ${ }^{1}$ Der dreiteilig angelegte Workshop bot in einer einführenden Sektion einen Überblick über das breite Spektrum an aktuellen Definitionen, Formaten und Konzepten (Katja Selmikeit). Michael Müller machte darüber hinaus in seinem Beitrag deutlich, dass das Medium virtuelle Ausstellung in der digitalen Kulturlandschaft zwar inzwischen etabliert sei, aber noch oft das Spezifische des Expositorischen verfehle. Angesichts des mangelnden Ereignischarakters und fehlender räumlicher Aspekte plädierte er für die Ausnutzung medienspezifischer Potentiale im digitalen Raum. Ausgehend von der (linguistischen) Multimodalitätsforschung, die die verschiedenen semiotischen Ressourcen eines multimodalen Texts oder Artefakts betrachtet, nahm Martin Siefkes das Zusammenwirken einzelner Ressourcen wie Text und Bild, Videos, interaktive Grafiken und Virtual Reality-Elementen bei virtuellen Ausstellungen als einem ,multimodalen Genre' in den Blick. Ein weiterer Themenbereich widmete sich dem Aspekt der Informationsvisualisierung sowie Virtual Reality-Ansätzen. Alexander Kulik beleuchtete dabei konzeptionelle und technische Grundlagen für die gemeinsame Exploration und Analyse von 3D-Datensätzen in virtueller Realität. Die dritte Sektion widmete sich institutionenübergreifenden sowie institutionellen Plattformen, die zum Teil exemplarisch anhand von bestehenden oder in der Konzeptionsphase befindlichen Ausstellungen vorgestellt und diskutiert wurden. Florian Sepp gab einen Einblick in das für die breite Öffentlichkeit konzipierte Ausstellungsmodul des Bayerischen Kulturportals bavarikon. ${ }^{2}$ Für die Präsentation der virtuellen Jahresausstellungen kooperiert die Bayerische Staatsbibliothek zudem mit Google Arts \& Culture ${ }^{3}$, die Christian Eidloth vorstellte. Lisa Landes präsentierte mit DDBstudio der Deutschen Digitalen Bibliothek ein weiteres templateorientiertes, nachnutzbares Angebot zur Erstellung und Veröffentlichung von eigenen virtuelle Ausstellungen. ${ }^{4}$ Einen

1 Vgl. die Homepage der Veranstaltung: https://blog-fbg.uni-erfurt.de/2017/07/workshop-virt uelle-ausstellungen-in-bibliotheken-konzepte-praxis-und-perspektiven/ (letzter Zugriff: 08.02. 2020).

2 https://www.bavarikon.de (letzter Zugriff: 08.02.2020).

3 https://artsandculture.google.com/partner/bavarian-state-library (letzter Zugriff: 08.02.2020).

4 https://pro.deutsche-digitale-bibliothek.de/ddbstudio (letzter Zugriff: 08.02.2020). 
anderen Ansatz machte Sylvia Asmus u. a. anhand von Künste im Exil nachvollziehbar. ${ }^{5}$ Das kooperative Projekt unter der Federführung des Deutschen Exilarchivs 1933-1945 der Deutschen Nationalbibliothek (DNB) ist als kontinuierlich erweiterbare Digital-Only-Ausstellung angelegt. Stephanie Jacobs präsentierte für das Deutsche Buch- und Schriftmuseum der DNB in Leipzig die Strategien eines medienwissenschaftlich arbeitenden Museums anhand der 2012 eröffneten Dauerausstellung Zeichen - Bücher - Netze. Von der Keilschrift zum Binärcode, die als hybride Ausstellung konzipiert ist. ${ }^{6}$ Hendrikje Carius und Carsten Resch stellten außerdem das im Zusammenspiel von Bibliothek und Softwareentwicklung in der konzeptionellen Phase befindliche Ausstellungsportal der Forschungsbibliothek Gotha vor. Das Vorhaben ist Teil der digitalen Strategie der Bibliothek mit dem Ziel einer dauerhaften, interoperablen und nachnutzbaren Infrastruktur für virtuelle Ausstellungen, die zusammen mit der Thüringer Universitäts- und Landesbibliothek Jena und der Jenaer Agentur für Informationsästhetik JustOrange realisiert wird.

Insgesamt führte der Workshop die Spannungsfelder zusammen, in denen sich das Medium virtuelle Ausstellung bewegt: Dazu gehört im Kontext der Begriffsdefinition und Abgrenzung der Umgang mit der Ausstellungstradition, d.h. der Spannung zwischen dem Ansatz, das neue Medium unter Bezug zur Ausstellungstradition zu entwickeln und dem Ansatz, das virtuelle Ausstellen von dieser Traditionslinie stärker zu entkoppeln und medienspezifisch neu zu denken. Die unterschiedlich bewertete Gewichtung exponat first / content matters versus exchange / event matters blieb vor dem Hintergrund format- und themenspezifischer Logiken der verschiedenen Ausstellungen auch in der Diskussion offen. Breiten Konsens traf der Befund, dass die Entwicklung und Professionalisierung des Formats durch gezielte Benutzerforschung und Usability Studien untersetzt werden müssten. Mit Blick auf Nachhaltigkeitsstrategien wurden offene Standards für eine stärkere (spartenübergreifende) Interoperabilität zwischen virtuellen Ausstellungen und anderen digitalen Infrastrukturen sowie die Limitierung von cutting edge-Technologien thematisiert, um den Wartungsaufwand und perspektivische Migrationen minimal zu halten. Deutlich gezeigt hat sich, dass insbesondere die Spannung zwischen Normierung und Standardisierung, generischen Infrastrukturen und Erlebnischarakter oder auch Fragen der Sichtbarmachung der wissenschaftlichen Forschung in virtuellen Ausstellungen weiterer Diskussionen bedarf. Mit dem Workshop, der die Notwendigkeit eines praxisorientierten, von wissenschaftlich-methodischen Reflexionen begleiteten Austauschforums zum Themenfeld sichtbar gemacht hat, ist eine systematische Debatte zu einem noch in der Entwicklung befindli-

5 http://kuenste-im-exil.de (letzter Zugriff: 08.02.2020).

6 http://mediengeschichte.dnb.de/DBSMZBN/Web/DE/Home/ (letzter Zugriff: 08.02.2020). 
chen Medium angeregt worden, die mit einem spartenübergreifenden Nachfolgeworkshop fortgeführt werden sollte.

\section{Tagungs-Workshop „Exponat - Raum - Interaktion. Perspektiven für das Kuratieren digitaler Ausstellungen" (2018)}

Der Tagungs-Workshop „Exponat - Raum - Interaktion. Perspektiven für das Kuratieren digitaler Ausstellungen“"wurde vom 9. bis 10. November 2018 in Kooperation mit der Professur für Museologie an der Universität Würzburg durchgeführt. ${ }^{7}$ Die gemeinsame Zusammenarbeit ist der Überzeugung entsprungen, dass ein interdisziplinärer Austausch zwischen den Fachdisziplinen und den einzelnen Akteuren von Ausstellungsgestaltungen bei der spartenübergreifenden Weiterentwicklung des Mediums essenziell ist, um digitale Potenziale und Synergien nutzen zu können - auch wenn dabei immer auch institutionelle Logiken und spartenspezifische Formatierungen zu bedenken sind. Die Tagung gab neben Inputvorträgen im Plenum in Workshops Raum für disziplinübergreifenden Austausch zu den Fragestellungen der einzelnen Sektionen. Hendrikje Carius und Guido Fackler führten zunächst aus bibliotheks- und museumswissenschaftlicher Perspektive in das Thema ein. Fackler stellte dabei ausgehend vom museologischen Paradigmenwechsel sein Konzept des Digital Educurating vor, bei dem sich Kuratieren und Vermitteln unter Einsatz von Möglichkeiten des digitalen Raums verbinden. In der ersten Sektion zum Themenfeld ,Exponat' richtete sich der Blick auf das Objekt und dessen Rolle sowie spezifische Qualität als digitales Exponat. Swantje Dogunke näherte sich der Thematik aus Sicht der Digital Humanities, wobei sie zwischen nur im digitalen Medium existenten digitalen Exponaten (z.B. Tools zur Datenvisualisierung) und digitalisierten Exponaten (digitale Repräsentationen physischer Objekte) unterschied und virtuelle Ausstellungen als Zusammenspiel von Daten, digitalisierten und digitalen Exponaten sowie zentralem Content betrachtete. Mark Fichtner widmete sich der semantischen Repräsentation von Museumsobjekten am Beispiel der virtuellen Forschungsumgebung WissKI, die z.B. zur Vorbereitung virtueller Ausstellungen eingesetzt werden kann. Der multimedialen Ausstellungsgestaltung zur Generierung besonderer Erlebnishorizonte in physischen Ausstellungen widmete sich Eva Hornecker.

7 Vgl. die Homepage der Veranstaltung: https://blog-fbg.uni-erfurt.de/2018/08/exponat-rauminteraktion-perspektiven-fuer-das-kuratieren-digitaler-ausstellungen/. Siehe auch den Tagungsbericht von Berthold Kreß zu: Exponat - Raum - Interaktion. Perspektiven für das Kuratieren digitaler Ausstellungen, 09.11.2018 - 10.11.2018 Gotha, in: H-Soz-Kult, 26.05.2019. www.hsozkult.de/conferencereport/id/tagungsberichte-8292 (letzter Zugriff: 08.02.2020). 
Ebenfalls in der Sektion zur multimedialen Ausstellungsgestaltung im digitalen Raum zeigten Viktoria Brüggemann und Mark-Jan Bludau interaktive Sammlungsvisualisierungen mit explorativen Zugriffsmöglichkeiten, insbesondere mit dem durch den an der Fachhochschule Potsdam entwickelten VIKUSViewer. Ein weiterer Themenbereich des Workshops widmet sich unter Einbezug von Erkenntnissen aus der musealen Publikumsforschung den Erwartungen der Rezipienten im Digitalen. Werner Schweibenz plädierte für eine systematische Online-Besucherforschung, um ein optimales Interaktionsdesign und eine verbesserte Suchunterstützung zu ermöglichen. Henning Meyer stellte aus Sicht eines Ausstellungsgestalters konzeptionelle Ansätze in der Arbeitspraxis vor, die physische Ausstellungen mit digitaler Technologie verbinden. Die abschließende Sektion thematisierte digitale Strategien und Vermittlungskonzepte bei virtuellen Ausstellungen, die sich auf Interaktion und aktiven Einbezug des Publikums richten. Bastian Schlang stellte mit Gamification ein neues Paradigma in der Ausstellungskonzeption vor, das zu Besucherzentrierung und Handlungsorientierung führe. Tine Nowak widmete sich partizipativen Ansätzen in der digitalen Kulturvermittlung, in der Kuratoren und Besucher zusammenarbeiten.

Hinsichtlich der konzeptionellen Ausrichtung virtueller Ausstellungen gingen die Tendenzen in den Diskussionen des Tagungs-Workshops insgesamt hin zur Verzahnung physischer mit digitalen Ansätzen, d.h. hin zu hybriden Angeboten und Mixed-Reality-Ansätzen. Prämisse ist dabei Media follows Content, d.h. die multimedialen Entwicklungen müssen unmittelbar an den inhaltlichen Kontext angebunden sein. Die Notwendigkeit zur weiteren Verständigung über grundlegende Begrifflichkeiten über den Ausstellungsbegriff hinaus (z.B. Objekt, digitalisiertes bzw. digitales Exponat, digitale Sammlung) hat sich gerade bei dem interdisziplinären Austausch gezeigt. Der TagungsWorkshop machte einmal mehr deutlich, dass dabei eine enge Kooperation von Fachwissenschaft, Bibliothek, Museum, Gestaltung und Informatik sowohl bei der Fassung des Mediums virtuelle Ausstellung als auch bei den strukturellen Herausforderungen (Infrastrukturen, Nachhaltigkeit, Interoperabilität) von zentraler Bedeutung ist.

Die Publikation der Tagungsbeiträge beider Veranstaltungen ist als zweiter Band in der Reihe DHICS. Eine Schriftenreihe des Netzwerks für digitale Geisteswissenschaften und Citizen Science geplant. 
Open-Access-Publikation im Sinne der CC-Lizenz BY-SA 4.0 ๑ 2020 , Vandenhoeck \& Ruprecht GmbH \& Co. KG, Göttingen ISBN Print: 9783847111771 - ISBN E-Lib: 9783737011778 


\section{Das Frontend als ,Flaschenhals'? Mediävistische Ressourcen im World Wide Web und ihre Nutzungspotentiale für eine Digitale Prosopographie. (19.-21.02.2020, Friedrich-Schiller- Universität Jena)}

\section{Tagungsbericht}

Die gemeinsam vom Lehrstuhl für Mittelalterliche Geschichte der FSU Jena (PD Dr. Robert Gramsch-Stehfest), der Arbeitsgruppe Künstliche Intelligenz an der FSU Jena (Dr. Christian Knüpfer, Clemens Beck, M.A.) sowie der Professur für Mittelalterliche Geschichte der Universität Erfurt (Dr. Christian Oertel) ausgerichtete Tagung stellte sich zur Aufgabe, die Perspektiven der Nutzerinnen und Nutzer mediävistischer Online-Repositorien mit denen ihrer Anbieter zusammenzubringen. Dies wurde vor allem in den ersten beiden Sektionen „Heuristik und Kritik im digitalen Zeitalter. Digitale Quelleneditionen und ihre Nutzung in der aktuellen mediävistischen Forschung" sowie „Nutzungspotentiale mediävistischer Online-Ressourcen für eine ,Digitale Prosopographie' gelehrter Eliten des Spätmittelalters“ umgesetzt.

In diesen zwei Sektionen wurden zunächst eine Reihe von OnlineQuellenrepositorien vorgestellt, deren Vor- und Nachteile im jeweils folgenden Vortrag aus der Nutzerperspektive beurteilt wurden. Auf diese Weise wurden das Portal Monasterium.net (Georg Vogeler/ Magdalena Weileder), die Regesta Imperii online (Andreas Kuczera/Clemens Beck) und das Repertorium Germanicum online (Jörg Voigt und Jörg Hörnschemeyer/Alexander Maul) vorgestellt und analysiert. Ergänzt wurden die drei Vorträge durch die Vorstellung der Planungen für die Regesta Bohemiae et Moraviae aetatis Hussiticae durch Robert Novotný, für die (naturgemäß) noch keine Nutzerperspektive präsentiert werden konnte sowie durch die Vorstellungen von Forschungsergebnissen, die Gustavo Riva auf der Grundlage des Portals Handschriftencensus erzielen konnte. Auf die Präsentation dieses Portals wurde aufgrund seines technisch veralteten Standes verzichtet. Am Schluss der zweiten Sektion wurden 
drei online-Portale vorgestellt, die die Angebote der bisher thematisierten Quellenrepositorien ergänzen und entweder als Normdatenquellen in diese eingebunden werden können (GND) oder als online-Datenbanken bereits erzielte prosopographische Forschungsergebnisse nutzbar machen (Germania Sacra online, Neue Deutsche Biographie online).

Die dritte und letzte Sektion „Mediävistische Prosopographie zwischen traditioneller Quellenarbeit, Internet-Ressourcen und Citizen Science. Die Vision digital unterstützten Forschens" fokussierte auf den Umgang der mediävistisch Forschenden mit den aus den online-Angeboten gewonnen Informationen. Die hier dargebotenen Beiträge beschäftigten sich mit den Möglichkeiten kollaborativen Arbeitens in der Mediävistik (Horst Enzensberger, René Smolarski, Olaf Simons), der semi-automatischen Überführung von Informationen aus online-Angeboten in die jeweils eigene Forschungs-Datenbank (Robert Gramsch-Stehfest/Christian Knüpfer) sowie mit den Möglichkeiten und Notwendigkeiten des Forschungsdatenmanagements (Thomas Mutschler) und der Digitalisierung (Jan Keupp). Abgeschlossen wurde die Tagung durch eine Round-Table-Diskussion (Jörg Feuchter, Robert Gramsch-Stehfest, Torsten Hiltmann, Daphné Kerremans, Christoph Kudella, Jörg Voigt), an der sich alle Anwesenden aktiv beteiligen konnten (und dies auch taten).

Sowohl in den Diskussionen zu den einzelnen Vorträgen als auch besonders in der Round-Table-Diskussion zeigte sich, dass sowohl die Anwenderinnen und Anwender als auch die Anbieter der Repositorien gern die Gelegenheit zum Gespräch wahrnahmen. Erstere brachten ihre Nutzungswünsche und Verbesserungsvorschläge vor, letztere stellten ihre Angebote vor, mussten aber auch bisweilen auf ihre (technisch und personell) begrenzten Möglichkeiten hinweisen. Als besonders problematisch auf Seiten der Anbieter stellte sich die Pflege (z.B. Regestierung von Urkunden, Annotierung, Identifikation und Auszeichnung von Orts- und Personendaten) bereits vorhandener Angebote heraus, da für derartige strukturelle Aufgaben keine Drittmittel bereitgestellt würden. Auf der anderen Seite hätte viele der online-Angebote keine oder nur lockere Anbindungen an Universitäten und daher ebenso wenig Zugriff auf Haushaltsmittel.

Einen weiteren Schwerpunkt der Diskussionen stellte die Frage dar, welche digitalen Kompetenzen die historisch Forschenden aufweisen sollten, um einerseits selbst derartige Angebote nutzen, andererseits aber auch den (unvermeidlichen) Prozess der Digitalisierung kritisch begleiten zu können. Letzteres sei notwendig, um die erreichten wissenschaftlichen Standards des Fachs auch in der digitalen Welt aufrecht zu erhalten. Ein Beispiel, in dem dies (gerade noch) gelungen sei, lieferte Johannes Preiser-Kapeller im öffentlichen Abendvortrag, in dem er die Venice Time Machine thematisierte, ein Großprojekt, 
das mit fragwürdigen Methoden der Quantifizierung aus vergangenen Ereignissen Voraussagen für die Zukunft errechnen wollte, letztendlich aber doch keine Förderung als europäisches Flagship-Projekt erhielt.

Zur Frage der notwendigen Kompetenzen von Historikerinnen und Historiker herrschte Einigkeit darüber, dass die Forderung Emmanuels Le Roy Ladurie aus dem Jahr 1968 „Der Historiker von morgen wird Programmierer sein oder nicht mehr sein!" heute aufgrund der Benutzerfreundlichkeit digitaler Angebote nicht mehr unterstützt werden müsse. Darüber, welche Kompetenzen gefordert werden müssten, waren aber durchaus verschiedene Auffassungen vertreten. So setzte etwa die Anlage des die Tagung eröffnenden Vortrags von Georg Vogeler bereits ein hohes Maß an technisch-informatischem Wissen voraus und endete mit der Forderung, dass nicht (nur) das Frontend einer Überarbeitung bedürfe, sondern dass Schnittstellen - über die Programme direkt kommunizieren - besser auf die Bedürfnisse der Benutzerinnen und Benutzer zugeschnitten werden müssten. Das würde natürlich die Kompetenz auf Seiten der Forschenden erfordern, derartige Schnittstellen benutzen zu können. In einer ähnlichen Richtung äußerte sich Christoph Kudella in einem Diskussionsbeitrag, in dem er das Erlernen einer Abfragesprache für Datenbanken als von den Forschenden erwartbar kennzeichnete. Eher relativierend wies hingegen in der abschließenden Diskussion der Informatiker Clemens Beckstein der Informatik die Aufgabe zu, Lösungen bereitzustellen, die keine Spezialfähigkeiten von den Nutzerinnen und Nutzer erwarten dürften. 
Open-Access-Publikation im Sinne der CC-Lizenz BY-SA 4.0 ๑ 2020 , Vandenhoeck \& Ruprecht GmbH \& Co. KG, Göttingen ISBN Print: 9783847111771 - ISBN E-Lib: 9783737011778 


\section{Oliver Bräckel}

\section{Nachruf Patrick Pfeil (17.09.1980-23.12.2019)}

Mit Trauer nehmen wir Abschied von unserem langjährigen Kollegen und Freund Patrick Pfeil, der am 23. Dezember 2019 nach kurzer schwerer Krankheit verstorben ist. Über viele Jahre war er ein prägendes Mitglied im Netzwerk für digitale Geisteswissenschaften.

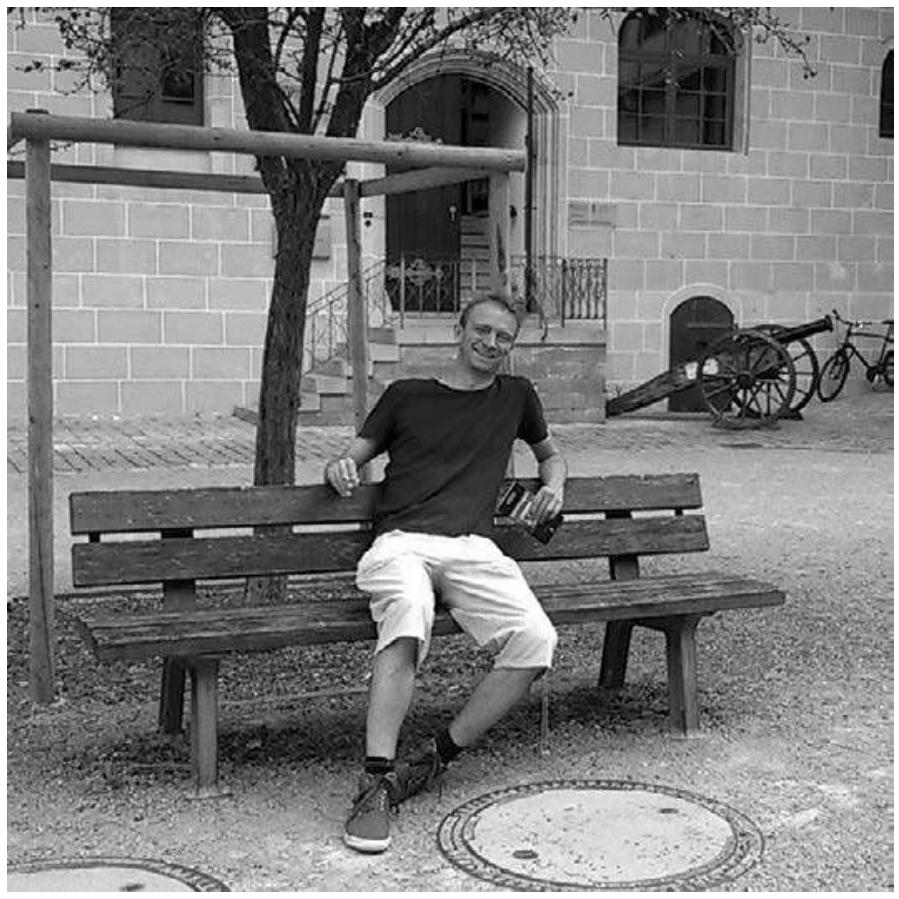

Aus dem sächsischen Theuma (Vogtland) stammend absolvierte Patrick Pfeil zunächst ein Magisterstudium der Altorientalistik, Alten Geschichte und Ägyptologie an der Universität Leipzig, das er mit einer Magisterarbeit zum 
Thema „Der Martu-Hymnus A“ abschloss. Im Anschluss begann er eine Promotion in Alter Geschichte an der Universität Leipzig bei Prof. Dr. Reinhold Scholl zum Thema "Gratian - ein Kinderkaiser im Kräftespiel der Mächte“. Im Rahmen seiner weiteren Tätigkeit an der Uni Leipzig war Patrick wissenschaftliche Hilfskraft und Mitarbeiter in verschiedenen Projekten im Bereich der Digital Humanities, u. a. hat er an dem Projekt eAQUA und dem Aufbau des gleichnamigen Portals mitgewirkt. Zudem war er von 2014-2018 Leiter des Lehrpraxis im Transfer-Facharbeitskreises Digital Humanities in Sachsen. Seit dem letzten Jahr war er wissenschaftlicher Mitarbeiter im DFG-Projekt Herrscherkult und Herrscherrepräsentation. Als Koordinator der Doktorand/innenklasse Kultureller Austausch der Research Academy Leipzig engagierte er sich zudem um die Weiterbildung des akademischen Nachwuchses, was sich in zahlreichen Exkursionen, Workshops und Tagungen niederschlug. Eine ganze Reihe eigener wissenschaftlicher Beiträge in Zeitschriften und Sammelbänden belegen zudem seine Publikationstätigkeit.

Auch außerhalb der Universität fiel Patrick durch sein großes persönliches Engagement auf, das sich vor allem in seiner ehrenamtlichen Tätigkeit niederschlug. So war er langjähriges aktives Mitglied der Jusos (Jugendorganisation der SPD) und in verschiedenen Positionen (zuletzt Präsident) in seinem Heimatverein SV Theuma e.V. tätig. Unvergessen wird auch seine Mitwirkung im Mitteldeutschen Altertumswissenschafts- und Sportverein bleiben, in deren Folge er ein sportliches Großereignis - den Winckelmann-Cup 2018 - mit ca. 700 wissenschaftlichen Kollegen aus den Altertumswissenschaften mitorganisierte.

Seine Offenheit, Freundlichkeit sowie sein Organisationstalent und seine Begeisterungsfähigkeit wurden von seinen Mitmenschen immer geschätzt. Er hinterlässt in unseren Reihen eine große Lücke. Wir alle trauern mit seiner Familie und sind in dieser schweren Zeit mit unseren Gedanken bei ihnen. 
Open-Access-Publikation im Sinne der CC-Lizenz BY-SA 4.0 ๑ 2020 , Vandenhoeck \& Ruprecht GmbH \& Co. KG, Göttingen ISBN Print: 9783847111771 - ISBN E-Lib: 9783737011778 
Open-Access-Publikation im Sinne der CC-Lizenz BY-SA 4.0 ๑ 2020 , Vandenhoeck \& Ruprecht GmbH \& Co. KG, Göttingen ISBN Print: 9783847111771 - ISBN E-Lib: 9783737011778 